Prepared in cooperation with the City of Aurora, Colorado, Utilities Department

\title{
Streamflow and Water-Quality Conditions Including Geologic Sources and Processes Affecting Selenium Loading in the Toll Gate Creek Watershed, Aurora, Arapahoe County, Colorado, 2007
}

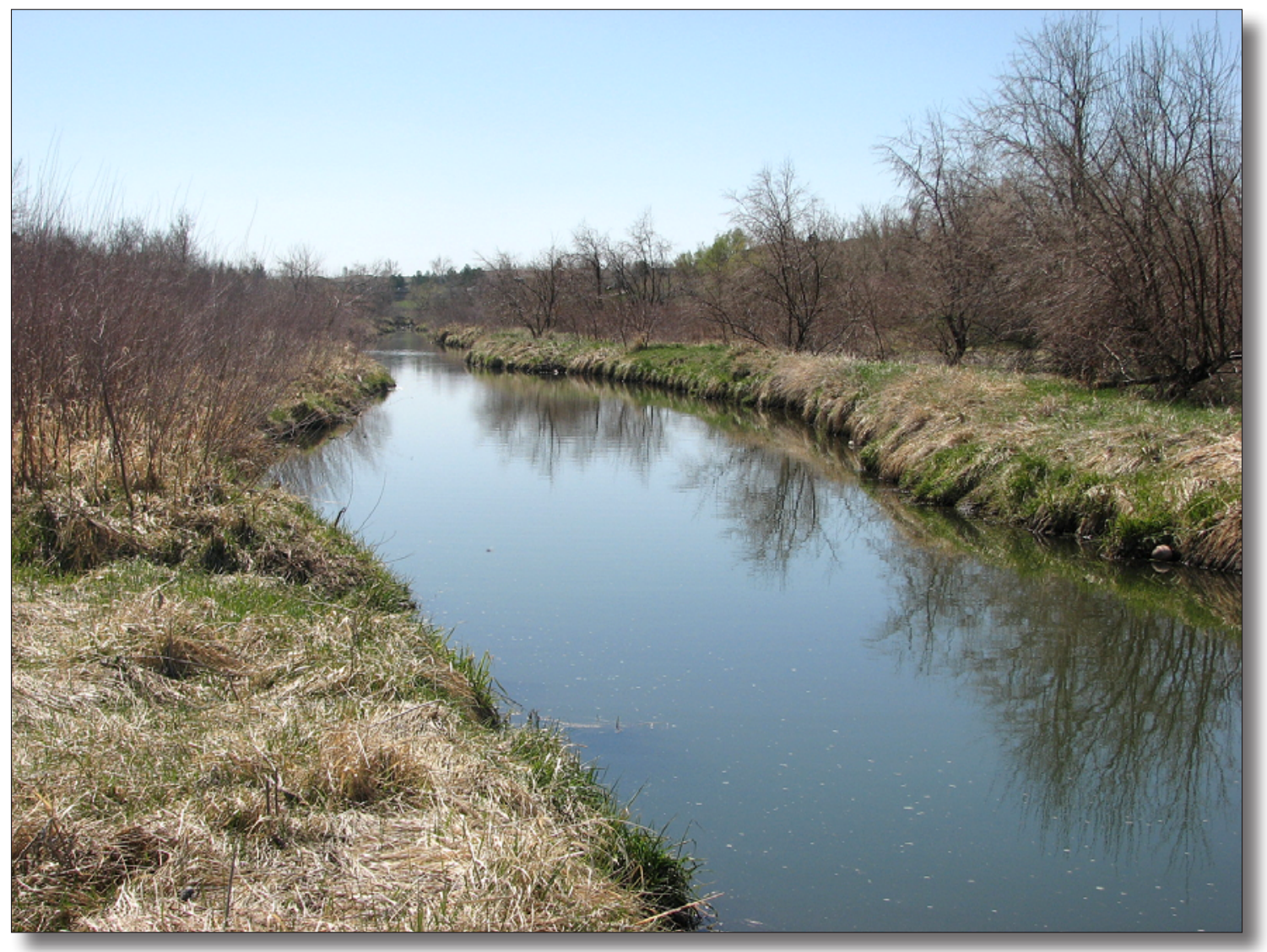

Scientific Investigations Report 2012-5280 
Cover: West Toll Gate Creek downstream from Mexico Avenue, Aurora, Colorado, April 2007 (Photograph by Suzanne Paschke). 


\section{Streamflow and Water-Quality Conditions Including Geologic Sources and Processes Affecting Selenium Loading in the Toll Gate Creek Watershed, Aurora, Arapahoe County, Colorado, 2007}

By Suzanne S. Paschke, Robert L. Runkel, Katherine Walton-Day, Briant A. Kimball, and Keelin R. Schaffrath

Prepared in cooperation with the City of Aurora, Colorado, Utilities Department

Scientific Investigations Report 2012-5280 


\title{
U.S. Department of the Interior SALLY JEWELL, Secretary
}

\section{U.S. Geological Survey Suzette M. Kimball, Acting Director}

\author{
U.S. Geological Survey, Reston, Virginia: 2013
}

For more information on the USGS - the Federal source for science about the Earth, its natural and living resources, natural hazards, and the environment, visit http://www.usgs.gov or call 1-888-ASK-USGS.

For an overview of USGS information products, including maps, imagery, and publications, visit http://www.usgs.gov/pubprod

To order this and other USGS information products, visit http://store.usgs.gov

Any use of trade, firm, or product names is for descriptive purposes only and does not imply endorsement by the U.S. Government.

Although this information product, for the most part, is in the public domain, it also may contain copyrighted materials as noted in the text. Permission to reproduce copyrighted items must be secured from the copyright owner.

Suggested citation:

Paschke, S.S., Runkel, R.L., Walton-Day, Katherine, Kimball, B.A., Schaffrath, K.R., 2013, Streamflow and waterquality conditions including geologic sources and processes affecting selenium loading in the Toll Gate Creek watershed, Aurora, Arapahoe County, Colorado, 2007: U.S. Geological Survey Scientific Investigations Report 2012-5280, 108 p., http://pubs.usgs.gov/sir/2012/5280/. 


\section{Contents}

Abstract
Introduction
Purpose and Scope
Selenium Occurrence and Geochemistry
Study Area Description
Physiography Use
Surface-Water Hydrology
Geology and Groundwater Hydrology

Synoptic-Sampling and Tracer-Injection Background .........................................................17

Toll Gate Creek Stream Reaches and Sampling Sequence of Events ....................................18

Synoptic Sampling and Tracer Injections.......................................................................19

Surface-Water Sample Processing and Analytical Methods ...............................................19

Surface-Water Mass-Loading Calculations...........................................................................

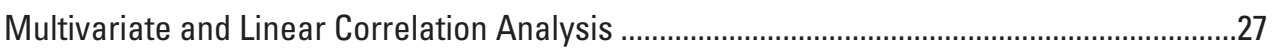

Groundwater Sample Collection, Processing, and Analytical Methods ..................................28

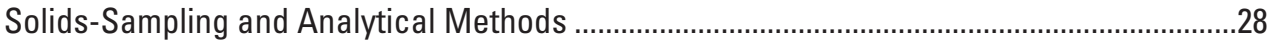

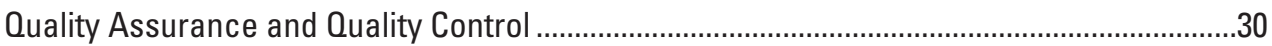

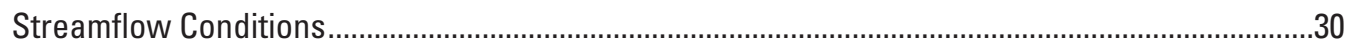

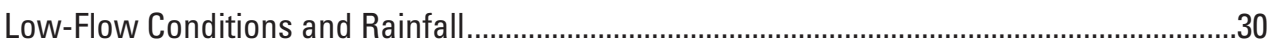

Effects of Increased Streamflow on Constituent Concentrations...........................................30

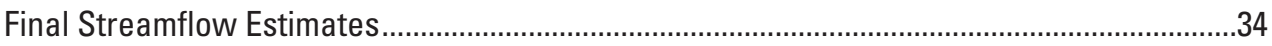

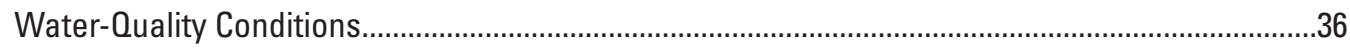

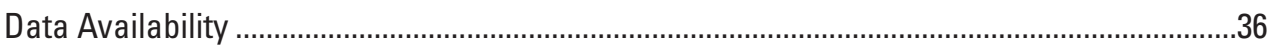

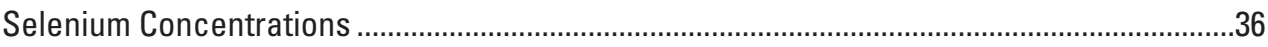

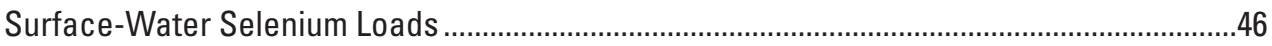

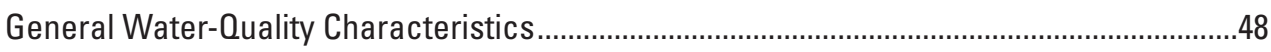

Total Dissolved Solids and Major-Ion Chemistry........................................................49

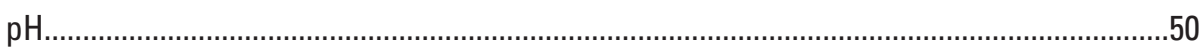

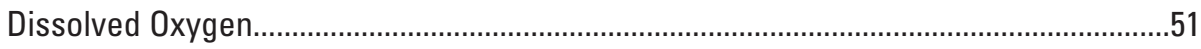

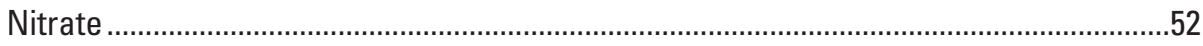

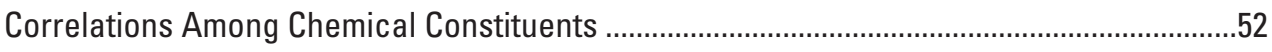

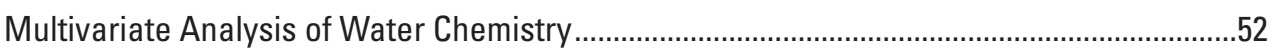

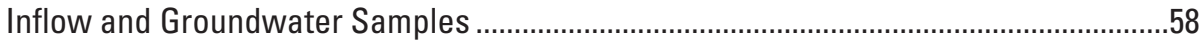

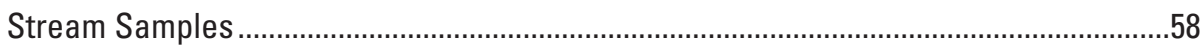

Hydrogen- and Oxygen-Isotope Ratios as Indicators of Evaporation ......................................63

Apparent Groundwater Ages and Recharge Rates ..........................................................65

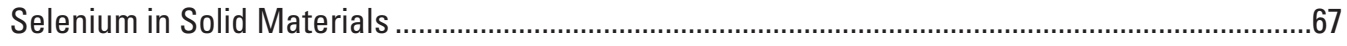

Geologic Sources and Processes Affecting Selenium Loading ..................................................67

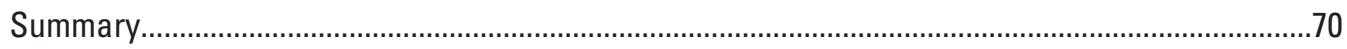

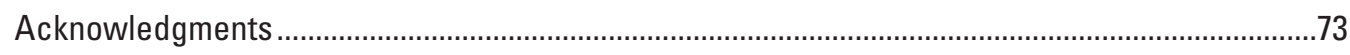

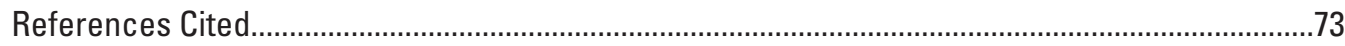




\section{Appendixes}

Appendix 1. Development of Streamflow Estimates

Appendix 2. Analytical Quality-Assurance and Quality-Control Data and Results for

Toll Gate Creek Surface-Water and Groundwater Samples, 2007

Appendix 3. Concentration and Loading Profiles for Constituents of Interest other than Selenium

Appendix 4. Calculations of Evaporative Concentration and Loss

\section{Figures}

1. Map showing extent of Cretaceous shale in Colorado, Denver Basin, seleniumimpaired streams on the Colorado 303(d) list in 2006, and location of study area.............3

2. Map showing land-surface altitude and location of synoptic-sampling study reach, Toll Gate Creek watershed, Aurora, Colorado

3. Map showing extent of urbanization since 1948 in the Toll Gate Creek watershed, Aurora, Colorado

4. Map showing location of synoptic-sampling subreaches, surface-water sampling sites, groundwater monitoring wells, and the 6th Avenue stream gage (USGS gaging station 394329104490101), Toll Gate Creek, July-August 2007

5. Photograph showing West Toll Gate Creek looking upstream from Mansfield Avenue toward Quincy Reservoir, Aurora, Colorado, July 2007 (Photograph by Suzanne Paschke).

6. Photograph showing West Toll Gate Creek looking upstream beneath the Hampden Avenue bridge where stream enters the concrete-lined channel, Aurora, Colorado, July 2007 (Photograph by Suzanne Paschke)

7. Photograph showing West Toll Gate Creek concrete-lined channel looking downstream toward Buckley Road, Aurora, Colorado, July 2007 (Photograph by Suzanne Paschke)

8. Photograph showing drop structure along West Toll Gate Creek downstream from Mexico Avenue, Aurora, Colorado, July 2007 (Photograph by Robert Runkel)

9. Photograph showing West Toll Gate Creek downstream from Mexico Avenue, Aurora, Colorado, April 2007 (Photograph by Suzanne Paschke)

10. Photograph showing Toll Gate Creek (on left) and Sand Creek (on right) confluence. View looking downstream toward confluence, Aurora, Colorado, April 2007 (Photograph by Suzanne Paschke)

11. Map showing Denver Formation outcrop and water-table altitude contours, Toll Gate Creek, Aurora, Colorado (after Robson, 1996)

12. Photograph showing tonstein within and secondary evaporative deposits on surface of claystone bedrock outcrop along Toll Gate Creek streambank, Aurora, Colorado, July 2007 (Photograph by Suzanne Paschke)...

13. Graph showing Toll Gate Creek stream stage at the 6th Avenue stream gage (U.S. Geological Survey stream-gaging station 394329104490101), March-September 2007

14. Graph showing Toll Gate Creek stream stage at the 6th Avenue stream gage (U.S. Geological Survey stream-gaging station 394329104490101) showing sequence of stream field activities and periods of tracer injection, July-August 2007 
15. Graph showing Toll Gate Creek stream stage at the 6th Avenue stream gage

(U.S. Geological Survey stream-gaging station 394329104490101) during

tracer-injection and synoptic-sampling periods. Stream stage during synoptic-sampling periods is shown as a thick line and indicates synoptic

sampling occurred during surface-water flow recession.

16. Graph showing relation between stream stage and specific conductance at the

6th Avenue stream gage (U.S. Geological Survey stream-gaging station

394329104490101) during Toll Gate Creek middle subreach synoptic sampling, July 29, 2007.

17. Graph showing final stream stage estimates related to distance downstream from

Quincy Reservoir, Toll Gate Creek, July-August 2007

18. Graph showing dissolved stream selenium concentrations related to distance downstream from Quincy Reservoir, Toll Gate Creek, July-August 2007.

19. Graph showing dissolved stream and inflow selenium concentrations related to distance downstream from Quincy Reservoir, Toll Gate Creek, July-August 2007

20. Photograph showing left-bank inflow TG-2165, groundwater discharge along the contact between surficial materials and underlying claystone bedrock, March 2008. (Photograph by Suzanne Paschke).

21. Photograph showing right-bank inflow TG-10557, groundwater discharge along the contact between surficial materials and underlying claystone bedrock, July 2008 (Photograph by Suzanne Paschke).

22. Boxplot showing distribution of dissolved selenium concentrations, in micrograms per liter, for groundwater, inflow, and stream samples, Toll Gate Creek, July-August 2007. Sample names indicated for groundwater upper outliers

23. Map showing dissolved selenium concentrations in groundwater, springs, and the eleven inflows with the greatest selenium concentrations from synoptic sampling, Toll Gate Creek, July-August 2007.

24. Graph showing dissolved selenium instream load in relation to distance downstream from Quincy Reservoir, Toll Gate Creek, July-August 2007.

25. Boxplot showing distribution of total dissolved solids concentrations, in milligrams per liter, for groundwater, inflow, and stream samples, Toll Gate Creek, July-August 2007. Site names indicated for groundwater upper outliers

26. Trilinear plot showing percentages of major cations and anions, in milliequivalents per liter, for groundwater, inflow, and stream samples, Toll Gate Creek, July-August 2007.

27. Boxplot showing distribution of $\mathrm{pH}$ values, in standard units, for groundwater, inflow, and stream samples, Toll Gate Creek, July-August 2007.

28. Boxplot showing distribution of dissolved nitrate (nitrite plus nitrate) concentrations as nitrogen, in milligrams per liter, in groundwater, inflow, and stream samples, Toll Gate Creek, Colorado, July-August 2007.

29. Graphs showing dissolved $A$, selenium and $B$, sulfate concentrations related to distance downstream from Quincy Reservoir, and cluster analysis results for stream and inflow samples, Toll Gate Creek, July-August 2007..

30. Graphs showing variation of $A$, sodium, $B$, bromide, $C$, selenium, and $D$, uranium concentrations with sulfate concentration, and cluster-analysis results (inflow and groundwater groups derived from cluster analysis) for surface-water inflows and groundwater along the study reach, Toll Gate Creek, July-August 2007.

31. Graph showing elation of dissolved selenium and sulfate concentration, and cluster-analysis results (stream groups derived from cluster analysis in table 12) for stream samples, Toll Gate Creek, July-August 2007. 
32. Graph showing variation of manganese concentration with distance downstream from Quincy Reservoir, and cluster analysis results (Stream and Inflow groups defined on table 12 and table 11) for stream and inflow samples along the study reach, Toll Gate Creek, Aurora, Colorado, July-August 2007.

33. Graph showing global meteoric water line, local meteoric water line, and $\delta^{2} \mathrm{H}$ related to $\delta^{18} 0$ ratios and total dissolved solids concentration for groundwater, inflow, and stream samples, Toll Gate Creek, July-August 2007. Total dissolved solids symbols are continuously scaled. Several sizes are shown for reference in the explanation

34. Graph showing water-extractable selenium concentration in core in relation to depth below land surface for well ET-1

35. Conceptual diagram of selenium occurrence in the Toll Gate Creek watershed ............69

1-1. Graph showing acoustic Doppler Velocity meter streamflow measurements and linear regression lines for alternative streamflow estimates, Toll Gate Creek, July-August 2007 (Regression lines defined in table 1-3)

2-1. Graphs showing spiked-standard concentrations for surface-water samples, Toll Gate Creek, July-August 2007.

3-1. Graph showing dissolved sodium concentrations for stream and inflow samples compared to distance downstream from Quincy Reservoir, Toll Gate Creek, July-August 2007

3-2. Graph showing dissolved sulfate concentrations for stream and inflow samples compared to distance downstream from Quincy Reservoir, Toll Gate Creek, July-August 2007.

3-3. Graph showing dissolved uranium concentrations for stream and inflow samples compared to distance downstream from Quincy Reservoir, Toll Gate Creek, July-August 2007

3-4. Graph showing dissolved sodium stream load compared to distance downstream from Quincy Reservoir, Toll Gate Creek, July-August 2007.

3-5. Graph showing dissolved sulfate stream load compared to distance downstream from Quincy Reservoir, Toll Gate Creek, July-August 2007.

3-6. Graph showing dissolved uranium stream load compared to distance downstream from Quincy Reservoir, Toll Gate Creek, July-August 2007

\section{Tables}

1. Toll Gate Creek synoptic surface-water sampling, tracer injection, and groundwater sampling sequence of events, 2007.

2. Site information for stream and inflow synoptic-sampling sites, Toll Gate Creek, July-August 2007

3. Water-quality constituents analyzed for surface-water and groundwater samples, Toll Gate Creek, July-August 2007.

4. Location and completion information for sampled groundwater monitoring wells, Toll Gate Creek, July-August 2007.

5. Selected analytical results for synoptic surface-water samples, Toll Gate Creek, July-August 2007

6. Selected analytical results for groundwater samples, Toll Gate Creek, July-August 2007

7. Site information for 11 inflow sites with greatest dissolved selenium concentration, Toll Gate Creek, July-August 2007. 
8. Tritium, dissolved-gas, and chlorofluorocarbon concentrations, apparent groundwater ages, and apparent recharge rates for selected groundwater samples, Toll Gate Creek, July-August 2007.

9. Linear correlation coefficients for dissolved constituents in stream samples, Toll Gate Creek, July-August 2007.

10. Linear correlation coefficients for dissolved constituents in groundwater samples, Toll Gate Creek, July-August 2007.

11. Representative samples from each of the inflow groups defined by cluster analysis, Toll Gate Creek, July-August 2007

12. Representative samples from stream groups defined by cluster analysis, Toll Gate Creek, July-August 2007

1-1. Summary of bromide concentrations, tracer-dilution estimates, and current-meter measurements used to develop final streamflow estimates, Toll Gate Creek, July-August 2007

1-2. Summary of hydrologic and tracer-injection information used to determine streamflow estimates and interpret results, Toll Gate Creek, July-August 2007

1-3. Development of alternative streamflow estimates, Toll Gate Creek, July-August 2007

2-1. Analytical quality-assurance and quality-control data for surface-water sampling blanks, Toll Gate Creek, July-August 2007

2-2. Analytical quality-assurance and quality-control data for groundwater sampling blanks, Toll Gate Creek, July-August 2007

2-3. Analytical quality-assurance and quality-control data for surface-water replicates, Toll Gate Creek, July-August 2007.

2-4. Analytical quality-assurance and quality-control data for groundwater replicates, Toll Gate Creek, July-August 2007.

2-5. Analytical quality-assurance and quality- control data for surface-water sample spikes, Toll Gate Creek, July-August 2007

4-1. Evaporative concentration calculations from oxygen-isotope ratios for groundwater, inflow, and stream samples, Toll Gate Creek, July-August 2007 


\section{Conversion Factors}

SI to Inch/Pound

\begin{tabular}{lcl}
\hline \multicolumn{1}{c}{ Multiply } & By & \multicolumn{1}{c}{ To obtain } \\
\hline micrometer $(\mu \mathrm{m})$ & Length & inch (in) \\
meter $(\mathrm{m})$ & 0.00003937 & foot $(\mathrm{ft})$ \\
kilometer $(\mathrm{km})$ & 3.281 & mile $(\mathrm{mi})$ \\
\hline & 0.6214 & \\
\hline kilometer $^{2}(\mathrm{~km})$ & Area & mile $^{2}\left(\mathrm{mi}^{2}\right)$ \\
\hline & 0.3861 & \\
\hline liter $(\mathrm{L})$ & Volume & gallon $(\mathrm{gal})$ \\
cubic meter $\left(\mathrm{m}^{3}\right)$ & 0.2642 & gallon $(\mathrm{gal})$ \\
cubic meter $\left(\mathrm{m}^{3}\right)$ & 264.2 & cubic foot $\left(\mathrm{ft}^{3}\right)$ \\
\hline & 35.31 & \\
\hline cubic meter per second $\left(\mathrm{m}^{3} / \mathrm{s}\right)$ & Flow rate & cubic feet per second $\left(\mathrm{ft}^{3} / \mathrm{s}\right)$ \\
liter per second $(\mathrm{L} / \mathrm{s})$ & 35.31 & gallon per minute $\left(\mathrm{gal} / \mathrm{min}^{3}\right)$ \\
\hline & 15.85 & pound, avoirdupois $(\mathrm{lb})$ \\
\hline kilogram $(\mathrm{kg})$ & Mass &
\end{tabular}

Temperature in degrees Celsius $\left({ }^{\circ} \mathrm{C}\right)$ may be converted to degrees Fahrenheit $\left({ }^{\circ} \mathrm{F}\right)$ as follows:

${ }^{\circ} \mathrm{F}=\left(1.8 x^{\circ} \mathrm{C}\right)+32$

Temperature in degrees Fahrenheit $\left({ }^{\circ} \mathrm{F}\right)$ may be converted to degrees Celsius $\left({ }^{\circ} \mathrm{C}\right)$ as follows:

${ }^{\circ} \mathrm{C}=\left({ }^{\circ} \mathrm{F}-32\right) / 1.8$

Horizontal coordinate information is referenced to the North American Datum of 1983 (NAD 83)

Specific conductance is given in microsiemens per centimeter at 25 degrees Celsius $(\mu \mathrm{S} / \mathrm{cm}$ at $\left.25^{\circ} \mathrm{C}\right)$.

Concentrations of chemical constituents in water are given either in milligrams per liter (mg/L) or micrograms per liter $(\mu \mathrm{g} / \mathrm{L})$.

\section{Abbreviations and Acronyms}

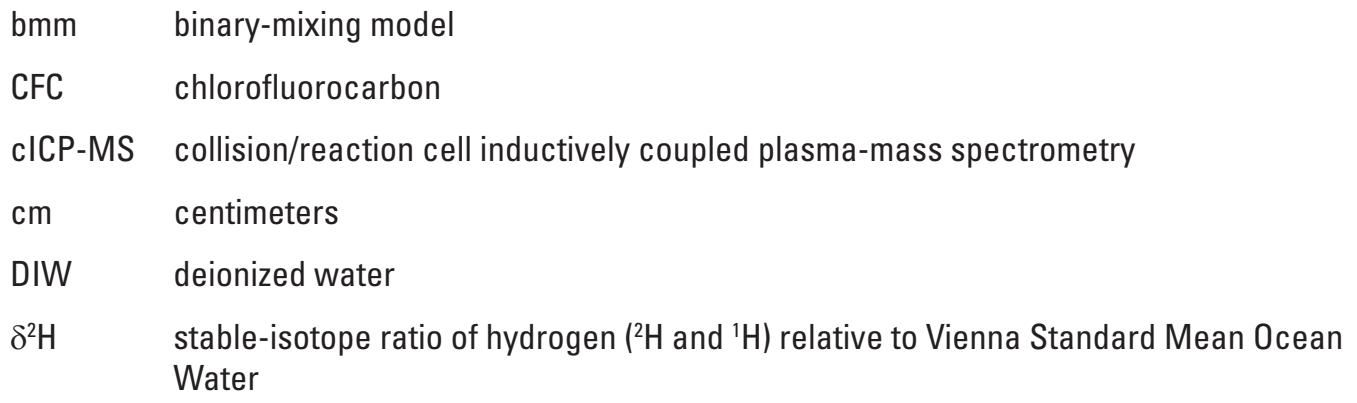

$\delta^{2} \mathrm{H} \quad$ stable-isotope ratio of hydrogen $\left({ }^{2} \mathrm{H}\right.$ and $\left.{ }^{1} \mathrm{H}\right)$ relative to Vienna Standard Mean Ocean Water 


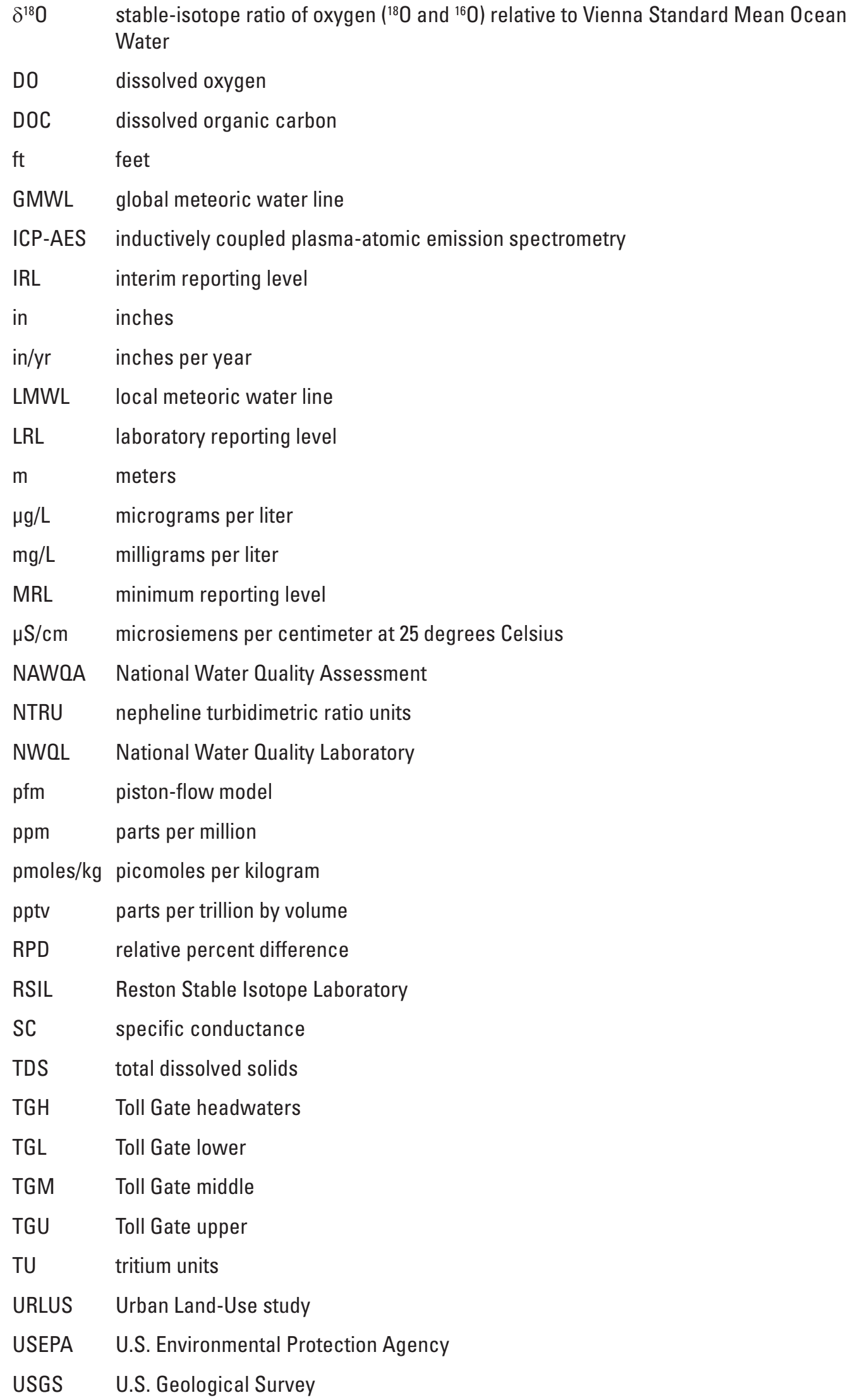





\title{
Streamflow and Water-Quality Conditions Including Geologic Sources and Processes Affecting Selenium Loading in the Toll Gate Creek Watershed, Aurora, Arapahoe County, Colorado, 2007
}

\author{
By Suzanne S. Paschke, Robert L. Runkel, Katherine Walton-Day, Briant A. Kimball, and Keelin R. Schaffrath
}

\section{Abstract}

Toll Gate Creek is a perennial stream draining a suburban area in Aurora, Colorado, where selenium concentrations have consistently exceeded the State of Colorado aquatic-life standard for selenium of 4.6 micrograms per liter since the early 2000s. In cooperation with the City of Aurora, Colorado, Utilities Department, a synoptic water-quality study was performed along an 18-kilometer reach of Toll Gate Creek extending from downstream from Quincy Reservoir to the confluence with Sand Creek to develop a detailed understanding of streamflow and concentrations and loads of selenium in Toll Gate Creek. Streamflow and surface-water quality were characterized for summer low-flow conditions (July-August 2007) using four spatially overlapping synopticsampling subreaches. Mass-balance methods were applied to the synoptic-sampling and tracer-injection results to estimate streamflow and develop spatial profiles of concentration and load for selenium and other chemical constituents in Toll Gate Creek surface water. Concurrent groundwater sampling determined concentrations of selenium and other chemical constituents in groundwater in areas surrounding the Toll Gate Creek study reaches. Multivariate principal-component analysis was used to group samples and to suggest common sources for dissolved selenium and major ions. Hydrogen and oxygen stable-isotope ratios, groundwater-age interpretations, and chemical analysis of water-soluble paste extractions from core samples are presented, and interpretation of the hydrologic and geochemical data support conclusions regarding geologic sources of selenium and the processes affecting selenium loading in the Toll Gate Creek watershed.

Streamflow conditions observed and measured during the synoptic water-quality study represent summer base-flow conditions and rainfall conditions for July 2007. The final streamflow profile for July 2007 provides evidence that streamflow increases steadily within each subreach and for the entire study reach, indicating that Toll Gate Creek is a gaining stream. The lack of large tributary inflows and the spatial distribution of small tributary inflows, seeps, and springs indicate that diffuse and discrete groundwater inflow supports streamflow during low-flow conditions along the entire 18-kilometer stream reach. Streamflow in the Toll Gate Middle (TGM) subreach was substantially greater than that in the other subreaches because of rainfall. Streamflow in the TGM subreach increased rapidly in response to the rainfall as would be expected in a suburban setting where paved areas and channelization increase surfacewater runoff and decrease runoff transit time to local drainages compared to undeveloped areas.

Concentrations of dissolved selenium within all subreaches of Toll Gate Creek exceeded the Colorado aquatic-life standard of 4.6 micrograms per liter in 2007. Concentrations of selenium in the upper portion of the Toll Gate Headwaters subreach (TGH) remained close to the aquatic-life standard at about 5 micrograms per liter. Wetlands in the upper TGH create reducing conditions where selenium can be reduced to insoluble forms and removed from the water column. Downstream from the wetland reach is a concrete-lined channel that likely prevents groundwater and thus selenium discharge to the stream, and selenium concentrations are at about 5 micrograms per liter. Downstream from the concrete-lined channel, inflows with selenium concentrations greater than the stream contribute selenium load to surface water. However, stream selenium concentrations were less than 20 micrograms per liter all along Toll Gate Creek. Concentrations of selenium were diluted to less than 10 micrograms per liter for the TGM subreach because of rainfall that occurred prior to synoptic sampling. Of the 32 discrete sampled inflows, selenium concentrations in 11 inflows were greater than 21 micrograms per liter. Selenium concentrations at the remaining 21 inflows were less than 12 micrograms per liter. Nine of the 11 inflows with the greatest selenium concentrations emanate from culverts, which are channelized tributaries and storm drains that collect surface-water runoff and groundwater discharge. Two of the 11 inflows are springs along the contact between bedrock and overlying alluvial materials where groundwater flows directly to the stream. Concentrations of selenium in groundwater were in general substantially greater than the Colorado aquatic-life standard of 4.6 micrograms per liter and at some locations were greater than the U.S. Environmental Protection Agency primary 
drinking-water standard for selenium of 50 micrograms per liter. The distribution of selenium concentrations in groundwater, springs, and the 11 inflows with the greatest selenium concentrations indicates that shallow groundwater in surficial materials and the Denver Formation bedrock is a source of selenium loading to Toll Gate Creek and that selenium loading is distributed along the entire length of the study reach downstream from the concrete-lined channel at Buckley Road.

General water quality in the Toll Gate Creek watershed is characterized by total dissolved solids concentrations that frequently exceed the U.S. Environmental Protection Agency secondary drinking-water standard of 500 milligrams per liter, near neutral to slightly alkaline $\mathrm{pH}$ conditions, a wide range of reduction and oxidation (redox) conditions, detections of nitrate in groundwater, hydrogen-oxygen isotope ratios indicative of active evaporative processes, and apparent groundwater-age interpretations of primarily young water recharged since the 1960s. Strong linear statistical correlations among selenium and other dissolved constituents indicate that the correlated constituents are derived from the same or related geologic sources. Concentrations of selenium and major-ions in groundwater in combination with oxygen-isotopic results and apparent groundwater ages indicate water-rock interaction, evaporation, and possibly nitrate reduction processes are affecting concentrations of selenium in groundwater. At the two wells with the greatest selenium concentrations, a component of old groundwater is indicated by low tritium concentrations, and water-rock interaction over long groundwater-residence times, on the order of 50 years or longer, is considered a primary process affecting concentrations of selenium in groundwater. Oxygen-isotope results indicate evaporative loss in the semiarid climate also contributes to concentrating selenium and major ions in groundwater; however, evaporation is considered a secondary process because evaporative loss cannot fully account for the observed concentrations of selenium and total dissolved solids.

Water-quality and solids-sampling results from this study indicate weathering processes release water-soluble selenium from the underlying Denver Formation claystone bedrock with subsequent cycling of selenium in the aquatic environment of Toll Gate Creek. Exposure of the Denver Formation selenium-bearing bedrock to oxidizing atmospheric conditions, surface water, and groundwater, oxidizes selenide, held as a trace element in pyrite or in complexes with organic matter, to selenite and selenate. Secondary weathering products including iron oxides and selenium-bearing salts have accumulated in the weathered zone in the semiarid climate and also can serve as sources or sinks of selenium. Presentday selenium-bearing evaporative salts observed along streambanks concentrate selenium from underlying bedrock and sediments and another source of selenium to Toll Gate Creek surface water. These evaporative deposits are rapidly dissolved during high streamflow events contributing selenium and total dissolved solids to Toll Gate Creek. Concentrations of selenium and major ions exhibited less variability in surface water than concentrations in inflow or groundwater indicating that hydrological, geochemical, and biological instream processes were effectively mixing the inflow and groundwater discharge received by the stream. In addition, plant uptake was likely attenuating selenium and nitrate concentrations in surface water during the summer low-flow study period.

\section{Introduction}

Selenium is a trace element essential to humans and animals; however, elevated concentrations of selenium can be toxic to humans, fish, and wildlife (Stadtman, 1974; Gissel-Nielson and others, 1984). In the aquatic environment, selenium in the water column can accumulate through the food chain leading to elevated selenium concentrations in tissues of fish and birds (Lemly, 1985; Ohlendorf and others, 1986; Ohlendorf, 1989; Presser, 1994). Toxic effects of selenium on fish and birds can include mortality, decreased reproduction, and deformities in offspring (Ohlendorf and others, 1986; Presser and Ohlendorf, 1987; Ohlendorf, 1989). The U.S. Environmental Protection Agency (USEPA) established a primary drinking-water standard for selenium of 50 micrograms per liter $(\mu \mathrm{g} / \mathrm{L})$ (U.S. Environmental Protection Agency, 2003) and, in 1997, the State of Colorado established an aquatic-life standard for selenium of $4.6 \mu \mathrm{g} / \mathrm{L}$ (Colorado Department of Public Health and Environment, 2008). Statewide in Colorado, numerous streams are included on the Colorado list of impaired waters under provisions of Section 303(d) of the Clean Water Act of 1972 (303(d) list) because concentrations of dissolved selenium exceed the aquatic-life standard of $4.6 \mu \mathrm{g} / \mathrm{L}$ (fig. 1).

Many selenium-impaired streams in Colorado are associated with nonpoint-source groundwater discharge and selenium loading from areas underlain by Cretaceous marine shale (fig. 1). Both the Cretaceous Mancos Shale in western Colorado and its equivalent, the Cretaceous Pierre Shale, in central and eastern Colorado are known sources of selenium. In the Toll Gate Creek watershed examined by this study, near-surface bedrock consists of interbedded nonmarine claystones, sandstones, lignites, and volcanic deposits of the Cretaceous- to Tertiaryaged Denver Formation (Robson and Romero, 1981). Claystone and lignite deposits containing ash and sediment from volcanic origins, such as the Denver Formation, can contain elevated selenium (Kulp and Pratt, 2004; Neuzil and others, 2005, Fernández-Martinez and Charlet, 2009), and the Denver Formation is the likely geologic source of selenium to shallow groundwater and surface water in the Toll Gate Creek watershed. The Cretaceous Pierre Shale occurs at an approximate depth of about 550 meters (m) below land surface (Paschke, 2011) and is not the likely source of selenium in Toll Gate Creek.

Concentrations of dissolved selenium in Toll Gate Creek of Aurora, Colo., have consistently exceeded the Colorado aquatic-life standard of $4.6 \mu \mathrm{g} / \mathrm{L}$ since the early 2000s (Brown and Caldwell and Chadwick Ecological Consultants, 2003; Herring and Walton-Day, 2007). Toll Gate Creek is a perennial 


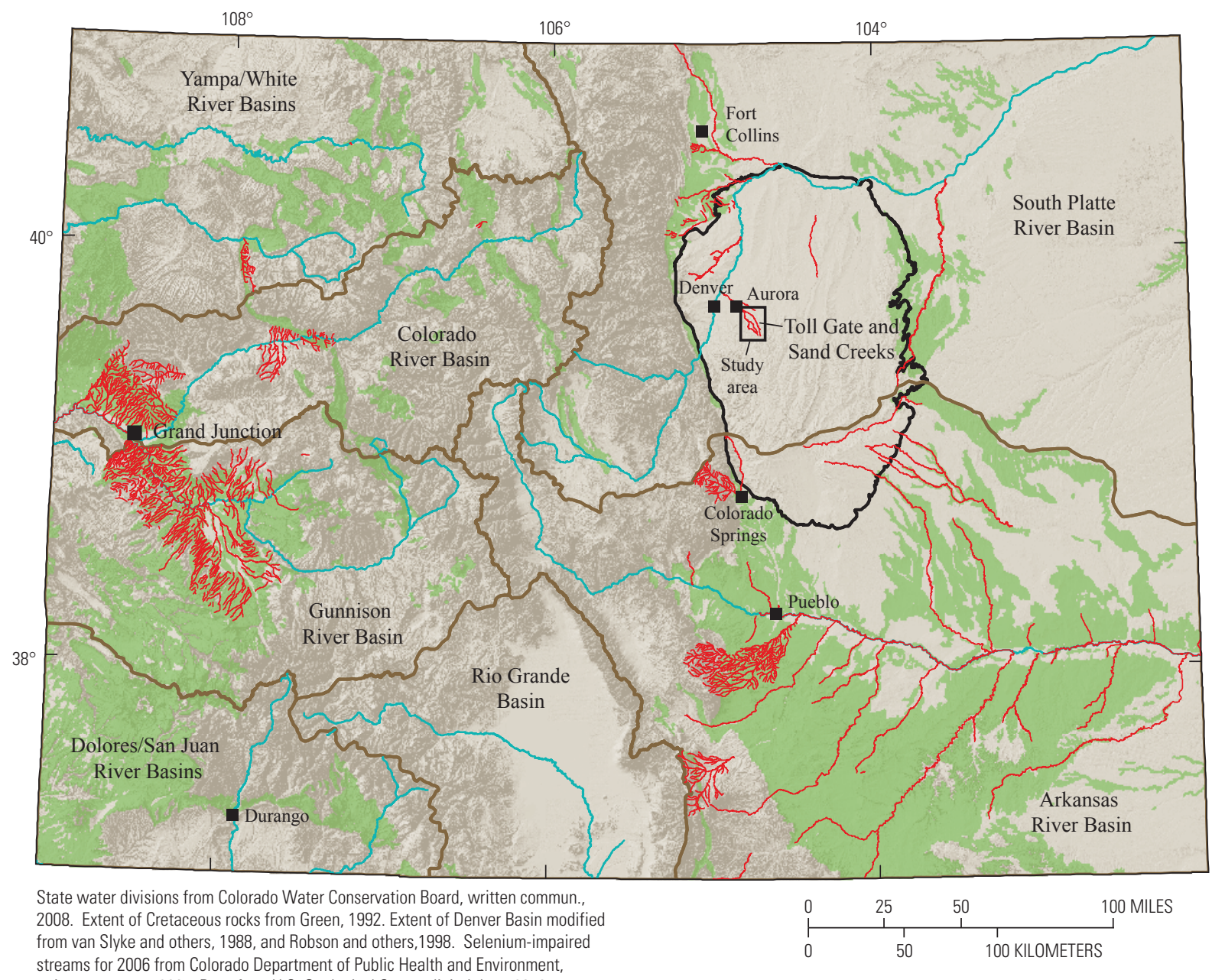

streams for 2006 from Colorado Department of Public Health and Environment,

written commun., 2007. Base from U.S. Geological Survey digital data, 2012

\section{EXPLANATION}
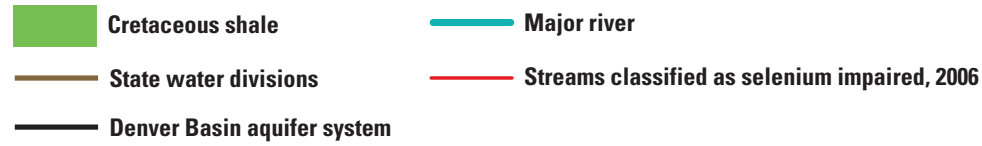

Figure 1. Map showing extent of Cretaceous shale in Colorado, Denver Basin, selenium-impaired streams on the Colorado 303(d) list in 2006, and location of study area.

plains stream that drains a suburban area within the City of Aurora, Colo., where surface water is derived from local rainfall and snowmelt (surface-water) runoff, urban storm drainage, and groundwater discharge from the encompassing watershed. No known point discharges to the stream exist that could account for the observed selenium concentrations. Previous work indicates that greater than 85 percent of the selenium loading to Toll Gate Creek originates from the tributary of West Toll Gate Creek, and groundwater discharge to the stream was considered as the source of selenium to Toll Gate Creek (Herring and Walton-Day, 2007). Previous hydrogeologic maps of the watershed (Robson, 1996) depict a variably saturated water-table groundwater system in the Quaternary surficial materials and top of the underlying Denver Formation with groundwater flow toward Toll Gate Creek and its tributaries.
In addition, groundwater-quality data from the U.S. Geological Survey (USGS; http://waterdata.usgs.gov/nwis/, accessed August 28, 2008) indicate the presence of dissolved selenium concentrations at the water table in the vicinity of Toll Gate Creek for samples collected in 2003. These observations provided evidence that selenium concentrations in Toll Gate Creek are the result of water-rock interaction among groundwater, surface water, and the selenium-bearing bedrock of the Denver Formation, with subsequent flow and discharge to Toll Gate Creek. The U.S. Geological Survey, in cooperation with the City of Aurora, Colorado, Utilities Department, conducted this study of Toll Gate Creek in late July and early August 2007 to further characterize streamflow and water-quality conditions including geologic sources and processes affecting selenium loading in the Toll Gate Creek watershed for low-flow conditions. 
Streamflow and Water-Quality Conditions in the Toll Gate Creek Watershed, Aurora, Arapahoe County, Colorado, 2007

\section{Purpose and Scope}

The purpose of this report is to describe and interpret streamflow and water-quality conditions including geologic sources and processes affecting selenium loading in the Toll Gate Creek watershed for summer low-flow conditions in 2007. The 18-kilometer $(\mathrm{km})$ reach of Toll Gate Creek extending from downstream from Quincy Reservoir to the confluence with Sand Creek was assessed using four spatially overlapping synoptic-sampling subreaches. Field reconnaissance identified all inflows for the $18-\mathrm{km}$ reach of Toll Gate Creek, and its tributary West Toll Gate Creek, and a series of synoptic-sampling and tracer-injection events were employed to assess selenium loading to the stream. Mass-balance methods were applied to the synopticsampling and tracer-injection results to estimate streamflow and develop spatial profiles of concentration and load for selenium and other chemical constituents in Toll Gate Creek surface water. Concurrent groundwater sampling determined concentrations of selenium and other chemical constituents in groundwater in areas surrounding the Toll Gate Creek study reaches. Multivariate principal-component analysis was used to group samples and to suggest common sources for selenium and other dissolved constituents. Results for hydrogen and oxygen stable-isotope ratios, groundwater-age interpretations, and chemical analyses of water-soluble paste extractions from core samples are presented, and interpretation of the hydrologic and geochemical data support conclusions regarding the geologic sources and processes affecting selenium loading in the Toll Gate Creek watershed.

\section{Selenium Occurrence and Geochemistry}

Many rocks and minerals are selenium bearing, and weathering of these rocks is the major natural source of selenium in the aquatic environment (McNeal and Balistrieri, 1989). Chemical reactions that occur during weathering such as mineral dissolution and precipitation, chemical adsorption and desorption, evaporative concentration, and biological uptake and release all can control selenium concentrations and transport in the aquatic environment (McNeal and Balistrieri, 1989). Selenium can exist at four different oxidation states such that reduction and oxidation (redox) conditions and chemical reactions affect selenium speciation, mobility, and bioavailability in the aquatic environment (McNeal and Balistrieri, 1989).

Organic-rich fine-grained sediments including coal tend to have high selenium concentrations (Adriano, 2001), on the order of 0.5 to 11 milligrams per kilogram (mg/ $\mathrm{kg}$ ), because of the presence of included volcanic ash layers (Kulp and Pratt, 2004; Neuzil and others, 2005), seleniumbearing sulfide minerals, or the complexation of selenium with organic matter (McNeal and Balistrieri, 1989; Yudovich and Ketris, 2006). Large selenium contents are common in sedimentary rocks associated with coal in the western United States (Lakin, 1961), and selenium is considered one of the most enriched trace elements in coal because of its affinity to organic carbon. (Gluskoter and others, 1977; Valkovic, 1983; Coleman and others, 1993; Neuzil and others, 2005). Selenium also is associated with volcanic activity and volcanic deposits are sources of selenium. (Sindeeva, 1964; Malisa, 2001; Witham and others, 2004). Sedimentary rocks with volcanic input, such as bentonite claystones containing tonsteins and volcanic ash, also frequently exhibit high selenium concentrations (Davidson and Powers, 1959; Kulp and Pratt, 2004). In addition to selenium, volcanic ash deposits contain calcium, magnesium, sodium, sulfate, chloride, bromide, and uranium that can form soluble salts upon weathering (Witham and others, 2004).

The chemistry of selenium resembles that of sulfur and, like sulfur, selenium can exist at four different oxidation states: (1) 2- ( $\mathrm{Se}^{2-}$, selenide), (2) 0 ( $\mathrm{Se}^{0}$, elemental selenium), (3) $4+\left(\mathrm{SeO}_{3}{ }^{2-}\right.$, selenite oxyanion), and (4) $6+\left(\mathrm{SeO}_{4}{ }^{2-}\right.$, selenate oxyanion) (McNeal and Balistrieri, 1989). Selenium oxidation states depend on $\mathrm{pH}$ and redox conditions, which frequently are controlled by biological reactions with microorganisms (McNeal and Balistrieri, 1989; FernándezMartinez and Charlet, 2009). Each oxidation state exhibits different chemical behavior that determines mobility and thus bioavailability in the aquatic environment (McNeal and Balistrieri, 1989; Fernández-Martinez and Charlet, 2009). Selenide and elemental selenium occur in acidic, reducing, and organic-rich environments, such as swamps, wetlands, or bottom sediment. Reduced forms of selenium occur primarily as immobile solid phases, such as selenium-bearing pyrite, and are considered to have little toxicological significance (McNeal and Balistrieri, 1989; Naftz and Rice, 1989; Kulp and Pratt, 2004; Fernández-Martinez and Charlet, 2009). Selenide also forms complexes with organic matter, which can be biologically available and potentially toxic to plants and animals (Fernández-Martinez and Charlet, 2009). The oxidized species of selenium (selenite and selenate oxyanions) are mobile in the aquatic environment, are readily transported by surface-water and groundwater movement, and are toxic to plants and animals (Fernández-Martinez and Charlet, 2009). Selenite is generally mobile in the aquatic environment under mildly oxidizing conditions, and it is more bioavailable and more toxic than selenate (Lemly, 1993). Selenite can be immobilized by adsorption onto bentonite clays at $\mathrm{pH}$ values less than 7 and onto iron oxides at $\mathrm{pH}$ values between 5 and 8 (Balistrieri and Chao, 1987; McNeal and Balistrieri, 1989; Boult and others, 1998) and is more strongly adsorbed than selenate (Fernández-Martinez and Charlet, 2009). Selenate is highly mobile in the aquatic environment, especially under alkaline and oxidizing conditions (Naftz and Rice, 1989), forming soluble salts and weakly adsorbing to iron oxides, clay particles, and organic matter (McNeal and Balistrieri, 1989; Naftz and Rice, 1989; Kulp and Pratt, 2004). Selenate also substitutes for sulfate in the structure of gypsum (Fernández-González and others, 2006) and other evaporative salts such as thenardite $\left(\mathrm{Na}_{2} \mathrm{SO}_{4}\right)$ (Michele Tuttle, U.S. Geological Survey, written commun., 2012). 


\section{Study Area Description}

Toll Gate Creek is a perennial tributary of Sand Creek located near the eastern edge of the Denver metropolitan area in the municipality of Aurora, Colo. The study area encompasses the 18-km reach of West Toll Gate and Toll Gate Creek downstream from Quincy Reservoir to the confluence with Sand Creek. (fig. 2) as well as the surrounding area where groundwater monitoring wells were sampled.

\section{Physiography}

Toll Gate Creek originates in the west-central plains of the Denver Basin and flows north-northwest toward its confluence with Sand Creek, which in turn flows into the South Platte River. Neither Toll Gate Creek nor Sand Creek are used for drinking-water supply. West Toll Gate Creek drains the western part of the watershed and is the larger of the two tributaries that comprise Toll Gate Creek (fig. 2). East Toll Gate Creek drains the eastern part of the watershed. Quincy Reservoir is located along West Toll Gate Creek south of Quincy Avenue, although West Toll Gate Creek surface water is diverted around Quincy Reservoir. Hereinafter the sampled reaches of West Toll Gate Creek and Toll Gate Creek are referred to as "Toll Gate Creek."

Toll Gate Creek is located in the Great Plains physiographic province (Trimble, 1980) where topography is characterized by rolling hills and dissected plains. Land-surface altitude in the watershed ranges from about $1,859 \mathrm{~m}(6,100 \mathrm{ft})$ in the headwaters of West Toll Gate Creek to about 1,630 m $(5,250 \mathrm{ft})$ near the confluence with Sand Creek (fig. 2). Climate of the region is semiarid with mean annual precipitation averaging about 36 to 41 centimeters $(\mathrm{cm})(14$ to 16 inches [in]) in the basin for the period 1931-2003 (National Oceanic and Atmospheric Administration, 2003; Paschke, 2011). About 70 percent of the precipitation falls during the 6-month period from April through September as summer thundershowers, and the remaining 30 percent of precipitation mostly occurs as snowfall from November through March (Hansen and others, 1978). Native vegetation consists of grasslands with mixed-grass prairie and rangeland shrubs (Keith and Maberry, 1973) with phreatophytes such as cottonwoods, willows, and cattails occurring immediately adjacent to streams in valley bottom lands and flood plains (Keith and Maberry, 1973; Driscoll, 1975).

\section{Land Use}

Urbanization of the Toll Gate Creek watershed since the 1940s has changed the land use, vegetation, and hydrology of the area. Development of this part of Aurora began during World War II in response to residential and commercial growth surrounding nearby Buckley Air Force Base and former Lowry Air Force Base (fig. 3). In 1948, about
3.3 square kilometers $\left(\mathrm{km}^{2}\right)$ of the Toll Gate Creek watershed were urbanized, primarily in the northern part of the study area. From the 1960s to the 1990s, urbanization spread south through the Toll Gate Creek watershed such that by 2001, about $55 \mathrm{~km}^{2}$ of the $104 \mathrm{~km}^{2}$ watershed, or about 53 percent of the watershed, was urbanized (fig. 3). Rangeland prairie and shrubs were converted to lawns with trees and gardens in residential areas and to paved areas in transportation corridors and commercial developments.

\section{Surface-Water Hydrology}

Toll Gate Creek has undergone engineered channelization over much of its length as part of urbanization, and small tributaries were piped through culverts beneath roads and highways (Jill Piatt Kemper, City of Aurora, oral commun., 2007). These channelized tributaries and culverts also collect and carry shallow groundwater to Toll Gate Creek. At lowflow (base flow) conditions, streamflow in Toll Gate Creek is supported primarily by groundwater inflow. Downstream from Quincy Reservoir to Hampden Avenue, West Toll Gate Creek flows through a wetland area (figs. 4 and 5) passing under Mansfield Avenue. At Hampden Avenue, West Toll Gate Creek enters a concrete-lined channel (figs. 4 and 6), which extends from Hampden Avenue downstream to Buckley Road (figs. 4 and 7). The concrete-lined channel appears to prevent groundwater and thus selenium discharge to the stream on the basis of stream-selenium concentrations of about $5 \mu \mathrm{g} / \mathrm{L}$ measured in the reach by this study. The West Toll Gate Creek channel is unlined downstream from Buckley Road to the confluence with East Toll Gate Creek north of Alameda Avenue. Downstream from Mexico Avenue, a series of drop structures control flow in the creek (figs. 4 and 8) such that flow is relatively slow moving and, in some locations, stagnant behind each of these structures (figs. 4 and 9). Streamflow was difficult to quantify in these slow-moving reaches as described in the "Streamflow Conditions" section of this report. Downstream from the confluence of East and West Toll Gate Creeks, Toll Gate Creek flows about $5.4 \mathrm{~km}$ to its confluence with Sand Creek (figs. 4 and 10).

Toll Gate Creek is presently (2012) a perennial stream. Topographic maps from the 1960s show springs along West Toll Gate Creek near its confluence with East Toll Gate Creek, and historical accounts of the creek from the 1950s indicate perennial flow in some reaches at that time (Pyle, 1998). However, the creek was likely ephemeral prior to urbanization, with only occasional or local flow, similar to Sand Creek, Coal Creek, and other plains streams originating in eastern Colorado (Friedman and Lee, 2002). Increased water use in the area likely increased surface-water runoff, streamflow, and groundwater recharge and discharge in developed areas similar to the phenomena noted for the main stem of the South Platte River following agricultural development in the valley (Nadler and Schumm, 1981). 


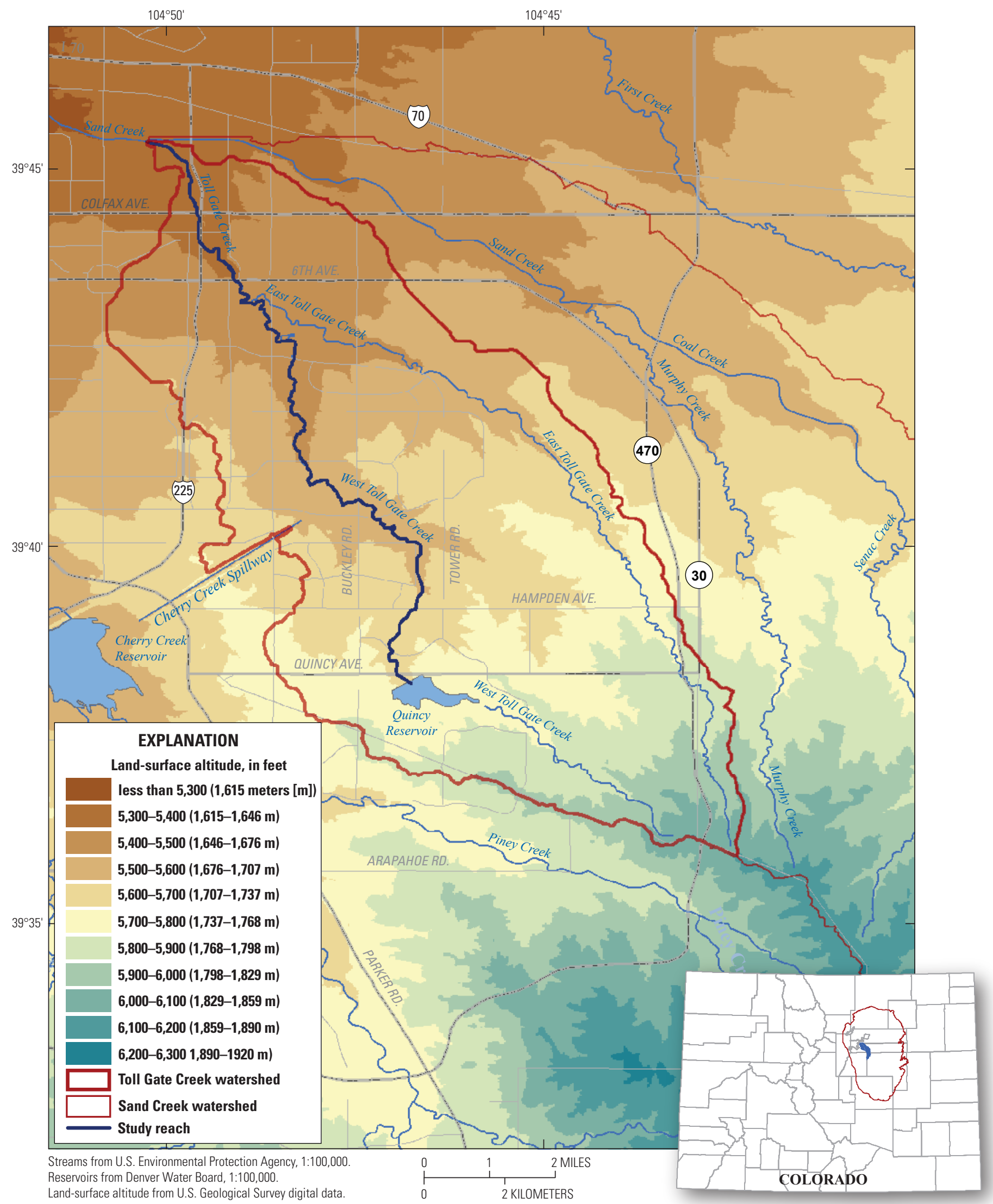

Figure 2. Map showing land-surface altitude and location of synoptic-sampling study reach for the Toll Gate Creek watershed, Aurora, Colorado. 


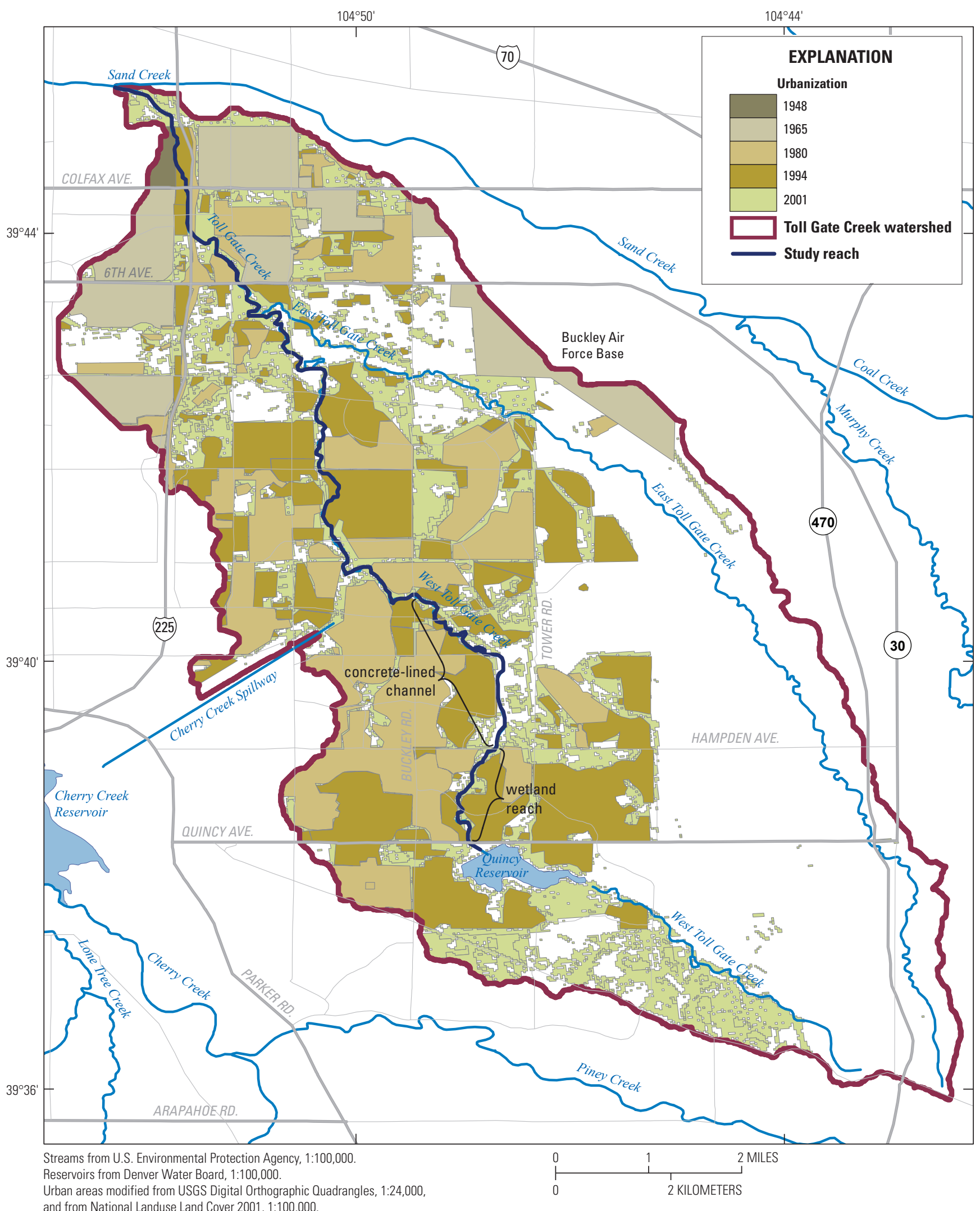

and from National Landuse Land Cover 2001, 1:100,000.

Figure 3. Map showing extent of urbanization since 1948 in the Toll Gate Creek watershed, Aurora, Colorado. 


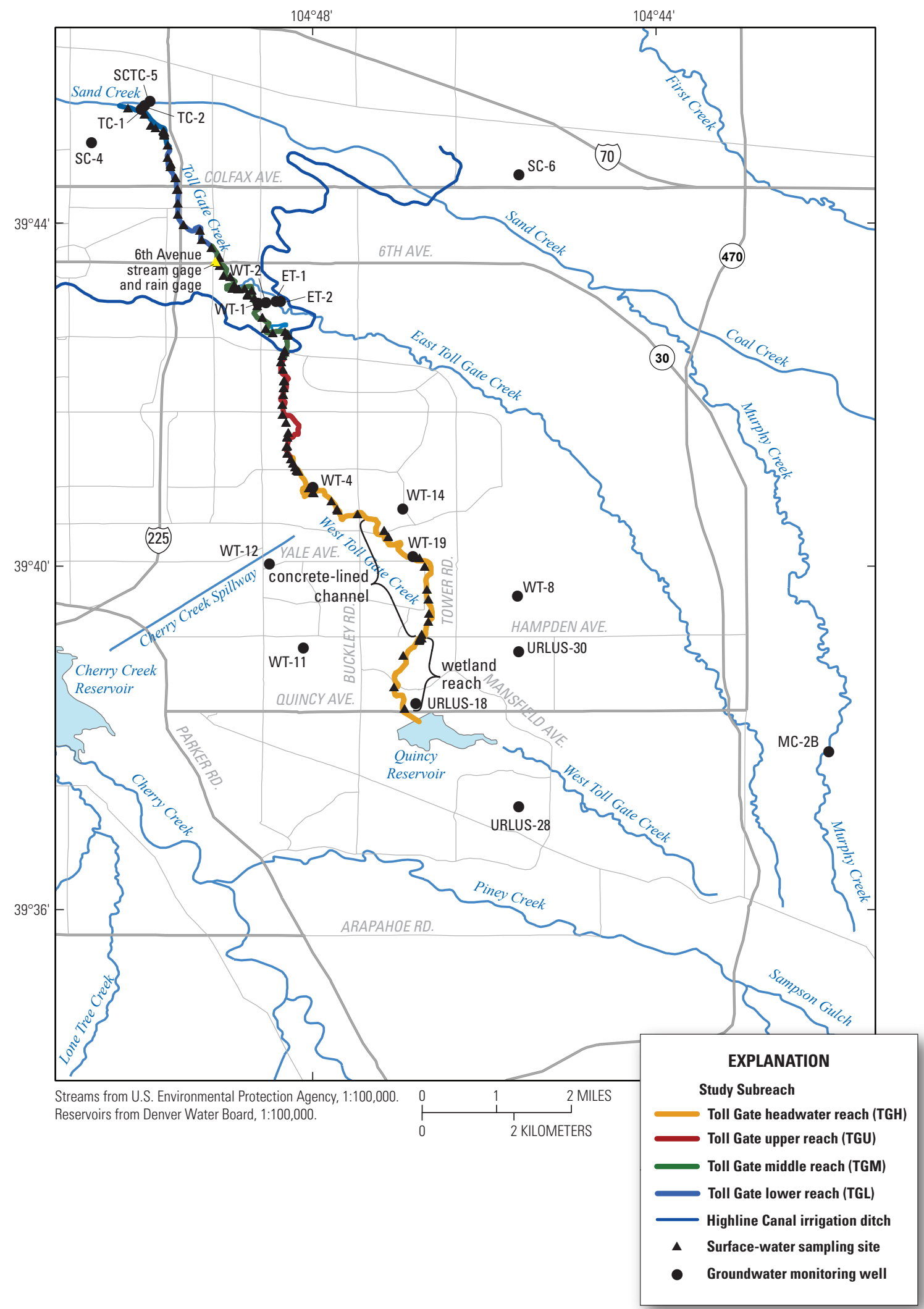

Figure 4. Map showing location of synoptic-sampling subreaches, surface-water sampling sites, groundwater monitoring wells, and the 6th Avenue stream gage (USGS gaging station 394329104490101), Toll Gate Creek, JulyAugust 2007. 


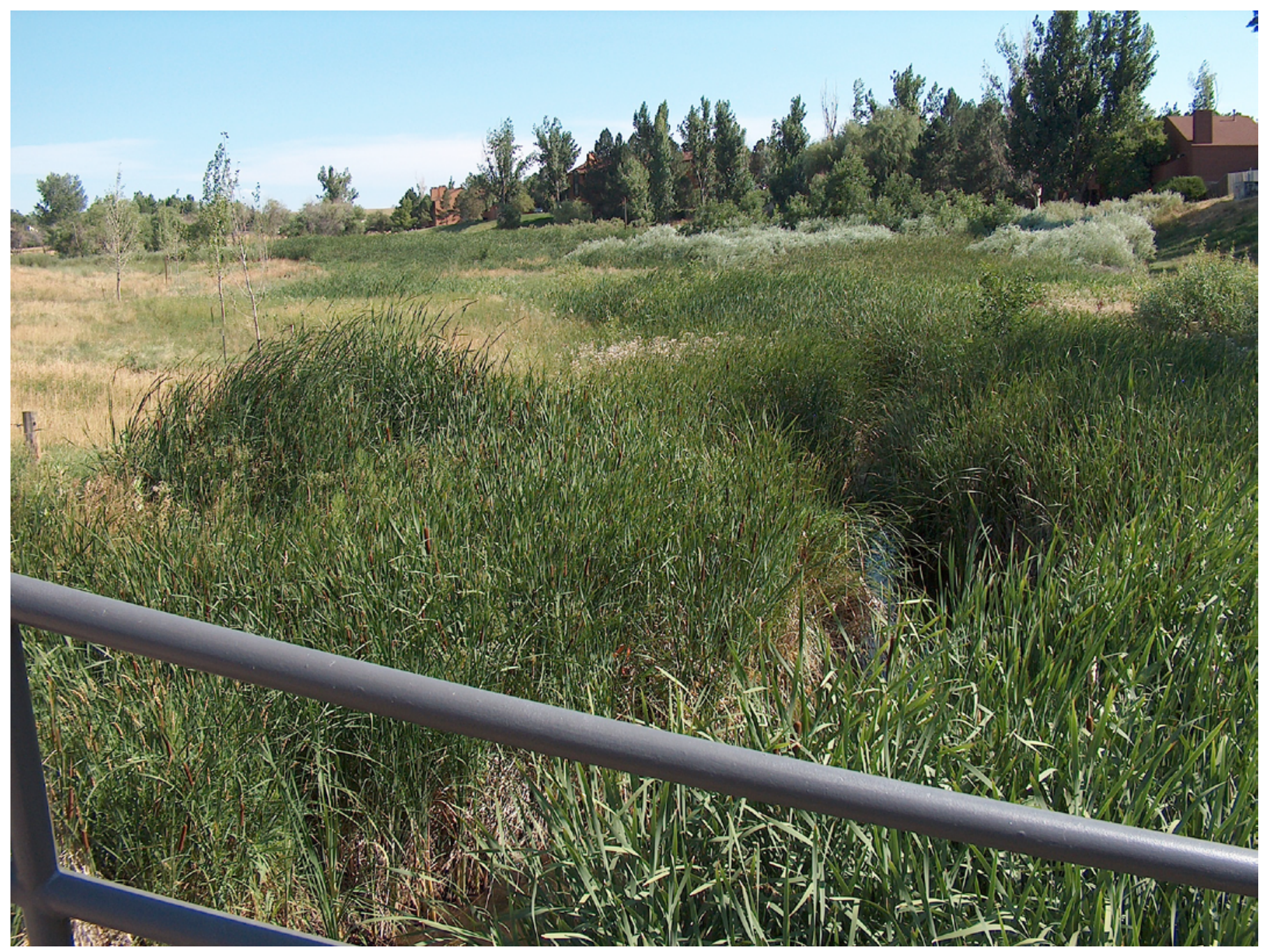

Figure 5. Photograph showing West Toll Gate Creek looking upstream from Mansfield Avenue toward Quincy Reservoir, Aurora, Colorado, July 2007 (Photograph by Suzanne Paschke). 


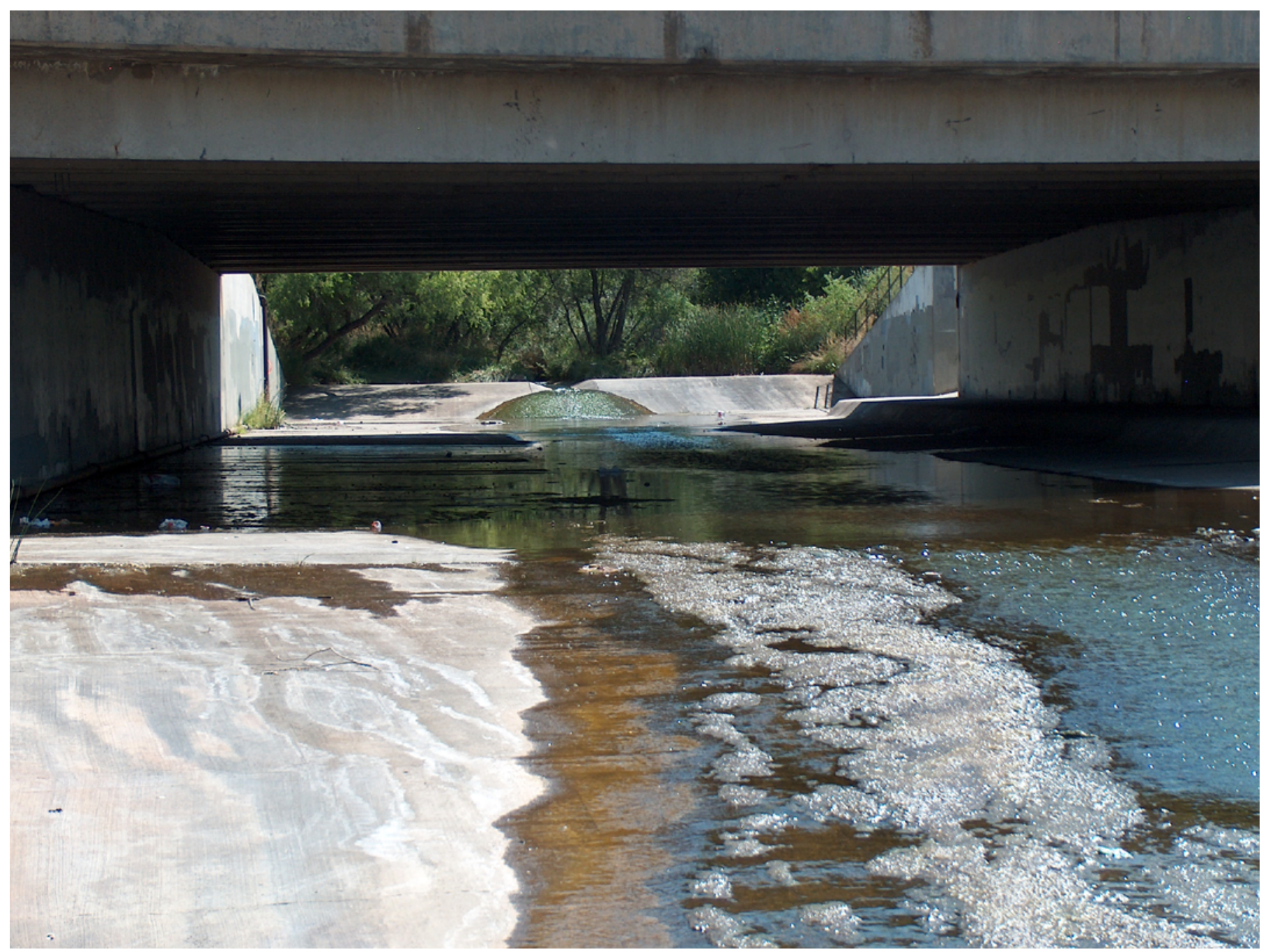

Figure 6. Photograph showing West Toll Gate Creek looking upstream beneath the Hampden Avenue bridge where stream enters the concrete-lined channel, Aurora, Colorado, July 2007 (Photograph by Suzanne Paschke). 


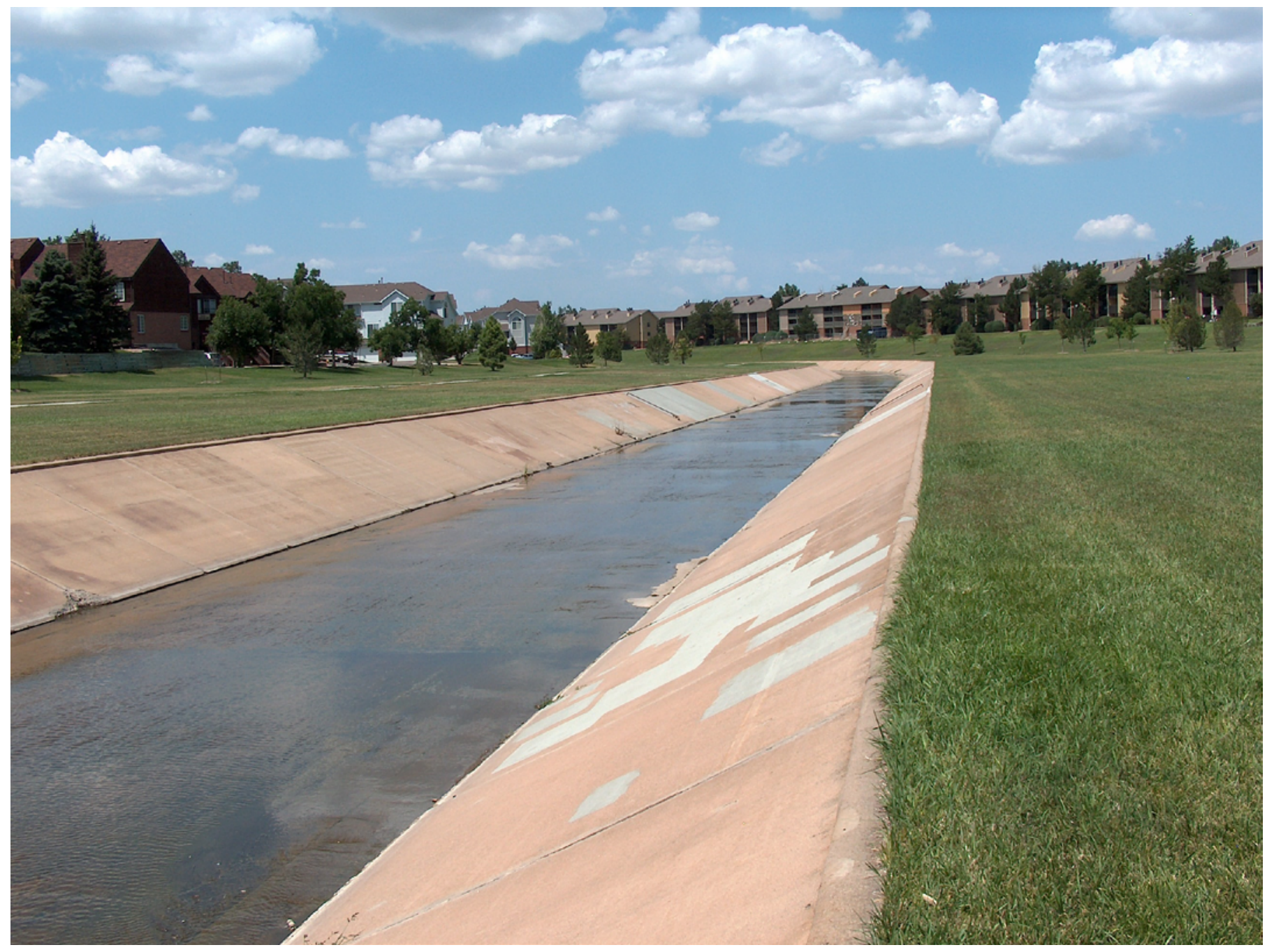

Figure 7. Photograph showing West Toll Gate Creek concrete-lined channel looking downstream toward Buckley Road, Aurora, Colorado, July 2007 (Photograph by Suzanne Paschke). 


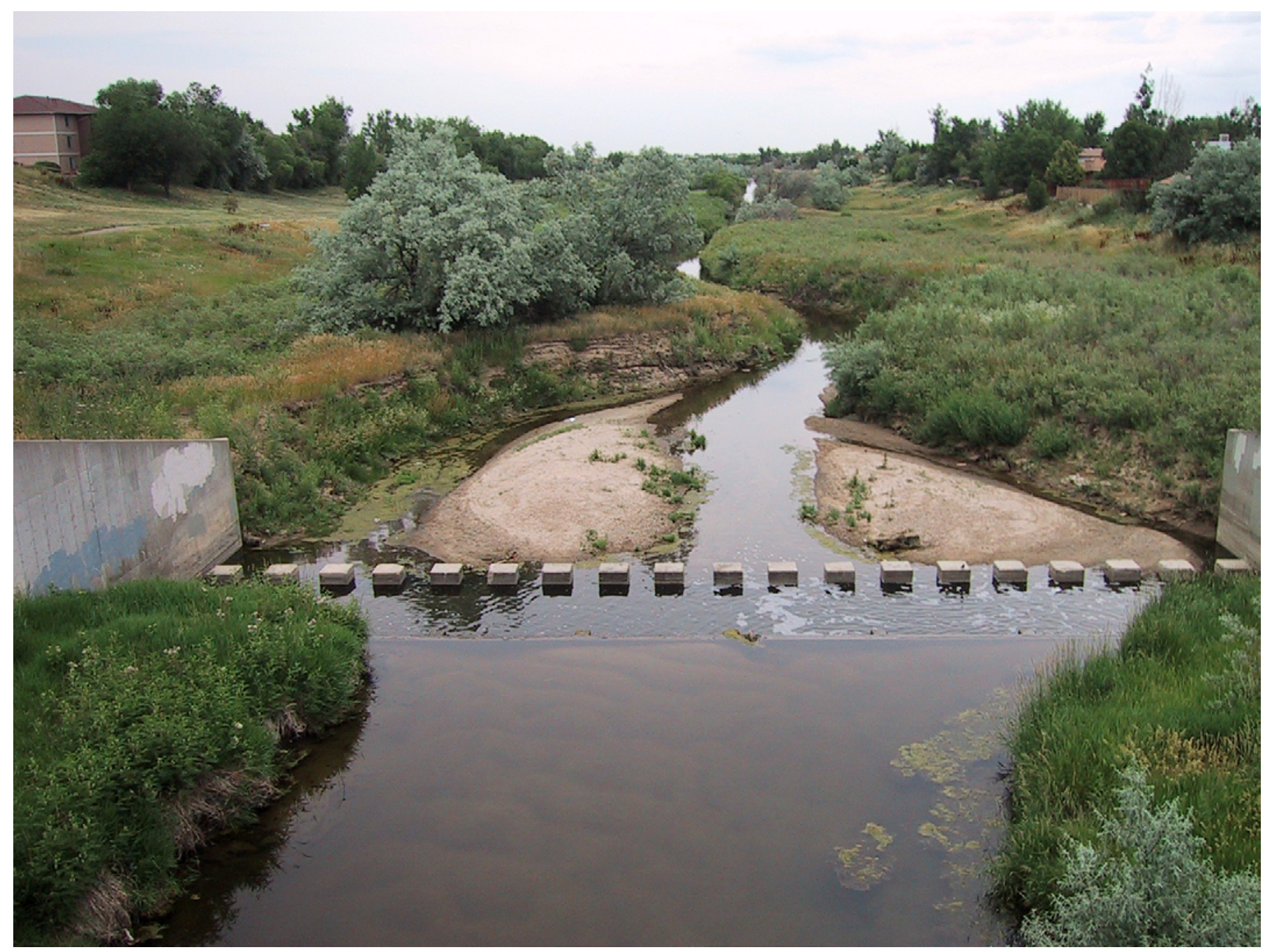

Figure 8. Photograph showing drop structure along West Toll Gate Creek downstream from Mexico Avenue, Aurora, Colorado, July 2007 (Photograph by Robert Runkel). 


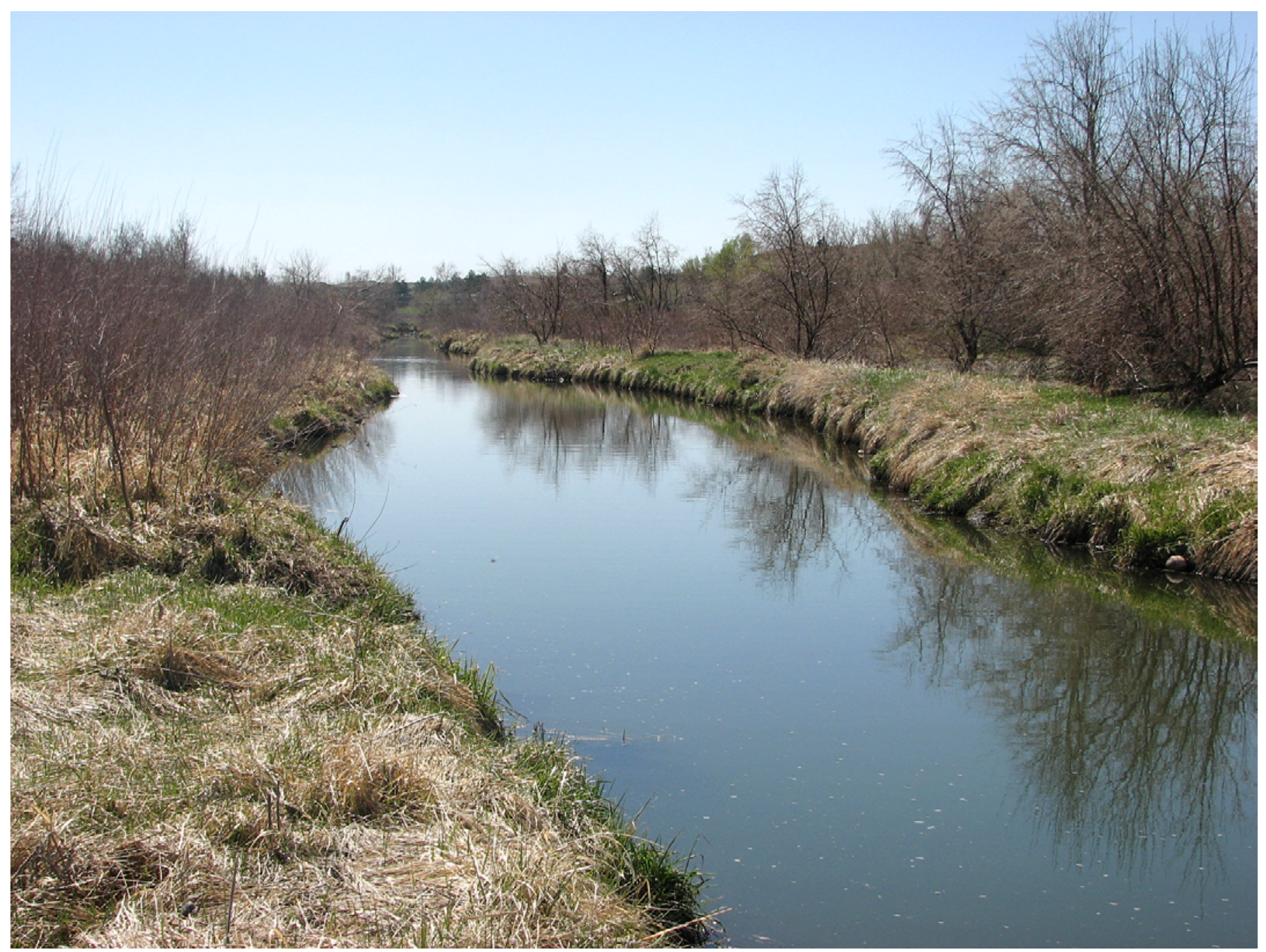

Figure 9. Photograph showing West Toll Gate Creek downstream from Mexico Avenue, Aurora, Colorado, April 2007 (Photograph by Suzanne Paschke). 


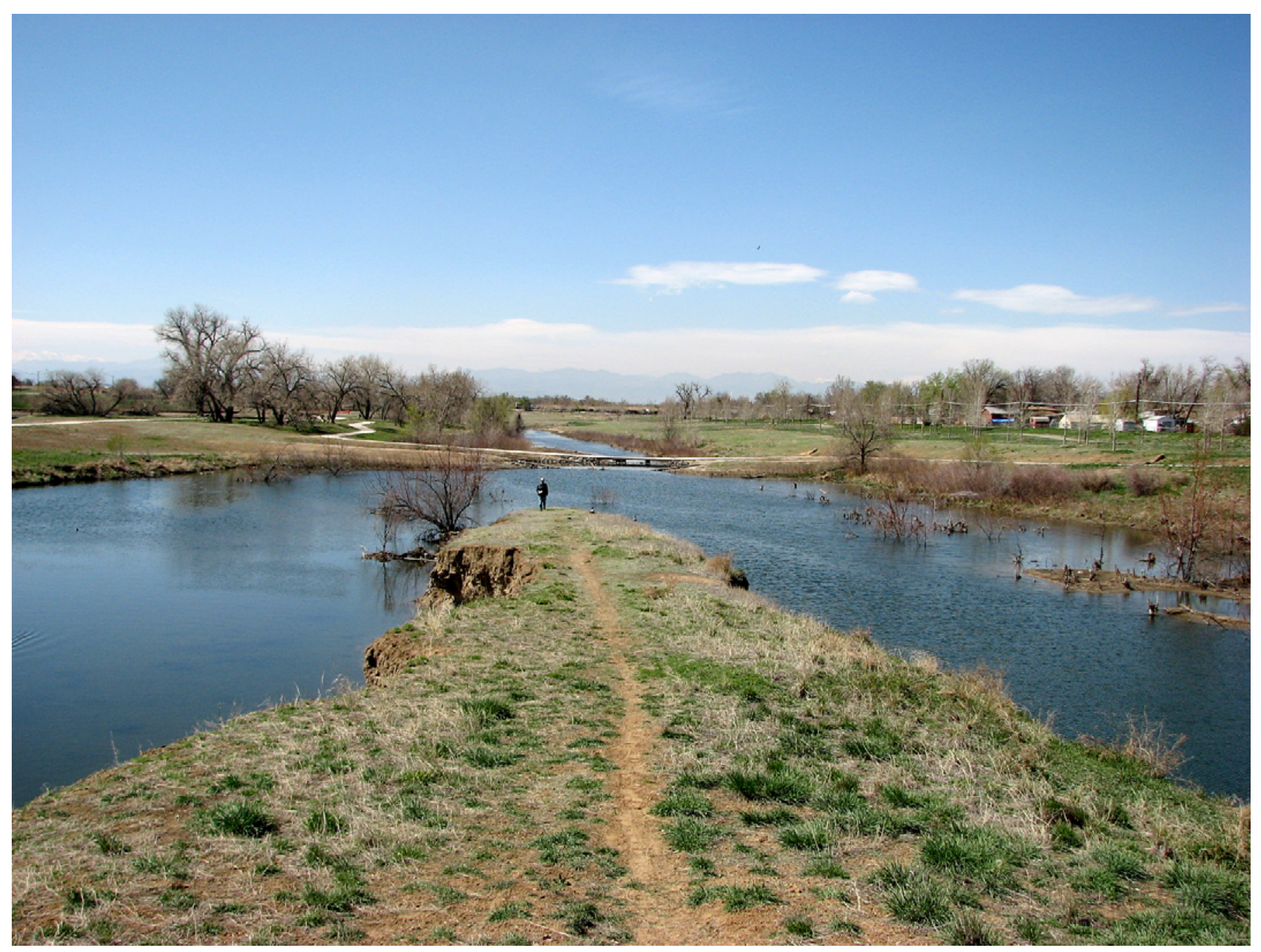

Figure 10. Photograph showing Toll Gate Creek (on left) and Sand Creek (on right) confluence. View looking downstream toward confluence, Aurora, Colorado, April 2007 (Photograph by Suzanne Paschke). 


\section{Geology and Groundwater Hydrology}

Groundwater hydrology of the Toll Gate Creek watershed is characterized by variably saturated water-table conditions in Quaternary unconsolidated surficial materials and the top of the underlying and weathered Cretaceous- to Tertiaryaged Denver Formation bedrock (Robson, 1996). Surficial materials include alluvial, colluvial, and eolian deposits. The alluvial deposits consist of gravel, sand, silt, and clay; colluvial deposits may consist of reworked alluvial deposits and underlying bedrock; and eolian deposits consist of fine- to medium-grained windblown sand (Robson, 1996). The water table may occur in surficial deposits or the weathered top of bedrock with depths to water generally less than $50 \mathrm{ft}$ below land surface and saturated thickness generally less than $20 \mathrm{ft}$ (Robson, 1996; Richard Vidmar, City of Aurora, written commun., 2007; this study). Organic-rich Denver Formation claystone underlies surficial materials in parts of the Toll Gate Creek watershed (Jennifer Beck, U.S. Geological Survey, written common., 2005; Richard Vidmar, City of Aurora, written commun., 2007), and the low-permeability claystone inhibits the downward movement of shallow groundwater such that a perched water-table exists in the surficial materials and underlying top of bedrock.

Denver Formation claystone is considered the geologic source of dissolved selenium and other inorganic constituents to surface water and groundwater in the Toll Gate Creek watershed. The Denver Formation that crops out and underlies surficial deposits in the Toll Gate Creek watershed consists of poorly consolidated nonmarine claystone and occasional beds of consolidated siltstone or sandstone, localized seams of lowrank coal (lignite), and lithified volcanic ash layers (tonsteins) (Kirkham and Ladwig, 1979; Robson and Romero, 1981; this study). Robson (1996) shows bedrock outcrops along the channel of Toll Gate Creek upstream from (south of) Quincy Reservoir and along the edges of valley-fill surficial materials downstream from Quincy Reservoir (fig. 11). Field reconnaissance for this study observed outcrops of claystone, and in some areas sandstone, in streambeds and cut banks, and drilling logs indicate that claystone underlies surficial materials at most drilled locations in the watershed (Jennifer Beck, U.S. Geological Survey, written commun., 2005; Richard Vidmar, City of Aurora, written commun., 2007). Tonsteins also were observed within the claystone bedrock (fig. 12).

Exposure of the Denver Formation bedrock to surface water, groundwater, and oxidizing atmospheric conditions has resulted in erosion and chemical weathering of the minerals and trace elements contained in the bedrock. Weathering in a semiarid climate creates alkaline and oxidizing conditions that oxidize the reduced mineral forms, such as seleniumbearing pyrite or selenium complexed with organic matter, and generate soluble selenium (Naftz and Rice, 1989). Secondary weathering products (iron oxides and salts) are evident in the Toll Gate Creek watershed and are similar to those observed in western Colorado for the Mancos Shale (Michele Tuttle, U.S. Geological Survey, written commun.,
2012). Weathered bedrock from groundwater monitoring well URLUS-30 in the Toll Gate Creek watershed is described as "yellow-brown to olive-gray claystone with iron staining and gypsum" (Jennifer Beck, U.S. Geological Survey, written commun., 2003). The presence of iron oxides and secondary salts indicates oxidized chemical conditions, whereas the unweathered claystone is generally grey to black in color, indicating abundant organic matter and reduced chemical conditions. The oxidation and weathering of reduced selenium-bearing minerals or organic material in the claystone bedrock is a likely mechanism for selenium dissolution and mobilization in the Toll Gate Creek watershed. Oxidized secondary selenium-bearing salts accumulated in the weathered zone also can dissolve in surface water or groundwater under present-day hydrologic conditions and also are possible sources of selenium to the aquatic environment of Toll Gate Creek (Michele Tuttle, U.S. Geological Survey, written commun., 2012).

Recharge to the water table is from infiltration of incident precipitation, surface-water infiltration, and deep percolation of lawn-irrigation water. Prior to urbanization, agricultural activities in the area likely contributed recharge to the water table by deep percolation of agricultural-irrigation water conveyed to fields by irrigation ditches. Irrigation water to the area historically was diverted from the South Platte River upstream from Aurora and carried through the Highline Canal (Pyle, 1998). The Highline Canal crosses the Toll Gate Creek watershed, and leakage from the Highline Canal has likely been a source of recharge to the local water table, although the effects of ditch leakage on groundwater flow were not examined by this study.

Groundwater-flow direction in the surficial materials and weathered bedrock is generally from south to north, down valley and toward Toll Gate Creek (fig. 11). Where claystones are present at the land surface or beneath surficial materials, they generally form a confining unit, which inhibits the downward movement of shallow groundwater, such that groundwater flow generally follows the top of bedrock toward local drainages. The uppermost layers of claystone are commonly saturated with shallow groundwater and weathered to a blocky appearance indicating the weathered zone is locally in hydraulic connection with the overlying surficial materials.

Groundwater discharges to Toll Gate Creek and its tributaries from discrete seeps, springs, and engineered culverts, which were sampled for this study, and by diffuse flow and evaporation. Seeps and springs observed along the Toll Gate Creek channel margins during field reconnaissance for this study occur at the weathered contact between the surficial materials and the underlying less-permeable claystone bedrock. Toll Gate Creek has eroded through (incised) the surficial materials and weathered bedrock along parts of the study reach so that the stream also flows directly on bedrock. Evaporative salt deposits observed on the surface of bedrock outcrops and along streambanks are evidence for evaporation from groundwater discharge and the stream hyporheic zone (Herring and Walton-Day, 2007) (fig. 12). 


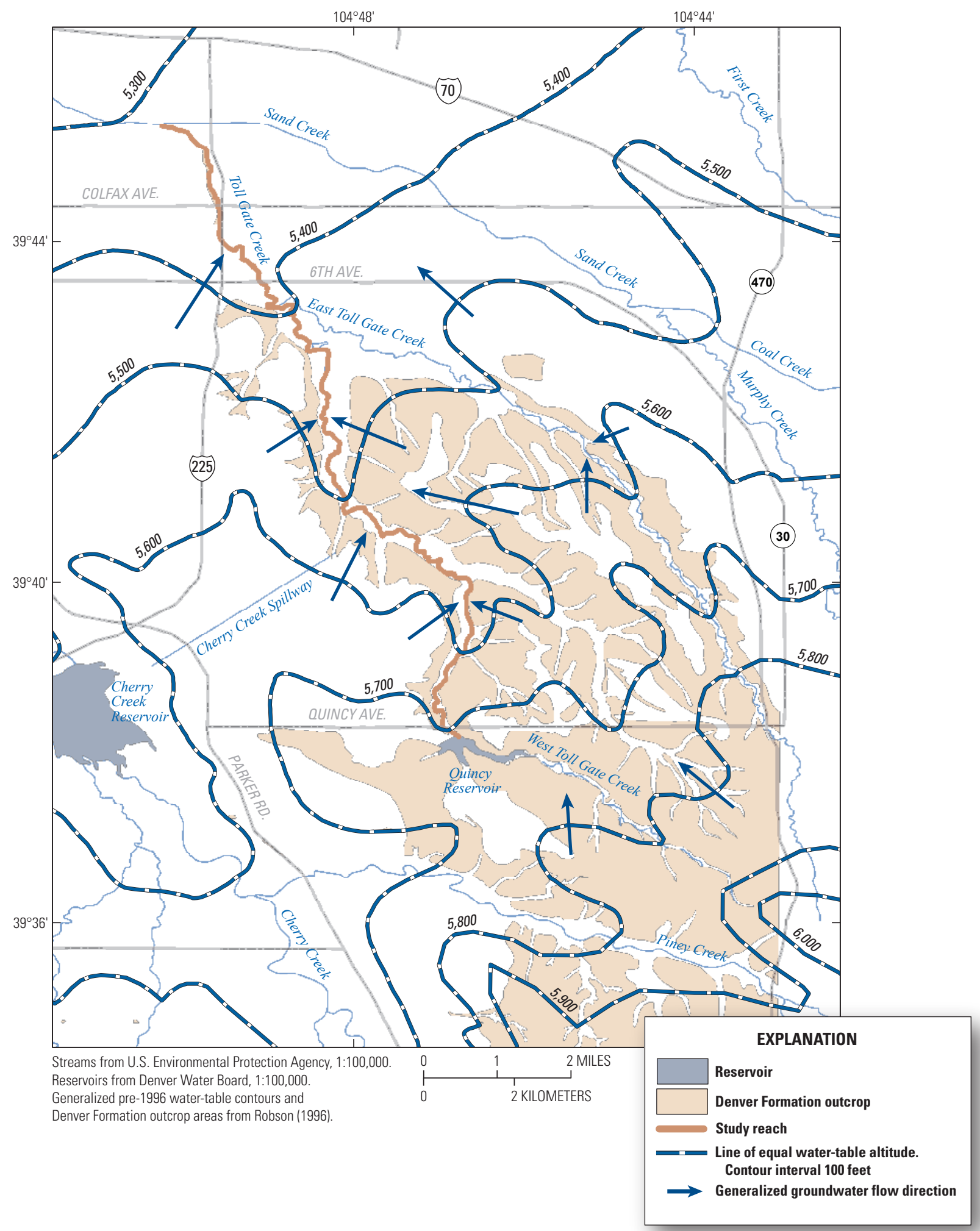

Figure 11. Map showing Denver Formation outcrop and water-table altitude contours, Toll Gate Creek, Aurora, Colorado (after Robson, 1996). 


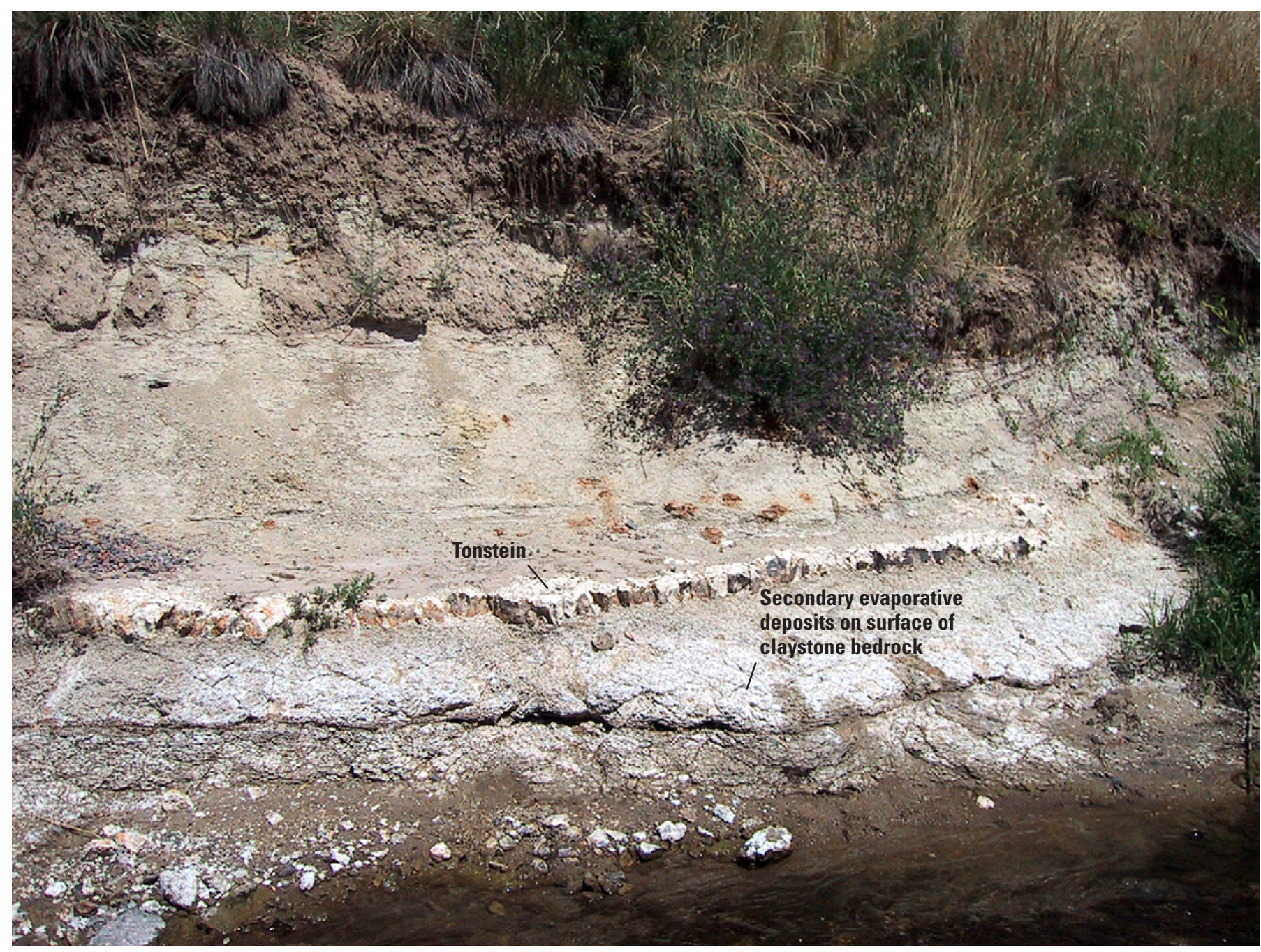

Figure 12. Photograph showing tonstein within and secondary evaporative deposits on surface of Denver Formation claystone bedrock outcrop along Toll Gate Creek streambank, Aurora, Colorado, July 2007 (Photograph by Suzanne Paschke).

\section{Methods}

This study characterized streamflow and water-quality conditions including geologic sources and processes affecting selenium loading in the Toll Gate Creek watershed for summer low-flow conditions in 2007. This report section describes the field and analytical methods used for synoptic sampling, tracer injection, mass-loading calculations, multivariate analysis, groundwater sampling, and solids sampling. Quality-assurance and quality-control results also are presented.

\section{Synoptic-Sampling and Tracer-Injection Background}

Synoptic-sampling and tracer-injection methods developed by the USGS Toxic Substances Hydrology Program (Kimball and others 2002, 2007) were used to develop spatial profiles of concentration, streamflow, and load in Toll Gate Creek. These methods have been applied primarily to assess metal loading from abandoned mine lands (Bencala and McKnight, 1987; Paschke and others, 2005; Runkel and others, 2007, 2009; Walton-Day and others, 2005), but they also are applicable to other constituents in gaining streams (for example, Kimball and others, 2008). 
Quantification of constituent load in a stream requires accurate streamflow measurements and representative concentrations of chemical constituents. Estimates of streamflow at each stream sampling location can be developed using the tracer-dilution method (Kilpatrick and Cobb, 1985) or currentmeter measurements (Rantz and others, 1982). Synoptic sampling (Bencala and McKnight, 1987; Kimball and others, 2002) provides a detailed spatial profile of constituent concentration in the stream and its tributaries. Spatial profiles of in-stream load are in turn used to identify constituent sources (increases in load with distance) and sinks (decreases in load with distance).

Synoptic water-quality studies typically are conducted during base-flow (low-flow) conditions. Application of the synoptic-sampling approach to low-flow conditions is appropriate for two reasons. First, the mass-loading profiles developed for low-flow conditions generally provide a strong representation of groundwater discharge that is not diluted by excess surface-water runoff. Second, during the low-flow periods, dilution of chemical constituents is minimal, and toxicity standards based on metal concentrations are more likely exceeded (Besser and others, 2001). Low-flow conditions also make it logistically possible to measure streamflow and collect samples at many synoptic-sampling sites in a single day.

Tracer injection is a method of estimating streamflow in gaining streams (Kilpatrick and Cobb, 1985). A tracer injection consists of continuously injecting an inert chemical tracer into the stream at a constant rate and concentration and measuring the downstream dilution of the tracer at various locations. Given sufficient time during a tracer injection, all portions of the stream including side pools and the hyporheic zone will become saturated with tracer, and in-stream tracer concentrations will reach a plateau (Kimball and others, 2002). Downstream decreases in tracer plateau concentration indicate tracer dilution by surface-water and groundwater inflow to the stream, and streamflow is calculated from the downstream dilution. The downstream arrival, concentration plateau, and departure (upon cessation of the injection) of the tracer also are monitored at selected transport sites to compute stream velocities and other hydrologic properties.

Synoptic sampling is a one-time detailed sampling of stream sites and all visible tributary inflows to the stream that provides a description of the stream and tributary inflow chemistry. Synoptic sampling generally is performed during the plateau period of the tracer injection. Streamflow computed from tracer concentrations in samples collected during synoptic sampling accounts for both the surface and the hyporheic flow because the tracer flows with the water through bed sediment. The tracer-injection method also allows streamflow estimates at numerous locations in a short time frame. Zellweger and others (1988) provide additional details of tracer-injection methods. The section of this report, "Synoptic Sampling and Tracer Injections" describes the specific synoptic-sampling and tracer-injection methods used for this study.
Loading profiles developed for the stream use massbalance calculations, which combine streamflow with constituent concentrations in synoptic samples. Loadingcalculation results for a synoptic study can identify where changes in stream load occur and can lend insight to sources of loading and potential geochemical controls on stream chemistry. However, study results do not identify specific pathways to the stream from particular sites, except for visible inflows. The section of this report, "Surface-Water Mass-Loading Calculations" describes the specific loading calculations used for this study.

\section{Toll Gate Creek Stream Reaches and Sampling Sequence of Events}

The 18-km study reach was divided into four subreaches for synoptic sampling (fig. 4). To quantify day-to-day variability in streamflow and constituent concentration, the subreaches overlapped; with one or more stream sites at the end of each subreach being shared with the downstream subreach (for example, the one or two most downstream sites in a given subreach comprise the two most upstream sites of the next subreach). Synoptic sampling of each subreach occurred on different days, so the overlapping stream sites were sampled on two different days (table 1). Study subreaches are labeled as Toll Gate headwaters subreach (TGH, Quincy Reservoir to Mexico Avenue), Toll Gate upper injection subreach (TGU, Mexico Avenue to Alameda Avenue), Toll Gate middle injection subreach (TGM, Alameda Avenue to 6th Avenue), and Toll Gate lower injection subreach (TGL, 6th Avenue to Sand Creek) (fig. 4).

Detailed field reconnaissance of the study reach downstream from the end of the concrete-lined channel at Buckley Road (lower part of TGH and all of TGU, TGM, and TGL) was accomplished June 27-29, 2007, and reconnaissance downstream from Quincy Reservoir to upstream from Buckley Road (upper part of TGH) was accomplished on July 27, 2007 (table 1). During field reconnaissance, stream- and inflow-sampling locations were identified, noted, flagged, and recorded with a Global Positioning System device so they could be revisited during the synoptic sampling. Streambed and inflow characteristics also were observed and recorded. Field reconnaissance resulted in a spatially detailed sampling plan and understanding of the stream and inflows (tributaries, culverts, seeps, and springs). Hydrologic properties of the subreaches (time of travel and time to plateau) were determined using instream releases of Rhodamine WT dye in the TGU, TGM, and TGL subreaches July 9-14, 2007.

Synoptic sampling was accomplished on the TGU, TGM, and TGL subreaches July 26-August 2, 2007. Each of these sampling events employed tracer injections that allowed for the determination of streamflow using the tracer-dilution method. Tracer injections continued for 2-3 days, allowing time for the injected tracer to fully saturate the stream and hyporheic zone, such that a steady-state tracer plateau concentration was achieved (Kimball and others, 2002, 2007). 
Upon reaching the plateau, synoptic samples were collected (July 26, July 29, and August 2; table 1) at the predetermined stream and inflow locations (table 2). A tracer injection was not attempted on the TGH subreach because of the presence of wetlands and the concrete-lined channel. Streamflow was measured in the TGH subreach downstream from Buckley Road using a current meter during synoptic sampling on August 1, 2007. No streamflow measurements were obtained upstream from Buckley Road because of the presence of wetlands and the concrete-lined channel that prevented execution of both tracer injection and current-meter streamflow measurements. Groundwater sampling at selected locations (fig. 4) occurred July 12-August 6, 2007, such that groundwater samples are considered synoptic with the surface-water samples (table 1).

\section{Synoptic Sampling and Tracer Injections}

Water-quality samples were collected from all surfacewater sites within the TGH, TGU, TGM, and TGL subreaches on the specific days listed in table 1 starting with the most downstream subreach (TGL) and generally proceeding upstream. In total, samples were collected from 63 stream and 32 inflow locations (table 2). Sample collection within each subreach proceeded in the downstream-to-upstream direction to prevent suspended streambed sediments, dislodged by sampling teams, from contaminating downstream samples. Water-quality samples at all stream locations were collected using a DH-81 sampling device and equal-width-increment sampling methods such that constituent concentrations were width and depth integrated and represent a velocity-weighted cross-sectional average (U.S. Geological Survey, variously dated). Stream samples were collected as rapidly as possible to minimize site-to-site variation in water quality caused by diel constituent fluctuations and changes in streamflow (Nimick and others, 2003). Elapsed time between adjacent stream samples was about 20 minutes. Manual grab samples were collected at all inflow sites. Water temperature was measured at each site during sample collection.

A spatially detailed profile of streamflow was developed using current-meter measurements and tracer-dilution estimates as described in Appendix 1. Current-meter measurements were made at stream sampling locations (Rantz and others, 1982) using a handheld Acoustic Doppler Velocity meter (ADV, Flow Tracker $\left.{ }^{\circledR}\right)$. Tracer-dilution estimates of streamflow were available for most stream sampling locations within the TGU, TGM, and TGL subreaches, where conservative tracer injections were initiated in the days prior to synoptic sampling (table 1). All tracer injections implemented a continuous, constant-rate injection (Kimball and others, 2002, 2007) of a concentrated sodium bromide solution.

During each synoptic-sampling event, two to four sites were instrumented with automatic sampling devices, pressure transducers, and continuous specific-conductance meters to help monitor tracer arrival and plateau along the study reach. These data were also useful in evaluating the timing of the effects of rain along the study reach. Only a limited amount of these data are included in this report.

\section{Surface-Water Sample Processing and Analytical Methods}

Surface-water samples were transferred from the DH-81 sampling device to one-gallon polyethylene bottles and transported to a field laboratory where aliquots were prepared for various constituent analyses (table 3). Surface-water samples were analyzed for physical properties, major ions, trace elements, nutrients, and hydrogen and oxygen stable-isotope ratios (table 3). Onsite processing included measurement of $\mathrm{pH}$ and specific conductance (SC) in unfiltered samples, sample filtration, and sample preservation for cation and nutrient analysis. Filtration was completed using 0.45-micrometer capsule filters, and constituent concentrations obtained from analysis of the 0.45 -micrometer filtrate are referred to as "dissolved" concentrations in this report. Filtered aliquots for dissolved major-cation and trace-metal analysis (aluminum, calcium, iron, magnesium, manganese, selenium, sodium, uranium, and zinc) were preserved to a $\mathrm{pH}$ less than 2 with 1 milliliter of ultrapure nitric acid. Aliquots for dissolved nutrient analysis (orthophosphate and ammonia, nitrite, and nitrite plus nitrate as nitrogen) were maintained at $4{ }^{\circ} \mathrm{C}$ until they were submitted to the USGS National Water Quality Laboratory (NWQL) in Lakewood, Colo. Total nitrogen and phosphorous were determined from unfiltered aliquots that were preserved in the field with 1 milliliter of $4.5 \mathrm{~N}$ sulfuric acid and were maintained at $4{ }^{\circ} \mathrm{C}$ until they were submitted to the NWQL.

Laboratory analyses were performed at the NWQL in Lakewood, Colo., unless specified otherwise. Laboratory analyses of surface-water samples included general sample properties (alkalinity and total dissolved solids), dissolved silica, dissolved anions, and unfiltered and dissolved major cations and trace elements (table 3). In addition, 45 of 108 surface-water samples, including 15 inflows, were analyzed for nutrients and stable-isotope ratios of hydrogen and oxygen. Alkalinity and total dissolved solids were analyzed on filtered samples using methodology described in Fishman and Friedman (1989). Silica concentrations greater than or equal to 0.2 milligrams per liter $(\mathrm{mg} / \mathrm{L})$ were determined colorimetrically after a reaction with a molybdate reagent in acid (Fishman and Friedman, 1989). Silica concentrations less than $0.2 \mathrm{mg} / \mathrm{L}$ were determined using inductively coupled plasmaatomic emission spectrometry (ICP-AES) (Fishman, 1993).

Anion analysis included dissolved bromide, chloride, and sulfate determined using ion-exchange chromatography. Major-cation and trace-element analysis included unfiltered and dissolved concentrations of aluminum, calcium, iron, magnesium, manganese, selenium, sodium, uranium, and zinc. Dissolved concentrations of selenium and zinc were determined using collision/reaction cell inductively coupled plasma-mass spectrometry (cICP-MS) (Garbarino and others, 2006). Dissolved concentrations of the remaining cations were measured from filtered and acidified samples using ICP-AES (Fishman, 1993). Concentrations of major cations and trace elements in unfiltered samples were measured after in-bottle acid digestions following the methods of Garbarino and Struzeski (1998). 
Table 1. Toll Gate Creek synoptic surface-water sampling, tracer injection, and groundwater sampling sequence of events, 2007.

[NA, not applicable; TGH, Toll Gate Creek headwater subreach; TGU, Toll Gate Creek upper subreach; TGM, Toll Gate Creek middle subreach; TGL Toll Gate Creek lower subreach]

\begin{tabular}{llll}
\hline \multicolumn{1}{c}{ Date } & \multicolumn{1}{c}{ Subreach } & \multicolumn{1}{c}{ Activity } & Purpose \\
\hline June 27-29, 2007 & lower TGH, TGU, TGM, TGL & Stream reconnaissance & Identify and map stream and inflow sampling locations \\
July 12-August 6, 2007 & NA & Groundwater sampling & Determine groundwater quality upgradient of sampled surface-water reaches \\
July 9-14, 2007 & TGU, TGM, TGL & Instream dye releases & Determine travel-time for planning tracer injections \\
July 24-26, 2007 & TGL & Tracer injection & Characterize hydrology of subreach and estimate stream flow \\
July 26, 2007 & TGL & Synoptic sampling of stream sites and inflows & Determine water quality of stream and inflows \\
July 27-29,2007 & TGM & Tracer injection & Characterize hydrology of subreach and estimate stream flow \\
July 27, 2007 & Upper TGH & Stream reconnaissance & Identify and map stream and inflow sampling locations \\
July 29, 2007 & TGM & Synoptic sampling of stream sites and inflows & Determine water quality of stream and inflows \\
July 30-August 2,2007 & TGU & Tracer injection & Characterize hydrology of subreach and estimate stream flow \\
August 1,2007 & TGH & Synoptic sampling of stream sites and inflows & Determine water quality of stream and inflows \\
August 2,2007 & TGU & Synoptic sampling of stream sites and inflows & Determine water quality of stream and inflows \\
\hline
\end{tabular}

Table 2. Site information for stream and inflow synoptic-sampling sites, Toll Gate Creek, July-August 2007.

[Site ID, U.S. Geological Survey site identification number; Sample ID, synoptic-sample identification number; TG, Toll Gate; WP, waypoint number assigned by Global Positioning System unit; LBI, leftbank inflow; RBI, right-bank inflow; TGH, Toll Gate Creek headwaters subreach; TGU, Toll Gate Creek upper subreach; TGM, Toll Gate Creek middle subreach; TGL, Toll Gate Creek lower subreach; m, meters; E., East; in., inch; ₹, approximately; ft., foot; m, meter]

\begin{tabular}{|c|c|c|c|c|c|c|c|c|c|}
\hline Site ID & Sample ID & Site Name & Source & $\begin{array}{c}\text { Distance } \\
\text { from Quincy } \\
\text { Reservoir } \\
\text { (meters) }\end{array}$ & Site Description & $\begin{array}{l}\text { Latitude } \\
\text { (decimal } \\
\text { degrees) }\end{array}$ & $\begin{array}{l}\text { Longitude } \\
\text { (decimal } \\
\text { degrees) }\end{array}$ & $\begin{array}{c}\text { Altitude } \\
\text { (feet) }\end{array}$ & Subreach \\
\hline 393821104465601 & TG-WP451 & TG-WP451 stream site at WP451 & Stream & 0 & $\begin{array}{l}\text { West Toll Gate Creek downstream from } \\
\text { Quincy Reservoir (just downstream from } \\
\text { E Quincy Avenue) }\end{array}$ & 39.63911 & -104.782 & 5,597 & TGH \\
\hline 393836104470301 & TG-WP453 & TG-WP453 stream site at WP453 & Stream & 628 & $\begin{array}{l}\text { West Toll Gate Creek upstream from East } \\
\text { Mansfield Avenue }\end{array}$ & 39.64326 & -104.784 & 5,677 & TGH \\
\hline 393858104465701 & TG-WP457 & TG-WP457 left-bank inflow at WP457 & LBI & 1,337 & & 39.64933 & -104.782 & 5,644 & TGH \\
\hline 393908104464501 & TG-WP459 & TG-WP459 stream site at WP459 & Stream & 1,748 & West Toll Gate Creek & 39.65231 & -104.779 & 5,636 & TGH \\
\hline 393909104464502 & TG-WP460 & TG-WP460 right-bank inflow at WP460 & RBI & 1,772 & $\begin{array}{l}\text { Small unnamed creek collecting groundwater } \\
\text { discharge and storm runoff }\end{array}$ & 39.65251 & -104.779 & 5,629 & TGH \\
\hline 393910104464501 & TG-WP461 & TG-WP461 right-bank inflow at WP461 & RBI & 1,794 & & 39.65278 & -104.779 & 5,633 & TGH \\
\hline 393910104464502 & TG-WP462 & TG-WP462 stream site at WP462 & Stream & 1,809 & $\begin{array}{l}\text { West Toll Gate Creek upstream from Hamp- } \\
\text { den Avenue }\end{array}$ & 39.65274 & -104.779 & 5,629 & TGH \\
\hline
\end{tabular}


Table 2. Site information for stream and inflow synoptic-sampling sites, Toll Gate Creek, July-August 2007.—Continued

[Site ID, U.S. Geological Survey site identification number; Sample ID, synoptic-sample identification number; TG, Toll Gate; WP, waypoint number assigned by Global Positioning System unit; LBI, leftbank inflow; RBI, right-bank inflow; TGH, Toll Gate Creek headwaters subreach; TGU, Toll Gate Creek upper subreach; TGM, Toll Gate Creek middle subreach; TGL, Toll Gate Creek lower subreach; m, meters; E., East; in., inch; $\approx$, approximately; ft., foot; m, meter]

\begin{tabular}{|c|c|c|c|c|c|c|c|c|c|}
\hline Site ID & Sample ID & Site Name & Source & $\begin{array}{l}\text { Distance } \\
\text { from Quincy } \\
\text { Reservoir } \\
\text { (meters) }\end{array}$ & Site Description & $\begin{array}{l}\text { Latitude } \\
\text { (decimal } \\
\text { degrees) }\end{array}$ & $\begin{array}{l}\text { Longitude } \\
\text { (decimal } \\
\text { degrees) }\end{array}$ & $\begin{array}{l}\text { Altitude } \\
\text { (feet) }\end{array}$ & Subreach \\
\hline 393913104464401 & TG-WP463 & TG-WP463 stream site at WP463 & Stream & 1,893 & $\begin{array}{l}\text { West Toll Gate Creek in concrete channel } \\
\text { downstream from Hampden Avenue }\end{array}$ & 39.65354 & -104.779 & 5,649 & TGH \\
\hline 393921104463901 & TG-WP466 & TG-WP466 right-bank inflow at WP466 & RBI & 2,181 & $\begin{array}{l}\text { Culvert inflow, } \approx 50 \mathrm{~m} \text { downstream from } \\
\text { Hampden Avenue. Possible former } \\
\text { tributary. }\end{array}$ & 39.65595 & -104.778 & 5,608 & TGH \\
\hline 393927104463901 & TG-WP467 & TG-WP467 stream site at WP467 & Stream & 2,356 & West Toll Gate Creek in concrete channel & 39.65753 & -104.777 & 5,604 & TGH \\
\hline 393937104463901 & TG-WP468 & TG-WP468 right-bank inflow at WP468 & RBI & 2,668 & Seepage from concrete joint & 39.66031 & -104.778 & 5,592 & TGH \\
\hline 393944104464001 & TG-WP470 & TG-WP470 stream site at WP470 & Stream & 2,886 & West Toll Gate Creek in concrete channel & 39.66225 & -104.778 & 5,592 & TGH \\
\hline 394000104464201 & TG-WP472 & TG-WP472 stream site at WP472 & Stream & 3,413 & $\begin{array}{l}\text { West Toll Gate Creek at inlet to reservoir near } \\
\text { Vassar Elementary School }\end{array}$ & 39.66674 & -104.778 & 5,571 & TGH \\
\hline 394006104464501 & TG-WP453B & TG-WP453B stream site at WP453B & Stream & 3,646 & & 39.66836 & -104.779 & & TGH \\
\hline 394021104470701 & TG-WP452 & TG-WP452 stream site at WP452 & Stream & 4,539 & & 39.67242 & -104.785 & 5,576 & TGH \\
\hline 394025104471001 & TG-WP451RLR & $\begin{array}{l}\text { TG-WP451RLR right-bank inflow at } \\
\text { WP451RLR }\end{array}$ & RBI & 4,707 & $\begin{array}{l}\text { Culvert inflow under Iliff Avenue. Possible } \\
\text { former tributary piped to culvert. }\end{array}$ & 39.67361 & -104.786 & 5,565 & TGH \\
\hline 394037104472901 & TG-0 & TG-0 stream site at $0 \mathrm{~m}$ & Stream & 5,330 & $\begin{array}{l}\text { West Toll Gate Creek, end of concrete chan- } \\
\text { nel at Buckley Road }\end{array}$ & 39.67683 & -104.791 & 5,557 & TGH \\
\hline 394039104474201 & TG-371 & TG-371 stream site at $371 \mathrm{~m}$ & Stream & 5,701 & $\begin{array}{l}\text { West Toll Gate Creek, } \approx 370 \mathrm{~m} \text { downstream } \\
\text { from Buckley Road }\end{array}$ & 39.67737 & -104.795 & 5,556 & TGH \\
\hline 394039104474301 & TG-383 & TG-383 left-bank inflow at $383 \mathrm{~m}$ & LBI & 5,713 & & 39.67742 & -104.795 & 5,539 & TGH \\
\hline 394046104474701 & TG-626 & TG-626 stream site at $626 \mathrm{~m}$ & Stream & 5,956 & $\begin{array}{l}\text { West Toll Gate Creek at riffle downstream } \\
\text { from pool }\end{array}$ & 39.67936 & -104.796 & 5,524 & TGH \\
\hline 394051104475901 & TG-976 & TG-976 stream site at $976 \mathrm{~m}$ & Stream & 6,306 & $\begin{array}{l}\text { West Toll Gate Creek at second foot bridge in } \\
\text { Horseshoe Park }\end{array}$ & 39.68095 & -104.8 & 5,516 & TGH \\
\hline 394052104480001 & TG-1001 & TG-1001 left-bank inflow at $1,001 \mathrm{~m}$ & LBI & 6,331 & Seepage area & 39.68108 & -104.8 & 5,503 & TGH \\
\hline 394055104480301 & TG-1118 & TG-1118 stream site at $1,118 \mathrm{~m}$ & Stream & 6,448 & $\begin{array}{l}\text { West Toll Gate Creek, } \approx 450 \mathrm{~m} \text { upstream from } \\
\text { Mexico Avenue }\end{array}$ & 39.68189 & -104.801 & 5,527 & TGH \\
\hline 394055104480302 & TG-1129 & TG-1129 left-bank inflow at $1,129 \mathrm{~m}$ & LBI & 6,459 & Cherry Creek Spillway tributary & 39.68195 & -104.801 & 5,509 & TGH \\
\hline 394107104481001 & TG-1536 & TG-1536 stream site at $1,536 \mathrm{~m}$ & Stream & 6,866 & $\begin{array}{l}\text { West Toll Gate Creek, } \approx 30 \mathrm{~m} \text { upstream from } \\
\text { Mexico Avenue }\end{array}$ & 39.68517 & -104.803 & 5,495 & TGH \\
\hline 394107104481101 & TG-1558 & TG-1558 left-bank inflow at $1,558 \mathrm{~m}$ & LBI & 6,888 & Inflow $\approx 10 \mathrm{~m}$ upstream from Mexico Avenue & 39.68531 & -104.803 & 5,488 & TGH \\
\hline 394107104481102 & TG-1584 & TG-1584 left-bank inflow at $1,584 \mathrm{~m}$ & LBI & 6,914 & Inflow inside left third (upstream) of a three & 39.68539 & -104.803 & & TGH \\
\hline
\end{tabular}
part box culvert 
[Site ID, U.S. Geological Survey site identification number; Sample ID, synoptic-sample identification number; TG, Toll Gate; WP, waypoint number assigned by Global Positioning System unit; LBI, leftbank inflow; RBI, right-bank inflow; TGH, Toll Gate Creek headwaters subreach; TGU, Toll Gate Creek upper subreach; TGM, Toll Gate Creek middle subreach; TGL, Toll Gate Creek lower subreach; m, meters; E., East; in., inch; $\approx$, approximately; ft., foot; m, meter]

\begin{tabular}{|c|c|c|c|c|c|c|c|c|c|}
\hline Site ID & Sample ID & Site Name & Source & $\begin{array}{l}\text { Distance } \\
\text { from Quincy } \\
\text { Reservoir } \\
\text { (meters) }\end{array}$ & Site Description & $\begin{array}{l}\text { Latitude } \\
\text { (decimal } \\
\text { degrees) }\end{array}$ & $\begin{array}{l}\text { Longitude } \\
\text { (decimal } \\
\text { degrees) }\end{array}$ & $\begin{array}{l}\text { Altitude } \\
\text { (feet) }\end{array}$ & Subreach \\
\hline 394107104481103 & TG-1585 & TG-1585 right-bank inflow at $1,585 \mathrm{~m}$ & RBI & 6,915 & $\begin{array}{l}\text { Inflow inside right third (downstream) of a } \\
\text { three part box culvert }\end{array}$ & 39.68539 & -104.803 & & $\mathrm{TGH}$ \\
\hline 394109104481201 & TG-1649 & TG-1649 left-bank inflow at $1,649 \mathrm{~m}$ & LBI & 6,979 & $\begin{array}{l}12 \text { in. culvert } \approx 12 \mathrm{~m} \text { downstream from } \\
\text { Mexico Avenue }\end{array}$ & 39.68597 & -104.803 & 5,489 & TGH \\
\hline 394112104481401 & TG-1748 & TG-1748 stream site at $1,748 \mathrm{~m}$ & Stream & 7,078 & TGU Transport Site \#0 & 39.68678 & -104.804 & 5,485 & $\begin{array}{l}\text { TGU, } \\
\text { TGH }\end{array}$ \\
\hline 394115104481501 & TG-1859 & TG-1859 left-bank inflow at $1,859 \mathrm{~m}$ & LBI & 7,189 & Former tributary now piped to culvert. & 39.68751 & -104.804 & 5,501 & TGU \\
\hline 394119104481801 & TG-1997 & TG-1997 stream site at $1,997 \mathrm{~m}$ & Stream & 7,327 & $\begin{array}{l}\text { West Toll Gate Creek, } \approx 170 \mathrm{~m} \text { downstream } \\
\text { from large drop structure }\end{array}$ & 39.68863 & -104.805 & 5,479 & $\begin{array}{l}\text { TGU, } \\
\text { TGH }\end{array}$ \\
\hline 394124104481801 & TG-2148 & TG-2148 stream site at $2,148 \mathrm{~m}$ & Stream & 7,478 & $\begin{array}{l}\text { West Toll Gate Creek } \approx 320 \mathrm{~m} \text { downstream } \\
\text { from large drop structure (TGU Transport } \\
\text { Site \#1) }\end{array}$ & 39.68996 & -104.805 & 5,470 & TGU \\
\hline 394124104481802 & TG-2165 & TG-2165 left-bank inflow at $2,165 \mathrm{~m}$ & LBI & 7,495 & Contact spring & 39.6901 & -104.805 & 5,484 & TGU \\
\hline 394130104481801 & TG-2346 & TG-2346 stream site at 2,346 m & Stream & 7,676 & $\begin{array}{l}\text { West Toll Gate Creek } \approx 570 \mathrm{~m} \text { upstream from } \\
\text { Mississippi Avenue }\end{array}$ & 39.69172 & -104.805 & 5,470 & TGU \\
\hline 394131104481801 & TG-2365 & TG-2365 left-bank inflow at $2,365 \mathrm{~m}$ & LBI & 7,695 & & 39.69189 & -104.805 & 5,489 & TGU \\
\hline 394134104481701 & TG-2452 & TG-2452 stream site at $2,452 \mathrm{~m}$ & Stream & 7,782 & $\begin{array}{l}\text { West Toll Gate Creek } \approx 470 \mathrm{~m} \text { upstream from } \\
\text { Mississippi Avenue }\end{array}$ & 39.69265 & -104.805 & 5,461 & TGU \\
\hline 394141104481901 & TG-2708 & TG-2708 stream site at $2,708 \mathrm{~m}$ & Stream & 8,038 & $\begin{array}{l}\text { West Toll Gate Creek } \approx 210 \mathrm{~m} \text { upstream from } \\
\text { Mississippi Avenue }\end{array}$ & 39.69469 & -104.805 & 5,465 & TGU \\
\hline 394146104482101 & TG-2893 & TG-2893 stream site at $2,893 \mathrm{~m}$ & Stream & 8,223 & $\begin{array}{l}\text { West Toll Gate Creek } \approx 25 \mathrm{~m} \text { upstream from } \\
\text { Mississippi Avenue (TGU Transport Site } \\
\# 2 \text { ) }\end{array}$ & 39.69621 & -104.806 & 5,463 & TGU \\
\hline 394153104482101 & TG-3114 & TG-3114 stream site at $3,114 \mathrm{~m}$ & Stream & 8,444 & $\begin{array}{l}\text { West Toll Gate Creek } \approx 120 \mathrm{~m} \text { downstream } \\
\text { from Mississippi Avenue }\end{array}$ & 39.69817 & -104.806 & 5,464 & TGU \\
\hline 394200104482101 & TG-3330 & TG-3330 stream site at $3,330 \mathrm{~m}$ & Stream & 8,660 & $\begin{array}{l}\text { West Toll Gate Creek } \approx 340 \mathrm{~m} \text { downstream } \\
\text { from Mississippi Avenue }\end{array}$ & 39.70011 & -104.806 & 5,474 & TGU \\
\hline 394205104482001 & TG-3466 & TG-3466 stream site at 3,466 m & Stream & 8,796 & $\begin{array}{l}\text { West Toll Gate Creek } \approx 470 \mathrm{~m} \text { downstream } \\
\text { from Mississippi Avenue }\end{array}$ & 39.70131 & -104.806 & 5,495 & TGU \\
\hline 394205104482002 & TG-3479 & TG-3479 left-bank inflow at 3,479 m & LBI & 8,809 & $\begin{array}{l}\text { Large cement culvert. Likely former tributary } \\
\text { piped to culvert. }\end{array}$ & 39.70142 & -104.806 & 5,498 & TGU \\
\hline 394210104482001 & TG-3627 & TG-3627 stream site at $3,627 \mathrm{~m}$ & Stream & 8,957 & $\begin{array}{l}\text { West Toll Gate Creek } \approx 660 \mathrm{~m} \text { upstream from } \\
\text { Alameda Avenue (TGU Transport Site \#3) }\end{array}$ & 39.70275 & -104.806 & 5,470 & TGU \\
\hline 394210104482002 & TG-3641 & TG-3641 right-bank inflow at $3,641 \mathrm{~m}$ & RBI & 8,971 & & 39.70286 & -104.806 & 5,469 & TGU \\
\hline
\end{tabular}


Table 2. Site information for stream and inflow synoptic-sampling sites, Toll Gate Creek, July-August 2007.—Continued

[Site ID, U.S. Geological Survey site identification number; Sample ID, synoptic-sample identification number; TG, Toll Gate; WP, waypoint number assigned by Global Positioning System unit; LBI, leftbank inflow; RBI, right-bank inflow; TGH, Toll Gate Creek headwaters subreach; TGU, Toll Gate Creek upper subreach; TGM, Toll Gate Creek middle subreach; TGL, Toll Gate Creek lower subreach; m, meters; E., East; in., inch; $\approx$, approximately; ft., foot; m, meter]

\begin{tabular}{|c|c|c|c|c|c|c|c|c|c|}
\hline Site ID & Sample ID & Site Name & Source & $\begin{array}{l}\text { Distance } \\
\text { from Quincy } \\
\text { Reservoir } \\
\text { (meters) }\end{array}$ & Site Description & $\begin{array}{l}\text { Latitude } \\
\text { (decimal } \\
\text { degrees) }\end{array}$ & $\begin{array}{l}\text { Longitude } \\
\text { (decimal } \\
\text { degrees) }\end{array}$ & $\begin{array}{l}\text { Altitude } \\
\text { (feet) }\end{array}$ & Subreach \\
\hline 394218104482101 & TG-3897 & TG-3897 stream site at $3,897 \mathrm{~m}$ & Stream & 9,227 & $\begin{array}{l}\text { West Toll Gate Creek } \approx 20 \mathrm{~m} \text { downstream } \\
\text { from large drop structure }\end{array}$ & 39.70501 & -104.806 & 5,515 & TGU \\
\hline 394223104482201 & TG-4086 & TG-4086 stream site at $4,086 \mathrm{~m}$ & Stream & 9,416 & $\begin{array}{l}\text { West Toll Gate Creek } \approx 210 \mathrm{~m} \text { downstream } \\
\text { from large drop structure }\end{array}$ & 39.70645 & -104.806 & 5,498 & TGU \\
\hline 394223104482202 & TG-4087 & TG-4087 left-bank inflow at $4,087 \mathrm{~m}$ & LBI & 9,417 & & 39.70645 & -104.806 & 5,480 & TGU \\
\hline 394227104482101 & TG-4216 & TG-4216 stream site at $4,216 \mathrm{~m}$ & Stream & 9,546 & $\begin{array}{l}\text { West Toll Gate Creek } \approx 70 \mathrm{~m} \text { upstream from } \\
\text { Alameda Avenue }\end{array}$ & 39.70759 & -104.806 & 5,463 & TGU \\
\hline 394230104482001 & TG-4268 & TG-4268 right-bank inflow at $4,268 \mathrm{~m}$ & RBI & 9,598 & $\begin{array}{l}\text { Inflow on upstream side of the Alameda } \\
\text { Parkway bridge }\end{array}$ & 39.70829 & -104.806 & 5,475 & TGU \\
\hline 394231104482001 & TGM-4361 & TG-4361 stream site at $4,361 \mathrm{~m}$ & Stream & 9,691 & $\begin{array}{l}\text { TGU Transport Site \#4 } \\
\text { TGM Transport Site \#0 }\end{array}$ & 39.70871 & -104.805 & 5,462 & $\begin{array}{l}\text { TGM, } \\
\text { TGU }\end{array}$ \\
\hline 394242104481801 & TGM-4695 & TG-4695 stream site at $4,695 \mathrm{~m}$ & Stream & 10,025 & TGM Transport Site \#1 & 39.71159 & -104.805 & 5,445 & $\begin{array}{l}\text { TGM, } \\
\text { TGU }\end{array}$ \\
\hline 394243104481701 & TGM-4723 & TG-4723 right-bank inflow at $4,723 \mathrm{~m}$ & RBI & 10,053 & Contact spring & 39.71185 & -104.805 & 5,492 & TGM \\
\hline 394244104481901 & TGM-4820 & TG-4820 stream site at $4,820 \mathrm{~m}$ & Stream & 10,150 & $\begin{array}{l}\text { West Toll Gate Creek, } \approx 800 \mathrm{~m} \text { upstream from } \\
\text { Chambers Road bridge }\end{array}$ & 39.71224 & -104.805 & 5,475 & TGM \\
\hline 394243104482801 & TGM-5075 & TG-5075 stream site at $5,075 \mathrm{~m}$ & Stream & 10,405 & $\begin{array}{l}\text { West Toll Gate Creek, } \approx 540 \mathrm{~m} \text { upstream from } \\
\text { Chambers Road bridge }\end{array}$ & 39.71204 & -104.808 & 5,469 & TGM \\
\hline 394247104483301 & TGM-5301 & TG-5301 stream site at $5,301 \mathrm{~m}$ & Stream & 10,631 & $\begin{array}{l}\text { West Toll Gate Creek, under footbridge at } \\
\text { DeLaney Farm }\end{array}$ & 39.71292 & -104.809 & 5,452 & TGM \\
\hline 394254104483501 & TGM-5617 & TG-5617 stream site at $5,617 \mathrm{~m}$ & Stream & 10,947 & $\begin{array}{l}\text { West Toll Gate Creek at upstream edge of } \\
\text { Chambers Road bridge }\end{array}$ & 39.71502 & -104.81 & 5,462 & TGM \\
\hline 394302104483901 & TGM-5928 & TG-5928 stream site at $5,928 \mathrm{~m}$ & Stream & 11,258 & $\begin{array}{l}\text { West Toll Gate Creek, } \approx 300 \mathrm{~m} \text { downstream } \\
\text { from Chambers Road bridge }\end{array}$ & 39.71724 & -104.811 & 5,470 & TGM \\
\hline 394308104484101 & TGM-6111 & TG-6111 stream site at $6,111 \mathrm{~m}$ & Stream & 11,441 & $\begin{array}{l}\text { West Toll Gate Creek (TGM Transport Site } \\
\text { \#2) }\end{array}$ & 39.71882 & -104.811 & 5,466 & TGM \\
\hline 394310104484501 & TGM-6348 & TG-6348 stream site at $6,348 \mathrm{~m}$ & Stream & 11,678 & $\begin{array}{l}\text { West Toll Gate Creek, } \approx 700 \mathrm{~m} \text { downstream } \\
\text { from Chambers Road bridge }\end{array}$ & 39.71931 & -104.813 & 5,420 & TGM \\
\hline 394310104484601 & TGM-6373 & TG-6373 left-bank inflow at $6,373 \mathrm{~m}$ & LBI & 11,703 & $\approx 4 \mathrm{ft}$ culvert near Dearborn Street & 39.71952 & -104.813 & 5,433 & TGM \\
\hline 394313104484301 & TGM-6531 & TG-6531 stream site at $6,531 \mathrm{~m}$ & Stream & 11,861 & $\begin{array}{l}\text { West Toll Gate Creek at narrow constriction } \\
\text { under streamside cottonwood trees }\end{array}$ & 39.72037 & -104.812 & 5,456 & TGM \\
\hline 394314104484801 & TGM-6854 & TG-6854 stream site at $6,854 \mathrm{~m}$ & Stream & 12,184 & $\begin{array}{l}\text { West Toll Gate Creek } \approx 140 \mathrm{~m} \text { upstream from } \\
\text { confluence with East Toll Gate }\end{array}$ & 39.72068 & -104.813 & 5,409 & TGM \\
\hline
\end{tabular}


[Site ID, U.S. Geological Survey site identification number; Sample ID, synoptic-sample identification number; TG, Toll Gate; WP, waypoint number assigned by Global Positioning System unit; LBI, leftbank inflow; RBI, right-bank inflow; TGH, Toll Gate Creek headwaters subreach; TGU, Toll Gate Creek upper subreach; TGM, Toll Gate Creek middle subreach; TGL, Toll Gate Creek lower subreach; m, meters; E., East; in., inch; $\approx$, approximately; ft., foot; m, meter]

\begin{tabular}{|c|c|c|c|c|c|c|c|c|c|}
\hline Site ID & Sample ID & Site Name & Source & $\begin{array}{l}\text { Distance } \\
\text { from Quincy } \\
\text { Reservoir } \\
\text { (meters) }\end{array}$ & Site Description & $\begin{array}{l}\text { Latitude } \\
\text { (decimal } \\
\text { degrees) }\end{array}$ & $\begin{array}{l}\text { Longitude } \\
\text { (decimal } \\
\text { degrees) }\end{array}$ & $\begin{array}{l}\text { Altitude } \\
\text { (feet) }\end{array}$ & Subreach \\
\hline 394314104485201 & TGM-6982 & TG-6982 stream site at $6,982 \mathrm{~m}$ & Stream & 12,312 & $\begin{array}{l}\text { West Toll Gate Creek } \approx 10 \mathrm{~m} \text { upstream from } \\
\text { confluence with East Toll Gate }\end{array}$ & 39.7205 & -104.814 & & TGM \\
\hline 394314104485202 & TGM-6993 & TG-6993 right-bank inflow at $6,993 \mathrm{~m}$ & RBI & 12,323 & East Toll Gate Creek & 39.72051 & -104.815 & 5,390 & TGM \\
\hline 394314104485601 & TGM-7098 & TG-7098 stream site at 7,098 m & Stream & 12,428 & $\begin{array}{l}\text { Toll Gate Creek } \approx 100 \mathrm{~m} \text { downstream from } \\
\text { confluence of East and West Toll Gate } \\
\text { (TGM Transport Site \#3) }\end{array}$ & 39.72067 & -104.816 & 5,410 & TGM \\
\hline 394317104485501 & TGM-7214 & TG-7214 stream site at 7,214 m & Stream & 12,544 & Toll Gate Creek downstream from riffles & 39.72144 & -104.815 & 5,379 & TGM \\
\hline 394323104485801 & TGM-7447 & TG-7447 stream site at $7,447 \mathrm{~m}$ & Stream & 12,777 & $\begin{array}{l}\text { Toll Gate Creek downstream from 3-4 ft high } \\
\text { dam }\end{array}$ & 39.72298 & -104.816 & 5,427 & TGM \\
\hline 394323104490201 & TGM-7560 & TG-7560 left-bank inflow at 7,560 m & LBI & 12,890 & & 39.72314 & -104.817 & 5,398 & TGM \\
\hline 394330104490501 & TGM-7818 & TG-7818 stream site at $7,818 \mathrm{~m}$ & Stream & 13,148 & $\begin{array}{l}\text { Toll Gate Creek just upstream from 6th } \\
\text { Avenue (TGM Transport Site \#4; Stream } \\
\text { gage for Urban Drainage and Flood Con- } \\
\text { trol District, Device \#703) }\end{array}$ & 39.72512 & -104.818 & 5,427 & TGM \\
\hline 394332104490701 & TGM-7890 & TG-7890 left-bank inflow at 7,890 m & LBI & 13,220 & $\begin{array}{l}\approx 4 \mathrm{ft} \text { culvert at downstream side of } 6 \mathrm{th} \mathrm{Av}- \\
\text { enue. Former tributary piped to culvert. }\end{array}$ & 39.72568 & -104.819 & 5,417 & TGM \\
\hline 394336104490501 & TGM-8011 & TG-8011 stream site at $8,011 \mathrm{~m}$ & Stream & 13,341 & $\begin{array}{l}\text { Toll Gate Creek } \approx 130 \mathrm{~m} \text { downstream from } \\
\text { 6th Avenue }\end{array}$ & 39.72673 & -104.818 & 5,402 & $\begin{array}{l}\text { TGL, } \\
\text { TGM }\end{array}$ \\
\hline 394343104491101 & TGM-8281 & TG-8281 stream site at $8,281 \mathrm{~m}$ & Stream & 13,611 & & 39.72864 & -104.82 & 5,417 & $\begin{array}{l}\text { TGL, } \\
\text { TGM }\end{array}$ \\
\hline 394348104491801 & TG-8538 & TG-8538 stream site at $8,538 \mathrm{~m}$ & Stream & 13,868 & Toll Gate Creek at Aurora Meadows bridge & 39.73009 & -104.822 & 5,389 & TGL \\
\hline 394355104491901 & TG-8794 & TG-8794 stream site at $8,794 \mathrm{~m}$ & Stream & 14,124 & $\begin{array}{l}\text { Toll Gate Creek, } \approx 330 \mathrm{~m} \text { upstream from } \\
\text { I- } 225 \text { bridge }\end{array}$ & 39.73195 & -104.33822 & 5,412 & TGL \\
\hline 394359104493001 & TG-9129 & TG-9129 stream site at 9,129 m & Stream & 14,459 & $\begin{array}{l}\text { Toll Gate Creek at upstream side of I-225 } \\
\text { bridge (TGL Transport Site \#0) }\end{array}$ & 39.73303 & -104.825 & 5,418 & TGL \\
\hline 394406104493501 & TG-9408 & TG-9408 stream site at $9,408 \mathrm{~m}$ & Stream & 14,738 & $\begin{array}{l}\text { Toll Gate Creek, } \approx 300 \text { m downstream from } \\
\text { I-225 bridge (TGL Transport Site \#1) }\end{array}$ & 39.73503 & -104.826 & 5,415 & TGL \\
\hline 394414104493401 & TG-9673 & TG-9673 stream site at $9,673 \mathrm{~m}$ & Stream & 15,003 & $\begin{array}{l}\text { Toll Gate Creek, } \approx 550 \text { m downstream from } \\
\text { I- } 225 \text { bridge }\end{array}$ & 39.73719 & -104.826 & 5,401 & TGL \\
\hline 394423104493501 & TG-9971 & TG-9971 stream site at 9,971 m & Stream & 15,301 & $\begin{array}{l}\text { Toll Gate Creek, } \approx 30 \mathrm{~m} \text { upstream from } \\
\text { Colfax Avenue }\end{array}$ & 39.73984 & -104.826 & 5,375 & TGL \\
\hline 394424104493501 & TG-9989 & TG-9989 right-bank inflow at 9,989 m & RBI & 15,319 & $\begin{array}{l}\text { Box culvert, } \approx 10 \mathrm{~m} \text { upstream from Colfax } \\
\quad \text { Avenue }\end{array}$ & 39.73997 & -104.826 & 5,384 & TGL \\
\hline
\end{tabular}


Table 2. Site information for stream and inflow synoptic-sampling sites, Toll Gate Creek, July-August 2007.—Continued

[Site ID, U.S. Geological Survey site identification number; Sample ID, synoptic-sample identification number; TG, Toll Gate; WP, waypoint number assigned by Global Positioning System unit; LBI, leftbank inflow; RBI, right-bank inflow; TGH, Toll Gate Creek headwaters subreach; TGU, Toll Gate Creek upper subreach; TGM, Toll Gate Creek middle subreach; TGL, Toll Gate Creek lower subreach; m, meters; E., East; in., inch; $\approx$, approximately; ft., foot; m, meter]

\begin{tabular}{|c|c|c|c|c|c|c|c|c|c|}
\hline Site ID & Sample ID & Site Name & Source & $\begin{array}{l}\text { Distance } \\
\text { from Quincy } \\
\text { Reservoir } \\
\text { (meters) }\end{array}$ & Site Description & $\begin{array}{l}\text { Latitude } \\
\text { (decimal } \\
\text { degrees) }\end{array}$ & $\begin{array}{l}\text { Longitude } \\
\text { (decimal } \\
\text { degrees) }\end{array}$ & $\begin{array}{l}\text { Altitude } \\
\text { (feet) }\end{array}$ & Subreach \\
\hline 394432104493601 & TG-10236 & TG-10236 stream site at $10,236 \mathrm{~m}$ & Stream & 15,566 & $\begin{array}{l}\text { Toll Gate Creek, } \approx 200 \mathrm{~m} \text { downstream from } \\
\text { Colfax Avenue bridge }\end{array}$ & 39.74212 & -104.827 & 5,366 & TGL \\
\hline 394432104493602 & TG-10242 & TG-10242 right-bank inflow at $10,242 \mathrm{~m}$ & RBI & 15,572 & & 39.74216 & -104.827 & 5,347 & TGL \\
\hline 394439104494001 & TG-10497 & TG-10497 stream site at $10,497 \mathrm{~m}$ & Stream & 15,827 & $\begin{array}{l}\text { Toll Gate Creek, } \approx 10 \mathrm{~m} \text { upstream from } \\
\text { Wilderman Place/Fitzsimons Way bridge } \\
\text { (TGL Transport Site \#2) }\end{array}$ & 39.74429 & -104.828 & 5,310 & TGL \\
\hline 394441104493901 & TG-10557 & TG-10557 right-bank inflow at $10,557 \mathrm{~m}$ & RBI & 15,887 & Contact spring & 39.74481 & -104.828 & 5,289 & TGL \\
\hline 394446104494201 & TG-10716 & TG-10716 stream site at $10,716 \mathrm{~m}$ & Stream & 16,046 & $\begin{array}{l}\text { Toll Gate Creek, } \approx 200 \mathrm{~m} \text { downstream from } \\
\text { Wilderman Place/Fitzsimons Way bridge }\end{array}$ & 39.74607 & -104.828 & 5,303 & TGL \\
\hline 394455104494201 & TG-10993 & TG-10993 stream site at $10,993 \mathrm{~m}$ & Stream & 16,323 & $\begin{array}{l}\text { Toll Gate Creek at narrow constriction with } \\
\text { claystone bedrock }\end{array}$ & 39.74848 & -104.828 & 5,310 & TGL \\
\hline 394502104494401 & TG-11228 & TG-11228 stream site at $11,228 \mathrm{~m}$ & Stream & 16,558 & $\begin{array}{l}\text { Toll Gate Creek, } \approx 700 \mathrm{~m} \text { downstream from } \\
\text { Wilderman Place/Fitzsimons Way bridge }\end{array}$ & 39.75048 & -104.829 & 5,325 & TGL \\
\hline 394502104494402 & TG-11246 & TG-11246 right-bank inflow at $11,246 \mathrm{~m}$ & RBI & 16,576 & Contact spring/seep & 39.75064 & -104.829 & 5,306 & TGL \\
\hline 394504104494401 & TG-11292 & TG-11292 right-bank inflow at $11,292 \mathrm{~m}$ & RBI & 16,622 & & 39.75105 & -104.829 & 5,312 & TGL \\
\hline 394504104494402 & TG-11312 & TG-11312 stream site at $11,312 \mathrm{~m}$ & Stream & 16,642 & $\begin{array}{l}\text { Toll Gate Creek at narrow constriction (TGL } \\
\text { Transport Site \#3) }\end{array}$ & 39.75122 & -104.829 & & TGL \\
\hline 394505104494401 & TG-11326 & TG-11326 right-bank inflow at 11,326 m & RBI & 16,656 & & 39.75132 & -104.829 & 5,319 & TGL \\
\hline 394507104495001 & TG-11473 & TG-11473 stream site at $11,473 \mathrm{~m}$ & Stream & 16,803 & Toll Gate Creek & 39.75188 & -104.831 & 5,321 & TGL \\
\hline 394509104495301 & TG-11570 & TG-11570 left-bank inflow at $11,570 \mathrm{~m}$ & LBI & 16,900 & & 39.75236 & -104.831 & 5,308 & TGL \\
\hline 394516104495801 & TG-11835 & TG-11835 stream site at $11,835 \mathrm{~m}$ & Stream & 17,165 & Toll Gate Creek & 39.75449 & -104.833 & 5,315 & TGL \\
\hline 394520104500901 & TG-12164 & TG-12164 stream site at $12,164 \mathrm{~m}$ & Stream & 17,494 & $\begin{array}{l}\text { Toll Gate Creek under foot bridge, } \approx 200 \\
\text { m upstream from confluence with Sand } \\
\text { Creek (TGL Transport Site \#4) }\end{array}$ & 39.75568 & -104.836 & 5,359 & TGL \\
\hline
\end{tabular}


Table 3. Water-quality constituents analyzed for surface-water and groundwater samples, Toll Gate Creek, July-August 2007.

[Detection level is the concentration below which the analyte is considered not detected. Reporting level is the concentration at which the analyte is censored (given a less than value) if it is below the detection level. Values between the detection level and the reporting level are coded with an "E" value. $\mathrm{mg} / \mathrm{L}$, milligrams per liter; lab, laboratory; $\mathrm{CaCO}_{3}$, calcium carbonate; na, not applicable; $\mu \mathrm{S} / \mathrm{cm}$, microSiemens per centimeter at $25 \mathrm{degrees} \mathrm{Celsius;} \mu \mathrm{g} / \mathrm{L}$, micrograms per liter; $\mathrm{SiO}_{2}$, silica; $\mathrm{N}$, nitrogen; $\mathrm{TU}$, tritium units]

\begin{tabular}{|c|c|c|c|}
\hline Constituent & Detection level & Reporting level & $\begin{array}{l}\text { Sampled in groundwater, } \\
\text { surface water, or both }\end{array}$ \\
\hline \multicolumn{4}{|c|}{ Physical properties, in units as noted } \\
\hline $\mathrm{pH}$, field, in standard units & na & na & Both \\
\hline Specific conductance, field, in $\mu \mathrm{S} / \mathrm{cm}$ & 2.6 & 2.6 & Both \\
\hline Water temperature, in degrees Celsius & na & na & Both \\
\hline \multicolumn{4}{|c|}{ Major ions, in milligrams per liter unless noted } \\
\hline Calcium, filtered & 0.01 & 0.02 & Both \\
\hline Calcium, unfiltered & 0.007 & 0.014 & Surface water \\
\hline Magnesium, filtered & 0.007 & 0.014 & Both \\
\hline Magnesium, unfiltered & 0.001 & 0.002 & Surface water \\
\hline Chloride, filtered & 0.06 & 0.12 & Both \\
\hline Sulfate, filtered & 0.09 & 0.18 & Both \\
\hline Fluoride, filtered & 0.05 & 0.1 & Both \\
\hline Bromide, filtered & 0.01 & 0.02 & Both \\
\hline Silica, filtered, in $\mathrm{mg} / \mathrm{L}$ as $\mathrm{SiO}_{2}$ & 0.009 & 0.018 & Both \\
\hline Total dissolved solids, filtered & 10 & 10 & Both \\
\hline \multicolumn{4}{|c|}{ Trace elements, in micrograms per liter } \\
\hline Aluminum, filtered & 0.8 & 1.6 & Both \\
\hline Aluminum, unfiltered & 1 & 2 & Surface water \\
\hline Iron, filtered & 3 & 6 & Both \\
\hline Zinc, filtered & 0.3 & 0.6 & Both \\
\hline Zinc, unfiltered & 1.0 & 2.0 & Surface water \\
\hline \multicolumn{4}{|c|}{ Nutrients, in milligrams per liter } \\
\hline Ammonia, as $\mathrm{N}$, filtered & 0.01 & 0.02 & Both \\
\hline Nitrite, as $\mathrm{N}$, filtered & 0.001 & 0.002 & Both \\
\hline Nitrite plus nitrate, as $\mathrm{N}$, filtered & 0.03 & 0.06 & Both \\
\hline Total nitrogen, unfiltered & 0.03 & 0.06 & Both \\
\hline Total phosphorous, unfiltered & 0.004 & 0.008 & Both \\
\hline Orthophosphate, filtered & 0.003 & 0.006 & Both \\
\hline \multicolumn{4}{|c|}{ Other constituents, in units as noted } \\
\hline${ }^{2} \mathrm{H}-{ }^{1} \mathrm{H}$ ratio, per mil & na & na & Both \\
\hline${ }^{18} \mathrm{O}-{ }^{16} \mathrm{O}$ ratio, per mil & na & na & Both \\
\hline Tritium, in TU & 1,000 & 1.000 & Groundwater \\
\hline Dissolved organic carbon, in $\mathrm{mg} / \mathrm{L}$ & 0.2 & 0.4 & Groundwater \\
\hline Dissolved gases, in $\mathrm{mg} / \mathrm{L}$ & na & na & Groundwater \\
\hline Chlorofluorocarbons, in picomoles per kilogram & na & na & Groundwater \\
\hline
\end{tabular}


Concentrations of orthophosphate and ammonia, nitrite, and nitrite plus nitrate as nitrogen were determined from filtered samples using colorimetry (Fishman, 1993). Total nitrogen and phosphorous were determined from unfiltered aliquots that were digested with alkaline persulfate. Nitrogen and phosphorous were determined with a two-channel photometric, air-segmented continuous flow analyzer (Patton and Kryskalla, 2003).

Unfiltered samples for analysis of stable-isotope ratios of hydrogen $\left({ }^{2} \mathrm{H}\right.$ and ${ }^{1} \mathrm{H}$, hereinafter abbreviated as $\left.\delta^{2} \mathrm{H}\right)$ and oxygen $\left({ }^{18} \mathrm{O}\right.$ and ${ }^{16} \mathrm{O}$, hereinafter abbreviated as $\left.\delta^{18} \mathrm{O}\right)$ relative to Vienna Standard Mean Ocean Water were collected in clear glass bottles and analyzed at the USGS Reston Stable Isotope Laboratory (RSIL) in Reston, Va. Hydrogen-isotope ratios were analyzed using the gaseous hydrogen equilibration procedure (Coplen and others, 1991). Oxygen-isotope ratios were determined from the carbon dioxide-water equilibration technique of Epstein and Mayeda (1953) (http://isotopes. usgs.gov/Quality.htm\#samples, accessed March 20, 2008). Methods used to calculate evaporative concentration of water samples based on isotope ratios are presented in the "Hydrogen and Oxygen Isotope Ratios as Indicators of Evaporation" section of this report.

Filtered, unacidified aliquots from synoptic samples were analyzed for the bromide tracer using ion chromatography at the USGS laboratory in Salt Lake City, Utah (Brinton and others, 1996). Additional samples collected to document the presence (or absence) of a steady-state tracer plateau (a time series of samples collected at a subset of stream sites) also were analyzed for bromide at the USGS laboratory in Salt Lake City as were presynoptic samples used to determine ambient bromide concentrations. Methods and quality-assurance procedures used for bromide analysis are described in Kimball and others (1999).

\section{Surface-Water Mass-Loading Calculations}

Streamflow estimates were combined with synopticsampling results to compute mass-loading graphs for constituents of interest. Under the synoptic mass-balance approach (Kimball and others, 2002, 2007), the sampled instream load (M) is the constituent load at the downstream end of a stream segment and is defined as the product of constituent concentration and streamflow:

$$
\mathrm{M}=\mathrm{CQ}
$$

where $\mathrm{M}$ is sampled instream load (mass/time), $\mathrm{C}$ is instream concentration (mass/volume), Q is streamflow (volume/time), and $\mathrm{C}$ and $\mathrm{Q}$ and are in consistent units $(\mathrm{C}$ in milligrams per liter and $\mathrm{Q}$ in liters per second, for example). Values of $\mathrm{C}$ used in this report correspond to dissolved constituent concentrations. The sampled instream load of a stream segment includes the load from the upstream end plus the load contributed by all surface and subsurface inflows between two encompassing stream sites. The sampled instream load represents the effects of changing streamflow, constituent source, and geochemical reactions occurring in the stream.
For the Toll Gate Creek dataset, spatial profiles of sampled instream load (M) were developed using constituent concentrations and the final streamflow estimates developed in Appendix 1. These spatial profiles were then used to interpret the general loading patterns of constituent mass within Toll Gate Creek for selenium, calcium, magnesium, sodium, sulfate, chloride, and uranium. The spatial resolution of constituent concentrations was insufficient to interpret loading profiles for nutrients.

\section{Multivariate and Linear Correlation Analysis}

An important objective of synoptic sampling is to recognize patterns or chemical characteristics among samples that can help identify the various sources and sinks of solutes. As water interacts with different mineral assemblages or is affected by human activities, it obtains a distinct chemical signature. A method of cluster analysis called partitioning around medoids was used to evaluate distinctions among the samples (Kauffman and Rousseeuw, 1990). The method operates by computing the Euclidian distance among samples as a measure of similarity. Each sample is then assigned to the cluster of the nearest medoid, a type of multivariate median for a group of samples. Choosing the number of groups for inflows and stream sites was guided by the ability to explain a grouping in terms of geologic, hydrologic, or geochemical information. Any cluster that could not be explained in relatively simple physical or chemical terms was not added.

To emphasize linear relations derived from mass balance of dissolving minerals and possible controls from chemical equilibria, the data were converted to units of millimoles per liter and then log transformed. These transformed concentrations were converted to standard normal variables for the cluster analysis by subtracting the mean (of each log-transformed data distribution) from each log-transformed data value and dividing the result by the standard deviation (of each logtransformed data distribution) to give an equal weighting to major and trace elements. Principal components also were determined using these data to identify groups of constituents with meaningful covariation.

Measures of correlation between variables (linear correlation coeffcients or Pearson's r) were determined from linear regression (Helsel and Hirsch, 2002). Linear correlation coefficients, which measure the linear association between variables, are dimensionless and are scaled to lie in the range greater than or equal to -1 and less than or equal to 1. Correlation coefficients greater than zero indicate that as one variable increases so does the correlated variable, and correlation coefficients less than zero indicate that as one variable increases the correlated variable decreases. The greater the absolute value of the correlation coefficient, the stronger the correlation. There is no correlation between two variables when the correlation coefficient is zero. The significance of a correlation is evaluated using a t-distribution statistical test to determine whether the linear correlation coefficient differs from zero, and the p-value is a measure of the significance. Results are generally considered significant when $\mathrm{p}$-values less than 0.1 . 


\section{Groundwater Sample Collection, Processing, and Analytical Methods}

Groundwater samples from 19 existing monitoring wells in the study area (table 4) were collected, processed, and analyzed. Three of the wells (URLUS-18, URLUS-28, and URLUS-30) were established in 2003 by the USGS as part of the National Water Quality Assessment Program (NAWQA) Urban Land-Use Study (URLUS) (http://co.water.usgs.gov/ nawqa/splt/html/spgwurbandata.html). The other 16 wells were installed in 2005 by the City of Aurora as part of a lawnirrigation return-flow study (Richard Vidmar, City of Aurora, oral commun., 2007). Sixteen of the 19 wells are completed in surficial materials, two of the wells are completed in surficial materials and weathered Denver Formation claystone, and one well is completed in surficial materials and weathered Denver Formation sandstone. Well purging, sample collection, field measurements, and equipment cleaning methods followed standard USGS protocols (Koterba and others, 1995; Lapham and others, 1995; U.S. Geological Survey, variously dated).

Groundwater samples were analyzed for physical properties, major ions, trace elements, nutrients, hydrogen and oxygen stable-isotope ratios, tritium, dissolved organic carbon (DOC), dissolved gases, and chlorofluorocarbons (CFCs) (table 3). Water temperature, depth to water, turbidity, $\mathrm{SC}, \mathrm{pH}$, alkalinity (by titration), and dissolved oxygen were determined in the field at the time of sample collection following standard USGS sampling protocols (U.S. Geological Survey, variously dated). Filtration, sample preservation, and laboratory analysis were consistent for all analytes common to both surface-water and groundwater samples (table 3) as previously described in the "Surface-Water Sample Processing and Analysis" section of this report. Potassium concentrations were determined using ICP-AES described in Standard Method 3120 (American Public Health Association, 1998). Unfiltered groundwater samples for tritium analyses were collected and stored in high-density polyethylene bottles and analyzed by the USGS Isotope Tracers Laboratory in Menlo Park, Calif., using electrolytic enrichment and analysis by liquid scintillation counting (Thatcher and others, 1977).

Samples for analysis of DOC were filtered, acidified to $\mathrm{pH}$ less than 2 using $4.5 \mathrm{~N}$ sulfuric acid, and chilled in amber glass bottles for transport to NWQL. The DOC content was analyzed by oxidizing samples to carbon dioxide using persulfate in the presence of ultraviolet light and quantifying carbon dioxide using nondispersive infrared spectrometry (Brenton and Arnett, 1993).

Groundwater ages are estimated for samples collected by this study using measured concentrations of dissolved gases, CFCs, and tritium $\left({ }^{3} \mathrm{H}\right)$ in water compared to historical concentrations in the atmosphere (Plummer and Busenberg, 1999; Böhlke, J.K., U.S. Geological Survey, written commun., 2006; Steven Phillips, U.S. Geological Survey, written commun., 2010). Dissolved gas analysis included oxygen $\left(\mathrm{O}_{2}\right)$, carbon dioxide $\left(\mathrm{CO}_{2}\right)$, nitrogen $\left(\mathrm{N}_{2}\right)$, and argon $(\mathrm{Ar})$ as indicators of recharge temperature and were analyzed using gas chromatography (http://water.usgs.gov/lab/dissolved-gas/ lab/analytical procedures/, accessed March 20, 2008), and CFCs were analyzed using purge-and-trap gas chromatography with an electron capture detector (http://water.usgs.gov/ lab/chlorofluorocarbons/lab/analytical_procedures/, accessed March 20, 2008). Samples for dissolved gas and CFCs were analyzed at the USGS CFC Laboratory in Reston, Va. Field collection procedures for dissolved gas and CFC sample aliquots are detailed on the Web sites referenced in this paragraph. Unfiltered samples for tritium analyses were collected and stored in high-density polyethylene bottles and analyzed by the USGS Isotope Tracers Laboratory in Menlo Park, Calif., using electrolytic enrichment and analysis by liquid scintillation counting (Thatcher and others, 1977). Methods used to estimate apparent groundwater ages from the dissolved gas, $\mathrm{CFC}$, and tritium concentration data are presented in the "Apparent Groundwater Ages and Recharge Rates" section of this report.

\section{Solids-Sampling and Analytical Methods}

Previous studies of geologic materials in the Toll Gate Creek watershed (Herring and Walton-Day, 2007) indicate claystone bedrock of the Denver Formation contains elevated concentrations of water-soluble selenium and is a likely source of selenium in surface water and groundwater. Additional solids samples were analyzed during this study to further examine the vertical distribution of potential selenium sources in the stratigraphic column. Samples of subsurface geologic materials were obtained from core samples for 5-ft intervals below land surface at well ET-1. The core samples were collected from the subsurface using a core barrel through hollowstem augers at the time of well installation in 2005, and the samples were provided to this study by the City of Aurora (Richard Vidmar, City of Aurora, oral commun., 2007). Well ET-1was selected for solids analysis because (1) an elevated selenium concentration was observed in the groundwater sample collected from the well $(49 \mu \mathrm{g} / \mathrm{L}) ;(2)$ the borehole penetrates both alluvial material and weathered claystone bedrock material representative of geologic conditions present beneath much of the watershed; and (3) well ET-1 is centrally located within the study area.

Solids samples were crushed and sieved to minus 100-mesh (less than 150 micrometers) according to methods described in Taylor and Theodorakos (2002). Varying ratios of sample to deionized water were mixed according to consistent endpoint saturation criteria to obtain a saturated paste extraction as described in Burt (2004). Solids samples were prepared by Bureau of Reclamation laboratories in Lakewood, Colo. Specific conductance and $\mathrm{pH}$ of the extracted solutions were measured immediately following extraction and the percent saturation (the weight of water divided by the dry weight of sample extracted times 100) was calculated for each sample (Burt, 2004). Filtered, acidified paste-extraction (aqueous) samples were analyzed at the NWQL for aluminum, barium, manganese, strontium, and uranium by ICP-MS (Faires, 1993); for arsenic and selenium by collision/reaction cell ICP-MS 
Table 4. Location and completion information for sampled groundwater monitoring wells, Toll Gate Creek, July-August 2007.

[Site ID, U.S. Geological Survey site identification number; NAD83, North American Datum of 1983; depths and intervals in feet below land surface]

\begin{tabular}{|c|c|c|c|c|c|c|c|c|c|}
\hline Site ID & Well name & $\begin{array}{l}\text { Latitude (NAD83 } \\
\text { decimal degrees) }\end{array}$ & $\begin{array}{l}\text { Longitude (NAD83 } \\
\text { decimal degrees) }\end{array}$ & $\begin{array}{l}\text { Land surface } \\
\text { altitude } \\
\text { (feet) }\end{array}$ & $\begin{array}{l}\text { Well depth } \\
\text { (feet) }\end{array}$ & $\begin{array}{c}\text { Screened } \\
\text { interval depth } \\
\text { (feet) }\end{array}$ & $\begin{array}{l}\text { Sample } \\
\text { date }\end{array}$ & $\begin{array}{c}\text { Depth to water } \\
\text { on sample date } \\
\text { (feet) }\end{array}$ & $\begin{array}{c}\text { Water-table altitude } \\
\text { on sample date } \\
\text { (feet) }\end{array}$ \\
\hline 394305104482601 & ET-1 & 39.71806 & -104.80722 & 5,423 & 24.0 & $14.0-24.0$ & $7 / 30 / 2007$ & 12.1 & $5,410.9$ \\
\hline 394305104482301 & ET-2 & 39.71806 & -104.80639 & 5,425 & 27.0 & $17.0-27.0$ & $7 / 16 / 2007$ & 10.1 & $5,415.0$ \\
\hline 393750104415901 & MC-2B & 39.63056 & -104.69972 & 5,800 & 12.0 & $7.0-12.0$ & $7 / 17 / 2007$ & 4.9 & $5,795.1$ \\
\hline 394456104503501 & $\mathrm{SC}-4$ & 39.74889 & -104.84306 & 5,365 & 48.0 & $43.0-48.0$ & $7 / 31 / 2007$ & 44.3 & $5,320.7$ \\
\hline 394434104453601 & SC-6 & 39.74278 & -104.76000 & 5,455 & 35.0 & $20.0-35.0$ & $7 / 18 / 2007$ & 4.72 & $5,450.3$ \\
\hline 394525104495401 & SCTC-5 & 39.75694 & -104.83167 & 5,330 & 35.0 & $25.0-35.0$ & $7 / 18 / 2007$ & 6.14 & $5,323.9$ \\
\hline 394520104500001 & TC-1 & 39.75556 & -104.83333 & 5,321 & 24.0 & $14.0-24.0$ & $7 / 20 / 2007$ & 5.77 & $5,315.2$ \\
\hline 394522104495801 & TC-2 & 39.75611 & -104.83278 & 5,333 & 27.0 & $17.0-27.0$ & $7 / 20 / 2007$ & 6.34 & $5,326.7$ \\
\hline 393846104465601 & URLUS-18 & 39.64631 & -104.78228 & 5,725 & 38.2 & $28.4-38.2$ & $7 / 17 / 2007$ & 20.1 & $5,704.9$ \\
\hline 393742104453801 & URLUS-28 & 39.62839 & -104.76064 & 5,782 & 28.6 & $18.3-28.1$ & $7 / 12 / 2007$ & 10.5 & $5,771.5$ \\
\hline 393903104455701 & URLUS-30 & 39.65100 & -104.76600 & 5,725 & 38.5 & $28.0-37.5$ & $8 / 06 / 2007$ & 15.0 & $5,710.0$ \\
\hline 394304104483801 & WT-1 & 39.71778 & -104.81056 & 5,409 & 15.0 & $10.0-15.0$ & $7 / 16 / 2007$ & 4.0 & $5,405.0$ \\
\hline 393903104480701 & WT-11 & 39.65083 & -104.80194 & 5,660 & 17.0 & $7.0-17.0$ & $7 / 19 / 2007$ & 8.2 & $5,651.8$ \\
\hline 394002104483001 & WT-12 & 39.66722 & -104.80833 & 5,624 & 40.0 & $25.0-40.0$ & $7 / 19 / 2007$ & 15.1 & $5,609.0$ \\
\hline 394040104465701 & WT-14 & 39.67778 & -104.78250 & 5,589 & 13.0 & $8.0-13.0$ & $7 / 31 / 2007$ & 5.1 & $5,583.9$ \\
\hline 394007104465001 & WT-19 & 39.66861 & -104.78056 & 5,525 & 26.0 & $16.0-26.0$ & $7 / 24 / 2007$ & 7.6 & $5,517.4$ \\
\hline 394304104483301 & WT-2 & 39.71778 & -104.80917 & 5,421 & 20.0 & $10.0-20.0$ & $7 / 30 / 2007$ & 11.4 & $5,409.6$ \\
\hline 394055104480001 & WT-4 & 39.68194 & -104.80000 & 5,510 & 32.0 & $22.0-32.0$ & $7 / 23 / 2007$ & 4.7 & $5,505.3$ \\
\hline 393939104453701 & WT-8 & 39.66083 & -104.76028 & 5,613 & 26.0 & $8.5-18.5$ & $7 / 23 / 2007$ & 4.5 & $5,608.5$ \\
\hline
\end{tabular}


(Garbarino and others, 2006); for calcium, iron, magnesium, potassium, silica, and sodium by ICP-AES (Fishman, 1993; Standard Method 3120); for chloride and sulfate by ion chromatography (Fishman and Friedman, 1989); and for nitrite plus nitrate by colorimetry (Fishman, 1993). Results were multiplied by percent saturation (in decimals) to correct back to dry weight of soil and allow direct comparison between samples.

\section{Quality Assurance and Quality Control}

Quality assurance and quality control (QA/QC) for water samples was accomplished using standard USGS protocols and equipment for (1) field collection of surface-water and groundwater samples; (2) equipment cleaning between collection of individual samples; (3) sample analysis at USGS laboratories; and (4) collection and analysis of blanks, replicates, and standard-reference samples. Field and laboratory methods for surface-water sample collection and analysis are discussed in the "Surface-Water Sample Processing and Analytical Methods" section of this report. Field and laboratory methods for groundwater sample collection and analysis are discussed in the "Groundwater Sample Collection, Processing, and Analytical Methods" section of this report. Analytical data for QA/QC water samples collected July-August 2007 are provided and described in Appendix 2.

Precision and accuracy of sampling and analysis procedures were evaluated through analysis of blanks, replicates, and standard-reference materials. Analysis of blank samples indicated that concentrations of most analytes, including selenium, were unaffected by contamination during sample processing. Aluminum contamination was significant relative to concentrations in environmental samples. Minor zinc contamination was likely present in environmental samples having concentrations less than $2 \mu \mathrm{g} / \mathrm{L}$. In general these contamination issues are minor and do not affect the interpretations presented herein. Analysis of replicate samples indicated that most analytes, including selenium, showed excellent precision (less than 10 relative percent difference). Minor problems noted for aluminum, iron, zinc and orthophosphate are described in Appendix 2 , but do not affect interpretations presented herein. Analysis of standard-reference materials spiked with elevated concentrations of bromide and sulfate indicated excellent results for iron, sodium, selenium, and uranium compared to the most probable values. Results indicated potential low bias in silica and zinc results when sulfate concentrations were greater than 1,000 $\mathrm{mg} / \mathrm{L}$. Low bias occurred for low concentrations of manganese. These minimal issues do not affect the results presented herein, but are included in the interest of full disclosure, and for anyone who may use the data for purposes other than this study. Negative bias in the concentrations of unfiltered relative to filtered selenium was likely caused by differences in the analytical techniques and instrumentation used for the analyses (Appendix 2). Analytical results for filtered selenium samples were used for all calculations and interpretations presented herein because they did not show appreciable bias. Bias in the total recoverable selenium concentrations is attributed to laboratory methods, and because the analytical issues could not be completely resolved, the unfiltered selenium analyses were excluded from the dataset used for this study.

\section{Streamflow Conditions}

Streamflow conditions observed and measured during the synoptic water-quality study represent summer low-flow (base flow) and summer rainfall conditions for July 2007. Streamflow, as determined from current-meter measurements and the tracer-dilution method, is described with respect to stage and its relation to changing constituent concentrations. Results provide the hydrologic setting for the concentration and load interpretations presented in the "Selenium Concentrations" and "Surface-Water Selenium Loads" sections of this report.

\section{Low-Flow Conditions and Rainfall}

Hydrologic conditions in the Toll Gate Creek watershed are represented herein by data from USGS stream-gaging station 394329104490101 (referred to herein as the "6th Avenue stream gage") and an associated rain gage located just upstream, near the end of the TGM subreach (fig. 4). Stage data from the 6th Avenue stream gage are presented in figure 13. The surfacewater field effort described in this report was completed during a low-flow period of the annual hydrograph (fig. 13). This low-flow period was selected to facilitate implementation of the tracer-dilution method and to quantify the constituent sources attributable to groundwater discharge (Kimball and others, 2007). A relatively dry period preceded the primary synoptic sampling period, as only one rainfall event was recorded at the 6th Avenue stream gage from June 19, 2007 through July 26, 2007. This dry period was followed by a series of rainfall events from July 27 through August 1, 2007 that increased stream stage and therefore streamflow (fig. 14). Synoptic sampling activities (table 1) were generally conducted 1-2 days following each rainfall event, after peak streamflow was observed at the 6th Avenue stream gage. As a result, synoptic sampling within each subreach was conducted as streamflow was receding (fig. 15).

\section{Effects of Increased Streamflow on Constituent Concentrations}

Constituent concentrations may increase or decrease in response to rainfall with the magnitude and direction of the change often being dependent on the timing of sample collection. Constituent concentrations may increase during the initial rise of the hydrograph, for example, as sources of a constituent are flushed from the landscape. This increase in concentration typically is short lived, however, as the sources are rapidly depleted, streamflow increases, and the effects of dilution begin to predominate stream-water chemistry. This dilution effect was observed in the data from the 6th Avenue stream gage in the TGM subreach, where specific-conductance 


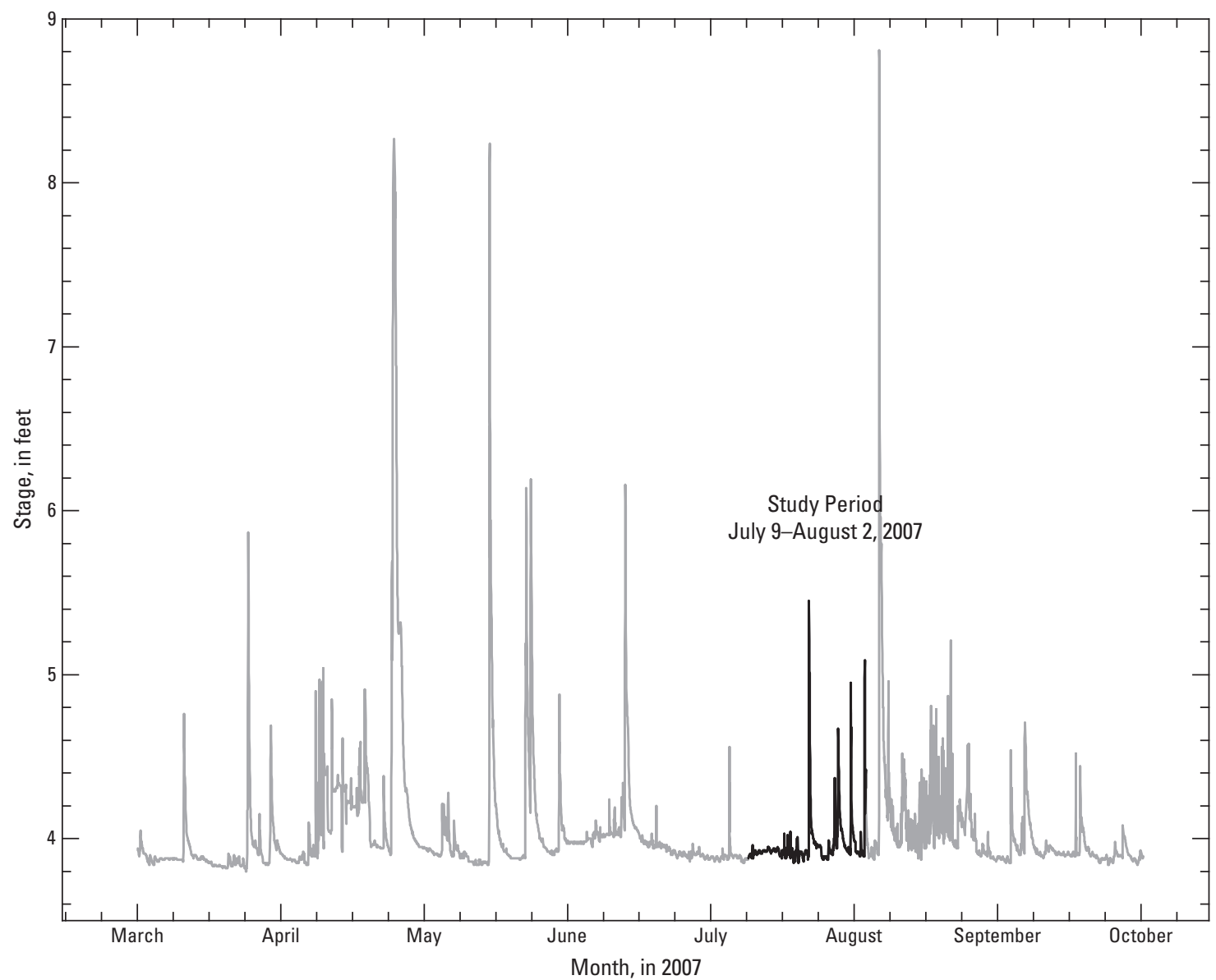

Figure 13. Graph showing Toll Gate Creek stream stage at the 6th Avenue stream gage (U.S. Geological Survey stream-gaging station 394329104490101), March-September 2007. 


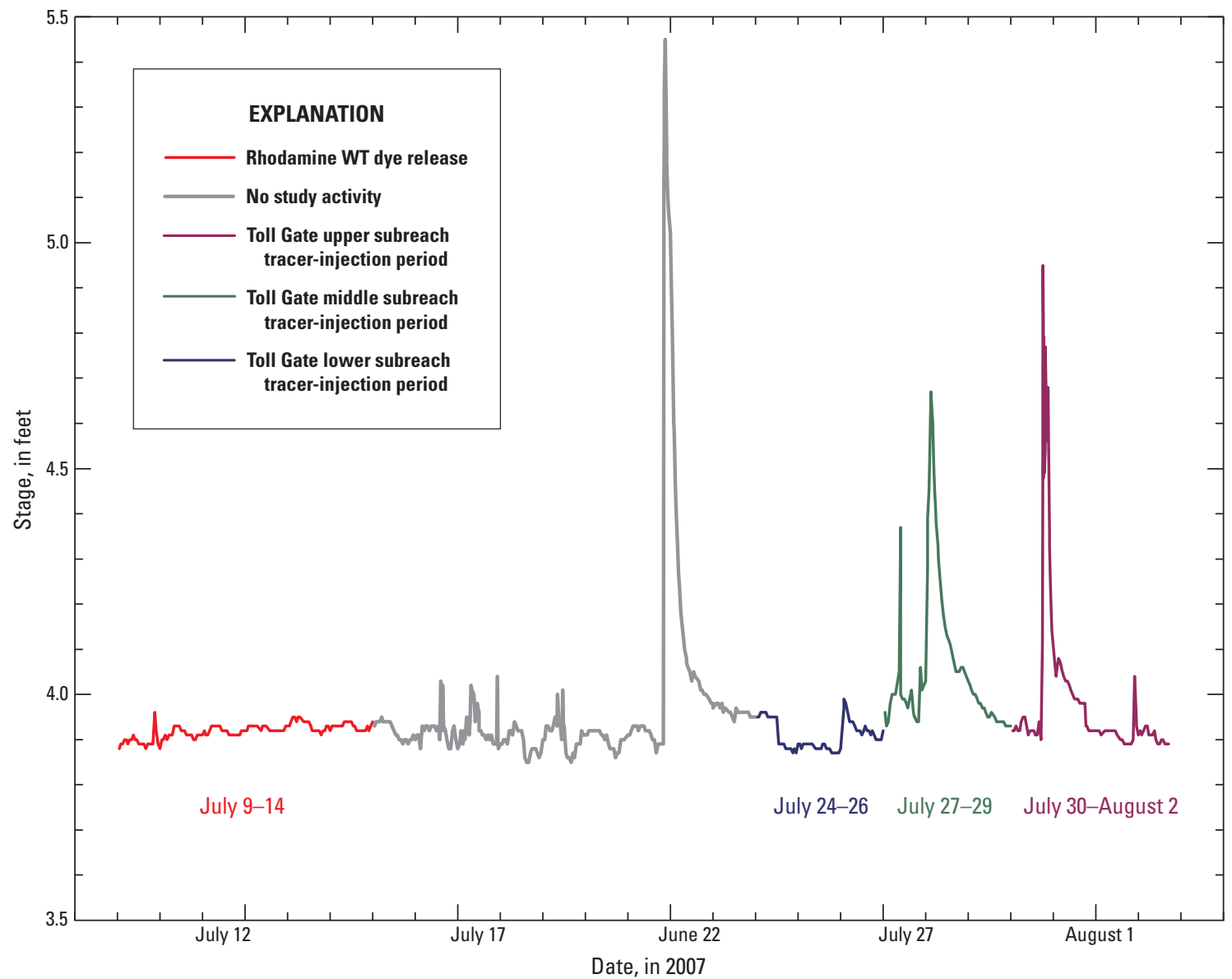

Figure 14. Graph showing Toll Gate Creek stream stage at the 6th Avenue stream gage (U.S. Geological Survey stream-gaging station 394329104490101) showing sequence of stream field activities and periods of tracer injection, July-August 2007. 


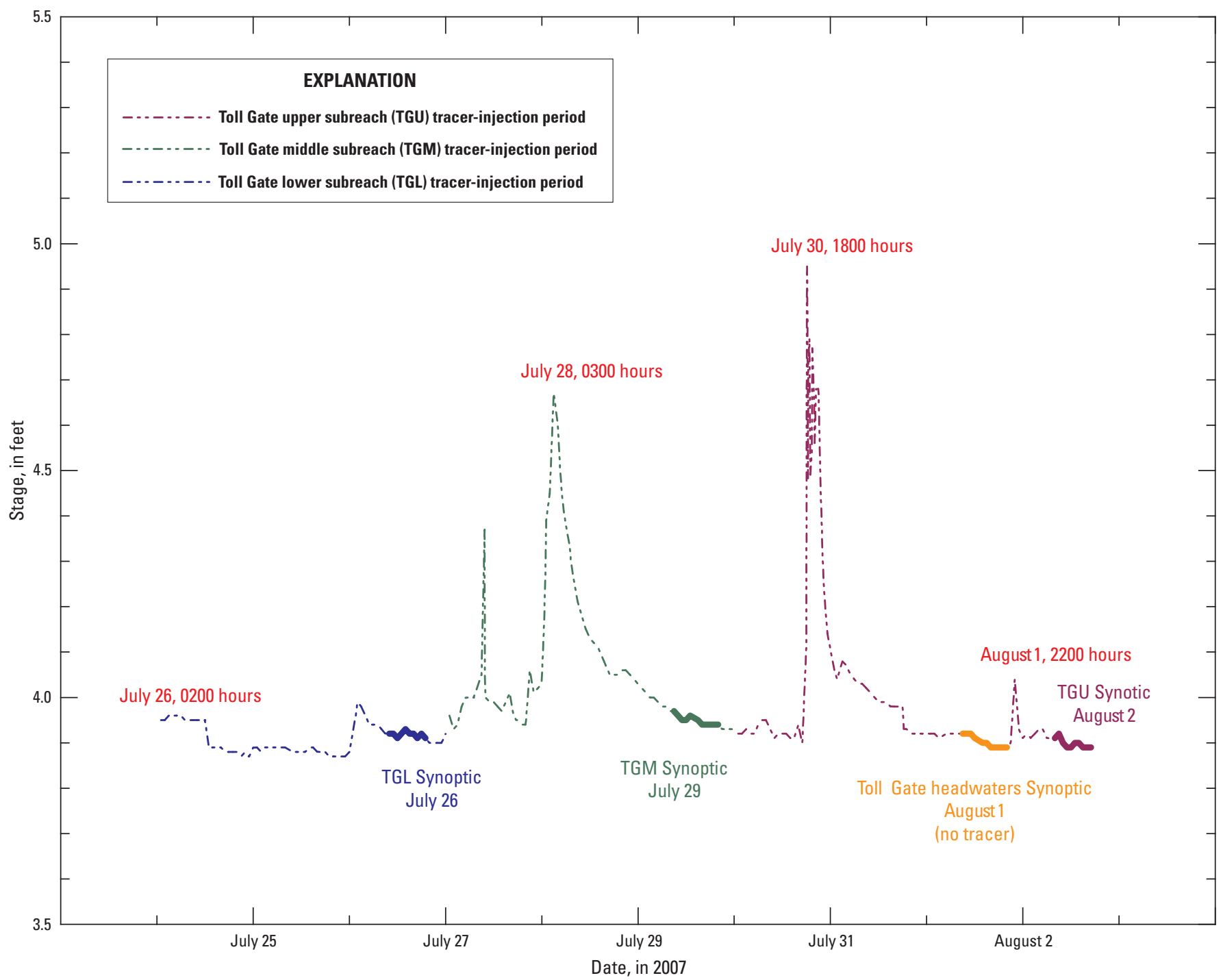

Figure 15. Graph showing Toll Gate Creek stream stage at the 6th Avenue stream gage (U.S. Geological Survey stream-gaging station 394329104490101) during tracer-injection and synoptic-sampling periods. Stream stage during synoptic-sampling periods is shown as a thick line and indicates synoptic sampling occurred during surface-water flow recession. 
measurements are available from both a dry period (during the rhodamine WT dye release July 9-14, 2007) and a wet period (a large rainfall event occurred on the day prior to the TGM synoptic sampling; Appendix 1). Specific-conductance measurements made during the dry period were greater than 2,500 microsiemens per centimeter at $25^{\circ} \mathrm{C}(\mu \mathrm{S} / \mathrm{cm})$, whereas specific-conductance measurements on the day of the rain event (July 28) were less than $1,100 \mu \mathrm{S} / \mathrm{cm}$ (table 5). The effects of dilution subsided on the synoptic-sampling day (July 29) as the hydrograph receded and specific conductance began to return to pre-rainfall levels (fig. 16).

\section{Final Streamflow Estimates}

Final streamflow estimates for each study subreach (Appendix 1) are shown in figure 17. The effects of rainfall are most pronounced for the TGM subreach, where a large rainfall event following the TGL synoptic sampling resulted in increased streamflow (see streamflow estimates for overlapping TGM/TGL stream sites, fig. 17). Streamflow decreased following the TGM synoptic, as shown by the lower streamflow estimates at the end of TGU subreach (see overlap of TGU/TGM, fig. 17).

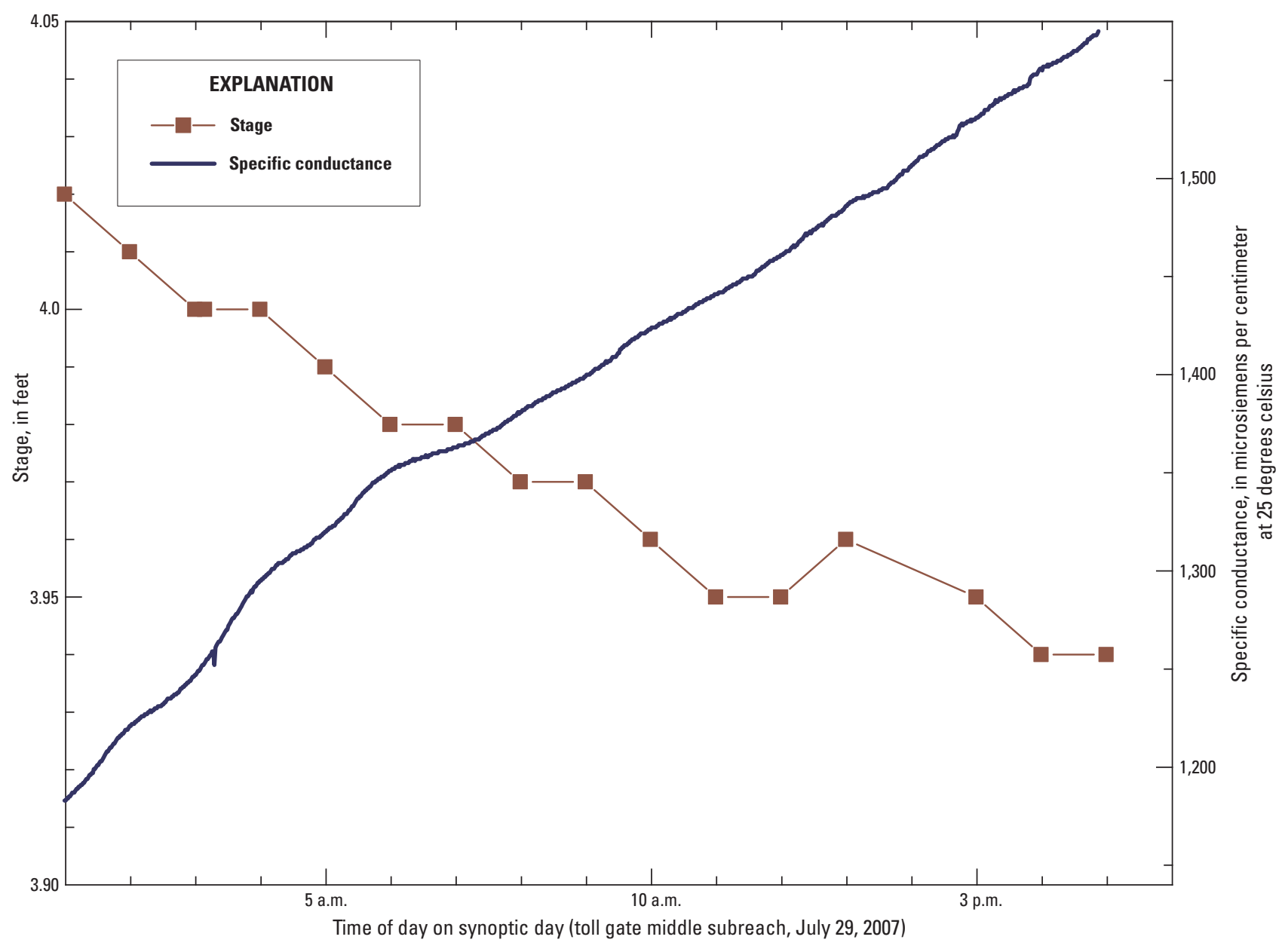

Figure 16. Graph showing relation between stream stage and specific conductance at the 6th Avenue stream gage (U.S. Geological Survey stream-gaging station 394329104490101) during Toll Gate Creek middle subreach synoptic sampling, July 29, 2007. 
As discussed in Appendix 1, development of a final streamflow profile for Toll Gate Creek is a subjective exercise that is prone to uncertainty; therefore, final streamflow estimates for specific stream sites need to be viewed in light of the potential errors. As such, specific conclusions based on individual estimates of streamflow and point-to-point comparisons (increases/decreases for one stream site to the next) are not appropriate. Despite this limitation, the general characteristics of the final streamflow profile support several conclusions regarding Toll Gate Creek stream hydrology. Streamflow estimated for the TGH, TGU, and TGL subreaches is representative of low-flow (base flow) conditions, and the estimated streamflow ranged from about 2 cubic feet per second $\left(\mathrm{ft}^{3} / \mathrm{s}\right)$ near Buckley Road to about $4 \mathrm{ft}^{3} / \mathrm{s}$ downstream from 6th Avenue (fig. 17). Farther downstream from 6th Avenue, estimated streamflow increased to as much as $7.5 \mathrm{ft}^{3} / \mathrm{s}$ upstream from the confluence with Sand Creek. Streamflow thus increases steadily within each subreach and for the entire study reach, indicating that Toll Gate Creek is a gaining stream. The lack of large tributary inflows and the spatial distribution of small tributary inflows, seeps, and springs indicates that diffuse and discrete groundwater inflow supports streamflow during low-flow conditions along the entire 18-km stream reach. Streamflow within the TGM subreach was substantially greater than that in the TGH, TGU, and TGL subreaches during the study period because of local precipitation (rain). Streamflow in the TGM subreach increased rapidly in response to the local rainfall as would be expected in an suburban setting where paved areas and channelization increase surface-water runoff and decrease runoff transit time to local drainages compared to undeveloped areas.

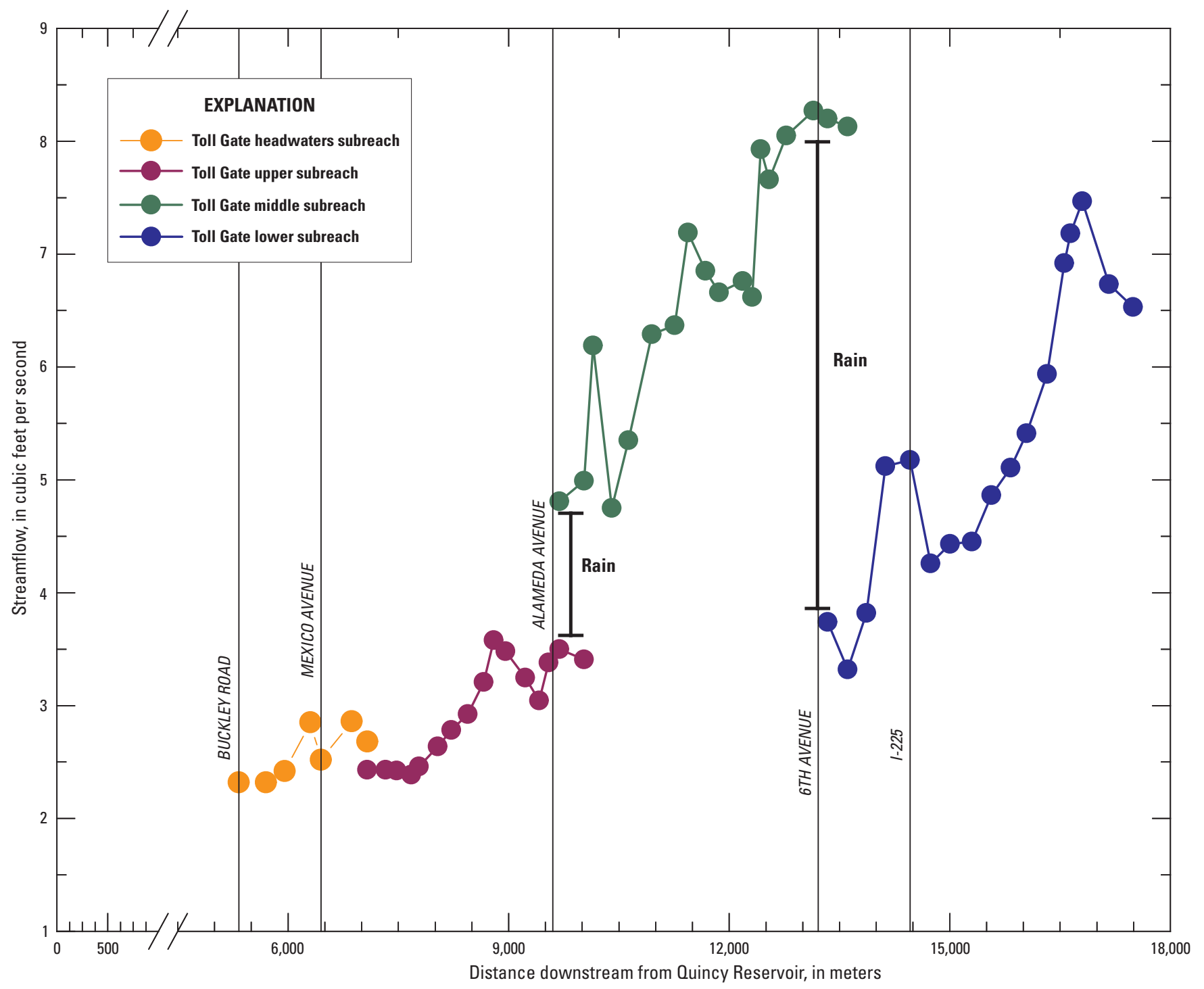

Figure 17. Graph showing final streamflow estimates related to distance downstream from Quincy Reservoir, Toll Gate Creek, JulyAugust 2007. 


\section{Water-Quality Conditions}

Surface-water and groundwater quality in Toll Gate Creek are affected by surface-water runoff, precipitation and irrigation recharge to the water table, water-rock interaction with surficial and bedrock materials, evaporation, and urban land and water use. Selenium was the primary constituent of interest for this study; however, samples also were analyzed for a suite of major ions, trace elements, nutrients, isotopes, and environmental tracers such that overall water quality and the processes affecting that quality can be described. Correlations among constituent concentrations indicate that selenium and major ions in surface water and groundwater are derived from the same geologic sources in the watershed, and relations among various constituents indicate that hydrological, water-rock interaction (dissolution and precipitation), redox, evaporative, and likely biological processes affect selenium concentrations in Toll Gate Creek.

\section{Data Availability}

Selected analytical results for surface-water samples are provided in table 5 , and selected analytical results for groundwater samples are provided in table 6. Complete analytical results for samples discussed in this report can be accessed from the USGS National Water Information System (NWIS) (http://waterdata.usgs.gov/nwis/, accessed August 28, 2008) by searching for data using the USGS site identification numbers listed in tables 2 and 4. For surface-water stream samples collected during tracer-injection plateau periods, the reported sodium and bromide concentrations are affected by injection of the sodium-bromide tracer and are not considered representative of environmental concentrations.

\section{Selenium Concentrations}

Concentrations of dissolved selenium in all sampled subreaches of Toll Gate Creek exceeded the Colorado aquatic-life standard of $4.6 \mu \mathrm{g} / \mathrm{L}$ during July and August 2007 (fig. 18), consistent with previous findings (for example, Herring and Walton-Day, 2007). Concentrations in the upper part of the TGH subreach, where West Toll Gate Creek flows through a wetland area and then the concrete-lined channel, were close to the aquatic-life standard at about $5 \mu \mathrm{g} / \mathrm{L}$. The wetlands upstream from Hampden Avenue contain abundant organic matter, which promotes low-oxygen and reducing conditions that are likely attenuating stream selenium concentrations. Reduced and insoluble forms of selenium can be removed from the water column by precipitation of selenium-bearing sulfide minerals or adsorption onto and (or) complexation with the abundant organic matter and plant material in the wetland reach. Downstream from the wetland reach, stream selenium concentrations in the concrete-lined channel were near $5 \mu \mathrm{g} / \mathrm{L}$ with a large and abrupt increase of $15 \mu \mathrm{g} / \mathrm{L}$ observed at the downstream end of the concrete-lined channel. The concrete-lined channel is likely preventing groundwater and thus selenium discharge to the stream as evidenced by the lack of inflow through the reach. Stream concentrations downstream from Buckley Road and the concrete-lined channel in subreaches TGH, TGU, and TGL (reaches not substantially affected by rainfall during sampling) generally were greater than $10 \mu \mathrm{g} / \mathrm{L}$ and less than $20 \mu \mathrm{g} / \mathrm{L}$ (fig. 18). The maximum stream selenium concentration of $19 \mu \mathrm{g} / \mathrm{L}$ occurred at Buckley Road at the downstream end of the concrete-lined channel and downstream from a right-bank culvert inflow with a selenium concentration of $78.5 \mu \mathrm{g} / \mathrm{L}$ (TG-WP451RLR; fig. 19). Concentratins of dissolved selenium less than $10 \mu \mathrm{g} / \mathrm{L}$ for the TGM subreach are attributed to dilution (see "Effects of Increases of Streamflow on Constituent Concentrations") that occurred because of rainfall and the resulting increased streamflow (fig. 18).

Downstream from the concrete-lined channel, increases in stream selenium concentrations were observed downstream from inflows with selenium concentrations greater than that of the stream. Concentrations of dissolved selenium in 11 of the 32 sampled inflows exceeded $21 \mu \mathrm{g} / \mathrm{L}$ (circled on fig. 19), whereas the dissolved selenium concentrations in the remaining 21 inflows were less than $12 \mu \mathrm{g} / \mathrm{L}$ (fig. 19). All of the inflows exceeding $21 \mu \mathrm{g} / \mathrm{L}$ had concentrations greater than nearby stream concentrations (fig. 19, table 7) and, thus, have the potential to increase stream concentrations. For example, the right-bank inflow TG-WP451RLR, located 4,707 m downstream from Quincy Reservoir, had a dissolved selenium concentration of nearly $80 \mu \mathrm{g} / \mathrm{L}$ (table 7), and is likely responsible for the aforementioned increase in stream selenium concentration downstream from Buckley Road (fig. 19).

The 11 inflows with concentrations of dissolved selenium exceeding $21 \mu \mathrm{g} / \mathrm{L}$ represent surface-water runoff and groundwater discharge to the stream from the surrounding watershed. Nine of the 11 inflows emanate from culverts, which are channelized tributaries and storm drains that collect surface-water runoff and groundwater discharge. During base-flow conditions, water from the culverts represents groundwater discharge to Toll Gate Creek. Two of the 11 inflows are springs along the contact between surficial materials and underlying bedrock where groundwater discharges directly to the stream (figs. 20 and 21). Reconnaissance of the drainage basin indicates that discrete anthropogenic sources such as industrial or wastewater discharge of selenium are not present.

Despite the presence of inflows with selenium concentrations greater than that of the stream, stream selenium concentrations were less than $20 \mu \mathrm{g} / \mathrm{L}$ all along Toll Gate Creek (fig. 19) indicating that selenium was being removed from the water column by chemical or biological reactions and was not transported conservatively through the surface-water system during summer low-flow conditions. Several reactions could account for decreases in stream selenium concentrations. Where oxidized conditions are present in rapidly flowing reaches, oxidized and soluble forms of selenium (selenite and selenate) may adsorb to iron oxides or clays that are present in the streambed sediment and substrate. Oxidized selenium 


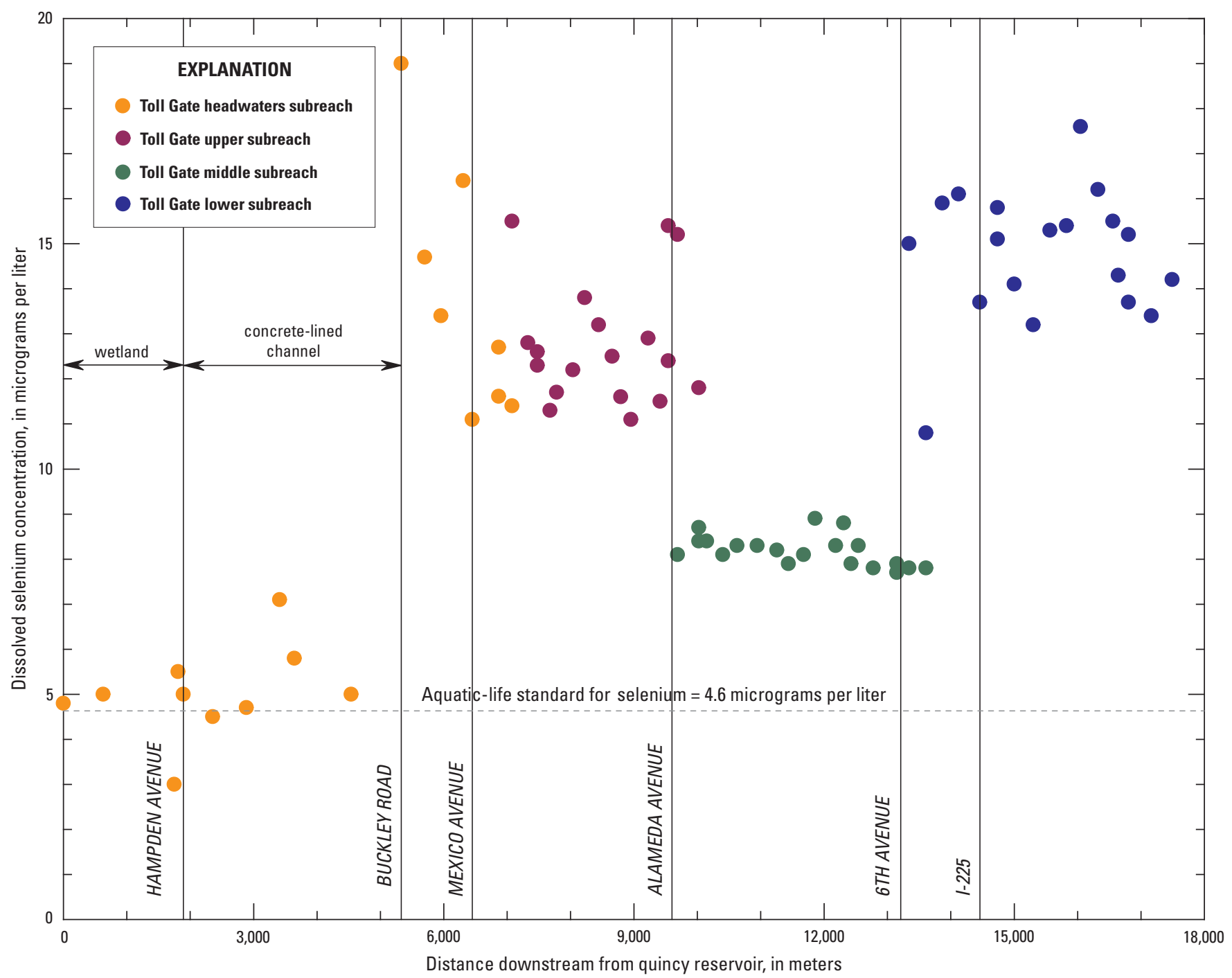

Figure 18. Graph showing dissolved stream selenium concentrations related to distance downstream from Quincy Reservoir, Toll Gate Creek, July-August 2007. 


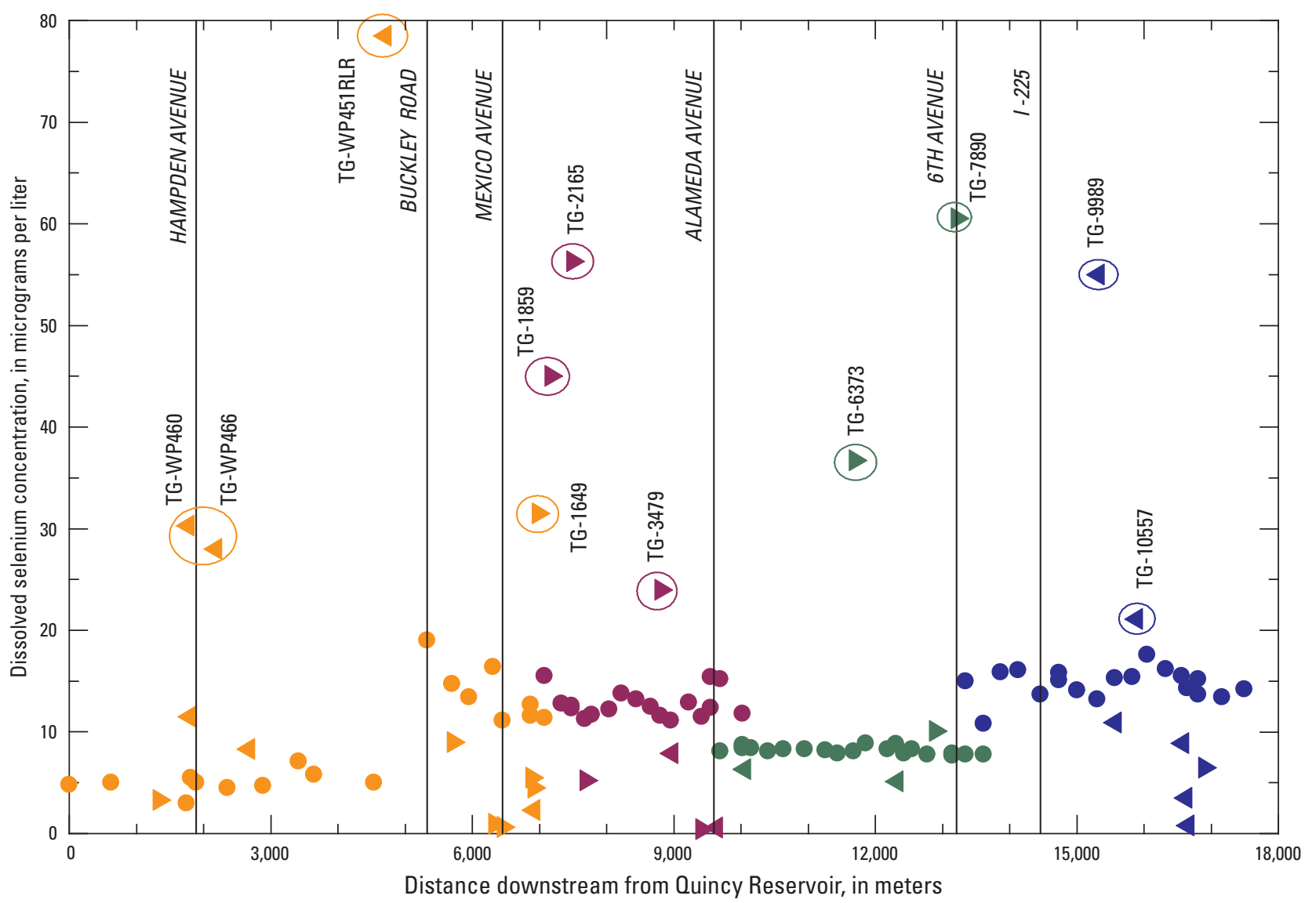

\begin{tabular}{|l|l|}
\hline & EXPLANATION \\
Toll Gate headwaters subreach: & stream; $>$ left-bank inflow; $<$ right-bank inflow \\
Toll Gate upper subreach: & stream; $>$ left-bank inflow; $<$ right-bank inflow \\
Toll Gate middle subreach: & stream; $>$ left-bank inflow; $<$ right-bank inflow \\
Toll Gate lower subreach: & stream; $>$ left-bank inflow; $<$ right-bank inflow \\
TG-WP460 & 11 inflows having selenium concentration \\
& greater than 21 micrograms per liter
\end{tabular}

Figure 19. Graph showing dissolved stream and inflow selenium concentrations related to distance downstream from Quincy Reservoir, Toll Gate Creek, July-August 2007. 
Table 5. Selected analytical results for synoptic surface-water samples, Toll Gate Creek, July-August 2007.

[All analyses completed on filtered samples except Field pH, Field SC, Temp, $\delta^{2} \mathrm{H}$, and $\delta^{18} \mathrm{O}$; Site ID, U.S. Geological Survey site identification number; LBI, left-bank inflow; RBI, right-bank inflow; SC, specific conductance in microSiemens per centimeter at 25 degrees Celsius; TDS, total dissolved solids, in $\mathrm{mg} / \mathrm{L}$; Temp, temperature; ${ }^{\circ} \mathrm{C}$, degrees Celsius; Ca, calcium; $\mathrm{mg} / \mathrm{L}$, milligrams per liter; $\mathrm{Mg}$, magnesium; $\mathrm{Na}$, sodium; Se, selenium; $\mu \mathrm{g} / \mathrm{l}$, micrograms per liter; $\mathrm{U}$, uranium; $\mathrm{SO}_{4}$, sulfate; $\mathrm{HCO}_{3}$, bicarbonate; $\mathrm{Cl}$, chloride; $\mathrm{Br}$, bromide; $\mathrm{NO}_{2}+\mathrm{NO}_{3}$, nitrite plus nitrate; $\mathrm{N}$, nitrogen; $\delta^{2} \mathrm{H}$, stable isotope ratio of hydrogen $\left({ }^{2} \mathrm{H}\right.$ and $\left.{ }^{1} \mathrm{H}\right)$ relative to Vienna Standard Mean Ocean Water; $\delta^{18} \mathrm{O}$, stable isotope ratio of oxygen $\left({ }^{18} \mathrm{O}\right.$ and $\left.{ }^{16} \mathrm{O}\right)$ relative to Vienna Standard Mean Ocean Water; blank, no data]

\begin{tabular}{|c|c|c|c|c|c|c|c|c|c|c|c|c|c|c|c|c|c|c|}
\hline Site ID & Source & $\begin{array}{c}\text { Sample } \\
\text { Date }\end{array}$ & $\begin{array}{c}\text { Field } \\
\mathrm{pH}\end{array}$ & $\begin{array}{l}\text { Field } \\
\text { SC }\end{array}$ & $\begin{array}{c}\text { TDS } \\
\text { (mg/L) }\end{array}$ & $\begin{array}{l}\text { Temp } \\
\left({ }^{\circ} \mathrm{C}\right)\end{array}$ & $\begin{array}{c}\mathrm{Ca} \\
\text { (mg/L) }\end{array}$ & $\underset{(\mathrm{mg} / \mathrm{L})}{\mathrm{Mg}}$ & $\begin{array}{c}\mathrm{Na} \\
(\mathrm{mg} / \mathrm{L})\end{array}$ & $\begin{array}{c}\text { Se } \\
(\mu \mathrm{g} / \mathrm{L})\end{array}$ & $\underset{(\mu \mathrm{g} / \mathrm{L})}{U}$ & $\begin{array}{c}\mathrm{SO}_{4} \\
\text { (mg/L) }\end{array}$ & $\begin{array}{c}\mathrm{HCO}_{3} \\
\text { (mg/L) }\end{array}$ & $\begin{array}{c}\mathrm{Cl} \\
\text { (mg/L) }\end{array}$ & $\begin{array}{c}\mathrm{Br} \\
(\mathrm{mg} / \mathrm{L})\end{array}$ & $\begin{array}{c}\mathrm{NO}_{2}+\mathrm{NO}_{3} \\
\text { as } \mathrm{N} \\
(\mathrm{mg} / \mathrm{L})\end{array}$ & $\begin{array}{c}\delta^{2} \mathbf{H} \\
\text { (per mil) }\end{array}$ & $\begin{array}{c}\delta^{18} \mathbf{0} \\
\text { (per mil) }\end{array}$ \\
\hline 393821104465601 & Stream & $8 / 01 / 2007$ & 8.1 & 1,760 & 1,330 & 27.9 & 190 & 38.2 & 158 & 4.8 & 27.5 & 607 & 226 & 91.1 & 0.74 & 0.04 & -83.7 & -10.15 \\
\hline 393836104470301 & Stream & $8 / 01 / 2007$ & 7.9 & 1,740 & 1,340 & 26.8 & 197 & 38.5 & 158 & 5.0 & 28.5 & 612 & 227 & 94.6 & 0.71 & & & \\
\hline 393858104465701 & LBI & $8 / 01 / 2007$ & 7.9 & 1,750 & 1,310 & 27.6 & 195 & 37.8 & 156 & 3.3 & 23.4 & 563 & 257 & 97.8 & 0.69 & & & \\
\hline 393908104464501 & Stream & $8 / 01 / 2007$ & 7.8 & 1,870 & 1,410 & 22.6 & 204 & 39.3 & 168 & 3.0 & 21.1 & 604 & 272 & 113 & 0.78 & 0.11 & -85.8 & -10.77 \\
\hline 393909104464502 & RBI & $8 / 01 / 2007$ & 9.0 & 2,700 & 2,310 & 30.5 & 258 & 67.8 & 310 & 30.3 & 15.7 & 1,240 & 81 & 182 & 1.48 & 0.21 & -89.1 & -10.3 \\
\hline 393910104464501 & RBI & $8 / 01 / 2007$ & 7.9 & 3,470 & 3,020 & 18.4 & 376 & 84.9 & 430 & 11.5 & 37.5 & 1,570 & 307 & 162 & 1.32 & & & \\
\hline 393910104464502 & Stream & $8 / 01 / 2007$ & 7.9 & 1,940 & 1,510 & 23.5 & 207 & 42.4 & 181 & 5.5 & 21.1 & 657 & 255 & 119 & 0.82 & 0.11 & -86.3 & -10.76 \\
\hline 393913104464401 & Stream & $8 / 01 / 2007$ & 8.1 & 1,970 & 1,490 & 24.2 & 214 & 43.5 & 179 & 5.0 & 18.8 & 671 & 251 & 120 & 0.81 & & & \\
\hline 393921104463901 & RBI & $8 / 01 / 2007$ & 8.2 & 1,480 & 1,040 & 19.2 & 149 & 30.8 & 137 & 28.0 & 10.8 & 397 & 186 & 133 & 0.69 & & & \\
\hline 393927104463901 & Stream & $8 / 01 / 2007$ & 8.5 & 1,800 & 1,360 & 30.0 & 157 & 41.7 & 176 & 4.5 & 17.9 & 655 & 131 & 120 & 0.81 & 0.06 & -84.1 & -10.4 \\
\hline 393937104463901 & RBI & $8 / 01 / 2007$ & 9.0 & 1,710 & 1,260 & 31.3 & 138 & 36.3 & 172 & 8.3 & 13.5 & 621 & 80 & 125 & 0.76 & & & \\
\hline 393944104464001 & Stream & $8 / 01 / 2007$ & 8.7 & 1,770 & 1,320 & 32.4 & 154 & 39.9 & 178 & 4.7 & 16.5 & 654 & 100 & 122 & 0.79 & & & \\
\hline 394000104464201 & Stream & $8 / 01 / 2007$ & 9.0 & 1,800 & 1,290 & 31.9 & 148 & 35.6 & 178 & 7.1 & 13.9 & 650 & 75 & 123 & 0.84 & 0.06 & -80.3 & -9.44 \\
\hline 394006104464501 & Stream & $8 / 01 / 2007$ & 7.9 & 2,030 & 1,550 & 26.3 & 216 & 43.6 & 198 & 5.8 & 17.1 & 720 & 221 & 120 & 0.91 & 0.08 & -83.7 & -10.27 \\
\hline 394021104470701 & Stream & $8 / 01 / 2007$ & 8.7 & 1,910 & 1,450 & 30.0 & 173 & 41.5 & 192 & 5.0 & 16.7 & 725 & 112 & 121 & 0.87 & & & \\
\hline 394025104471001 & RBI & $8 / 01 / 2007$ & 8.1 & 2,970 & 2,510 & 22.0 & 288 & 65.2 & 376 & 78.5 & 54.2 & 1,280 & 274 & 154 & 1.20 & & & \\
\hline 394037104472901 & Stream & $8 / 01 / 2007$ & 8.2 & 2,200 & 1,660 & 30.0 & 197 & 44.3 & 218 & 19.0 & 20.0 & 843 & 127 & 132 & 1.02 & 0.84 & -83.6 & -10.25 \\
\hline 394039104474201 & Stream & $8 / 01 / 2007$ & 8.0 & 2,210 & 1,710 & & 224 & 43.2 & 205 & 14.7 & 22.1 & 803 & 228 & 125 & 0.92 & & & \\
\hline 394039104474301 & LBI & $8 / 01 / 2007$ & 7.3 & 1,380 & 989 & & 135 & 23.7 & 144 & 9.0 & 15.0 & 378 & 221 & 104 & 0.51 & & & \\
\hline 394046104474701 & Stream & $8 / 01 / 2007$ & 7.9 & 2,120 & 1,600 & & 216 & 40.9 & 202 & 13.4 & 21.9 & 764 & 237 & 125 & 0.85 & & & \\
\hline 394051104475901 & Stream & $8 / 01 / 2007$ & 7.8 & 2,080 & 1,610 & 20.5 & 231 & 43.4 & 203 & 16.4 & 21.9 & 737 & 243 & 123 & 0.89 & 0.89 & -84.2 & -10.37 \\
\hline 394052104480001 & LBI & $8 / 01 / 2007$ & 7.3 & 1,070 & 650 & & 53.5 & 10.1 & 160 & 0.9 & 1.6 & 41.4 & 147 & 250 & 0.12 & 0.07 & -69.0 & -8.39 \\
\hline 394055104480301 & Stream & $8 / 01 / 2007$ & 7.7 & 2,060 & 1,530 & 20.5 & 214 & 41.5 & 212 & 11.1 & 21.3 & 686 & 241 & 138 & 0.82 & & & \\
\hline 394055104480302 & LBI & $8 / 01 / 2007$ & 7.4 & 1,400 & 762 & 18.5 & 68.7 & 14.3 & 180 & 0.7 & 3.6 & 52.4 & 206 & 277 & 0.21 & 0.16 & -73.8 & -9.11 \\
\hline 394107104481001 & Stream & $8 / 01 / 2007$ & 7.8 & 2,020 & 1,500 & 22.5 & 184 & 39.6 & 198 & 11.6 & 20.0 & 684 & 194 & 132 & 0.82 & 0.57 & -82.0 & -9.96 \\
\hline 394107104481101 & LBI & $8 / 01 / 2007$ & 8.1 & 1,330 & 911 & 21.0 & 109 & 25.1 & 133 & 5.5 & 15.4 & 317 & 241 & 89.1 & 0.49 & & & \\
\hline 394107104481102 & LBI & $8 / 01 / 2007$ & 7.4 & 2,110 & 1,590 & 19.0 & 211 & 41.2 & 225 & 4.5 & 18.3 & 694 & 226 & 164 & 0.87 & & & \\
\hline 394107104481103 & RBI & $8 / 01 / 2007$ & 7.5 & 2,290 & 1,680 & 17.0 & 222 & 40.1 & 223 & 2.3 & 27.2 & 648 & 282 & 230 & 0.86 & & & \\
\hline 394109104481201 & LBI & $8 / 01 / 2007$ & 7.5 & 2,910 & 2,270 & 17.5 & 270 & 51.5 & 406 & 31.5 & 43.6 & 988 & 393 & 200 & 0.93 & & & \\
\hline 394112104481401 & Stream & $8 / 01 / 2007$ & 7.9 & 1,990 & 1,430 & 22.0 & 182 & 38.3 & 200 & 11.4 & 16.9 & 662 & 177 & 130 & 0.85 & 0.51 & -81.4 & -9.88 \\
\hline 394112104481401 & Stream & $8 / 02 / 2007$ & 8.1 & 2,170 & 1,690 & 23.0 & 223 & 49.2 & 245 & 15.5 & 20.7 & 758 & 216 & 150 & 0.96 & 0.73 & -84.3 & -10.16 \\
\hline 394115104481501 & LBI & $8 / 02 / 2007$ & 7 & 4,090 & 3,410 & 12.0 & 395 & 78.3 & 544 & 45.0 & 66.4 & 1690 & 308 & 245 & 1.64 & 5.18 & -99.7 & -12.89 \\
\hline 394119104481801 & Stream & $8 / 01 / 2007$ & 8.1 & 2,090 & 1,630 & 24.0 & 182 & 40.5 & 216 & 12.8 & 20.8 & 725 & 192 & 151 & 3.00 & & & \\
\hline 394124104481801 & Stream & $8 / 02 / 2007$ & 8.2 & 2,060 & 1,600 & 25.0 & 197 & 43.1 & 240 & 12.6 & 17.9 & 711 & 181 & 157 & 3.05 & 0.53 & -82.4 & -10.09 \\
\hline
\end{tabular}


[All analyses completed on filtered samples except Field pH, Field SC, Temp, $\delta^{2} \mathrm{H}$, and $\delta^{18} \mathrm{O}$; Site ID, U.S. Geological Survey site identification number; LBI, left-bank inflow; RBI, right-bank inflow; SC, specific conductance in microSiemens per centimeter at 25 degrees Celsius; TDS, total dissolved solids, in $\mathrm{mg} / \mathrm{L}$; Temp, temperature; ${ }^{\circ} \mathrm{C}$, degrees Celsius; Ca, calcium; mg/L, milligrams per liter; $\mathrm{Mg}$, magnesium; $\mathrm{Na}$, sodium; Se, selenium; $\mu \mathrm{g} / \mathrm{l}$, micrograms per liter; $\mathrm{U}$, uranium; $\mathrm{SO}$, sulfate; $\mathrm{HCO}$, bicarbonate; $\mathrm{Cl}$, chloride; $\mathrm{Br}$, bromide; $\mathrm{NO}_{2}+\mathrm{NO}$, nitrite plus nitrate; $\mathrm{N}$, nitrogen; $\delta^{2} \mathrm{H}$, stable isotope ratio of hydrogen $\left({ }^{2} \mathrm{H}\right.$ and $\left.{ }^{1} \mathrm{H}\right)$ relative to Vienna Standard Mean Ocean Water; $\delta^{18} \mathrm{O}$, stable isotope ratio of oxygen $\left({ }^{18} \mathrm{O}\right.$ and $\left.{ }^{16} \mathrm{O}\right)$ relative to Vienna Standard Mean Ocean Water; blank, no data]

\begin{tabular}{|c|c|c|c|c|c|c|c|c|c|c|c|c|c|c|c|c|c|c|}
\hline Site ID & Source & $\begin{array}{c}\text { Sample } \\
\text { Date }\end{array}$ & $\begin{array}{c}\text { Field } \\
\mathrm{pH}\end{array}$ & $\begin{array}{l}\text { Field } \\
\text { SC }\end{array}$ & $\begin{array}{c}\text { TDS } \\
\text { (mg/L) }\end{array}$ & $\begin{array}{c}\text { Temp } \\
\left({ }^{\circ} \mathrm{C}\right)\end{array}$ & $\begin{array}{c}\mathrm{Ca} \\
(\mathrm{mg} / \mathrm{L})\end{array}$ & $\begin{array}{c}\mathrm{Mg} \\
(\mathrm{mg} / \mathrm{L})\end{array}$ & $\begin{array}{c}\mathrm{Na} \\
(\mathrm{mg} / \mathrm{L})\end{array}$ & $\begin{array}{c}\text { Se } \\
(\mu \mathrm{g} / \mathrm{L})\end{array}$ & $\begin{array}{c}\mathbf{U} \\
(\mu \mathrm{g} / \mathrm{L})\end{array}$ & $\begin{array}{c}\mathrm{SO}_{4} \\
(\mathrm{mg} / \mathrm{L})\end{array}$ & $\begin{array}{c}\mathrm{HCO}_{3} \\
(\mathrm{mg} / \mathrm{L})\end{array}$ & $\begin{array}{c}\text { CI } \\
\text { (mg/L) }\end{array}$ & $\begin{array}{c}\mathrm{Br} \\
\text { (mg/L) }\end{array}$ & $\begin{array}{c}\mathrm{NO}_{2}+\mathrm{NO}_{3} \\
\text { as } \mathrm{N} \\
(\mathrm{mg} / \mathrm{L})\end{array}$ & $\begin{array}{c}\delta^{2} \mathbf{H} \\
\text { (per mil) }\end{array}$ & $\begin{array}{c}\delta^{18} \mathbf{0} \\
\text { (per mil) }\end{array}$ \\
\hline 394124104481802 & LBI & $8 / 02 / 2007$ & 7.9 & 4,420 & 3,930 & 15.0 & 398 & 59.5 & 683 & 56.3 & 46.2 & 2230 & 287 & 160 & 1.43 & 5.34 & -100 & -12.99 \\
\hline 394130104481801 & Stream & $8 / 02 / 2007$ & 8.2 & 2,030 & 1,520 & 25.0 & 185 & 39.3 & 227 & 11.3 & 16.3 & 663 & 172 & 156 & 3.09 & & & \\
\hline 394131104481801 & LBI & $8 / 02 / 2007$ & 8.4 & 665 & 509 & 20.0 & 71.8 & 17.6 & 50.5 & 5.2 & 10.1 & 181 & 133 & 37.1 & 0.13 & & & \\
\hline 394134104481701 & Stream & $8 / 02 / 2007$ & 8.2 & 2,010 & 1,490 & 25.0 & 184 & 39.0 & 225 & 11.7 & 16.3 & 654 & 172 & 157 & 3.05 & & & \\
\hline 394141104481901 & Stream & $8 / 02 / 2007$ & 8.1 & 1,990 & 1,490 & 24.0 & 179 & 37.2 & 222 & 12.2 & 17.0 & 659 & 176 & 158 & 2.84 & & & \\
\hline 394146104482101 & Stream & $8 / 02 / 2007$ & 8 & 1,980 & 1,500 & 23.0 & 171 & 35.5 & 215 & 13.8 & 16.6 & 657 & 179 & 157 & 2.82 & 0.58 & -82.8 & -10.15 \\
\hline 394153104482101 & Stream & $8 / 02 / 2007$ & 7.9 & 2,080 & 1,590 & 21.0 & 200 & 40.5 & 226 & 13.2 & 18.8 & 720 & 193 & 143 & 2.69 & & & \\
\hline 394200104482101 & Stream & $8 / 02 / 2007$ & 7.9 & 2,050 & 1,630 & 21.0 & 214 & 41.7 & 240 & 12.5 & 20.7 & 757 & 212 & 138 & 2.51 & & & \\
\hline 394205104482001 & Stream & $8 / 02 / 2007$ & 7.9 & 2,050 & 1,520 & 20.0 & 205 & 39.8 & 225 & 11.6 & 20.9 & 705 & 223 & 133 & 2.26 & & & \\
\hline 394205104482002 & LBI & $8 / 02 / 2007$ & 8.2 & 2,470 & 2,510 & 17.0 & 298 & 45.4 & 377 & 24.0 & 63.6 & 1270 & 288 & 151 & 0.73 & 2.90 & -95.6 & -12.28 \\
\hline 394210104482001 & Stream & $8 / 02 / 2007$ & 7.8 & 2,020 & 1,550 & 21.0 & 199 & 39.0 & 215 & 11.1 & 18.8 & 695 & 232 & 136 & 2.41 & 0.63 & -82.6 & -10.06 \\
\hline 394210104482002 & RBI & $8 / 02 / 2007$ & 7.5 & 1,680 & 1,270 & 19.0 & 157 & 32.0 & 182 & 7.9 & 14.6 & 587 & 170 & 116 & 2.00 & & & \\
\hline 394218104482101 & Stream & $8 / 02 / 2007$ & 8 & 2,060 & 1,590 & 21.0 & 196 & 40.7 & 220 & 12.9 & 20.6 & 720 & 218 & 141 & 2.55 & 0.51 & -82.6 & -10.02 \\
\hline 394223104482201 & Stream & $8 / 02 / 2007$ & 8 & 1,780 & 1,590 & 21.0 & 199 & 40.6 & 233 & 11.5 & 21.7 & 737 & 208 & 140 & 2.50 & & & \\
\hline 394223104482202 & LBI & $8 / 02 / 2007$ & 7.8 & 962 & 656 & 18.0 & 94 & 21.7 & 70.1 & 0.4 & 6.5 & 172 & 175 & 102 & 0.19 & & & \\
\hline 394227104482101 & Stream & $8 / 02 / 2007$ & 7.8 & 2,020 & 1,560 & 21.0 & 182 & 36.9 & 216 & 12.4 & 17.9 & 707 & 191 & 133 & 2.40 & 0.55 & -80.3 & -9.76 \\
\hline 394230104482001 & RBI & $8 / 02 / 2007$ & 8.3 & 238 & 472 & 18.0 & 57.6 & 11.0 & 55 & 0.6 & 2.2 & 88.6 & 143 & 58.4 & 0.09 & 0.24 & -92.7 & -11.09 \\
\hline 394231104482001 & Stream & $7 / 29 / 2007$ & 8.2 & 1,600 & 1,180 & 25.5 & 160 & 30.4 & 155 & 8.1 & 16.1 & 544 & 189 & 98.1 & 0.63 & 0.42 & -78.6 & -9.88 \\
\hline 394231104482001 & Stream & $8 / 02 / 2007$ & 7.7 & 1,960 & 1,480 & 20.5 & 187 & 38.0 & 223 & 15.2 & 19.0 & 693 & 180 & 129 & 2.26 & 0.59 & -78.6 & -9.59 \\
\hline 394242104481801 & Stream & $7 / 29 / 2007$ & 8.2 & 1,620 & 1,200 & 25.0 & 158 & 30.0 & 154 & 8.4 & 15.9 & 526 & 180 & 94.4 & 1.38 & & & \\
\hline 394242104481801 & Stream & $8 / 02 / 2007$ & 8 & 2,020 & 1,530 & 20.0 & 199 & 38.6 & 225 & 11.8 & 18.1 & 705 & 188 & 129 & 2.32 & & & \\
\hline 394243104481701 & RBI & $7 / 29 / 2007$ & 7.4 & 2,500 & 1,940 & 15.5 & 350 & 50.0 & 177 & 6.3 & 32.1 & 565 & 214 & 395 & 0.92 & & & \\
\hline 394244104481901 & Stream & $7 / 292007$ & 8.2 & 1,600 & 1,200 & 25.5 & 155 & 30.0 & 155 & 8.4 & 16.5 & 528 & 179 & 96 & 1.35 & & & \\
\hline 394243104482801 & Stream & 7/292007 & 8.2 & 1,590 & 1,100 & 25.5 & 155 & 29.7 & 155 & 8.1 & 15.4 & 523 & 176 & 97 & 1.34 & 0.36 & -79.8 & -9.82 \\
\hline 394247104483301 & Stream & $7 / 292007$ & 8.2 & 1,580 & 1,140 & 25.0 & 152 & 29.2 & 156 & 8.3 & 16.5 & 519 & 174 & 97.8 & 1.25 & & & \\
\hline 394254104483501 & Stream & $7 / 292007$ & 8.2 & 1,550 & 1,130 & 25.0 & 148 & 28.0 & 150 & 8.3 & 15.5 & 504 & 171 & 97 & 1.23 & & & \\
\hline 394302104483901 & Stream & $7 / 292007$ & 8.2 & 1,520 & 1,110 & 25.0 & 144 & 27.2 & 144 & 8.2 & 13.8 & 493 & 166 & 93 & 1.14 & & & \\
\hline 394308104484101 & Stream & $7 / 292007$ & 8.2 & 1,500 & 1,080 & 24.5 & 144 & 27.3 & 144 & 7.9 & 13.4 & 469 & 166 & 92.3 & 1.11 & & & \\
\hline 394310104484501 & Stream & $7 / 292007$ & 8.2 & 1,510 & 1,110 & 24.5 & 143 & 26.7 & 144 & 8.1 & 13.7 & 476 & 168 & 94.9 & 1.17 & & & \\
\hline 394310104484601 & LBI & $7 / 292007$ & 8.1 & 2,500 & 1,870 & 18.5 & 232 & 32.0 & 344 & 36.7 & 33.8 & 917 & 223 & 166 & 0.92 & 3.81 & -92.5 & -11.65 \\
\hline 394313104484301 & Stream & 7/292007 & 8.2 & 1,480 & 1,110 & 24.0 & 146 & 27.1 & 152 & 8.9 & 13.9 & 484 & 169 & 96.3 & 1.11 & & & \\
\hline 394314104484801 & Stream & $7 / 292007$ & 8.2 & 1,500 & 1,080 & 23.5 & 144 & 26.0 & 151 & 8.3 & 14.0 & 485 & 169 & 98.5 & 1.08 & & & \\
\hline 394314104485201 & Stream & 7/292007 & 8.2 & 1,470 & 1,020 & 23.5 & 146 & 26.7 & 149 & 8.8 & 13.0 & 479 & 168 & 96.8 & 1.04 & 0.46 & -78.7 & -9.88 \\
\hline 394314104485202 & RBI & $7 / 292007$ & 8.1 & 1,870 & 1,350 & 19.5 & 174 & 30.7 & 194 & 5.1 & 13.0 & 550 & 190 & 172 & 0.85 & 0.32 & -93.6 & -11.54 \\
\hline
\end{tabular}


Table 5. Selected analytical results for synoptic surface-water samples, Toll Gate Creek, July-August 2007.—Continued

[All analyses completed on filtered samples except Field pH, Field SC, Temp, $\delta^{2} \mathrm{H}$, and $\delta^{18} \mathrm{O}$; Site ID, U.S. Geological Survey site identification number; LBI, left-bank inflow; RBI, right-bank inflow; SC, specific conductance in microSiemens per centimeter at 25 degrees Celsius; TDS, total dissolved solids, in mg $/ \mathrm{L}$; Temp, temperature; ${ }^{\circ} \mathrm{C}$, degrees Celsius; Ca, calcium; mg/L, milligrams per liter; $\mathrm{Mg}$, magnesium; $\mathrm{Na}$, sodium; Se, selenium; $\mu \mathrm{g} / 1$, micrograms per liter; $\mathrm{U}$, uranium; $\mathrm{SO}_{4}$, sulfate; $\mathrm{HCO}_{3}$, bicarbonate; $\mathrm{Cl}$, chloride; $\mathrm{Br}$, bromide; $\mathrm{NO}_{2}+\mathrm{NO}_{3}$, nitrite plus nitrate; $\mathrm{N}$, nitrogen; $\delta^{2} \mathrm{H}$, stable isotope ratio of hydrogen $\left({ }^{2} \mathrm{H}\right.$ and $\left.{ }^{1} \mathrm{H}\right)$ relative to Vienna Standard Mean Ocean Water; $\delta^{18} \mathrm{O}$, stable isotope ratio of oxygen $\left({ }^{18} \mathrm{O}\right.$ and $\left.{ }^{16} \mathrm{O}\right)$ relative to Vienna Standard Mean Ocean Water; blank, no data]

\begin{tabular}{|c|c|c|c|c|c|c|c|c|c|c|c|c|c|c|c|c|c|c|}
\hline Site ID & Source & $\begin{array}{c}\text { Sample } \\
\text { Date }\end{array}$ & $\begin{array}{c}\text { Field } \\
\mathrm{pH}\end{array}$ & $\begin{array}{l}\text { Field } \\
\text { SC }\end{array}$ & $\begin{array}{c}\text { TDS } \\
\text { (mg/L) }\end{array}$ & $\begin{array}{c}\text { Temp } \\
\left({ }^{\circ} \mathrm{C}\right)\end{array}$ & $\begin{array}{c}\mathrm{Ca} \\
(\mathrm{mg} / \mathrm{L})\end{array}$ & $\underset{(\mathrm{mg} / \mathrm{L})}{\mathrm{Mg}}$ & $\underset{(\mathrm{mg} / \mathrm{L})}{\mathrm{Na}}$ & $\begin{array}{c}\mathrm{Se} \\
(\mu \mathrm{g} / \mathrm{L})\end{array}$ & $\underset{(\mu g / L)}{U}$ & $\begin{array}{c}\mathrm{SO}_{4} \\
(\mathrm{mg} / \mathrm{L})\end{array}$ & $\begin{array}{c}\mathrm{HCO}_{3} \\
\text { (mg/L) }\end{array}$ & $\begin{array}{c}\mathrm{Cl} \\
(\mathrm{mg} / \mathrm{L})\end{array}$ & $\begin{array}{c}\mathrm{Br} \\
(\mathrm{mg} / \mathrm{L})\end{array}$ & $\begin{array}{c}\mathrm{NO}_{2}+\mathrm{NO}_{3} \\
\text { as } \mathrm{N} \\
(\mathrm{mg} / \mathrm{L})\end{array}$ & $\begin{array}{c}\delta^{2} \mathbf{H} \\
\text { (per mil) }\end{array}$ & $\begin{array}{c}\delta^{18} 0 \\
\text { (per mil) }\end{array}$ \\
\hline 394314104485601 & Stream & $7 / 292007$ & 8.2 & 1,500 & 1,040 & 23.0 & 144 & 26.3 & 149 & 7.9 & 13.2 & 479 & 169 & 99.1 & 1.06 & 0.46 & -79.5 & -9.94 \\
\hline 394317104485501 & Stream & $7 / 292007$ & 8.2 & 1,480 & 1,060 & 22.5 & 142 & 25.8 & 143 & 8.3 & 13.1 & 456 & 167 & 96.6 & 1.03 & & & \\
\hline 394323104485801 & Stream & $7 / 292007$ & 8.2 & 1,440 & 1,060 & 22.0 & 135 & 24.6 & 139 & 7.8 & 12.7 & 447 & 165 & 94.6 & 0.99 & & & \\
\hline 394323104490201 & LBI & $7 / 292007$ & 8.1 & 879 & 1,050 & 21.5 & 127 & 13.8 & 173 & 10.1 & 18.4 & 388 & 117 & 170 & 0.82 & & & \\
\hline 394330104490501 & Stream & $7 / 292007$ & 8.2 & 1,440 & 972 & 21.5 & 136 & 24.5 & 143 & 7.7 & 11.6 & 442 & 163 & 94.8 & 1.00 & 0.47 & -79.1 & -9.92 \\
\hline 394332104490701 & LBI & $7 / 292007$ & 8.3 & 2,220 & 2,920 & 17.5 & 309 & 33.9 & 570 & 60.5 & 82.2 & 1280 & 229 & 366 & 1.68 & & & \\
\hline 394336104490501 & Stream & $7 / 26 / 2007$ & 8.4 & 2,400 & 1,660 & 27.5 & 213 & 39.9 & 257 & 15.0 & 21.0 & 809 & 170 & 157 & 1.01 & 0.51 & -81.3 & -9.88 \\
\hline 394336104490501 & Stream & $7 / 29 / 2007$ & 8.2 & 1,460 & 1,020 & 20.5 & 135 & 24.7 & 145 & 7.8 & 12.6 & 450 & 165 & 99.2 & 0.99 & 0.57 & -78.5 & -9.89 \\
\hline 394343104491101 & Stream & $7 / 26 / 2007$ & 8.4 & 2,360 & 1,640 & 28.5 & 206 & 39.0 & 248 & 10.8 & 13.8 & 796 & 161 & 154 & 0.93 & & & \\
\hline 394343104491101 & Stream & $7 / 29 / 2007$ & 8.1 & 1,450 & 1,040 & 20.5 & 133 & 23.7 & 146 & 7.8 & 13.8 & 441 & 163 & 98.6 & 0.92 & & & \\
\hline 394348104491801 & Stream & $7 / 26 / 2007$ & 8.5 & 2,370 & 1,630 & 29.5 & 211 & 40.5 & 252 & 15.9 & 20.9 & 795 & 155 & 153 & 0.91 & & & \\
\hline 394355104491901 & Stream & $7 / 26 / 2007$ & 8.4 & 2,380 & 1,600 & 29.0 & 211 & 40.2 & 255 & 16.1 & 21.5 & 792 & 157 & 152 & 0.93 & & & \\
\hline 394359104493001 & Stream & $7 / 26 / 2007$ & 8.4 & 2,320 & 1,620 & 27.5 & 206 & 38.8 & 244 & 13.7 & 21.1 & 786 & 170 & 150 & 0.94 & 0.38 & -82.2 & -9.95 \\
\hline 394406104493501 & Stream & $7 / 26 / 2007$ & 8.4 & 2,360 & 1,620 & 27.0 & 203 & 38.6 & 241 & 15.1 & 21.6 & 784 & 165 & 151 & 2.33 & & & \\
\hline 394414104493401 & Stream & $7 / 26 / 2007$ & 8.4 & 2,340 & 1,630 & 26.5 & 215 & 40.1 & 252 & 14.1 & 21.6 & 784 & 177 & 151 & 2.35 & & & \\
\hline 394423104493501 & Stream & $7 / 26 / 2007$ & 8.5 & 2,340 & 1,610 & 27.0 & 204 & 38.9 & 243 & 13.2 & 21.1 & 782 & 167 & 151 & 2.30 & 0.32 & -80.9 & -9.7 \\
\hline 394424104493501 & RBI & $7 / 26 / 2007$ & 8 & 2,680 & 1,900 & 15.5 & 222 & 33.7 & 317 & 55.0 & 48.0 & 910 & 273 & 153 & 1.05 & 6.88 & -99.4 & -13.15 \\
\hline 394432104493601 & Stream & $7 / 26 / 2007$ & 8.4 & 2,360 & 1,610 & 25.5 & 216 & 40.3 & 259 & 15.3 & 22.5 & 786 & 172 & 151 & 2.16 & 0.73 & -82.0 & -9.86 \\
\hline 394432104493602 & RBI & $7 / 26 / 2007$ & 7.4 & 2,440 & 1,650 & 16.0 & 284 & 32.0 & 218 & 10.9 & 26.5 & 579 & 388 & 211 & 1.04 & 3.27 & -99.2 & -12.93 \\
\hline 394439104494001 & Stream & $7 / 26 / 2007$ & 8.3 & 2,330 & 1,620 & 24.0 & 209 & 37.8 & 250 & 15.4 & 22.1 & 780 & 181 & 151 & 2.00 & 0.71 & -80.3 & -9.73 \\
\hline 394441104493901 & RBI & $7 / 26 / 2007$ & 7.2 & 2,800 & 2,050 & 15.0 & 305 & 37.0 & 323 & 21.1 & 40.9 & 735 & 447 & 304 & 1.20 & 4.71 & -103 & -13.42 \\
\hline 394446104494201 & Stream & $7 / 26 / 2007$ & 8.4 & 2,350 & 1,640 & 23.0 & 207 & 38.1 & 249 & 17.6 & 22.3 & 775 & 182 & 152 & 1.95 & & & \\
\hline 394455104494201 & Stream & $7 / 26 / 2007$ & 8.3 & 2,350 & 1,650 & 23.0 & 206 & 36.8 & 248 & 16.2 & 22.0 & 775 & 186 & 154 & 1.87 & & & \\
\hline 394502104494401 & Stream & $7 / 26 / 2007$ & 8.3 & 2,320 & 1,800 & 23.0 & 203 & 36.4 & 246 & 15.5 & 21.7 & 745 & 185 & 150 & 1.75 & & & \\
\hline 394502104494402 & RBI & $7 / 26 / 2007$ & 6.9 & 2,760 & 1,910 & 23.0 & 292 & 32.8 & 319 & 8.9 & 62.0 & 609 & 446 & 295 & 1.08 & 6.11 & -103 & -13.52 \\
\hline 394504104494401 & RBI & $7 / 26 / 2007$ & 7.8 & 1,780 & 1,140 & 22.0 & 132 & 28.7 & 186 & 3.5 & 23.6 & 572 & 127 & 96.5 & 0.59 & 0.06 & -91.8 & -11 \\
\hline 394504104494402 & Stream & $7 / 26 / 2007$ & 8.2 & 2,320 & 1,600 & 22.5 & 213 & 38.3 & 256 & 14.3 & 20.8 & 747 & 198 & 152 & 1.81 & 0.80 & -78.5 & -9.52 \\
\hline 394505104494401 & RBI & $7 / 26 / 2007$ & 7.6 & 2,260 & 1,450 & 16.0 & 186 & 29.1 & 243 & 0.8 & 19.6 & 484 & 308 & 200 & 0.61 & & & \\
\hline 394507104495001 & Stream & $7 / 26 / 2007$ & 8.2 & 2,260 & 1,580 & 22.5 & 202 & 35.9 & 242 & 13.7 & 20.0 & 709 & 193 & 147 & 1.62 & & & \\
\hline 394509104495301 & LBI & $7 / 26 / 2007$ & 7.5 & 1,440 & 1,040 & 20.3 & 148 & 19.9 & 113 & 6.5 & 10.3 & 361 & 212 & 78.8 & 0.63 & 1.89 & -68.7 & -7.62 \\
\hline 394516104495801 & Stream & $7 / 26 / 2007$ & 8.1 & 2,100 & 1,480 & 21.3 & 174 & 31.3 & 215 & 13.4 & 18.1 & 659 & 184 & 142 & 1.68 & & & \\
\hline 394520104500901 & Stream & $7 / 26 / 2007$ & 7.9 & 2,290 & 1,580 & 21.6 & 204 & 36.5 & 252 & 14.2 & 21.9 & 745 & 194 & 153 & 2.53 & 0.70 & -80.6 & -9.6 \\
\hline
\end{tabular}


[All analyses completed on filtered samples except Field pH, Field SC, Temp, $\delta^{2} \mathrm{H}$, and $\delta^{18} \mathrm{O}$ Site ID, USGS Site identification number; SC, specific conductance in microSiemens per centimeter at 25 degrees Celsius; TDS, total dissolved solids, in mg/L; Temp, temperature; ${ }^{\circ} \mathrm{C}$, degrees Celsius; DO, dissolved oxygen; mg/L, milligrams per liter; DOC, dissolved organic carbon, Ca, calcium; Mg, magnesium; Na, sodium; K, potassium; Se, selenium; $\mu \mathrm{g} / \mathrm{L}$, micrograms per liter; $\mathrm{U}$, uranium; $\mathrm{SO}_{4}$, sulfate; $\mathrm{HCO}_{3}$, bicarbonate; $\mathrm{Cl}$, chloride; $\mathrm{Br}$, bromide; $\mathrm{NO}_{2}+\mathrm{NO}_{3}$, nitrite plus nitrate; $\mathrm{N}$, nitrogen; $\delta^{2} \mathrm{H}$, stable isotope ratio of hydrogen $\left({ }^{2} \mathrm{H}\right.$ and $\left.{ }^{1} \mathrm{H}\right)$ relative to Vienna Standard Mean Ocean Water; $\delta^{18} \mathrm{O}$, stable isotope ratio of oxygen $\left({ }^{18} \mathrm{O}\right.$ and $\left.{ }^{16} \mathrm{O}\right)$ relative to Vienna Standard Mean Ocean Water; nd, no data; shaded rows represent data for water samples from wells URLUS-28 (Site ID 393742104453801) and URLUS-30 (Site ID 393903104455701)]

\begin{tabular}{|c|c|c|c|c|c|c|c|c|c|c|c|c|c|c|c|c|c|c|c|c|c|}
\hline Site ID & $\begin{array}{l}\text { Well } \\
\text { name }\end{array}$ & $\begin{array}{l}\text { Sample } \\
\text { date }\end{array}$ & $\begin{array}{c}\text { Field } \\
\mathrm{pH}\end{array}$ & $\begin{array}{l}\text { Field } \\
\text { SC }\end{array}$ & TDS & $\begin{array}{c}\text { Temp } \\
\left({ }^{\circ} \mathrm{C}\right)\end{array}$ & $\begin{array}{c}\mathrm{DO} \\
\text { (mg/L) }\end{array}$ & $\begin{array}{c}\text { DOC } \\
\text { (mg/L) }\end{array}$ & $\begin{array}{c}\mathrm{Ca} \\
\text { (mg/L) }\end{array}$ & $\underset{(\mathrm{mg} / \mathrm{L})}{\mathrm{Mg}}$ & $\begin{array}{c}\mathrm{Na} \\
\text { (mg/L) }\end{array}$ & $\begin{array}{c}\mathrm{K} \\
(\mathrm{mg} / \mathrm{L})\end{array}$ & $\begin{array}{c}\mathrm{Se} \\
(\mu \mathrm{g} / \mathrm{L})\end{array}$ & $\underset{(\mu g / L)}{U}$ & $\begin{array}{c}\mathrm{SO}_{4} \\
\text { (mg/L) }\end{array}$ & $\begin{array}{l}\mathrm{HCO}_{3} \\
\text { (mg/L) }\end{array}$ & $\begin{array}{c}\mathrm{Cl}, \\
\mathrm{mg} / \mathrm{L}\end{array}$ & $\begin{array}{c}\mathrm{Br} \\
(\mathrm{mg} / \mathrm{L})\end{array}$ & $\begin{array}{c}\mathrm{NO}_{2}+\mathrm{NO}_{3} \\
\text { as } \mathrm{N} \\
(\mathrm{mg} / \mathrm{L})\end{array}$ & $\begin{array}{c}\delta^{2} \mathbf{H} \\
\text { (per mil) }\end{array}$ & $\begin{array}{c}\delta^{18} 0 \\
\text { (per mil) }\end{array}$ \\
\hline 394305104482601 & ET-1 & $7 / 30 / 2007$ & 7.1 & 1,630 & 180 & 11.4 & 0.1 & 2.2 & 150 & 2 & 184 & 0.0 & 49 & 9.66 & 10 & 20 & 94.5 & 0.0 & 2.46 & -102 & -13.15 \\
\hline 394305104482301 & ET-2 & $7 / 16 / 2007$ & 7.3 & 1,570 & 1,190 & 12.8 & 0.2 & 1.0 & 208 & 28.1 & 96.6 & 0.79 & 62.5 & 17.3 & 513 & 258 & 73.3 & 0.55 & 4.5 & -102 & -13.12 \\
\hline 393750104415901 & MC-2B & $7 / 17 / 2007$ & 7.1 & 1,640 & 1,290 & 16.8 & 0.1 & 4.6 & 247 & 25.8 & 82.2 & 7.58 & 0.1 & 26 & 453 & 382 & 102 & 0.46 & $<0.06$ & -95.9 & -12.81 \\
\hline 394456104503501 & $\mathrm{SC}-4$ & $7 / 31 / 2007$ & 7.0 & 2,720 & 1,740 & 17.0 & 3.5 & 3.1 & 278 & 34.8 & 355 & 2.66 & 19.3 & 78.3 & 936 & 446 & 128 & 0.63 & 13.6 & -104 & -13.53 \\
\hline 394434104453601 & SC-6 & $7 / 18 / 2007$ & 7.4 & 2,250 & 1,770 & 13.0 & 7.4 & 3.6 & 234 & 33.5 & 278 & 6.22 & 27.9 & 24.9 & 804 & 299 & 92.9 & 0.86 & 10.3 & -97.7 & -12.72 \\
\hline 394525104495401 & SCTC-5 & $7 / 18 / 2007$ & 7.4 & 1,080 & 693 & 12.7 & 0.2 & 3.7 & 93.6 & 12.7 & 119 & 5.12 & 0.3 & 12.7 & 141 & 334 & 94.5 & 0.41 & $<0.06$ & -99.2 & -13.00 \\
\hline 394520104500001 & TC-1 & $7 / 20 / 2007$ & 6.8 & 2,210 & 1,540 & 15.0 & 0.1 & 3.4 & 216 & 32.7 & 264 & 4.29 & 32.4 & 40.5 & 479 & 546 & 172 & 0.89 & 4.89 & -100 & -13.20 \\
\hline 394522104495801 & TC-2 & $7 / 20 / 2007$ & 6.9 & 1,890 & 1,320 & 17.6 & 0.1 & 3.1 & 201 & 28.1 & 174 & 3.94 & 22.6 & 51.4 & 378 & 463 & 149 & 0.63 & 10.5 & -99.6 & -13.18 \\
\hline 393846104465601 & URLUS-18 & $7 / 17 / 2007$ & 7.1 & 1,900 & 1,500 & 15.5 & nd & 1.8 & 242 & 50.1 & 127 & 2.13 & 5.9 & 17.4 & 601 & 341 & 124 & 0.61 & 5.41 & -98.2 & -12.73 \\
\hline 393742104453801 & URL & $7 / 12 / 2007$ & 6.8 & 4,510 & 4,070 & 15.5 & - & - & 631 & 95.9 & 390 & 7.92 & 192 & 10.1 & 2,170 & 238 & 列 & 4.6 & 12.7 & -99.9 & -12.81 \\
\hline 393903104455701 & URLUS-30 & $8 / 6 / 2007$ & 7.3 & 5,080 & 4,400 & 14.6 & 2.0 & (1) & 491 & 88.8 & 665 & 6.43 & 264 & 30 & 2,370 & 184 & 300 & 4.78 & 18.6 & -86.3 & -10.35 \\
\hline 394304104483801 & WT-1 & $7 / 16 / 2007$ & 6.9 & 2,450 & 1,880 & 14.6 & 1.8 & 2.9 & 296 & 40.2 & 200 & 9 & 12.4 & 38.6 & 696 & 368 & 239 & 1.46 & 1.55 & -100 & -13.09 \\
\hline 393903104480701 & WT-11 & $7 / 19 / 2007$ & 7.1 & 1,200 & 787 & 14.2 & 0.6 & 2.4 & 123 & 38.1 & 77.4 & 2.05 & 18.2 & 23.2 & 107 & 478 & 82.6 & 0.36 & 7.81 & -96.9 & -12.93 \\
\hline 394002104483001 & WT-12 & $7 / 19 / 2007$ & 7.3 & 1,020 & 679 & 13.3 & 0.1 & 1.7 & 111 & 22.1 & 75.8 & 1.93 & 6.6 & 15 & 98.1 & 332 & 76.8 & 0.34 & 6.26 & -102 & -13.33 \\
\hline 394040104465701 & WT-14 & $7 / 31 / 2007$ & 7.0 & 3,630 & 2,970 & 17.4 & 1.0 & 5.5 & 481 & 80.5 & 407 & 7.05 & 53 & 99.8 & 1,530 & 542 & 159 & 1.44 & 5.23 & 98.6 & -12.54 \\
\hline 394007104465001 & WT-19 & $7 / 24 / 2007$ & 7.1 & 2,660 & 2,110 & 13.5 & nd & 3.2 & 323 & 45 & 232 & 0.95 & 55.9 & 30.7 & 953 & 407 & 172 & 1.35 & 6.03 & 96.9 & -12.38 \\
\hline 394304104483301 & WT-2 & $7 / 30 / 2007$ & 7.1 & 1,850 & 1,240 & 15.0 & 0.4 & 1.0 & 215 & 30.2 & 150 & 0.97 & 2.8 & 22.3 & 479 & 339 & 171 & 0.76 & 0.12 & -100 & -13.15 \\
\hline 394055104480001 & WT-4 & $7 / 23 / 2007$ & 7.1 & 3,680 & 3,310 & 13.5 & 0.1 & 4.9 & 530 & 84.5 & 316 & 2.24 & 37.2 & 83.3 & 1,730 & 454 & 149 & 1.55 & 7.26 & -101 & -13.20 \\
\hline 393939104453701 & WT-8 & $7 / 23 / 2007$ & 7.1 & 3,650 & 3,230 & 13.2 & 0.1 & 2.8 & 456 & 82.1 & 393 & 0.99 & 51.3 & 31.6 & 1,790 & 318 & 124 & 0.77 & 2.34 & -100 & -13.03 \\
\hline
\end{tabular}


Table 7. Site information for 11 inflow sites with greatest dissolved selenium concentration, Toll Gate Creek, July-August 2007.

[Site ID, U.S. Geological Survey site identification number; Sample ID, synoptic-sample identification number; TG, Toll Gate; WP, waypoint number assigned by Global Positioning System unit; RBI, rightbank inflow; LBI, left bank inflow; in., inch; ft., foot; $\mathrm{m}$, meters; $\approx$, approximately; $\mu \mathrm{g} / \mathrm{L}$,micrograms per liter; $\mathrm{m}$, meter]

\begin{tabular}{|c|c|c|c|c|c|c|c|}
\hline Site ID & Sample ID & Site name & Source & $\begin{array}{l}\text { Distance from } \\
\text { Quincy Reservoir } \\
\text { (meters) }\end{array}$ & Site description & $\begin{array}{c}\text { Selenium } \\
\text { concentration } \\
(\mu \mathrm{g} / \mathrm{L})\end{array}$ & $\begin{array}{l}\text { Selenium } \\
\text { concentration } \\
\text { rank }\end{array}$ \\
\hline 393909104464502 & TG-WP460 & $\begin{array}{l}\text { TG-WP460 right-bank inflow } \\
\text { at WP460 }\end{array}$ & RBI & 1,772 & $\begin{array}{l}\text { Small unnamed creek collecting groundwater } \\
\text { discharge and storm runoff }\end{array}$ & 30.3 & 8 \\
\hline 393921104463901 & TG-WP466 & $\begin{array}{l}\text { TG-WP466 right-bank inflow } \\
\text { at WP466 }\end{array}$ & RBI & 2,181 & $\begin{array}{l}\text { Culvert inflow, } \approx 50 \mathrm{~m} \text { downstream from } \\
\text { Hampden Avenue. Possible former tribu- } \\
\text { tary piped to culvert. }\end{array}$ & 28.0 & 9 \\
\hline 394025104471001 & TG-WP451RLR & $\begin{array}{l}\text { TG-WP451RLR right-bank } \\
\text { inflow at WP451RLR }\end{array}$ & RBI & 4,707 & $\begin{array}{l}\text { Culvert inflow under Iliff Avenue. Possible } \\
\text { former tributary piped to culvert. }\end{array}$ & 78.5 & 1 \\
\hline 394109104481201 & TG-1649 & $\begin{array}{l}\text { TG-1649 left-bank inflow at } \\
1,649 \mathrm{~m}\end{array}$ & LBI & 6,979 & $\begin{array}{l}12 \text { in. culvert } \approx 12 \mathrm{~m} \text { downstream from } \\
\text { Mexico Avenue. Likely former tributary } \\
\text { piped to culvert. }\end{array}$ & 31.5 & 7 \\
\hline 394115104481501 & TG-1859 & $\begin{array}{l}\text { TG-1859 left-bank inflow at } \\
1,859 \mathrm{~m}\end{array}$ & LBI & 7,189 & Former tributary piped to culvert. & 45.0 & 5 \\
\hline 394124104481802 & TG-2165 & $\begin{array}{l}\text { TG-2165 left-bank inflow at } \\
2,165 \mathrm{~m}\end{array}$ & LBI & 7,495 & Contact spring & 56.3 & 3 \\
\hline 394205104482002 & TG-3479 & $\begin{array}{l}\text { TG-3479 left-bank inflow at } \\
3,479 \mathrm{~m}\end{array}$ & LBI & 8,809 & $\begin{array}{l}\text { Large cement culvert. Likely former tributary } \\
\text { piped to culvert }\end{array}$ & 24.0 & 10 \\
\hline 394310104484601 & TGM-6373 & $\begin{array}{l}\text { TG-6373 left-bank inflow at } \\
6,373 \mathrm{~m}\end{array}$ & LBI & 11,703 & $\approx 4 \mathrm{ft}$ culvert near Dearborn Street & 36.7 & 6 \\
\hline 394332104490701 & TGM-7890 & $\begin{array}{l}\text { TG-7890 left-bank inflow at } \\
7,890 \mathrm{~m}\end{array}$ & LBI & 13,220 & $\begin{array}{l}\approx 4 \mathrm{ft} \text { culvert at downstream side of } 6 \mathrm{th} \\
\text { Avenue. Former tributary piped to culvert. }\end{array}$ & 60.5 & 2 \\
\hline 394424104493501 & TG-9989 & $\begin{array}{l}\text { TG-9989 right-bank inflow at } \\
\text { 9,989 m }\end{array}$ & RBI & 15,319 & $\begin{array}{l}\text { Box culvert, } \approx 10 \text { m upstream from Colfax } \\
\text { Avenue }\end{array}$ & 55.0 & 4 \\
\hline 394441104493901 & TG-10557 & $\begin{array}{l}\text { TG-10557 right-bank inflow } \\
\text { at } 10,557 \mathrm{~m}\end{array}$ & RBI & 15,887 & Contact spring & 21.1 & 11 \\
\hline
\end{tabular}


compounds also can be precipitated as selenium-bearing salts along streambanks as evapotranspiration occurs, and selenium-bearing evaporative salts were identified along Toll Gate Creek by Herring and Walton-Day (2007). Where reducing conditions are present in wetland areas or stagnant stream reaches, selenium can be reduced to insoluble forms such as selenide and can be removed from the water column by precipitation of selenium-bearing sulfide minerals or by adsorption onto and (or) uptake into organic matter. The presence of large algal blooms and abundant macrophytes, in conjuction with the attenuation of selenium and nitrate (see sections "nitrate") in surface water, indicates that plant uptake was likely decreasing stream selenium concentrations during the summer low-flow study period.

Concentrations of selenium in groundwater were, in general, substantially greater than inflow and stream selenium concentrations and the Colorado aquatic-life standard of $4.6 \mu \mathrm{g} / \mathrm{L}$, and at some locations were greater than the
USEPA primary drinking-water standard of $50 \mu \mathrm{g} / \mathrm{L}$ (figs. 22 and 23). Groundwater selenium concentrations ranged from a minimum of $0.1 \mu \mathrm{g} / \mathrm{L}$ at well $\mathrm{MC}-2 \mathrm{~B}$ to a maximum of $264 \mu \mathrm{g} / \mathrm{L}$ at well URLUS-30, with a mean value of $48.1 \mu \mathrm{g} / \mathrm{L}$ and a median value of $27.9 \mu \mathrm{g} / \mathrm{L}$ (table 6; fig. 22). Concentrations of selenium in groundwater are of the same order of magnitude as the 11 inflows with the greatest selenium concentrations, 2 of which are springs (table 7). The mean $(18.1 \mu \mathrm{g} / \mathrm{L})$ and median $(8.6 \mu \mathrm{g} / \mathrm{L})$ inflow selenium concentrations and the mean $(10.9 \mu \mathrm{g} / \mathrm{L})$ and median $(11.5 \mu \mathrm{g} / \mathrm{L})$ stream selenium concentrations are less than those for groundwater (fig. 22). Stream selenium concentrations range from 3.0 to $19.0 \mu \mathrm{g} / \mathrm{L}$ (a span of $16.0 \mu \mathrm{g} / \mathrm{L}$ ) exhibiting less variability than inflow or groundwater selenium concentrations indicating that hydrological, geochemical, and biological instream processes were effectively mixing the inflow and groundwater discharge received by the stream during summer low-flow conditions.

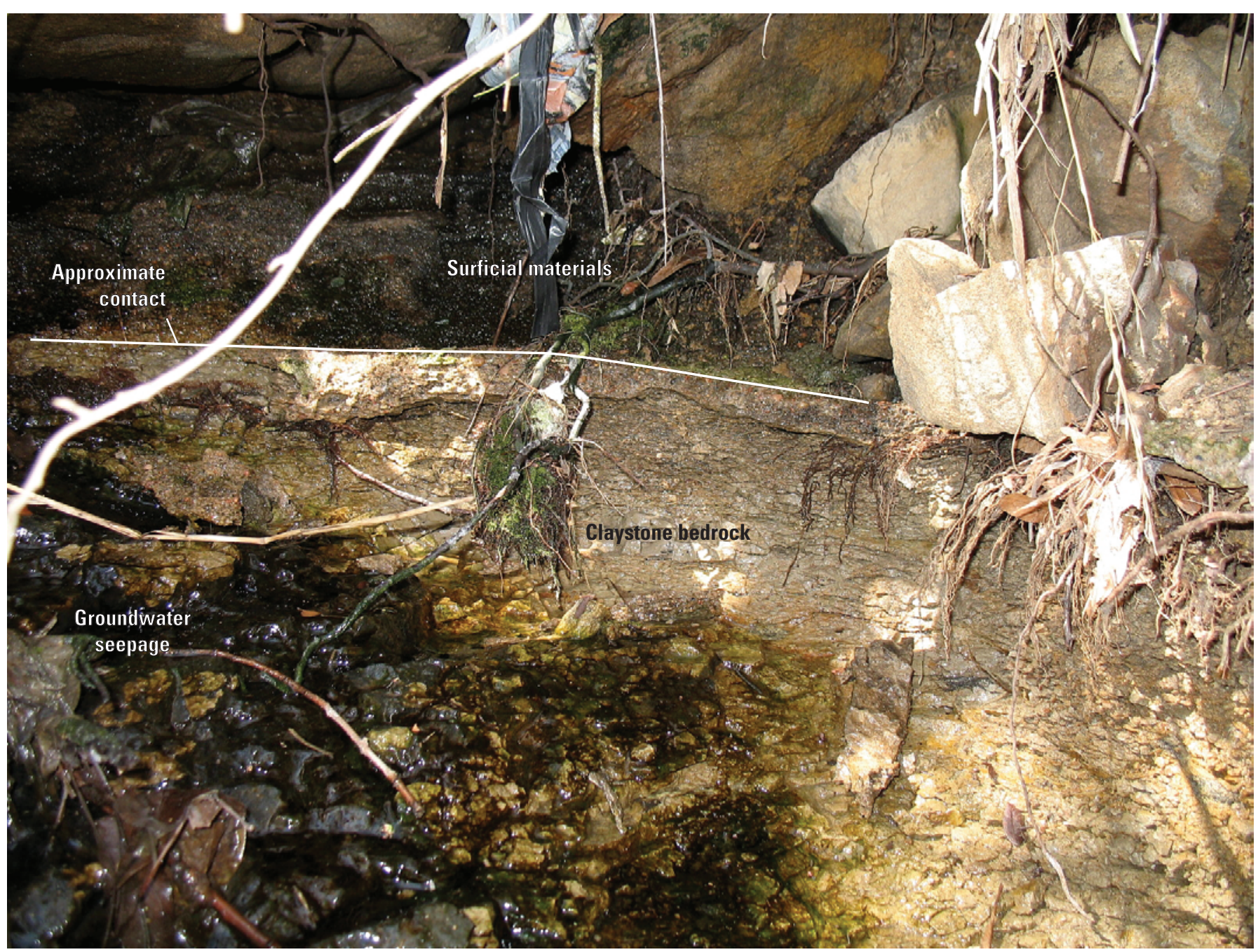

Figure 20. Photograph showing left-bank inflow TG-2165, groundwater discharge along the contact between surficial materials and underlying claystone bedrock, March 2008 (Photograph by Suzanne Paschke). 


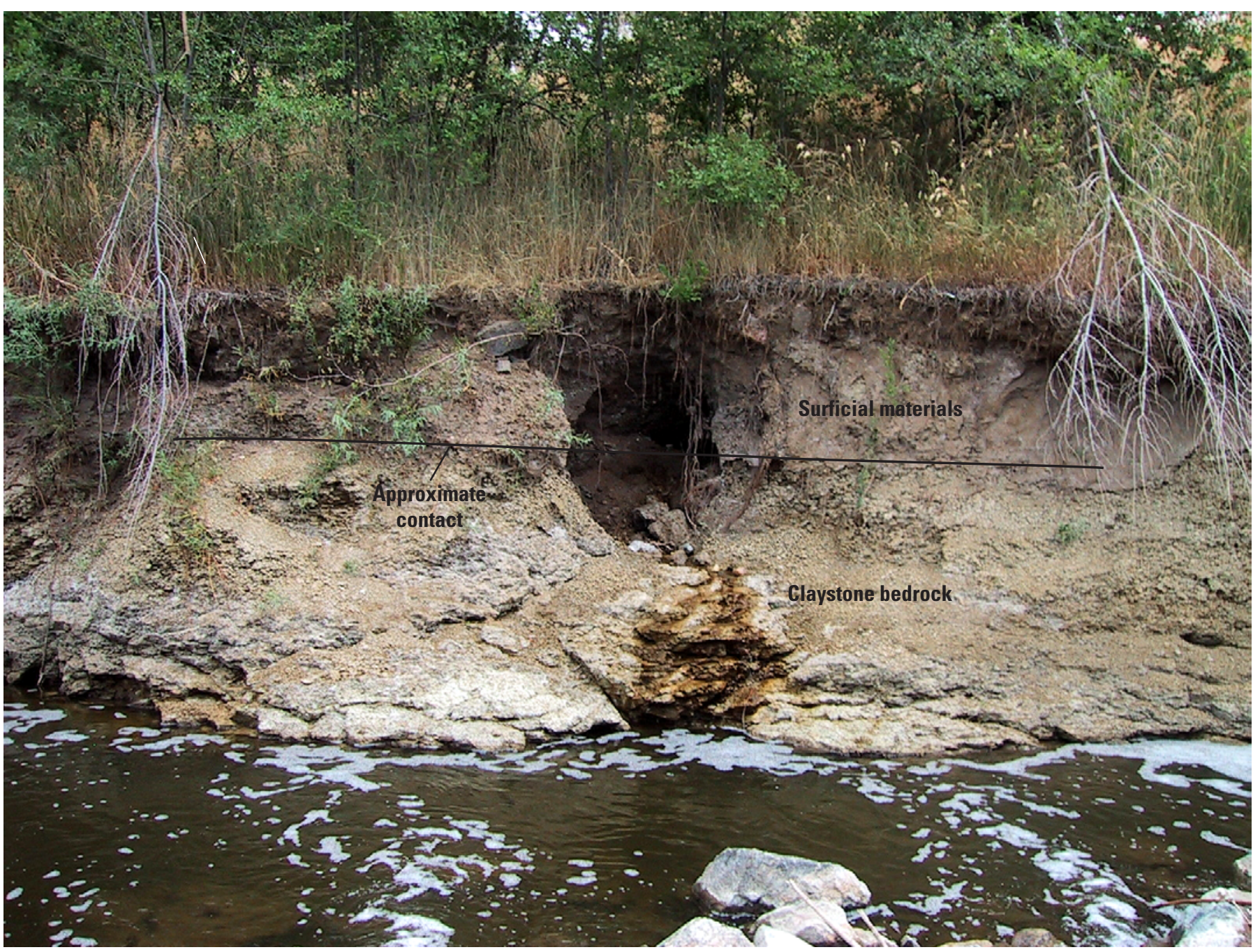

Figure 21. Photograph showing right-bank inflow TG-10557, groundwater discharge along the contact between surficial materials and underlying claystone bedrock, July 2008 (Photograph by Suzanne Paschke).

Spatially, concentrations of selenium in groundwater greater than $50 \mu \mathrm{g} / \mathrm{L}$ generally occurred in wells upgradient of West Toll Gate Creek in areas where the Denver Formation crops out at the land surface (fig. 23). For the inflows that are springs, the greatest selenium concentrations (21 and $56 \mu \mathrm{g} / \mathrm{L}$ ) occurred near the western extent of the Denver Formation outcrop area downstream from Buckley Road (fig. 23), also indicating that groundwater discharge from bedrock to Toll Gate Creek contributes to selenium load. The distribution of the 11 inflows with the greatest selenium concentrations indicates that in addition to the springs downstream from Buckley Road, culverts that drain parts of the watershed downstream from 6th Avenue also contribute selenium load to Toll Gate Creek. The distribution of selenium concentrations in groundwater, springs, and the 11 inflows with the greatest selenium concentrations indicates that groundwater in surficial materials and the Denver Formation bedrock is a source of selenium loading to Toll Gate Creek and that selenium loading from groundwater discharge and surface-water tributaries is distributed along the entire length of the study reach downstream from the concrete-lined channel. Where the stream is incised and flows directly on bedrock, selenium also can be mobilized directly to surface water by oxidation and (or) dissolution processes.

The maximum dissolved selenium concentrations in groundwater of $264 \mu \mathrm{g} / \mathrm{L}$ and $192 \mu \mathrm{g} / \mathrm{L}$ occurred at wells URLUS-30 (Site ID 393903104455701) and URLUS-28 (Site ID 393742104453801), respectively (table 6). These wells are located upgradient, east and south, respectively, of the Toll Gate Creek study reach (fig. 23) and are completed in bedrock materials. Water quality at these two wells is substantially different than at other sampled well locations 


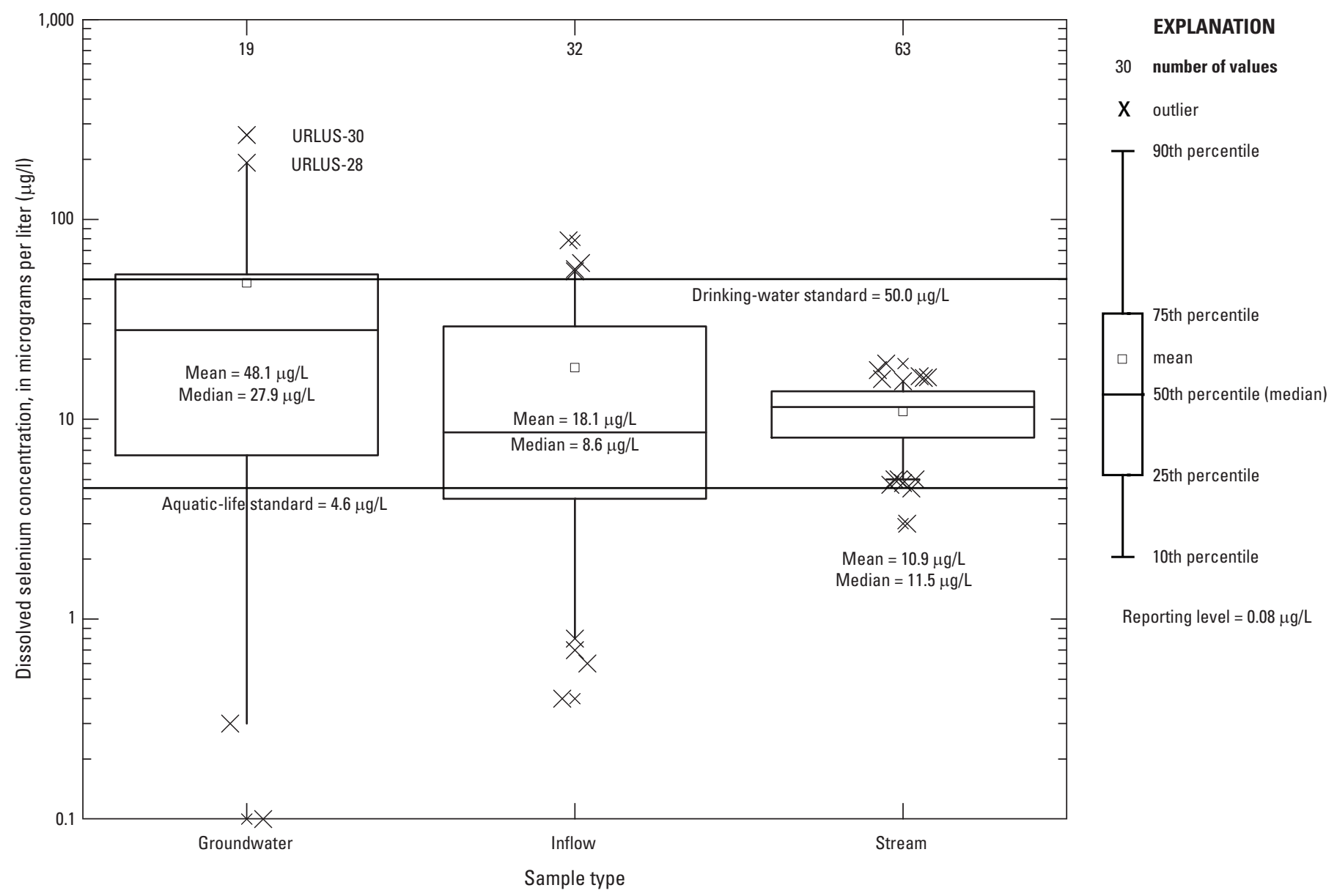

Figure 22. Boxplot showing distribution of dissolved selenium concentrations, in micrograms per liter, for groundwater, inflow, and stream samples, Toll Gate Creek, July-August 2007. Sample names indicated for groundwater upper outliers.

and is characterized by selenium concentrations ranging from 192 to $264 \mu \mathrm{g} / \mathrm{L}$, total dissolved solids (TDS) values ranging from 4,070 to $4,400 \mathrm{mg} / \mathrm{L}$, dissolved-oxygen concentrations of about $2 \mathrm{mg} / \mathrm{L}$, DOC concentrations ranging from 8.2 to $9.9 \mathrm{mg} / \mathrm{L}$, sodium concentrations ranging from 390 to $665 \mathrm{mg} / \mathrm{L}$, sulfate concentrations ranging from 2,170 to $2,370 \mathrm{mg} / \mathrm{L}$, chloride concentrations of about $300 \mathrm{mg} / \mathrm{L}$, bromide concentrations greater than $4 \mathrm{mg} / \mathrm{L}$, nitrate concentrations ranging from 12.7 to $18.6 \mathrm{mg} / \mathrm{L}$ (table 6), and mixed groundwater ages (discussed in the "Apparent Groundwater Ages and Recharge Rates" section of this report). Well URLUS-30 is completed 28 to 37.5 feet below land surface in weathered Denver claystone at a location where the water table occurs in the weathered bedrock. Core from the well is described as "yellow-brown to olive-gray claystone with iron staining and gypsum" (Jennifer Beck, U.S. Geological Survey, written commun., 2003). Well URLUS-28 is completed 18.3-28.1 feet below land surface in a dark gray wetland clay, underlain by weathered claystone bedrock. (Jennifer Beck, U.S. Geological Survey, written commun., 2003).

\section{Surface-Water Selenium Loads}

Dissolved selenium loads calculated using equation 1 are presented in figure 24. As with the final streamflow estimates (see "Streamflow Conditions"), specific conclusions based on individual values and point-to-point comparisons are not appropriate because of potential temporal variation in concentration and streamflow (see "Effects of Increased Streamflow on Constituent Concentrations," fig. 16, and Appendix 1). In lieu of specific conclusions, the appropriate focus is the general pattern of selenium loading over the length of the study reach. The general pattern of selenium loading within the study reach is a steady downstream increase in mass load (fig. 24). This steady increase is consistent with the spatial distribution of inflows with the greatest selenium concentration (see "Selenium Concentrations" section), contributions from diffuse groundwater discharge, and the steady downstream increase in streamflow (fig. 17). Further, the smooth transition of the loading profile from one subreach to the next indicates that the loading analysis is 


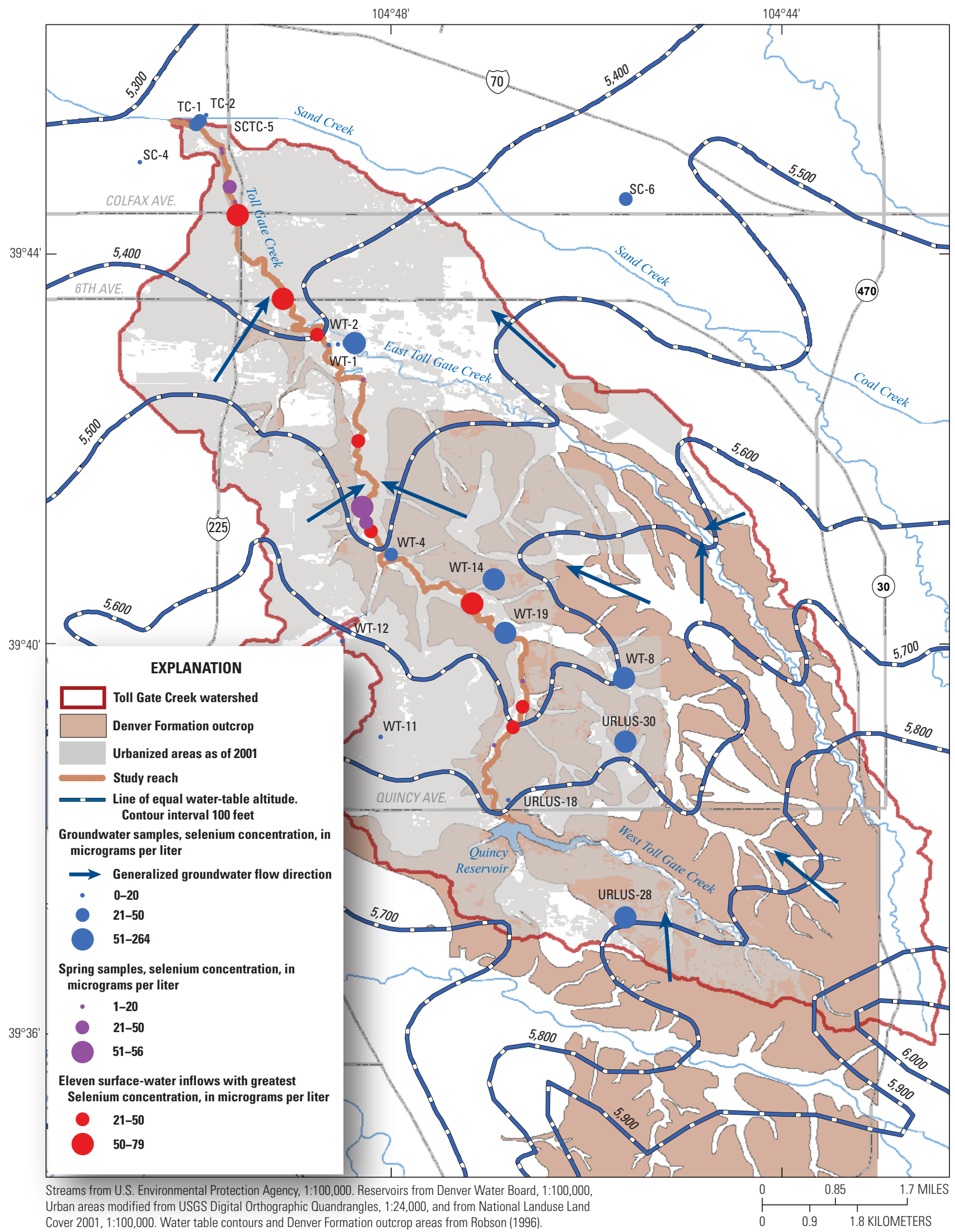

Figure 23. Map showing dissolved selenium concentrations in groundwater, springs, and the eleven inflows with the greatest selenium concentrations from synoptic sampling, Toll Gate Creek, July-August 2007. 
not adversely affected by the increased streamflow associated with rainfall during sampling of the TGM subreach. The smooth transition is attributable to the fact that the increased streamflow values (fig. 17) and diluted selenium concentrations (fig. 18) associated with the TGM subreach tend to balance each other within the load calculations. The loading analysis for the TGM subreach is thus consistent with the other subreaches despite the increased streamflow because the net effect of increased streamflow was dilution, a process that does not influence constituent load.

The loading results presented in figure 24 are subject to uncertainty because of the complicating factors discussed in the previous paragraph and in Appendix 1. Of particular concern are the estimates of streamflow that are used within equation 1 to calculate load. To evaluate the potential uncertainty in the loading analysis, selenium loads were recalculated using the alternative streamflow profiles developed in Appendix 1. The resultant loading profile is similar to that shown in figure 24, and thus provides assurance that Toll Gate Creek is subject to a steady increase in selenium loading under low-flow conditions.

\section{General Water-Quality Characteristics}

The underlying geology, the semiarid climate, and likely agricultural and urban development affect water quality in the Toll Gate Creek watershed, which is characterized by TDS concentrations that frequently exceeded the USEPA secondary drinking-water standard of $500 \mathrm{mg} / \mathrm{L}$ (U.S. Environmental Protection Agency, 2003), near-neutral to

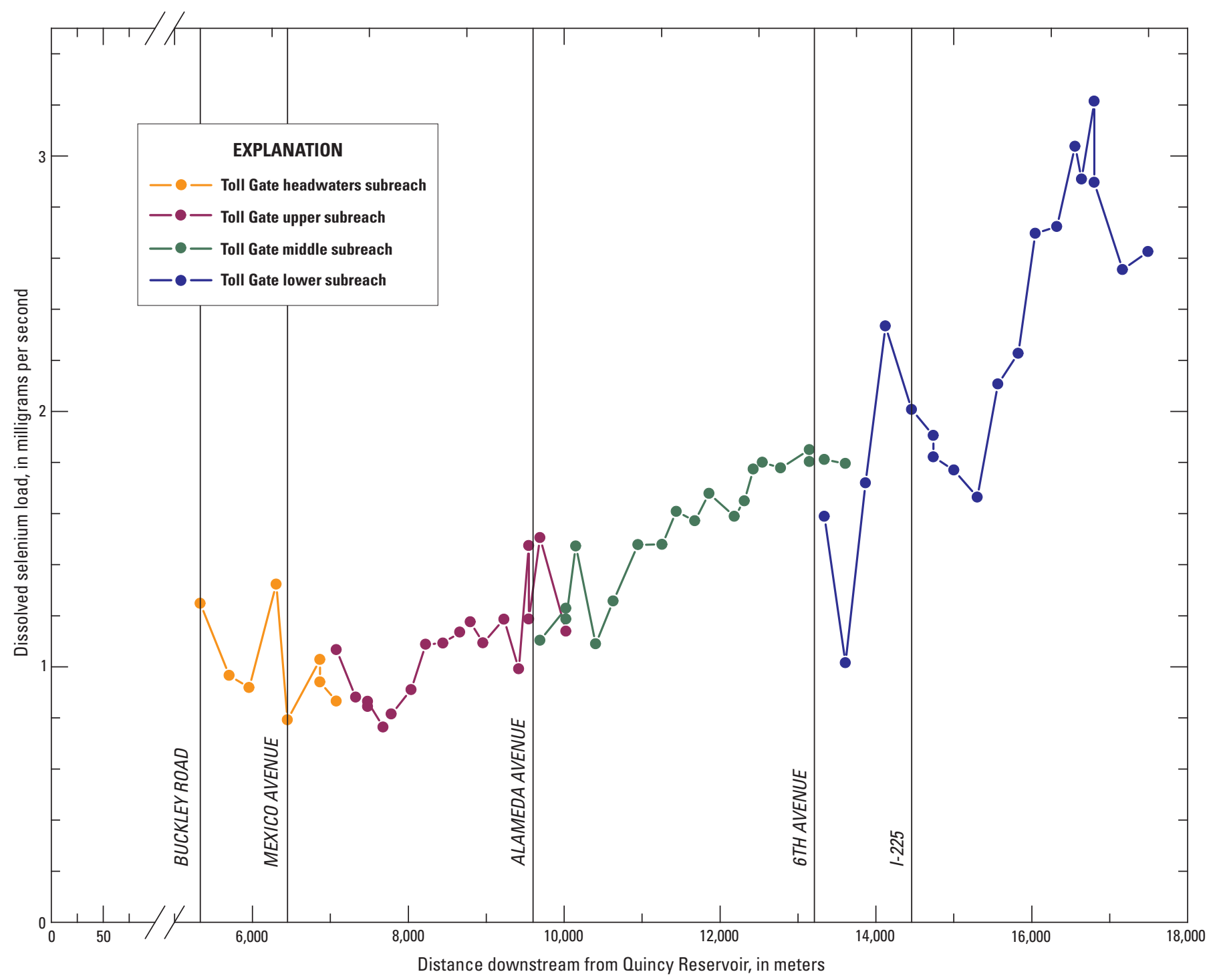

Figure 24. Graph showing dissolved selenium instream load in relation to distance downstream from Quincy Reservoir, Toll Gate Creek, July-August 2007. 
slightly alkaline $\mathrm{pH}$ values, a wide range of redox conditions, detections of nitrate in groundwater, hydrogen-oxygen isotope ratios indicative of active evaporative processes, and groundwater-age interpretations of primarily young water recharged since the 1960s.

\section{Total Dissolved Solids and Major-Ion Chemistry}

Concentrations of TDS ranged from 679 to $4,400 \mathrm{mg} / \mathrm{L}$ for groundwater samples, from 472 to $3,930 \mathrm{mg} / \mathrm{L}$ for inflow samples, and from 972 to $1,800 \mathrm{mg} / \mathrm{L}$ for stream samples (fig. 25). While the median TDS concentrations were similar among the groundwater, inflow, and stream samples $(1,540$, 1,520 , and $1,520 \mathrm{mg} / \mathrm{L}$, respectively), and frequently exceeded the USEPA secondary drinking-water standard of $500 \mathrm{mg} / \mathrm{L}$ (U.S. Environmental Protection Agency, 2003), TDS values for stream samples were less variable than for groundwater or inflow samples (fig. 25). The widespread occurrence of elevated TDS concentrations in groundwater, inflows, and stream samples indicates groundwater is interacting with and dissolving soluble minerals and salts from the surficial materials and claystone bedrock as it moves downgradient from recharge areas toward the discharge area of Toll Gate Creek. During precipitation events, present-day evaporative salts observed on streambanks are dissolved by rising streams and the water table, and are another source of increased selenium and TDS concentrations in Toll Gate Creek. The groundwater TDS concentration at a given location would depend on the occurrence and availability of soluble salts, $\mathrm{pH}$, redox conditions, and groundwater-residence time. Other processes that can increase TDS concentrations include evaporative concentration, irrigation return flows, or runoff and recharge from urban areas. The relatively small variability in TDS concentrations for stream samples indicates that hydrological, geochemical, and biological instream processes are effectively mixing the inflows and groundwater discharge received by the stream.

In order of decreasing abundance, major cations in water in the Toll Gate Creek watershed are calcium, magnesium, and sodium; major anions are sulfate, bicarbonate, and chloride; and the predominant water type is calcium sulfate (fig. 26). Similar to selenium and TDS, major-ion chemistry for groundwater and inflow samples was more variable than that for stream samples and ranged from calcium-carbonate to sodium-sulfate type water (fig. 26). Calcium-sulfate type

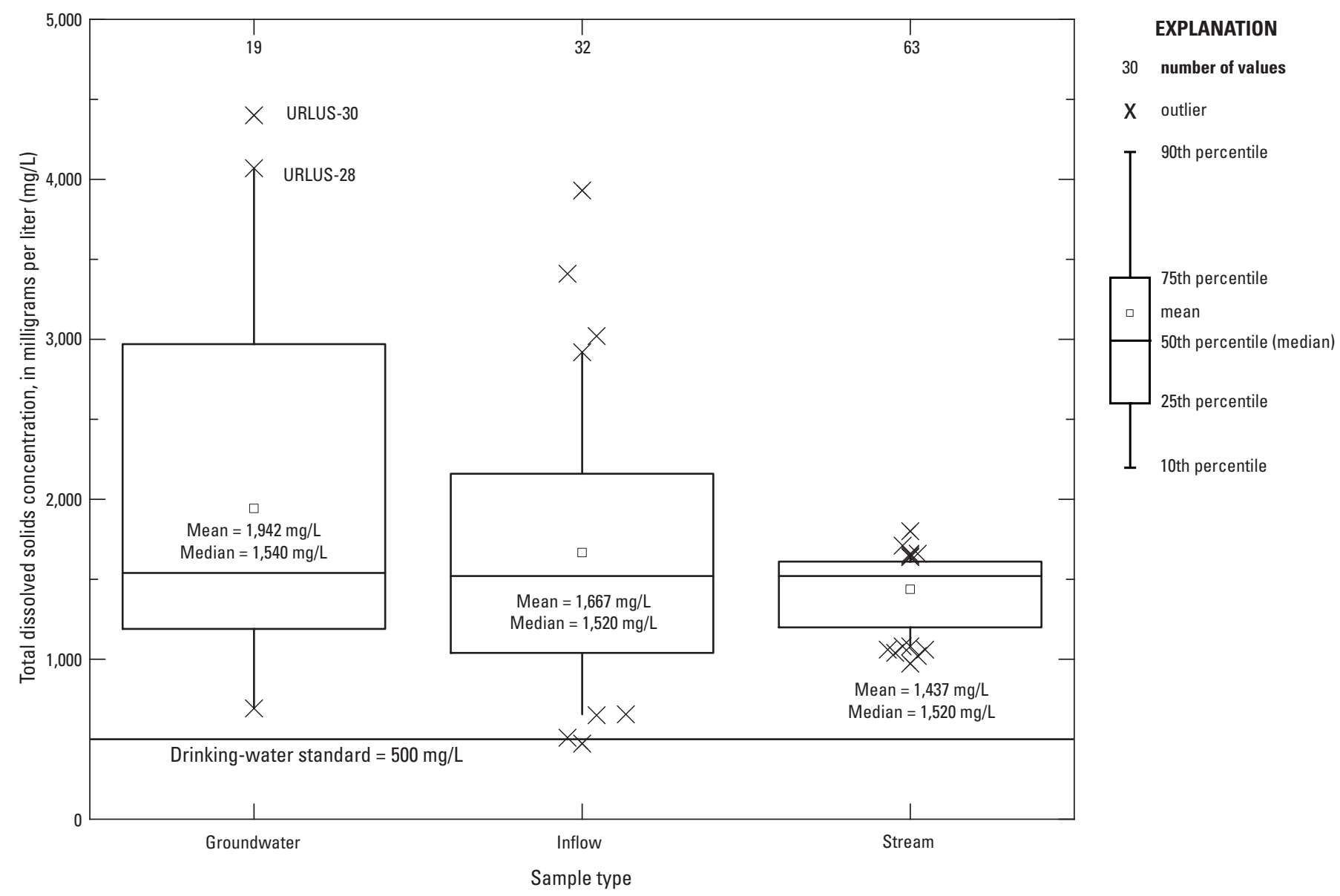

Figure 25. Boxplot showing distribution of total dissolved solids concentrations, in milligrams per liter, for groundwater, inflow, and stream samples, Toll Gate Creek, July-August 2007. Site names indicated for groundwater upper outliers. 
water was observed for the majority of groundwater and inflow samples and all of the stream samples. Calciumcarbonate type water was observed only in groundwater samples from wells WT-11 and WT-12, which are completed in surficial materials. Sodium-sulfate type water was observed for five inflows. Calcium-carbonate type water represents recharge and water-rock interaction with surficial materials that contain more carbonate minerals than the bedrock (Robson and Romero, 1981), whereas calcium-sulfate water type with increased selenium and TDS concentrations compared to calcium-carbonate-type waters represents water-rock interaction with claystone bedrock. Sodium-sulfate type water observed for inflow samples represents an increase in sodium cations as compared to calcium cations and could be caused by dissolution of sodium from bedrock, urban runoff, or exchange of calcium for sodium from the claystone bedrock. The preponderance of calcium-sulfate type water indicates that groundwater and surface water sampled by this study are affected by water-rock interaction with Denver Formation claystone bedrock.

\section{$\mathrm{pH}$}

Values of $\mathrm{pH}$ were near neutral for groundwater, near neutral to slightly alkaline for inflows, and slightly alkaline for stream samples (fig. 27). Groundwater $\mathrm{pH}$ ranged from 6.8 to 7.4 standard units with a median of 7.1. Inflow $\mathrm{pH}$ ranged from 6.9 to 9.0 with a median of 7.8 , and stream $\mathrm{pH}$ ranged

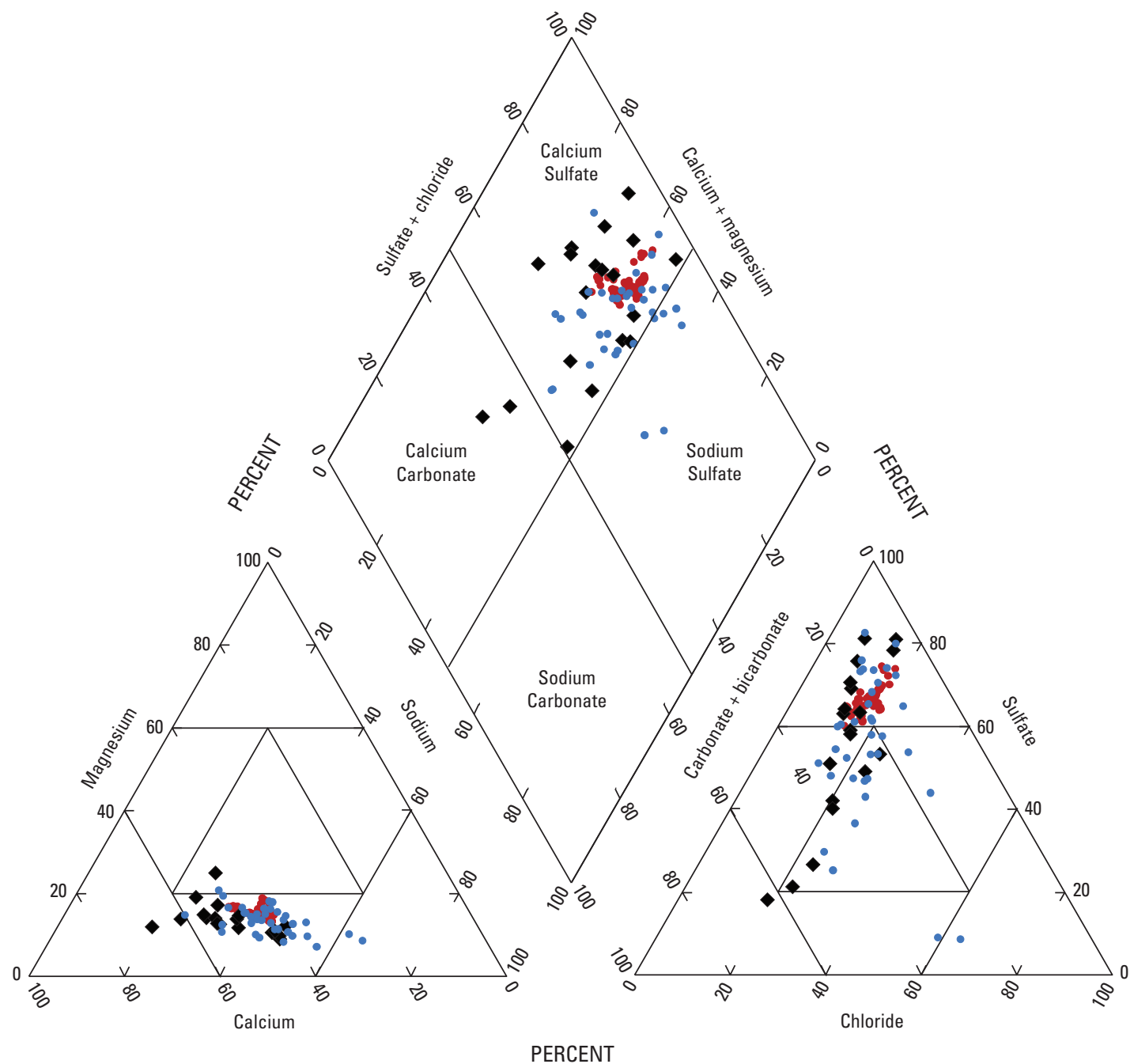

EXPLANATION

- Groundwater sample

- Inflow sample

- Stream sample

Figure 26. Trilinear plot showing percentages of major cations and anions, in milliequivalents per liter, for groundwater, inflow, and stream samples, Toll Gate Creek, July-August 2007. 
from 7.7 to 9.0 with a median of 8.2 standard units. Inflow and stream $\mathrm{pH}$ values were in general greater than and more variable than groundwater $\mathrm{pH}$ values indicating they are likely affected by biological processes that generate alkalinity such as biological respiration or plant activity. The $\mathrm{pH}$ values are in the range where oxidized forms of selenium (selenite and selenate) can adsorb onto bentonite clays ( $\mathrm{pH}$ values less than 7) and onto iron oxides (pH values between 5 and 8 ; McNeal and Balistrieri, 1989).

\section{Dissolved Oxygen}

The dissolved-oxygen (DO) concentration of water is an indicator of its reduction/oxidation potential or redox state, and is an important parameter to consider because chemical speciation and concentrations of other dissolved constituents, such as selenium, can depend on redox state. For example, selenium is mobile and toxic in the near-surface environment in the oxidized forms selenate $\left(\mathrm{SeO}_{4}{ }^{2-}\right)$ and selenite $\left(\mathrm{SeO}_{3}{ }^{2-}\right)$, and is less mobile in its reduced forms elemental selenium $\left(\mathrm{Se}^{\circ}\right)$ and selenide $\left(\mathrm{Se}^{2-}\right)$. Oxidized waters in equilibrium with atmospheric oxygen typically will have DO concentrations on the order of 5-10 $\mathrm{mg} / \mathrm{L}$, whereas low-oxygen waters that have undergone some reduction will typically have DO concentrations on the order of 0.5-2 mg/L (Rose and Long, 1988). Reduced waters generally exhibit DO concentrations less than $0.5 \mathrm{mg} / \mathrm{L}$ and may also contain other reduced chemical species such as nitrogen gas, methane, or hydrogen sulfide depending on the presence of electron acceptors (Rose and Long, 1988).

Low-oxygen concentrations in the presence of reduced chemical species can indicate mixed redox conditions and that the water is not in chemical equilibrium (White and others, 1990).

Groundwater samples for the Toll Gate Creek study exhibited DO concentrations ranging from $0.1 \mathrm{mg} / \mathrm{L}$ to $7.4 \mathrm{mg} / \mathrm{L}$ indicating a wide range of redox conditions in the groundwater system. The greatest DO concentrations representing oxidizing conditions $(7.4 \mathrm{mg} / \mathrm{L}$ and $3.5 \mathrm{mg} / \mathrm{L})$ occurred in water from wells SC-6 and SC-4, respectively, which are completed in the surficial materials along Sand Creek and outside of the Toll Gate Creek watershed. Water from 4 wells had low-oxygen DO concentrations ranging from 1.0 to $2.3 \mathrm{mg} / \mathrm{L}$, and water from the remaining 11 wells for which DO was measured indicated reducing conditions with DO concentrations of $0.6 \mathrm{mg} / \mathrm{L}$ or less. There was no

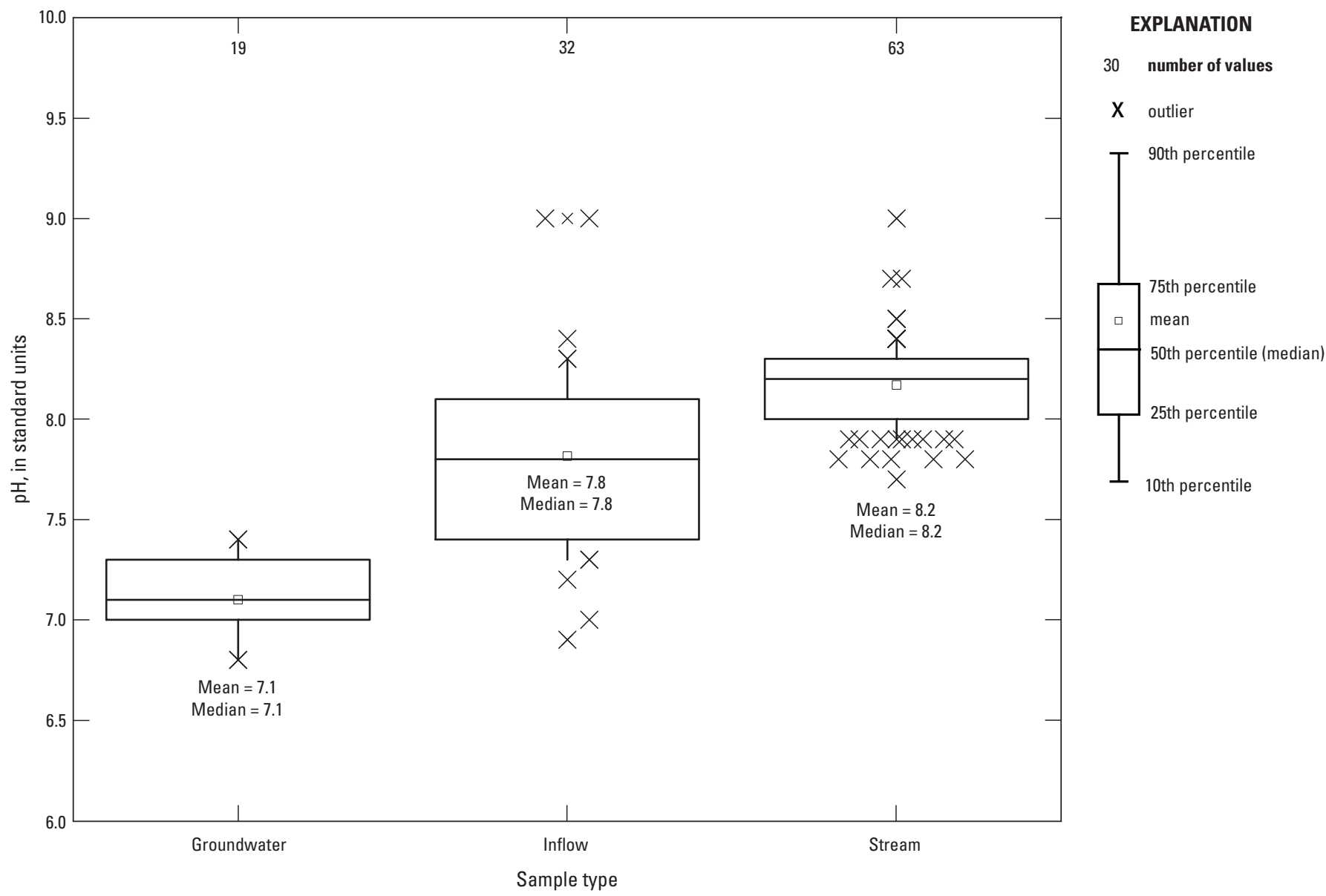

Figure 27. Boxplot showing distribution of pH values, in standard units, for groundwater, inflow, and stream samples, Toll Gate Creek, July-August 2007. 
clear spatial pattern to the groundwater DO concentrations, although all of the wells sampled within the Toll Gate Creek watershed indicated low-oxygen to reducing conditions, and there was no strong statistical correlation between DO and selenium concentrations determined by linear regression (Helsel and Hirsch 2002) (linear correlation coefficient $=0.17$ ) indicating that concentrations of selenium were not everywhere related to dissolved-oxygen concentrations and that mixed-redox conditions are possibly present in groundwater. Concentrations of DO were not measured for inflow or stream samples in contact with the atmosphere for this study. Oxidizing conditions would be expected in surface water when the stream flows over rapids and is well aerated, whereas low-oxygen or reducing conditions would be expected locally in streambed sediments or in wetland areas with abundant plant matter.

\section{Nitrate}

Dissolved nitrite plus nitrate as nitrogen, herein referred to as "nitrate," concentrations in groundwater ranged from less than $0.06 \mathrm{mg} / \mathrm{L}$ to a maximum of $18.6 \mathrm{mg} / \mathrm{L}$ at well URLUS-30 with a median concentration of $5.4 \mathrm{mg} / \mathrm{L}$ (table 6; fig. 28). Nitrate concentrations in groundwater were greater than the lowest surface-water concentration of $0.5 \mathrm{mg} / \mathrm{L}$ at 16 of the 19 wells and greater than the USEPA secondary drinking-water standard of $10 \mathrm{mg} / \mathrm{L}$ (U.S. Environmental Protection Agency, 2003) at 5 of the 19 wells (table 6). Dissolved-oxygen concentrations of $2 \mathrm{mg} / \mathrm{L}$ or less in the presence of nitrate were observed at those 5 wells and can be indicative of nitrate-reducing conditions (denitrification). (Peter McMahon, U.S. Geological Survey, written commun., 2011; White and others, 1990). Denitrification tends to reduce nitrate to nitrogen gas, decreasing nitrate concentrations and increasing nitrogen gas concentrations in groundwater (Knowles, 1982; Böhlke and others, 2007). The presence of excess nitrogen gas concentrations at wells MC-2B, WT-8, and WT-14 (see table 8) indicates denitrification was occurring, and the detection of low-oxygen concentrations in the presence of nitrogen gas indicates mixed-redox conditions were present at some locations in the groundwater system. Nitrate has been identified under laboratory conditions as an electron donor that can oxidize reduced forms of selenium during denitrification (Weres and others, 1990; White and Dubrovsky, 1994), and two of the greatest nitrate concentrations for Toll Gate Creek groundwater samples were observed for the two samples with the greatest selenium concentrations (URLUS-30 and URLUS-28). Possible sources of nitrate in the Toll Gate Creek watershed include atmospheric deposition, organic nitrogen from soils and bedrock, synthetic or manure fertilizers, leaking sewers or septic systems, or human or animal waste. Results from ongoing studies of selenium oxidation state and mobilization in western Colorado indicate that organic nitrogen can be released from organic-rich shale as nitrate (Alisa Mast, U.S. Geological Survey, oral commun., 2012). Synthetic or manure fertilizers and leaking sewers or septic systems are other possible sources of nitrate in the urbanized area of Toll Gate Creek. Analysis of the nitrogenand oxygen-isotope composition of dissolved nitrate could help identify and better understand nitrate sources in the study area.

Dissolved nitrate concentrations in inflow samples (median concentration of $2.9 \mathrm{mg} / \mathrm{L}$ ) were in general less than in groundwater samples (median concentration of $5.4 \mathrm{mg} / \mathrm{L}$; fig. 28) possibly because of dilution and (or) nitrate reduction along flow paths where groundwater is in contact with organic carbon in claystone and lignite. Similar to selenium, dissolved nitrate concentrations in stream samples (median concentration of $0.51 \mathrm{mg} / \mathrm{L}$; fig. 28) were less than and less variable than in groundwater or inflow samples. Nitrate concentrations in surface water are likely attenuated by plant uptake as evidenced by large algal blooms and abundant aquatic macrophytes noted during field activities.

\section{Correlations Among Chemical Constituents}

Stream concentrations of dissolved selenium exhibit positive correlation with concentrations of TDS and dissolved sodium, sulfate, uranium, chloride, and nitrate in Toll Gate Creek (table 9). Because most of these constituents are derived from weathering of underlying bedrock and transported to the stream by the same processes as dissolved selenium, streamprofiles for concentrations and loads of sodium, sulfate, and uranium (Appendix 3) are similar to those for selenium and exhibit increases in load in a downstream direction (figs. 3-1 to 3-6). In groundwater, dissolved selenium concentrations are strongly correlated with concentrations of TDS and dissolved calcium, magnesium, sodium, sulfate, chloride, bromide, nitrate, organic carbon and oxygen-isotope ratios (table 10). Strong correlations among dissolved constituents indicate that the constituents may be derived from the same or related geologic sources.

\section{Multivariate Analysis of Water Chemistry}

Multivariate cluster analysis was applied to data for waterquality samples to recognize patterns or chemical characteristics among samples that can help identify the various sources of constituents (Kauffman and Rousseeuw, 1990). Data for inflow, groundwater, and stream samples were analyzed separately because different sets of variables were used for each. 
Table 8. Tritium, dissolved-gas, and chlorofluorocarbon concentrations, apparent groundwater ages, and apparent recharge rates for selected groundwater samples, Toll Gate Creek, July-August 2007.

[DO, dissolved oxygen; TU, tritium units; mg/L, milligrams per liter; ${ }^{\circ} \mathrm{C}$, degrees Celsius; $\mathrm{CFC}$, chlorofluorocarbon; pmol/kg, picomoles per kilogram; pptv, parts per trillion by volume; nd, no data; na, not applicable; in/yr, inches per year; pfm, piston-flow model; bmm, binary-mixing model; $\mathrm{N}_{2}$, nitrogen gas; $\mathrm{CH}_{4}$, methane gas; OF, old fraction; YF, young fraction]

\begin{tabular}{|c|c|c|c|c|c|c|c|c|c|c|c|c|}
\hline \multirow{2}{*}{$\begin{array}{l}\text { Well } \\
\text { name }\end{array}$} & \multirow{2}{*}{$\begin{array}{l}\text { Geologic materials of } \\
\text { screened interval }\end{array}$} & \multirow{2}{*}{$\begin{array}{l}\text { Tritium } \\
\text { (TU) }\end{array}$} & \multirow{2}{*}{$\begin{array}{c}\mathrm{DO} \\
(\mathrm{mg} / \mathrm{L})\end{array}$} & \multirow{2}{*}{$\begin{array}{l}\text { Excess } N_{2^{\prime}} \\
(\mathrm{mg} / \mathrm{L})\end{array}$} & \multirow{2}{*}{$\begin{array}{l}\text { Methane } \\
\text { (mg/L) }\end{array}$} & \multirow{2}{*}{$\begin{array}{c}\text { Recharge } \\
\text { temperature } \\
\left({ }^{\circ} \mathrm{C}\right)\end{array}$} & \multicolumn{3}{|c|}{$\begin{array}{c}\text { Corrected CFC concentration in } \\
\text { solution (pmol/kg) }\end{array}$} & \multicolumn{3}{|c|}{$\begin{array}{l}\text { Calculated CFC atmospheric mixing } \\
\text { ratio (pptv) }\end{array}$} \\
\hline & & & & & & & CFC-12 & CFC-11 & CFC-13 & CFC-12 & CFC-11 & CFC-13 \\
\hline ET-1 & Alluvium & 6.8 & 0.1 & 0.0 & 0.0 & 15.2 & 3.67 & 1.33 & 0.11 & 1022.3 & 102.8 & 27.6 \\
\hline ET-2 & Alluvium & 8.6 & 0.2 & 0.0 & 0.0 & 11.9 & 3.86 & 4.14 & 0.33 & 962.4 & 273.3 & 71.3 \\
\hline MC-2B & Alluvium & 10.9 & 0.1 & 1.0 & 0.062 & 13.2 & 1.27 & 0.03 & 0.02 & 330.0 & 2.1 & 3.4 \\
\hline SC-6 & Alluvium & 15.0 & 7.4 & 0.0 & 0.0 & 12.1 & 3.05 & 4.17 & 0.33 & 773.7 & 280.3 & 72.7 \\
\hline SCTC-5 & Alluvium & 9.5 & 0.2 & 0.0 & 0.254 & 15.9 & 0.68 & 0.05 & 0.02 & 198.7 & 3.9 & 4.0 \\
\hline URLUS-18 & Alluvium & 7.5 & nd & 0.0 & 0.0 & 17.7 & 1.25 & 2.29 & 0.15 & 362.7 & 186.8 & 38.8 \\
\hline URLUS-28 & $\begin{array}{l}\text { Alluvium/Denver } \\
\text { Claystone }\end{array}$ & 2.6 & 2.3 & 0.0 & 0.0 & 5.2 & 2.02 & 2.45 & 0.20 & 360.9 & 113.9 & 28.6 \\
\hline URLUS-30 & Denver claystone & 2.5 & 2.0 & 0.0 & 0.0 & 12.9 & 2.50 & 3.61 & 0.39 & 646.4 & 259.1 & 89.3 \\
\hline WT-1 & $\begin{array}{l}\text { Alluvium/Denver } \\
\text { sandstone }\end{array}$ & 12.3 & 1.8 & 0.0 & 0.0 & 11.5 & 1.98 & 1.62 & 0.18 & 483.8 & 105.4 & 37.0 \\
\hline WT-12 & Alluvium & nd & 0.1 & 0.0 & 0.0 & 13.6 & 2.25 & 0.18 & 0.03 & 596.9 & 13.2 & 6.3 \\
\hline WT-14 & Alluvium & 8.7 & 1.0 & 2.0 & 0.016 & 28.0 & 0.90 & 0.29 & 0.04 & 417.7 & 40.0 & 17.3 \\
\hline WT-19 & Alluvium & 8.2 & nd & 0.0 & 0.0 & 15.5 & 2.32 & 0.19 & 0.02 & 665.8 & 15.5 & 5.6 \\
\hline WT-4 & Alluvium & 8.6 & 0.1 & 0.0 & 0.0 & 15.0 & 1.10 & 0.29 & 0.01 & 315.7 & 22.8 & 2.9 \\
\hline WT-8 & Alluvium & 5.4 & 0.1 & 3.0 & 0.0 & 12.3 & 17.19 & 0.09 & 0.02 & 4257.0 & 6.4 & 3.4 \\
\hline
\end{tabular}


Table 8. Tritium, dissolved-gas, and chlorofluorocarbon concentrations, apparent groundwater ages, and apparent recharge rates for selected groundwater samples, Toll

Gate Creek, July-August 2007.-Continued

[DO, dissolved oxygen; TU, tritium units; mg/L, milligrams per liter; ${ }^{\circ} \mathrm{C}$, degrees Celsius; $\mathrm{CFC}$, chlorofluorocarbon; pmol/kg, picomoles per kilogram; pptv, parts per trillion by volume; nd, no data; na, not applicable; in/yr, inches per year; pfm, piston-flow model; bmm, binary-mixing model; $\mathrm{N}_{2}$, nitrogen gas; $\mathrm{CH}_{4}$, methane gas; OF, old fraction; YF, young fraction]

\begin{tabular}{|c|c|c|c|c|c|c|c|c|c|}
\hline $\begin{array}{l}\text { Well } \\
\text { name }\end{array}$ & $\begin{array}{c}\text { CFC } \\
\text { piston-flow } \\
\text { model apparent } \\
\text { recharge age } \\
\text { (years) }\end{array}$ & $\begin{array}{c}\text { CFC } \\
\text { piston-flow } \\
\text { model apparent } \\
\text { recharge year }\end{array}$ & $\begin{array}{c}\text { Tritium } \\
\text { piston-flow } \\
\text { model apparent } \\
\text { recharge year }\end{array}$ & $\begin{array}{l}\text { Binary-mixing } \\
\text { model apparent } \\
\text { recharge year } \\
\text { of young-water } \\
\text { fraction }\end{array}$ & $\begin{array}{c}\text { Binary-mixing } \\
\text { model } \\
\text { young-water } \\
\text { fraction } \\
\text { (percent) }\end{array}$ & $\begin{array}{l}\text { Depth to top } \\
\text { of screened } \\
\text { interval below } \\
\text { land surface } \\
\text { (feet) }\end{array}$ & $\begin{array}{l}\text { Depth to top } \\
\text { of screened } \\
\text { interval below } \\
\text { water table } \\
\text { (feet) }\end{array}$ & $\begin{array}{l}\text { Estimated } \\
\text { piston-flow } \\
\text { recharge } \\
\text { rate (in/yr) }\end{array}$ & $\begin{array}{l}\text { Comments and basis } \\
\text { for piston-flow model (pfm) } \\
\text { apparent age }\end{array}$ \\
\hline
\end{tabular}

$\begin{array}{lllllllll}\text { ET-1 } & 25-34 & 1974-1983 & 1982 & 1989 & 40-50 & 14.0 & 1.9 & 0.7-0.9\end{array}$
CFC-11 and CFC-113 degradation; pfm age on the basis of CFC-11, CFC113, and tritium; possible mixture, bmm results on the basis of CFC-113/CFC-11 ratio; DO concentration indicates reducing conditions.

7.0

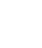

(1)

CFC-12 contaminated; pfm age on the basis of CFC-11, CFC-113, and tritium; DO concentration indicates reducing conditions.

0.5 CFC-11 and CFC-113 degraded; pfm age on the basis of CFC-12 and tritium; DO concentration indicates reducing conditions; excess N2 indicates denitrification; $\mathrm{CH} 4$ indicates methanogenesis. the basis of CFC-113 and tritium.

1.9 CFC-11 and CFC-113 degraded; pfm age on the basis of CFC-12 and tritium; DO concentration indicates reducing conditions; $\mathrm{CH} 4$ indicates methanogenesis.

1.6 CFC-12 contaminated; pfm age on the basis of CFC-11, CFC-113, and tritium.

0.7 OF CFC-11 degraded; pfm age on the basis of CFC-12 and CFC-113; bmm results on the basis of CFC113/CFC-11 ratio and tritium. 
Table 8. Tritium, dissolved-gas, and chlorofluorocarbon concentrations, apparent groundwater ages, and apparent recharge rates for selected groundwater samples, Toll Gate Creek, July-August 2007.-Continued

[DO, dissolved oxygen; TU, tritium units; mg/L, milligrams per liter; ${ }^{\circ} \mathrm{C}$, degrees Celsius; $\mathrm{CFC}$, chlorofluorocarbon; pmol/kg, picomoles per kilogram; pptv, parts per trillion by volume; nd, no data; na, not applicable; in/yr, inches per year; pfm, piston-flow model; bmm, binary-mixing model; $\mathrm{N}_{2}$, nitrogen gas; $\mathrm{CH}_{4}$, methane gas; OF, old fraction; YF, young fraction]

\begin{tabular}{|c|c|c|c|c|c|c|c|c|c|}
\hline $\begin{array}{l}\text { Well } \\
\text { name }\end{array}$ & $\begin{array}{c}\text { CFC } \\
\text { piston-flow } \\
\text { model apparent } \\
\text { recharge age } \\
\text { (years) }\end{array}$ & $\begin{array}{c}\text { CFC } \\
\text { piston-flow } \\
\text { model apparent } \\
\text { recharge year }\end{array}$ & $\begin{array}{l}\text { Tritium } \\
\text { piston-flow } \\
\text { model apparent } \\
\text { recharge year }\end{array}$ & $\begin{array}{l}\text { Binary-mixing } \\
\text { model apparent } \\
\text { recharge year } \\
\text { of young-water } \\
\text { fraction }\end{array}$ & $\begin{array}{l}\text { Binary-mixing } \\
\text { model } \\
\text { young-water } \\
\text { fraction } \\
\text { (percent) }\end{array}$ & $\begin{array}{l}\text { Depth to top } \\
\text { of screened } \\
\text { interval below } \\
\text { land surface } \\
\text { (feet) }\end{array}$ & $\begin{array}{l}\text { Depth to top } \\
\text { of screened } \\
\text { interval below } \\
\text { water table } \\
\text { (feet) }\end{array}$ & $\begin{array}{l}\text { Estimated } \\
\text { piston-flow } \\
\text { recharge } \\
\text { rate }(\mathrm{in} / \mathrm{yr})\end{array}$ & $\begin{array}{l}\text { Comments and basis } \\
\text { for piston-flow model (pfm) } \\
\text { apparent age }\end{array}$ \\
\hline URLUS-30 & $11-12$ & 1996-1997 & pre-1953 & 1996 & 95 & 28.0 & 13.0 & $\begin{array}{l}1.0 \mathrm{OF} \\
4.4-4.8 \\
\mathrm{YF}\end{array}$ & $\begin{array}{l}\text { CFC-12 contaminated; pfm age on } \\
\text { the basis of CFC-113; possible } \\
\text { mixture; bmm results on the basis } \\
\text { of CFC-11, CFC-113, and tritium. }\end{array}$ \\
\hline WT-1 & $18-19$ & 1988-1989 & 1989 & na & na & 10.0 & 3.5 & 1.4 & $\begin{array}{l}\text { CFC-11 degraded; pfm age on basis } \\
\text { of CFC- } 12 \text { and tritium. }\end{array}$ \\
\hline WT-12 & $37-42$ & 1966-1971 & nd & na & na & 25.0 & 16.8 & $1.7-2.0$ & $\begin{array}{l}\text { CFC-12 contaminated; pfm age on } \\
\text { the basis of CFC-113; no tritium } \\
\text { analysis; DO concentration indi- } \\
\text { cates reducing conditions. }\end{array}$ \\
\hline WT-14 & 22 & 1986 & 1986 & na & na & 8.0 & 2.9 & 0.8 & $\begin{array}{l}\text { CFC-11 and CFC-113 degraded; ex- } \\
\text { cess N2 indicates denitrification; } \\
\text { CH4 indicates methanogenesis; } \\
\text { pfm age on the basis of CFC-12 } \\
\text { and tritium. }\end{array}$ \\
\hline WT-19 & 45 & 1962 & $\begin{array}{l}1961 \text { or early } \\
1980 \mathrm{~s}\end{array}$ & na & na & 16.0 & 8.4 & $0.9-1.6$ & $\begin{array}{l}\text { CFC- } 12 \text { contaminated; pfm age on } \\
\text { the basis of CFC-11 and tritium. }\end{array}$ \\
\hline WT-4 & 28 & 1980 & 1980 & na & na & 22.0 & 17.3 & 2.4 & $\begin{array}{l}\text { CFC-11 and CFC- } 113 \text { degraded; } \\
\text { pfm age on the basis of CFC-12 } \\
\text { and tritium; DO concentration } \\
\text { indicates reducing conditions. }\end{array}$ \\
\hline WT-8 & na & na & na & na & na & na & na & na & $\begin{array}{l}\text { Cannot date; CFC-12 contaminated; } \\
\text { CFC-11 and CFC-113 degraded; } \\
\text { DO concentration indicates } \\
\text { reducing conditions; excess N2 } \\
\text { indicates denitrification. }\end{array}$ \\
\hline
\end{tabular}




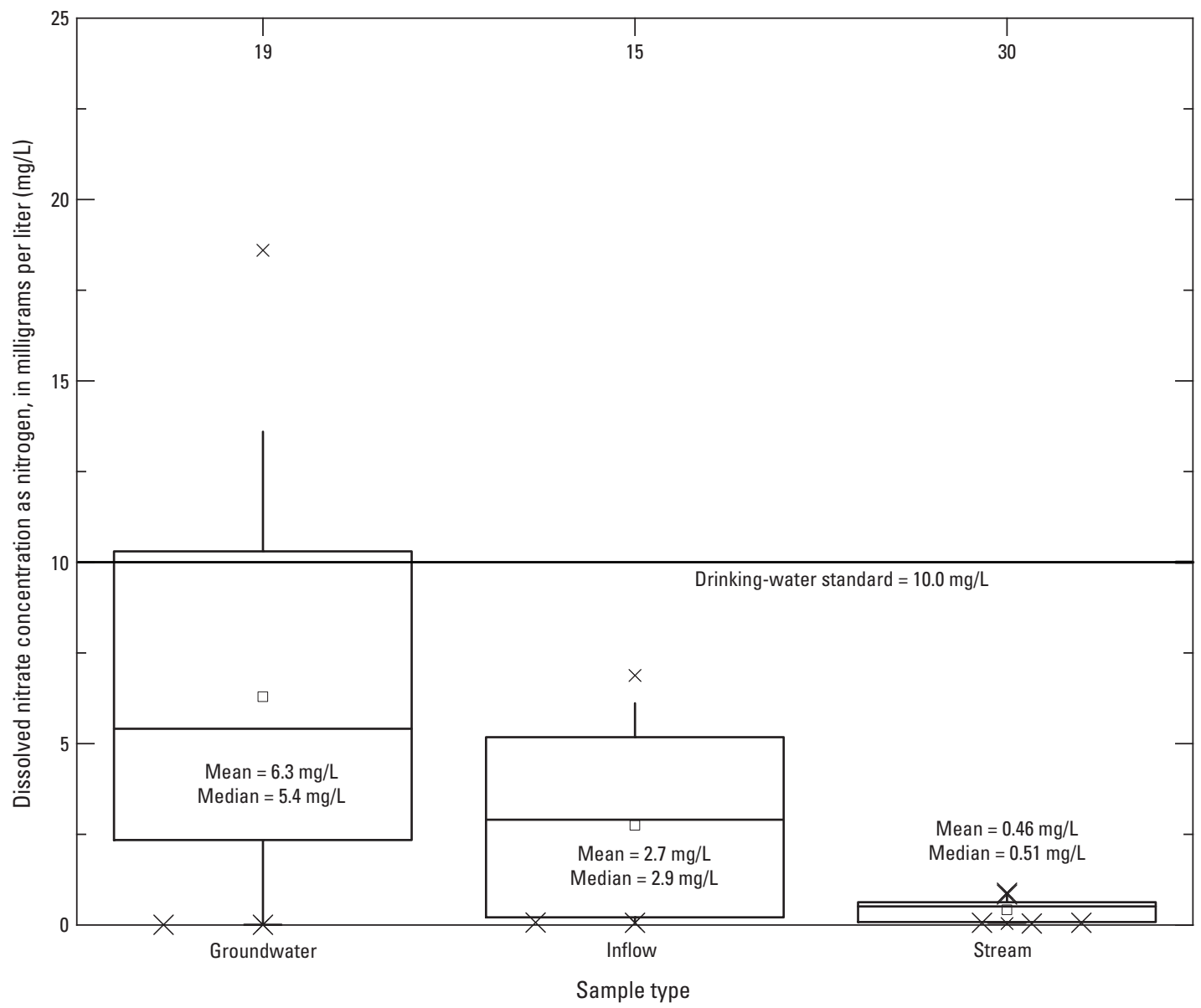

EXPLANATION

30 number of values

X outlier

T 90th percentile

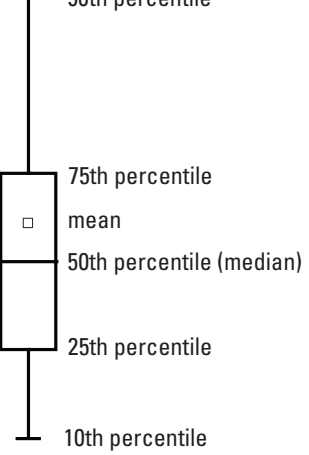

Reporting level $=0.06 \mathrm{mg} / \mathrm{L}$

Figure 28. Boxplot showing distribution of dissolved nitrate (nitrite plus nitrate) concentrations as nitrogen, in milligrams per liter, in groundwater, inflow, and stream samples, Toll Gate Creek, Colorado, July-August 2007. 
Table 9. Linear correlation coefficients for dissolved constituents in stream samples, Toll Gate Creek, July-August 2007.

[All constituents are dissolved except $\delta^{18} \mathrm{O}$; TDS, total dissolved solids; $\delta^{18} \mathrm{O}$, stable isotope ratio of oxygen $\left({ }^{18} \mathrm{O}\right.$ and $\left.{ }^{16} \mathrm{O}\right)$ relative to Vienna Standard Mean Ocean Water; gray shading, linear correlation coefficient of about 0.60 or greater]

\begin{tabular}{|c|c|c|c|c|c|c|c|c|c|c|c|}
\hline Constituent & TDS & Calcium & Magnesium & Sodium & Selenium & Uranium & Sulfate & Alkalinity & Chloride & Bromide & Nitrate \\
\hline TDS & 1 & & & & & & & & & & \\
\hline Calcium & 0.90 & 1 & & & & & & & & & \\
\hline Magnesium & 0.88 & 0.83 & 1 & & & & & & & & \\
\hline Sodium & 0.89 & 0.76 & 0.64 & 1 & & & & & & & \\
\hline Selenium & 0.64 & 0.50 & 0.37 & 0.78 & 1 & & & & & & \\
\hline Uranium & 0.73 & 0.81 & 0.70 & 0.58 & 0.32 & 1 & & & & & \\
\hline Sulfate & 0.97 & 0.84 & 0.83 & 0.90 & 0.69 & 0.70 & 1 & & & & \\
\hline Alkalinity & 0.25 & 0.53 & 0.30 & 0.03 & -0.13 & 0.47 & 0.05 & 1 & & & \\
\hline Chloride & 0.85 & 0.66 & 0.61 & 0.95 & 0.72 & 0.45 & 0.84 & -0.03 & 1 & & \\
\hline Bromide & 0.39 & 0.21 & 0.12 & 0.57 & 0.47 & 0.14 & 0.34 & 0.03 & 0.61 & 1 & \\
\hline Nitrate & 0.33 & 0.29 & 0.08 & 0.50 & 0.85 & 0.09 & 0.33 & 0.01 & 0.44 & 0.39 & 1 \\
\hline$\delta^{18} 0$ & -0.10 & -0.24 & -0.38 & 0.26 & 0.36 & -0.21 & 0.03 & -0.56 & 0.20 & 0.33 & 0.31 \\
\hline
\end{tabular}

Table 10. Linear correlation coefficients for dissolved constituents in groundwater samples, Toll Gate Creek, July-August 2007.

[All constituents are dissolved except $\delta^{18} \mathrm{O}$; TDS, total dissolved solids; $\delta^{18} \mathrm{O}$, stable isotope ratio of oxygen $\left({ }^{18} \mathrm{O}\right.$ and $\left.{ }^{16} \mathrm{O}\right)$ relative to Vienna Standard Mean Ocean Water; DOC, dissolved organic carbon; gray shading, linear correlation coefficient of about 0.60 or greater]

\begin{tabular}{|c|c|c|c|c|c|c|c|c|c|c|c|c|}
\hline Constituent & TDS & Calcium & Magnesium & Sodium & Selenium & Uranium & Sulfate & Alkalinity & Chloride & Bromide & Nitrate & $\delta^{18} 0$ \\
\hline TDS & 1 & & & & & & & & & & & \\
\hline Calcium & 0.96 & 1 & & & & & & & & & & \\
\hline Magnesium & 0.95 & 0.95 & 1 & & & & & & & & & \\
\hline Sodium & 0.90 & 0.78 & 0.78 & 1 & & & & & & & & \\
\hline Selenium & 0.80 & 0.66 & 0.68 & 0.78 & 1 & & & & & & & \\
\hline Uranium & 0.32 & 0.40 & 0.36 & 0.39 & -0.09 & 1 & & & & & & \\
\hline Sulfate & 0.99 & 0.96 & 0.94 & 0.90 & 0.78 & 0.32 & 1 & & & & & \\
\hline Alkalinity & -0.24 & -0.11 & -0.11 & -0.18 & -0.53 & 0.67 & -0.27 & 1 & & & & \\
\hline Chloride & 0.76 & 0.70 & 0.66 & 0.69 & 0.75 & 0.09 & 0.70 & -0.23 & 1 & & & \\
\hline Bromide & 0.85 & 0.76 & 0.75 & 0.77 & 0.94 & -0.01 & 0.82 & -0.44 & 0.90 & 1 & & \\
\hline Nitrate & 0.53 & 0.42 & 0.44 & 0.65 & 0.68 & 0.21 & 0.53 & -0.16 & 0.47 & 0.63 & 1 & \\
\hline$\delta^{18} 0$ & 0.58 & 0.40 & 0.47 & 0.65 & 0.77 & -0.07 & 0.56 & -0.40 & 0.56 & 0.70 & 0.51 & 1 \\
\hline $\mathrm{DOC}$ & 0.82 & 0.74 & 0.70 & 0.79 & 0.85 & 0.17 & 0.79 & -0.26 & 0.76 & 0.90 & 0.61 & 0.73 \\
\hline
\end{tabular}




\section{Inflow and Groundwater Samples}

Chemical distinctions among groups of inflows are helpful to understand the various types of water that affect the stream chemistry. Four groups of inflow samples were distinguished from the cluster analysis, and representative samples from each group are listed in the order of increasing selenium concentration in table 11 . The groups are distinguished mostly by variation in the concentrations of selenium, calcium, magnesium, sodium, sulfate, bromide, and uranium. This grouping of constituents represents the first principal component and accounts for the majority of variation among inflow samples; the grouping also includes the constituents that have the most effect on stream chemistry. Samples from inflow group 1 generally have the lowest selenium and sulfate concentrations (table 11, fig. 29) whereas samples from inflow group 4 have the greatest concentrations of both constituents. It is notable that samples from inflow group 4 having the greatest selenium concentrations are distributed throughout the length of the Toll Gate Creek study as are samples from inflow groups 2 and 3 that generally have lesser selenium and sulfate concentrations (table 11, fig. 29).

The particular grouping of constituents prominent in samples of inflow water gives an important indication of the source of solutes affecting the stream (fig. 30). Groundwater groups also are plotted for comparison. Although the cluster analyses were constructed separately on samples from wells and samples of inflows, the clusters of samples from both analyses were principally distinguished by variations among concentrations of selenium, calcium, sodium, sulfate, bromide, and uranium. Four inflow groups and five groups of groundwater samples were distinguished in the cluster analysis. Among the groundwater samples, the groups had increasingly greater concentrations of constituents, similar to the concentrations shown in table 11 for the inflow samples. However, the groundwater sample for URLUS-30 was distinguished as a separate, additional group because that sample had much greater concentrations of several constituents than samples in the other groups. So using inflow and groundwater samples together, the covariation of sulfate with sodium (fig. 30A), bromide (fig. 30B), selenium (fig. 30C), and uranium (fig. 30D) is a likely result of a common geologic source for these constituents. The majority of inflow samples that have relatively greater concentrations of sodium and sulfate (inflow groups 2, 3, and 4; table 11) plot along a line that indicates a constant ratio between the solutes (fig. 30A). This pattern is consistent with having a common source of the solutes, and in those samples having sulfate concentrations greater than $300 \mathrm{mg} / \mathrm{L}$, the inflow groups represent progressively greater concentrations of both selenium and sulfate. Also, concentrations of the solutes in groundwater samples generally "surround" those of the inflows, which is consistent with the explanation that the chemistry of the high-selenium inflows relates to the chemistry of the groundwater. Thus, the distinction of the various inflow groups is likely a matter of progressive addition of the solutes through water-rock interaction. This relation of inflow to groundwater samples, in general, holds true for all the solutes in figure 30 . These results support the hypothesis that dissolved selenium, calcium, sodium, sulfate, bromide, and uranium are derived from the same geologic sources in the study area.

If the extent of water-rock interaction is a key to the concentrations of these solutes for particular inflows, then the groups could represent the size of drainage area contributing to the inflows, or local variations in bedrock mineralogy, or groundwater-residence time. Most of the samples from inflow group 4 come from culverts draining surface water and groundwater along the study reach. Although the extent of urbanization obscures the delineation of drainage areas, it is likely that these samples represent previous tributary areas that essentially collect more water that has flowed through the contributing geologic materials, causing the greater concentrations. Alternatively, the distinctions could be related to local variations in the mineralogy of the Denver Formation and the inflow samples that have the greatest concentrations of selenium, sulfate, and uranium could be from areas that contain more of the minerals being dissolved to contribute these solutes. Longer groundwater-residence times, caused by variable saturated thickness, perched water-table conditions, low-permeability materials, and low recharge rates, allow more time for water-rock interactions and provide yet another explanation for the variation in concentrations between groups. Finally, a combination of drainage area, mineralogy, and groundwater-residence time could be affecting constituent concentrations.

\section{Stream Samples}

Chemical differences among stream samples along a study reach typically indicate the principal sources and transformations of solutes along the study reach. If a study reach has been divided into a sequence of tracer-injection subreaches, as with the Toll Gate Creek study, any chemical differences among subreaches likely are a result of these sources and transformations and not a result of the operational details or changing weather conditions during the different injections. For Toll Gate Creek, samples from the different injection subreaches were affected by rain storms, and thus, the effects of solute sources and processes are difficult to interpret.

Samples of stream water in Toll Gate Creek were separated into five groups defined by cluster analysis. The representative chemistry of samples in each group is given in table 12. The effects of rain on these groups varied. Stream groups 1 and 2 include samples from the headwater sample subreach (TGH) and were the least affected by rain. In addition, these samples have lesser selenium concentrations than downstream samples (fig. 18, table 12) which causes them to fall below the line defined by stream group 3 through 5 samples in figure 31. Samples from stream group 3 (mostly from the TGU subreach) and stream group 5 (all from the TGL subreach) were affected by rain and both were sampled as streamflow decreased after storms (fig. 15). Samples from stream group 4 (TGM subreach) were most affected by 
Table 11. Representative samples from each of the inflow groups defined by cluster analysis, Toll Gate Creek, July-August 2007.

[mg/L, milligrams per liter; $\mathrm{CaCO}_{3}$, calcium carbonate; $\mathrm{SiO}_{2}$, silica; $\mu \mathrm{g} / \mathrm{L}$, micrograms per liter]

\begin{tabular}{|c|c|c|c|c|}
\hline \multirow[b]{2}{*}{ Constituent } & \multicolumn{4}{|c|}{ Group } \\
\hline & $\begin{array}{c}1 \\
\begin{array}{c}\text { Lowest concentrations of } \\
\text { sulfate and selenium }\end{array} \\
\end{array}$ & $\begin{array}{c}2 \\
\text { High manganese, } \\
\text { moderate selenium }\end{array}$ & $\begin{array}{c}3 \\
\text { High alkalinity, } \\
\text { moderate selenium }\end{array}$ & $\begin{array}{c}4 \\
\text { High selenium } \\
\text { and sulfate } \\
\end{array}$ \\
\hline Distance, meters & 9,417 & 12,323 & 16,576 & 8,809 \\
\hline Number of samples & 5 & 11 & 7 & 9 \\
\hline $\mathrm{pH}$, standard units & 7.8 & 8.1 & 6.9 & 8.2 \\
\hline Calcium, filtered, $\mathrm{mg} / \mathrm{L}$ & 94 & 174 & 292 & 298 \\
\hline Magnesium, filtered, mg/L & 21.7 & 30.7 & 32.8 & 45.4 \\
\hline Sodium, filtered, mg/L & 70.1 & 194 & 319 & 377 \\
\hline Alkalinity as $\mathrm{CaCO}_{3}, \mathrm{mg} / \mathrm{L}$ & 175 & 190 & 446 & 288 \\
\hline Sulfate, filtered, mg/L & 172 & 550 & 609 & 1,270 \\
\hline Chloride, filtered, mg/L & 102 & 172 & 295 & 151 \\
\hline Fluoride, filtered, mg/L & 1.1 & .67 & .54 & 1.0 \\
\hline Bromide, filtered, mg/L & .19 & .85 & 1.08 & .73 \\
\hline Silica as $\mathrm{SiO}_{2}$, filtered, $\mathrm{mg} / \mathrm{L}$ & 19.7 & 17.1 & 37.5 & 18.4 \\
\hline Aluminum, filtered, $\mu \mathrm{g} / \mathrm{L}$ & 12.5 & 14.5 & 69.3 & 8.0 \\
\hline Iron, filtered, $\mu \mathrm{g} / \mathrm{L}$ & 61 & 41 & 4.2 & 20 \\
\hline Manganese, filtered, $\mu \mathrm{g} / \mathrm{L}$ & 31.1 & 456 & 62.1 & 3.8 \\
\hline Selenium, filtered, $\mu \mathrm{g} / \mathrm{L}$ & .4 & 5.1 & 8.9 & 24.0 \\
\hline Uranium, filtered, $\mu \mathrm{g} / \mathrm{L}$ & 6.52 & 13.0 & 62.0 & 63.6 \\
\hline Zinc, filtered, $\mu \mathrm{g} / \mathrm{L}$ & 11.8 & 3.7 & 2.5 & 12.4 \\
\hline
\end{tabular}

the rain, and concentrations of almost all constituents were diluted compared to samples upstream and downstream. Dilution of both selenium and sulfate was systematic for stream group 4 as indicated by the decreased concentrations along a 1:1 slope (fig. 31). Concentrations of major ions in groups 3 and 5 are similar to one another and are greater than concentrations of major ions in group 4. Dividing concentrations of group 4, which generally are more dilute, by the average concentration of groups 3 and 5, yields a dilution factor between 62 and 69 percent caused by rainfall.

Samples from the headwaters (TGH) subreach were from the wetland reach of the stream and comprise stream group 1. High concentrations of manganese in three stream samples (fig. 32) were likely caused by reducing conditions in the streambed materials that caused the release of dissolved manganese to the stream (manganese, like iron, occurs as a dissolved (soluble) cation under reduced condition and forms insoluble oxides under oxidizing conditions). A similar pattern was observed in Emigration Creek, Utah for both manganese and iron (Kimball and others, 2008). The change to stream group 2 occurred downstream from Hampden Avenue, where Toll Gate Creek is confined to a concrete-lined channel, beginning at about 1,794 m. Many constituents have similar concentrations in samples from stream groups 1 and 2. For example, selenium and sulfate concentrations are nearly equal (table 12), but constituents, like iron and manganese, that are most affected by reduced conditions in the wetland reach upstream from Hampden Avenue have greater concentrations in samples of stream group 1.

At 5,330 m, just downstream from Buckley Road, the channel is again unlined, and the stream chemical character changes to that of stream group 3 . This change likely occurs because of the inflow of seepage from the surrounding area that particularly increases the concentrations of selenium and sulfate (fig. 29), but also could be caused, in part, by the selenium and sulfate concentrations added upstream at the culvert inflow at 4,707 $\mathrm{m}$. The generally greater concentrations of selenium, sulfate, and manganese downstream from 4,707 m in stream groups 3 and 4 than in groups 1 and 2 (figs. 29, 31, and 32) indicate that the inflows that have the greatest effect on instream concentrations of selenium occur downstream from the concrete-lined channel.

Samples in stream group 5 are located in the lower injection subreach (TGL). This group generally had the greatest concentrations of selenium, major ions, and uranium, likely in response to several inflows from inflow group 4 that had high concentrations of all these constituents. Without the effect of some rain during the period of sampling for the lower injection subreach, the concentrations would likely have been greater than those observed. 

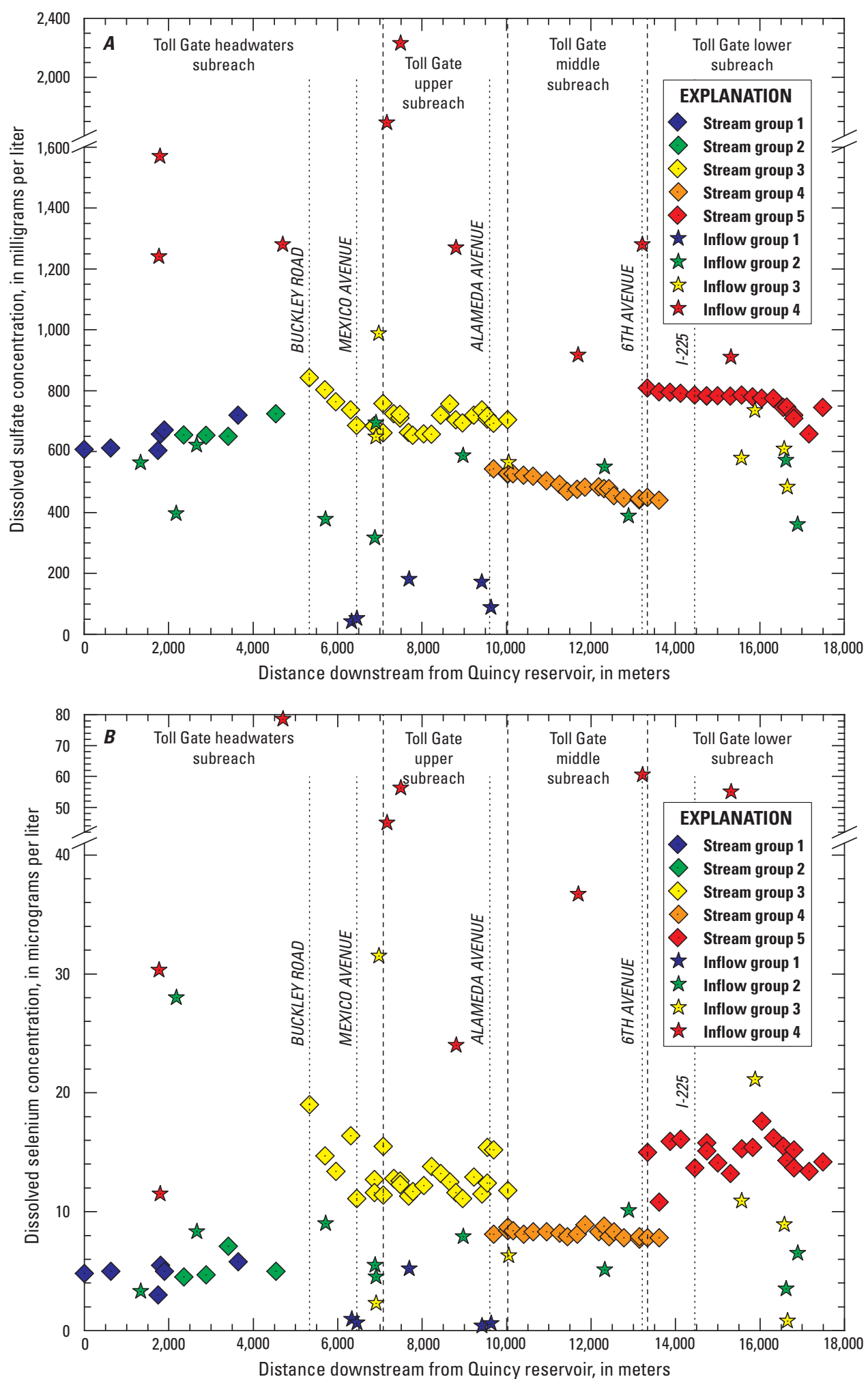

Figure 29. Graphs showing dissolved $A$, selenium and $B$, sulfate concentrations related to distance downstream from Quincy Reservoir, and cluster analysis results for stream and inflow samples, Toll Gate Creek, July-August 2007. 

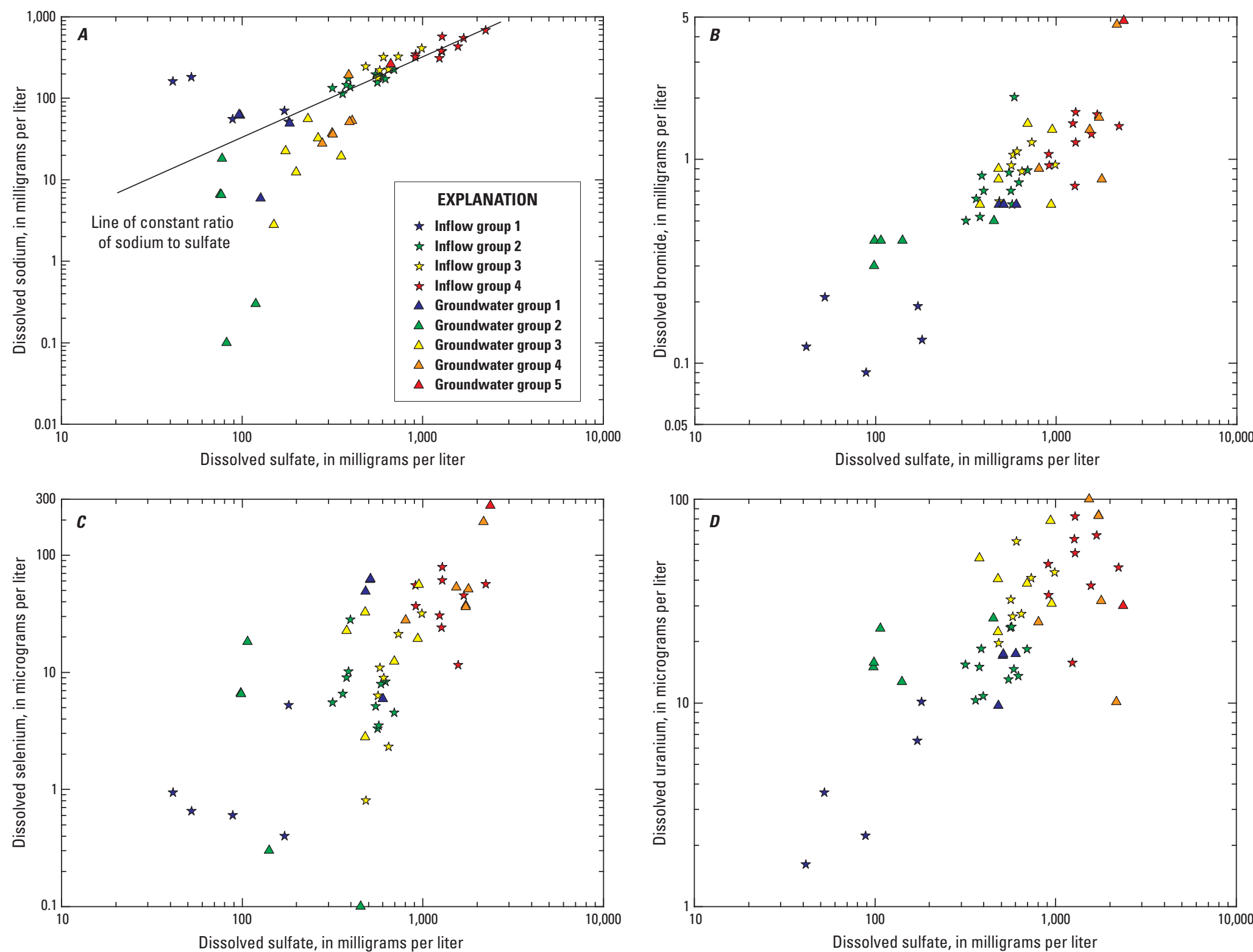

Figure 30. Graphs showing variation of $A$, sodium, $B$, bromide, $C$, selenium, and $D$, uranium concentrations with sulfate concentration, and clusteranalysis results (inflow and groundwater groups derived from cluster analysis) for surface-water inflows and groundwater along the study reach, Toll Gate Creek, July-August 2007. 
Table 12. Representative samples from stream groups defined by cluster analysis, Toll Gate Creek, July-August 2007.

[TGH, Toll Gate headwaters subreach; TGU, Toll Gate upper subreach; TGM, Toll Gate middle subreach; TGL, Toll Gate lower subreach; mg/L, milligrams per liter; $\mathrm{CaCO}_{3}$, calcium carbonate; $\mathrm{SiO}_{2}$, silica; $\mu \mathrm{g} / \mathrm{L}$, micrograms per liter; m, meter]

\begin{tabular}{|c|c|c|c|c|c|}
\hline \multirow[b]{2}{*}{ Constituent } & \multicolumn{5}{|c|}{ Group } \\
\hline & $\begin{array}{c}1 \\
\text { Upstream from } \\
2,356 \mathrm{~m} \\
\text { (TGH) }\end{array}$ & $\begin{array}{c}2 \\
\text { From } 2,356 \text { to } \\
5,330 \mathrm{~m} \\
\text { (TGH) }\end{array}$ & $\begin{array}{c}3 \\
\text { Upper sampling subreach from } \\
5,956 \text { to } 7,327 \mathrm{~m} \text { and upper } \\
\text { injection subreach } \\
\text { (mostly TGU) }\end{array}$ & $\begin{array}{c}4 \\
\text { Middle injection } \\
\text { subreach after } \\
\text { storm } \\
\text { (TGM) }\end{array}$ & $\begin{array}{c}5 \\
\text { Lower injection } \\
\text { subreach plus } \\
5,330 \text { to } 5,956 \mathrm{~m} \\
\text { (mostly TGL) }\end{array}$ \\
\hline Distance, meters & 1,809 & 2,886 & 8,444 & 11,441 & 15,003 \\
\hline Number of samples & 6 & 4 & 24 & 20 & 21 \\
\hline $\mathrm{pH}$, standard units & 7.9 & 8.7 & 7.9 & 8.2 & 8.4 \\
\hline Calcium, filtered, in $\mathrm{mg} / \mathrm{L}$ & 207 & 154 & 200 & 144 & 215 \\
\hline Magnesium, filtered, in $\mathrm{mg} / \mathrm{L}$ & 42.4 & 39.9 & 40.5 & 27.3 & 40.1 \\
\hline Sodium, filtered, in $\mathrm{mg} / \mathrm{L}$ & 181 & 178 & 226 & 144 & 252 \\
\hline Alkalinity as $\mathrm{CaCO}_{3}$, in $\mathrm{mg} / \mathrm{L}$ & 255 & 100 & 193 & 166 & 177 \\
\hline Sulfate, filtered, in $\mathrm{mg} / \mathrm{L}$ & 657 & 654 & 720 & 469 & 784 \\
\hline Bromide, filtered, in $\mathrm{mg} / \mathrm{L}$ & 0.82 & 0.79 & 2.69 & 1.11 & 2.35 \\
\hline Chloride, filtered, in $\mathrm{mg} / \mathrm{L}$ & 119 & 122 & 143 & 92.3 & 151 \\
\hline Fluoride, filtered, in $\mathrm{mg} / \mathrm{L}$ & 0.71 & 0.62 & 0.62 & 0.56 & 0.64 \\
\hline Silica as $\mathrm{SiO}_{2}$, in $\mathrm{mg} / \mathrm{L}$ & 15.5 & 12 & 13.3 & 10.8 & 10.7 \\
\hline Aluminum, filtered, in $\mu \mathrm{g} / \mathrm{L}$ & 5 & 7.3 & 1.6 & 18.2 & 15.8 \\
\hline Iron, filtered, in $\mu \mathrm{g} / \mathrm{L}$ & 27 & 23.8 & 15 & 13 & 12 \\
\hline Manganese, filtered, in $\mu \mathrm{g} / \mathrm{L}$ & 1,220 & 40.1 & 391 & 144 & 133 \\
\hline Selenium, filtered, in $\mu \mathrm{g} / \mathrm{L}$ & 5.5 & 4.7 & 13.2 & 7.9 & 14.1 \\
\hline Uranium, filtered, in $\mu \mathrm{g} / \mathrm{L}$ & 21.1 & 16.5 & 18.8 & 13.4 & 21.6 \\
\hline Zinc, filtered, in $\mu \mathrm{g} / \mathrm{L}$ & 0.89 & 0.98 & 1.6 & 2.4 & 0.97 \\
\hline
\end{tabular}

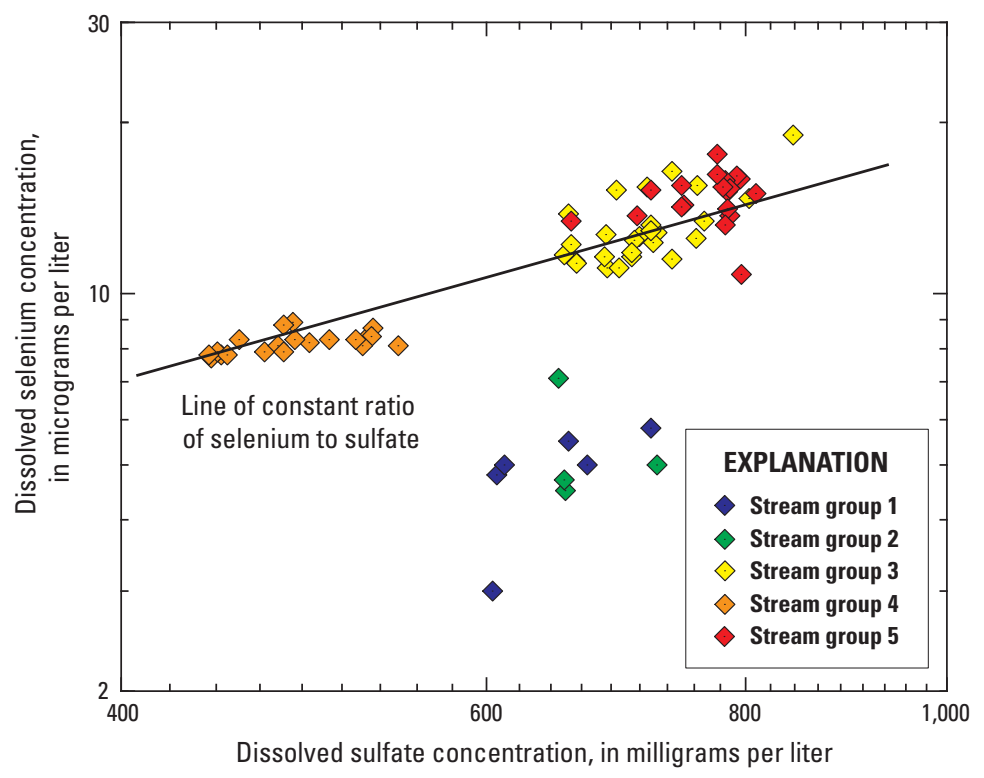

Figure 31. Graph showing relation of dissolved selenium and sulfate concentration, and cluster-analysis results (stream groups derived from cluster analysis in table 12) for stream samples, Toll Gate Creek, JulyAugust 2007. 


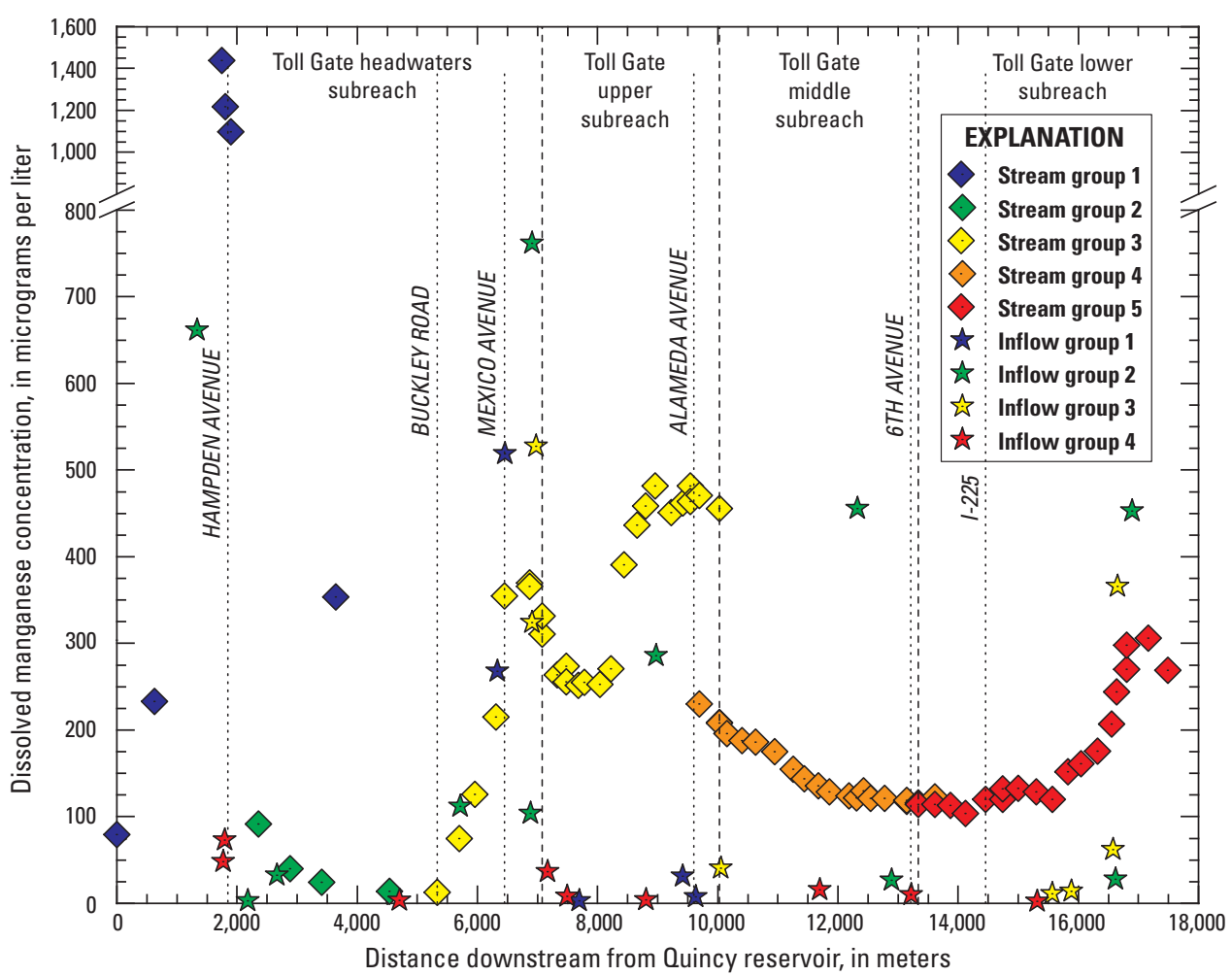

Figure 32. Graph showing variation of manganese concentration with distance downstream from Quincy Reservoir, and cluster analysis results (Stream and Inflow groups defined on table 12 and table 11) for stream and inflow samples along the study reach, Toll Gate Creek, Aurora, Colorado, July-August 2007.

\section{Hydrogen- and Oxygen-Isotope Ratios as Indicators of Evaporation}

All of the groundwater samples and a selected subset of inflow and stream samples in the Toll Gate Creek watershed were analyzed for the stable-isotope ratios of hydrogen $\left(\delta^{2} \mathrm{H}\right)$ and oxygen $\left(\delta^{18} \mathrm{O}\right)$ of water as an indication of the water origin and the processes that may have affected the water since its origin (Clark and Fritz, 1997). Hydrogen- and oxygenisotope ratios for the Toll Gate Creek groundwater, inflow, and stream samples plot below and with lesser slopes than the global meteoric water line (GMWL; Craig, 1961) and the local meteoric water line (LMWL) for northeastern Colorado (Harvey, 2005) (fig. 33) indicating that they likely represent meteoric water (precipitation) which has been affected by evaporation (Clark and Fritz, 1997).

There are at least three possible explanations for the hydrogen- and oxygen-isotopic data distribution. The first explanation is that because these data fall along an evaporation line with a slope of about 6 and a correlation coefficient of 0.97 (fig. 33), the study-area samples may have all evolved through varying degrees of evaporation from a single source of water (Clark and Fritz, 1997) having a composition determined by the intersection of the LMWL and the evaporation line $\left(\delta^{18} \mathrm{O}=-15.99, \delta^{2} \mathrm{H}=-118.0\right)$. Although these results do indicate evaporation has affected the groundwater, inflow, and stream samples, it is unlikely that all samples were derived from water having a single isotopic composition. A second more likely explanation is that samples had an original composition that plots along the LMWL and were then subject to varying amounts of evaporation as indicated by evaporation arrows between the meteoric water lines and the evaporation line in figure 33. Location of samples along a meteoric water line is controlled by the temperature of precipitation with samples from colder precipitation having lower isotope ratios than samples from warmer precipitation (Clark and Fritz, 1997). A third explanation is that the evaporation line in figure 33 is a mixing line along which samples plotting near the center of the line are mixtures of samples having lesser (depleted) isotopic ratios and samples having greater (enriched) isotopic ratios (Clark and Fritz, 1997). However, the evaporation line likely does not represent a mixing line because the samples are not physically located along groundwater or surface-water flow paths where mixing would occur. 


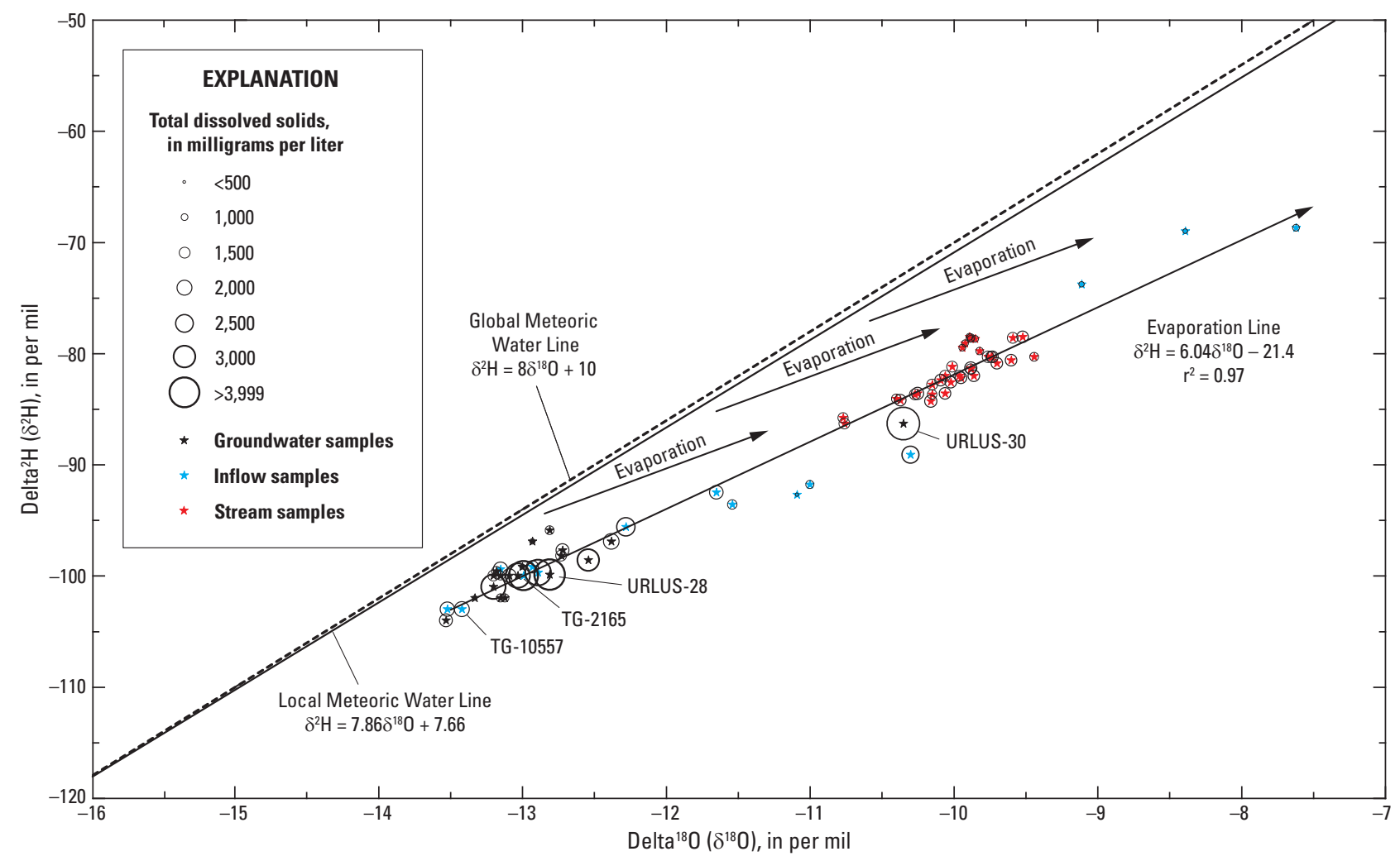

Figure 33. Graph showing global meteoric water line, local meteoric water line, and $\delta^{2} \mathrm{H}$ related to $\delta^{18} 0$ ratios and total dissolved solids concentration for groundwater, inflow, and stream samples, Toll Gate Creek, July-August 2007. Total dissolved solids symbols are continuously scaled. Several sizes are shown for reference in the explanation.

Groundwater samples plot nearer the GMWL and the LMWL than stream samples, indicating groundwater samples were less affected by evaporation than stream samples. The Toll Gate Creek inflow samples plot all along the evaporation line. Some of the inflow samples are most similar to groundwater samples, including 5 of the 11 inflows with the greatest selenium concentrations, 2 of which are the springs TG-2165 and TG-10557 (table 7). Some of the inflow samples have hydrogen- and oxygen-isotope ratios intermediate to the groundwater and stream samples, and some indicate more evaporation than stream samples.

Evaporation concentrates dissolved constituents in water and also affects the isotope ratios. The greater the evaporation, whether along a single evaporative line or from various starting points on the LMWL, the greater the $\delta^{18} \mathrm{O}$. Consequently, positive correlation between $\delta^{18} \mathrm{O}$ and dissolved selenium and TDS may indicate whether evaporation processes are effectively concentrating dissolved selenium and TDS. This analysis for groundwater, inflow, and stream samples produced mixed results. Correlations with $\delta^{18} \mathrm{O}$ in groundwater samples were strong and positive for dissolved selenium (linear correlation coefficient $r=0.77$, $\mathrm{p}$-value less than 0.001) and TDS $(r=0.58$; $p$-value less than
$0.01)$ indicating that evaporation may have contributed to increased selenium and TDS concentrations. These correlations, however, were leveraged by one sample, URLUS- 30 . When this sample was removed from the analysis, the correlations were no longer strong or significant $\left(\delta^{18} \mathrm{O}\right.$ and dissolved selenium, $\mathrm{r}=0.25$, $\mathrm{p}$-value $=0.31 ; \delta^{18} \mathrm{O}$ and TDS, $\mathrm{r}=0.28$, $\mathrm{p}$-value $=0.26$ ). Similarly, for stream samples, correlation between $\delta^{18} \mathrm{O}$ and selenium was weak and not highly significant $(\mathrm{r}=0.35$, $\mathrm{p}$-value $=0.04)$ and correlation between $\delta^{18} \mathrm{O}$ and TDS was not significant $(\mathrm{r}=-0.11$, $\mathrm{p}$-value $=0.52)$, indicating that evaporation is not the primary process affecting surface-water quality in Toll Gate Creek. Finally, correlations for inflow samples were negative and somewhat significant $\left(\delta^{18} \mathrm{O}\right.$ and dissolved selenium, $\mathrm{r}=-0.53$, $\mathrm{p}$-value $=0.04 ; \delta^{18} \mathrm{O}$ and TDS, $\mathrm{r}=-0.61$, $\mathrm{p}$-value $\left.=0.014\right)$ consistent with the understanding that inflow samples represent a wide range of hydrologic conditions such that their chemistry is affected by a variety of processes. The TDS range in figure 33 helps emphasize that the relation between isotope ratios and TDS concentration is not straightforward, and that the three inflow samples having the most enriched isotopic ratios and theoretically most affected by evaporation have TDS concentrations less than $500 \mathrm{mg} / \mathrm{L}$. 
To quantify the role of evaporation in concentrating solutes in the water, the maximum percentage of evaporative loss was calculated for each sample having an isotope analysis. The calculations of evaporative loss represent the maximum possible amount of evaporative concentration because they assume that the isotopic compositions for all samples were derived from water with a single isotopic composition $\left(\delta^{18} \mathrm{O}=-15.99 ; \mathrm{d}^{2} \mathrm{H}=-118.0\right)$. This simplifying assumption is made for the purpose of performing the following calculations, but the isotopic composition of water in the study area likely was not the result of evaporation from one single fixed isotopic composition because in practice the temperature and thus isotopic composition of precipitation likely varied spatially and seasonally.

The percentage of evaporative loss was calculated from the oxygen-isotope ratio for each sample with a stable-isotope analysis following the methods of Clark and Fritz (1997). The fractional water loss from evaporation can be modeled according to Rayleigh distillation and is a function of the measured oxygen-isotope ratio and equilibrium and kinetic fractionation factors (Clark and Fritz, 1997). For $\delta^{18} \mathrm{O}$, the evaporative enrichment is equal to the difference between the measured value for the sample and the $\delta^{18} \mathrm{O}$ value of precipitation at the intersection of the best-fit evaporative line with the LMWL $\left(\mathrm{d}^{18} \mathrm{O}=-15.99\right)$. The enrichment is equal to the sum of the equilibrium $\left(\varepsilon^{18} \mathrm{O}_{\mathrm{eq}}\right)$ and kinetic $\left(\Delta \varepsilon^{18} \mathrm{O}\right)$ enrichment factors $\left(\varepsilon^{18} \mathrm{O}_{\text {total }}\right)($ table $4-1)$ multiplied by the natural logarithm (ln) of the residual water fraction (f) (Clark and Fritz, 1997):

$$
\delta^{18} \mathrm{O}_{\text {sample }}-\delta^{18} \mathrm{O}_{\text {precipitation }}=\varepsilon^{18} \mathrm{O}_{\text {total }} * \ln (\mathrm{f})
$$

The equilibrium enrichment factor $(-10.60)$ was determined from a table as a function of mean annual air temperature, which was assumed equal to $10^{\circ} \mathrm{C}$ (Clark and Fritz, 1997, their table 1-4). The kinetic enrichment factor was calculated as a function of the humidity at the air-water interface, and humidity was determined graphically from the slope of the evaporative concentration line in figure 33 compared to figure $2-8$ in Clark and Fritz (1997):

$$
\Delta \varepsilon^{18} \mathrm{O}=-14.2 *(1-\text { humidity })
$$

By this method, humidity equals 85 percent. The residual water fraction was determined as an exponential function of the measured $\delta^{18} \mathrm{O}$ enrichment divided by $\varepsilon^{18} \mathrm{O}_{\text {total }}$ :

$$
\mathrm{f}=\operatorname{exponential}\left(\left(\delta^{18} \mathrm{O}_{\text {sample }}-\delta^{18} \mathrm{O}_{\text {precipitation }}\right) / \varepsilon^{18} \mathrm{O}_{\text {total }}\right)
$$

Evaporative loss is calculated as one minus the residual water fraction $(1-f)$ (Clark and Fritz, 1997).

Calculation results indicate that the evaporative loss varies from about 18 to 36 percent in groundwater samples, from about 18 to 48 percent in inflow samples, and from about 34 to 40 percent in stream samples (table 4-1). Forty-eight percent evaporation from a sample corresponds to a solute concentration factor of approximately 1.9. In other words, evaporation of 48 percent of the water from a sample would result in solute concentrations almost double the original concentrations. In the study area where TDS concentrations range from 472 to $4,440 \mathrm{mg} / \mathrm{L}$, or by a factor of 9.4 , evaporation can explain some, but probably not all, of the solute concentration observed in the water samples from the study area.

The isotopic results indicate that evaporation contributes to concentrating solutes in some samples (for example, URLUS-30). Strong correlations between dissolved selenium and TDS in groundwater and surface-water samples (tables 9 and 10) indicate that concentrated waters contain the greatest concentrations of selenium. However, evaporative loss less than 50 percent does not account for the observed TDS concentrations, and $\delta^{18} \mathrm{O}$ does not strongly or positively correlate with dissolved selenium or TDS in most groundwater, inflow, and stream samples. The lack of strong positive correlation between $\delta^{18} \mathrm{O}$ and dissolved selenium and TDS contrasted with strong correlations between dissolved selenium, TDS, and other major ions in water indicate that, for most samples, increased selenium and TDS concentrations are likely more a result of water-rock interaction with solute-generating rock layers, and possibly residence time in the groundwater system, than of evaporation. Evaporative concentration of solutes in groundwater and surface water, including selenium, is likely a secondary and not the primary process affecting concentrations of dissolved selenium and major ions in Toll Gate Creek.

\section{Apparent Groundwater Ages and Recharge Rates}

Apparent groundwater age (time since recharge) was estimated for groundwater samples using recharge temperatures calculated from dissolved-gas concentrations and the concentrations and ratios of chlorofluorocarbons (CFCs) CFC-11, CFC-12, CFC-113 and tritium in water compared to historical concentrations in the atmosphere (Plummer and Busenberg, 1999; Böhlke, J.K., U.S. Geological Survey, written commun., 2006; Steven Phillips, U.S. Geological Survey, written commun., 2010; table 8, this report). The computed groundwater ages are considered "apparent ages" because they are calculated using simplifying assumptions regarding transport processes (Plummer and Busenberg, 1999). The piston-flow model is a simple and commonly used method for calculating apparent groundwater age that assumes the tracer moved vertically through the aquifer in a piston-flow manner and is not altered by mixing or dispersion from the point of recharge to the point of measurement (Rupert and Plummer, 2004). All groundwater pumped from a well is, to some extent, mixed within the well bore (Plummer and Busenberg, 1999). Wells with long screened intervals can draw water of different ages from multiple parts of an aquifer, which mix in the well bore, and sampling results can produce mixed groundwater ages, complicating the calculation of apparent groundwater ages (Rupert and Plummer, 2004). The simplest case of mixing occurs if the water is a binary mixture of young (post-1953) 
and old (pre-1953) water, and a binary mixing model is used to estimate the young fraction of a mixed water (Rupert and Plummer, 2004).

Chlorofluorocarbons are stable, synthetic organic compounds that were developed in the early 1930s for refrigeration and have been used in a wide range of industrial and refrigerant applications (Plummer and Friedman, 1999). The use of CFC refrigerants, their release to the atmosphere, and the subsequent recharge of CFCs to groundwater make these compounds excellent tracers for estimating the apparent age of groundwater recharged since the 1950s through the 1990s (Plummer and Busenberg, 1999). Because atmospheric concentrations of CFCs have declined since the 1990s, dating of groundwater recharged since the 1990s using CFC concentrations can be uncertain (Peter McMahon, U.S. Geological Survey, written commun., 2011).

Groundwater-age dating with CFCs is based on Henry's law of gas solubility, which is affected by recharge temperature, excess air in the water samples, and recharge altitude (Plummer and Busenberg, 1999). The recharge temperature is the groundwater temperature at the water table at the time of recharge and is affected by mean air temperature at the time of recharge. Excess air is air dissolved in groundwater in excess of that determined by solubility equilibrium with atmospheric gasses (Rupert and Plummer, 2009). Excess air can be trapped and dissolved in groundwater when the water table rises rapidly in the capillary fringe and is determined by comparing the ratio of nitrogen gas $\left(\mathrm{N}_{2}\right)$ to argon (Ar) in air to the equilibrium solubility ratio of $\mathrm{N}_{2}$ to $\mathrm{Ar}$ in water (Rupert and Plummer, 2009). The presence of excess air can add CFCs to groundwater and, if not accounted for in age interpretations, causes a young age bias (Plummer and Busenberg, 1999). Concentrations of dissolved gases $\mathrm{N}_{2}$ and $\mathrm{Ar}$ in groundwater were used to estimate recharge temperature and excess air following the methods of Plummer and Busenberg (1999). Recharge altitude was assumed equal to land-surface altitude at the sampling location.

Tritium is another groundwater-age tracer, the concentrations of which can be used as a check on CFC apparent groundwater ages. Atmospheric thermonuclear testing from 1952 through the 1960s resulted in the release of tritium to the atmosphere and to precipitation recharge such that the presence and concentrations of tritium in groundwater can be used to estimate the apparent age and mixtures of groundwater recharged since 1953 (Clark and Fritz, 1997). Atmospheric tritium concentrations peaked in 1963 (Clark and Fritz, 1997) and have been decreasing since that time because of the exchange of water with the oceans, the short half-life of tritium, and the discontinuation of most atmospheric thermonuclear weapons testing (Rupert and Plummer, 2004). Tritium concentrations in precipitation prior to thermonuclear weapons testing are not well known but probably did not exceed 2 to 8 tritium units (TU) (Plummer and others, 1993). Because tritium has a half-life of 12.32 years, water derived from precipitation before thermonuclear weapons testing would contain a maximum tritium concentration of 0.12 to 0.5 TU by the early 2000s (Rupert and Plummer, 2004). Waters with tritium activities greater than about $30 \mathrm{TU}$ contain a considerable component of recharge from the 1960s, and waters with no tritium activity (less than a detection limit of about 1 TU) are considered old (pre-1953) waters (Clark and Fritz, 1997).

For the groundwater samples from the Toll Gate Creek study area, $\mathrm{CFC}$ and tritium concentrations were used to estimate groundwater age. The use of multiple tracers (CFCs and tritium) proved advantageous to the interpretation of groundwater-age results because low-oxygen and reducing conditions in addition to thin saturated thickness in the shallow groundwater system complicated interpretations of the CFC results. Under low-oxygen and reducing conditions, CFCs can be degraded by microbial action (Plummer and others, 1993), and CFC concentrations were degraded in at least five wells-MC-2B, SCTC-5, WT-14, WT-4, and WT-8 - as indicated by the presence of low-oxygen concentrations, excess nitrogen gas and (or) methane (table 8). Apparent groundwater ages calculated for wells with low-oxygen or reducing conditions are based on selected $\mathrm{CFC}$ concentrations (CFC-12) not affected by degradation and (or) tritium concentrations. In addition, if the water table is drawn down and the well screened interval is exposed to the atmosphere during sampling, CFCs in groundwater can be contaminated by present-day atmospheric concentrations of CFCs, such that the resulting data are not useful for estimating apparent groundwater age. Contamination of CFCs occurred at wells ET-1, ET-2, SC-6, URLUS-18, URLUS-30, WT-12, WT-19, and WT-8, and the groundwater-age calculation for these samples was based on noncontaminated CFC concentrations and (or) tritium concentrations as noted in table 8 .

On the basis of CFC results, tritium concentrations, and the piston-flow model, most apparent groundwater ages for the Toll Gate Creek groundwater system range from 11 to 45 years with apparent groundwater-recharge dates ranging from the early 1960s to 1997 (table 8). As described previously in this section, low-oxygen and reducing conditions in addition to CFC contamination complicated the groundwater-age interpretations. However, for all of the wells except URLUS-30 and URLUS-28, the CFC concentrations indicate piston-flow model groundwater recharge and young water with apparent recharge dates from the mid-1960s through the mid-1990s that are supported by the tritium concentration data.

The groundwater-age estimates in combination with the oxygen-isotope and water-quality data indicate multiple hydrologic and geochemical processes are occurring in the groundwater system of Toll Gate Creek to mobilize selenium and major ions. At wells URLUS-30 and URLUS-28, low tritium concentrations combined with the CFC concentrations indicate that groundwater samples from these locations contained mixtures of old and young water. The young fraction of water for these two samples was recharged in the 1990s, and the old fraction of water was recharged prior to 1953. As described in the "Selenium Concentrations" section of this report, the maximum concentrations of selenium in groundwater were 
detected in samples from wells URLUS-30 $(264 \mu \mathrm{g} / \mathrm{L})$ and URLUS-28 $(192 \mu \mathrm{g} / \mathrm{L})$, the two wells are completed in bedrock materials, and water quality at these two wells is characterized by elevated concentrations of dissolved selenium, TDS, major ions, organic carbon, and nitrate under low-oxygen conditions. Compared to groundwater samples with young apparent ages, the component of old groundwater in samples with the greatest dissolved selenium and TDS concentrations indicates that selenium and other major ions were dissolved from the claystone bedrock by water-rock interaction over long groundwater-residence times on the order of 50 years or longer. The groundwater-age results support the hypothesis that long groundwater-residence times in Denver Formation claystone bedrock promote dissolution of selenium and major ions in groundwater. The presence of young water with elevated selenium concentrations in wells completed in surficial materials indicates that selenium also can be mobilized and transported by more recent recharge during shorter groundwater-residence times on the order of 10 to 40 years, although the concentrations of dissolved selenium and major ions were greatest in samples containing a fraction of old water. Denitrification of nitrate also may be contributing to selenium oxidation.

The apparent groundwater ages (A) were used to estimate piston-flow recharge rates $(\mathrm{R})$ as a linear function of porosity $(\Phi)$ and sample depth (midpoint of the screened or saturated interval) below the water table (d) (Böhlke and others, 2007):

$$
\mathrm{R}=(\Phi * \mathrm{~d}) / \mathrm{A}
$$

A porosity of 0.25 was assumed for the calculations, although values could range from 0.15 to 0.44 (Robson, 1983). The results (table 8 ) indicate recharge rates that ranged from about 0.5 to 4.8 inches per year (in/yr). For wells URLUS-30 and URLUS-28, recharge rates for the old fraction of groundwater were 1.0 and $0.7 \mathrm{in} / \mathrm{yr}$, respectively, and represent natural precipitation recharge rates prior to urbanization. Recharge rates for the young fraction of groundwater represent urbanized recharge rates and ranged from 4.4 to $4.8 \mathrm{in} / \mathrm{yr}$ at well URLUS-30 (1996-1997 apparent recharge year of young fraction). A rate of $2.2 \mathrm{in} / \mathrm{yr}$ was estimated for the young fraction of groundwater at well URLUS-28 (1990 apparent recharge year). For the remaining wells, the apparent recharge year ranged from 1974 (well SCTC-5) to 1990 (well ET-2) or after 1990 (well SC-6), and recharge rates ranged from $0.5 \mathrm{in} / \mathrm{yr}$ at well $\mathrm{MC}-2 \mathrm{~B}$, located in an undeveloped part of the watershed, to $4.7 \mathrm{in} / \mathrm{yr}$ at well SC-6 located in an urbanized area outside the watershed. All of these rates are near the range of natural precipitation ( 0.5 to $1.1 \mathrm{in} / \mathrm{yr}$ ) and urban ( 2.5 to $3.5 \mathrm{in} / \mathrm{yr}$ ) recharge rates estimated by Paschke (2011) for the Denver Basin.

\section{Selenium in Solid Materials}

Previous analysis of total selenium in Denver Formation claystone and lignite horizons (Katherine Walton Day, U.S. Geological Survey, written commun., 2007) indicate total selenium concentrations ranged from 0.11 to as much as 13 parts per million (ppm) and were greatest in samples containing indications of reducing conditions (dark gray to black claystones and lignite horizons). Water-soluble selenium concentrations in associated paste extractions ranged from 8 to $4,600 \mu \mathrm{g} / \mathrm{L}$ and were greatest in dark gray claystone. The lowest water-soluble selenium concentrations were observed for more oxidized samples that contained staining from oxidized iron minerals. Low water-soluble selenium concentrations also were observed for a lignite sample. The dark gray (unweathered and reduced), organic-rich claystone of the Denver Formation contained greater water-soluble selenium sources than the weathered and oxidized claystone indicating that perhaps selenium has already been leached from the weathered bedrock.

The present study analyzed additional solids samples from the core of well ET-1 to examine the vertical distribution of possible selenium sources in a representative stratigraphic column. The vertical distribution of water-extractable selenium in the core from well ET-1 (fig. 34) indicates that the greatest concentration of water-soluble selenium (117 ppm) occurred at a depth of 31 feet in the less-weathered claystone of the Denver Formation. Substantial water-soluble selenium also can occur in the more weathered claystone $(70 \mathrm{ppm}$ in core from well ET-1 at 25 to 27 feet), whereas little watersoluble selenium occurred in the sand and clay deposits of surficial materials.

\section{Geologic Sources and Processes Affecting Selenium Loading}

Water-quality and solids-sampling results from this study indicate ongoing weathering processes release watersoluble selenium from underlying claystone bedrock with subsequent cycling of selenium in the aquatic environment of Toll Gate Creek (fig. 35). Water-soluble selenium concentrations in paste extractions from core were greatest for lessweathered dark gray claystone indicating the organic-rich claystone is a primary geologic source of selenium in the Toll Gate Creek watershed. Selenium can occur as seleniumbearing pyrite or as an organic complex in the organic-rich claystone. Oxidized (weathered) claystone samples with iron oxides contained lesser water-soluble selenium concentrations than the less-weathered samples indicating that selenium may be somewhat leached from weathered bedrock or that selenite may be strongly sorbing to iron oxides. Secondary salts observed in the weathered zone also may be a source of selenium, but their composition was not specifically addressed by the solids analyses.

Selenium is mobilized from the claystones into nearsurface groundwater by oxidation and weathering processes. Exposure of the Denver Formation selenium-bearing bedrock to oxidizing atmospheric conditions, surface water, and groundwater oxidizes selenide held as a trace element in pyrite 


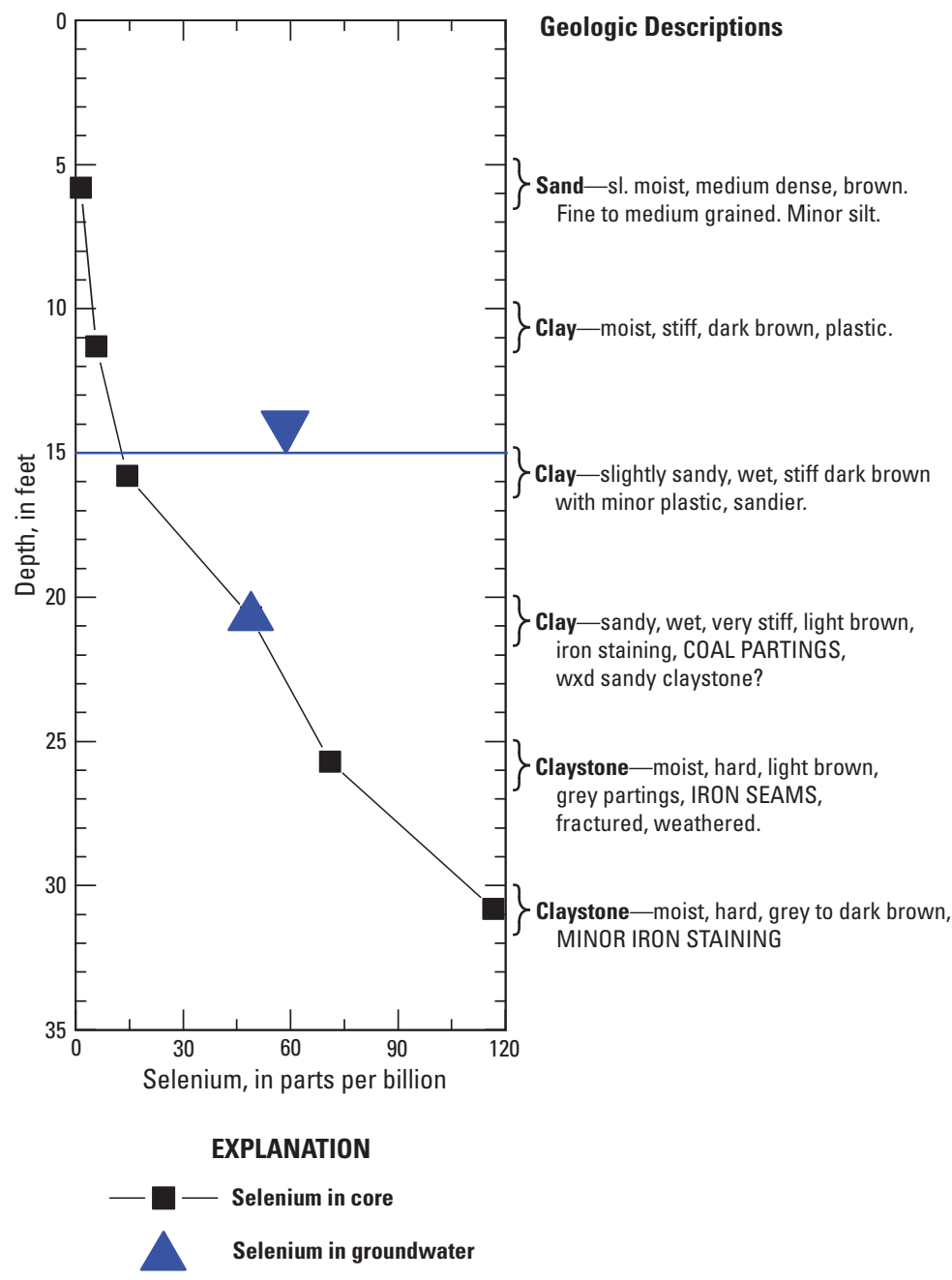

Figure 34. Graph showing water-extractable selenium concentration in core in relation to depth below land surface for well ET-1.

or in complexes with organic matter to selenite and selenate. Secondary weathering products including iron oxides and selenium-bearing salts formed in the semiarid climate can serve as sinks or sources of selenium. Selenite is strongly sorbed to iron oxides making it less soluble in water, whereas selenium-bearing salts in the weathered zone can later dissolve and release oxidized forms of selenium to groundwater and surface water.

Groundwater selenium and major-ion concentrations in combination with oxygen-isotopic results and apparent groundwater ages indicate water-rock interaction, to a lesser extent evaporation, and possibly nitrate-reduction processes, are affecting selenium concentrations in groundwater. At the two wells with the greatest selenium concentrations (URLUS-30 and URLUS-28), a component of old groundwater indicates water-rock interaction over long groundwaterresidence times, on the order of 50 years or longer, as the primary selenium-dissolution process that contributes to the greatest dissolved selenium concentrations. Oxygen-isotope results indicate evaporative loss in the semiarid climate also contributes to concentrating dissolved selenium and major ions. However, evaporation cannot fully account for the observed selenium and TDS concentrations indicating that evapoconcentration is a secondary chemical process affecting selenium and major-ion concentrations The presence of young water and dissolved nitrate in wells completed in surficial materials indicates that selenium also is mobilized and transported by more recent recharge during shorter groundwater-residence times on the order of 10 to 40 years. Denitrification of nitrate also may be contributing to selenium oxidation.

Selenium-bearing evaporative salts observed along streambanks are another source of selenium to Toll Gate Creek surface water. Ongoing evaporative processes concentrate selenium and major ions from underlying bedrock and sediments, and selenium-bearing evaporative salts are deposited 


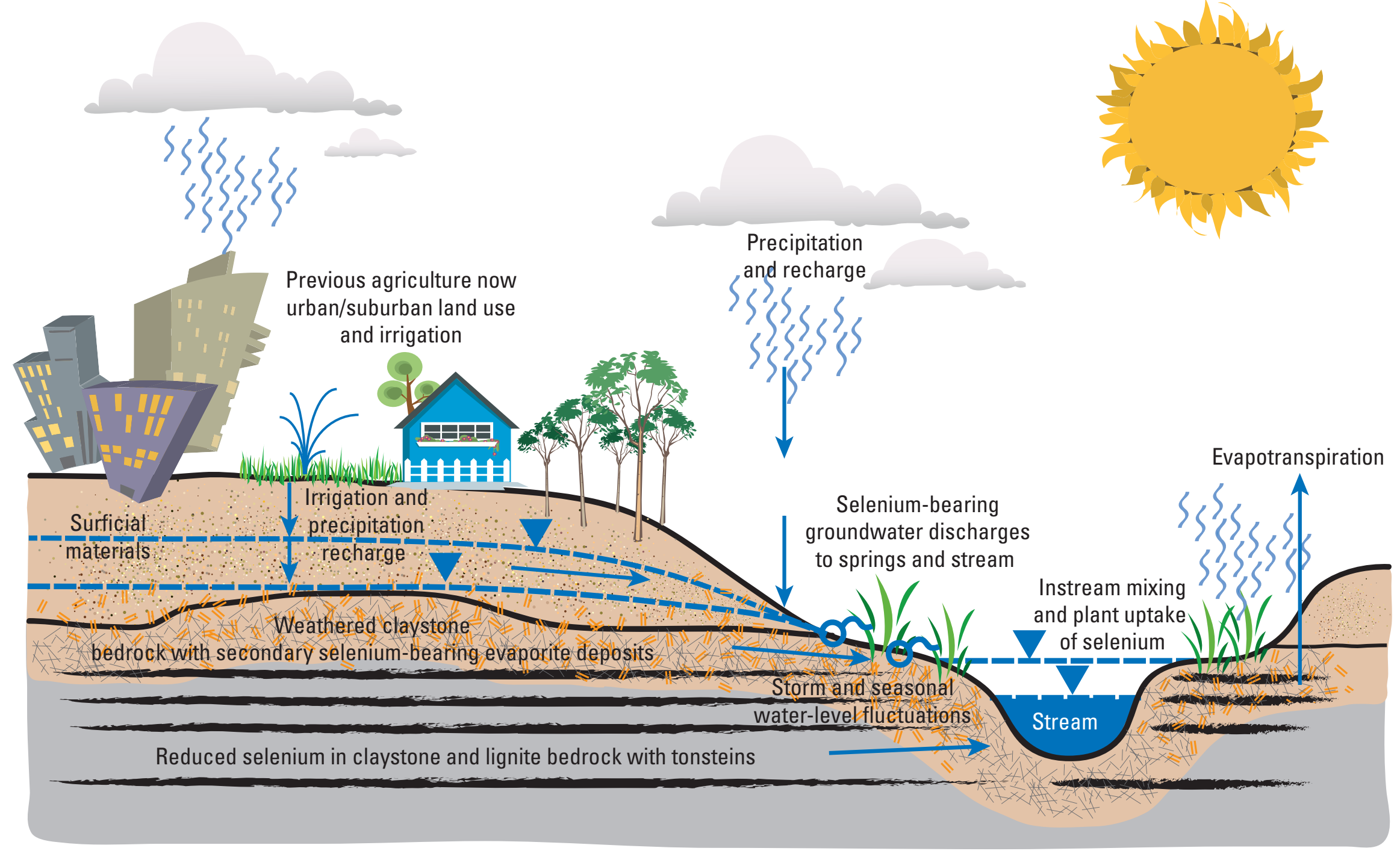

Figure 35. Conceptual diagram of selenium occurrence in the Toll Gate Creek watershed. 
along streambanks (Herring and Walton-Day, 2007). These evaporative deposits are rapidly dissolved during high streamflow events contributing selenium and TDS to Toll Gate Creek as was observed by this study during a rain storm.

Dissolved selenium is transported toward Toll Gate Creek in groundwater, which discharges to surface water from seeps, springs, and engineered culverts. Concentrations of selenium in groundwater greater than $50 \mu \mathrm{g} / \mathrm{L}$ generally occurred in wells upgradient of West Toll Gate Creek in areas where the Denver Formation crops out at the land surface, and inflow with the greatest selenium concentrations ( 45 and $56 \mu \mathrm{g} / \mathrm{L}$ ) occurred near the western extent of the Denver Formation outcrop area downstream from Buckley Road. The distribution of the 11 inflows with the greatest selenium concentrations indicates that in addition to the springs downstream from Buckley Road, culverts that drain parts of the watershed downstream from 6th Avenue also contribute selenium load to Toll Gate Creek. The distribution of selenium concentrations in groundwater, springs, and the 11 inflows with the greatest selenium concentrations indicates that groundwater in the Denver Formation bedrock is a source of selenium loading to Toll Gate Creek and that selenium discharge to the stream is distributed along the entire length of the study reach downstream from the concrete-lined channel. Where the stream is incised and flows directly on bedrock, selenium likely can be mobilized directly to surface water by oxidation and (or) dissolution processes.

Surface-water chemistry and selenium concentrations exhibited less variability than concentrations of selenium for inflows or groundwater indicating that hydrological, geochemical, and biological instream processes were effectively mixing the inflow and groundwater discharge received by the stream during the summer low-flow study period. Several geochemical reactions could account for the observed variation and attenuation of stream-selenium concentrations. In the upper headwaters subreach (TGH), selenium concentrations were about $5 \mu \mathrm{g} / \mathrm{L}$. Wetlands in the upper TGH create reducing conditions, as evidenced by increases in dissolved manganese concentrations, where selenium can be reduced to insoluble forms such as selenide and can be removed from the water column by precipitation of selenium-bearing sulfide minerals or by adsorption onto and (or) uptake into organic matter and plant material. Downstream from the wetland reach is the concrete-lined channel where selenium concentrations also remained near $5 \mu \mathrm{g} / \mathrm{L}$. Oxidizing conditions exist in the concrete-lined channel, which contains no plants, so that reducing conditions cannot account for the low selenium concentrations. The lack of inflows in the reach are evidence that the concrete lining likely prevents groundwater and thus selenium discharge to this section of Toll Gate Creek. Downstream from the concrete-lined channel, inflows with selenium concentrations greater than the stream contribute selenium load to surface water; however, stream selenium concentrations were less than $20 \mu \mathrm{g} / \mathrm{L}$ all along Toll Gate Creek. This apparent attenuation of selenium concentration indicates that selenium was being removed from the water column by reactions and was not transported conservatively through the surface-water system. Several reactions could account for decreases in stream selenium concentrations. Where oxidized conditions are present in rapidly flowing reaches, oxidized and soluble forms of selenium (selenite and selenate) may adsorb to iron oxides or clays that are present in the streambed sediment and substrate. Oxidized selenium compounds also can be precipitated as selenium-bearing salts along streambanks as evapotranspiration occurs, and selenium-bearing evaporative salts were identified along Toll Gate Creek by Herring and Walton-Day (2007). Where reducing conditions are present in wetland areas or stagnant stream reaches with abundant plant matter, selenium can be reduced to insoluble forms such as selenide and can be removed from the water column by precipitation of selenium-bearing sulfide minerals or by adsorption onto and (or) uptake into organic matter such as algae, phytoplankton, waterweeds, or other plant material. The presence of large algal blooms and abundant macrophytes, in conjuction with the attenuation of selenium and nitrate in surface water, indicates that plant uptake was likely decreasing stream selenium concentrations during the summer low-flow study period.

\section{Summary}

Toll Gate Creek is a perennial stream in Aurora, Colo., where dissolved selenium concentrations have consistently exceeded the State of Colorado aquatic-life standard for selenium of $4.6 \mu \mathrm{g} / \mathrm{L}$ since the early 2000s. Toll Gate Creek drains a suburban area where surface water is derived from local rainfall and snowmelt runoff, urban storm drainage, and groundwater discharge from the encompassing watershed. No known point discharges exist that could account for the observed selenium concentrations. Previous work concluded that greater than 85 percent of the selenium loading to Toll Gate Creek originates from the tributary of West Toll Gate Creek, and groundwater discharge to the stream was considered as the source of selenium to Toll Gate Creek. Groundwater hydrology of the Toll Gate Creek watershed is characterized by variably saturated water-table conditions in Quaternary surficial materials and the top of the underlying Cretaceous- to Tertiary-aged Denver Formation bedrock with groundwater flow toward Toll Gate Creek. Groundwater-quality data from the U.S. Geological Survey National Water-Quality Assessment program indicated the presence of dissolved selenium concentrations at the water table in the vicinity of Toll Gate Creek for samples collected in 2003. These observations provided evidence that selenium concentrations in Toll Gate Creek are the result of water-rock interaction among groundwater, surface water, and the selenium-bearing bedrock of the Denver Formation, with subsequent flow and discharge to Toll Gate Creek.

The U.S. Geological Survey, in cooperation with the City of Aurora, Colorado, Utilities Department, conducted this study of Toll Gate Creek in late July and early August 2007 to further characterize streamflow and water-quality conditions 
including geologic sources and processes affecting selenium loading in the Toll Gate Creek watershed for low-flow conditions. The 18-km reach of Toll Gate Creek extending from downstream from Quincy Reservoir to the confluence with Sand Creek was assessed using four spatially overlapping synoptic-sampling subreaches. Field reconnaissance identified all inflows for the 18-km reach of Toll Gate Creek, and its tributary West Toll Gate Creek, and a series of synoptic-sampling and tracer-injection events were employed to assess selenium loading to the stream. Mass-balance methods were applied to the synoptic-sampling and tracer-injection results to estimate streamflow and develop spatial profiles of concentration and load for selenium and other chemical constituents in Toll Gate Creek surface water. Concurrent groundwater sampling determined concentrations of selenium and other chemical constituents in groundwater in areas surrounding the Toll Gate Creek study reaches. Multivariate principal-component analysis was used to group samples and to suggest common sources for dissolved selenium and other dissolved constituents. Results for hydrogen and oxygen stable-isotope ratios, groundwater-age interpretations, and chemical analyses of water-soluble paste extractions from core samples are presented, and interpretation of the hydrologic and geochemical data support conclusions regarding the geologic sources and processes affecting selenium loading in the Toll Gate Creek watershed.

Streamflow conditions observed and measured during the synoptic water-quality study represent summer base-flow conditions and rainfall conditions for July 2007. A relatively dry period preceded the primary synoptic sampling period, as only one rainfall event was recorded in the watershed from June 19, 2007 through July 26, 2007. This dry period was followed by a series of rainfall events from July 27 through August 1, 2007 that increased streamflow. Synoptic sampling activities generally were conducted 1-2 days following each rainfall event such that samples were collected as streamflow was receding. The effects of rainfall on streamflow estimates and synoptic-sampling results were most pronounced for the Toll Gate Creek middle injection (TGM) subreach. The final streamflow profile for July 2007 provides evidence that streamflow increases steadily within each subreach and for the entire study reach, indicating that Toll Gate Creek is a gaining stream. The lack of large tributary inflows and the spatial distribution of small tributary inflows, seeps, and springs indicate that diffuse and discrete groundwater inflow supports streamflow during low-flow conditions along the entire $18-\mathrm{km}$ stream reach. Streamflow in the TGM subreach was substantially greater than that in the other subreaches because of rainfall, and streamflow in the TGM subreach increased rapidly in response to the rainfall as would be expected in a suburban setting where paved areas and channelization increase surfacewater runoff and decrease runoff transit time to local drainages compared to undeveloped areas.

Dissolved selenium concentrations within all sampled subreaches of Toll Gate Creek exceeded the Colorado aquaticlife standard of $4.6 \mu \mathrm{g} / \mathrm{L}$ during July and August 2007. Selenium concentrations in the upper portion of the Toll
Gate Creek headwaters (TGH) subreach were close to the aquatic-life standard at about $5 \mu \mathrm{g} / \mathrm{L}$, whereas concentrations downstream from Buckley Road and a concrete-lined channel in subreaches not substantially affected by rainfall during sampling generally were greater than $10 \mu \mathrm{g} / \mathrm{L}$ and less than $20 \mu \mathrm{g} / \mathrm{L}$. The maximum stream selenium concentration of $19 \mu \mathrm{g} / \mathrm{L}$ occurred at Buckley Road at the downstream end of the concrete-lined channel and downstream from a right-bank culvert inflow with a selenium concentration of $78.5 \mu \mathrm{g} / \mathrm{L}$. Dissolved selenium concentrations less than $10 \mu \mathrm{g} / \mathrm{L}$ for the TGM subreach are attributed to dilution that occurred because of rainfall and the resulting increased streamflow. Stream selenium concentrations exhibited less variability than inflow or concentrations of selenium in groundwater and remained less than $20 \mu \mathrm{g} / \mathrm{L}$ all along Toll Gate Creek despite the presence of sampled inflows contributing selenium to the stream indicating that selenium was being removed from the water column by chemical or biological reactions and that selenium is not transported conservatively through the surface-water system.

Of the 32 discrete sampled inflows, selenium concentrations in 11 inflows were greater than $21 \mu \mathrm{g} / \mathrm{L}$, and selenium concentrations at the remaining 21 inflows were less than $12 \mu \mathrm{g} / \mathrm{L}$. The 11 inflows exceeding $21 \mu \mathrm{g} / \mathrm{L}$ represent groundwater discharge to Toll Gate Creek. Nine of the 11 inflows emanate from culverts, which are channelized tributaries and storm drains that collect groundwater discharge as well as surface-water runoff. Two of the 11 inflows are springs where groundwater visibly discharges along the contact between surficial materials and the underlying less-permeable claystone bedrock. Concentrations of selenium in groundwater were, in general, substantially greater than inflow and stream selenium concentrations and the Colorado aquatic-life standard of $4.6 \mu \mathrm{g} / \mathrm{L}$, and at some locations were greater than the U.S. Environmental Protection Agency primary drinking-water standard of $50 \mu \mathrm{g} / \mathrm{L}$. Spatially, concentrations of selenium in groundwater greater than $50 \mu \mathrm{g} / \mathrm{L}$ generally occurred in wells upgradient of West Toll Gate Creek in areas where the Denver Formation crops out at the land surface and in wells completed in bedrock. The distribution of selenium concentrations in groundwater, springs, and the 11 inflows with the greatest selenium concentrations indicates that shallow groundwater in surficial materials and the Denver Formation bedrock is a source of selenium loading to Toll Gate Creek and that selenium loading is distributed along the entire length of the study reach downstream from the concrete-lined channel. Where the stream is incised and flows directly on bedrock, selenium also can be mobilized directly to surface water by oxidation and (or) dissolution processes.

Selenium loading profiles for the four study reaches overlap in a consistent fashion and indicate a steady increase in selenium mass load in Toll Gate Creek from downstream from Quincy Reservoir to the confluence with Sand Creek. This steady increase is consistent with the spatial distribution of inflows with the greatest selenium concentration, contributions from diffuse groundwater discharge, and the steady downstream increase in streamflow. Further, the smooth 
transition of the loading profile from one subreach to the next indicates that the loading analysis is not adversely affected by the increased streamflow associated with rainfall during sampling of the TGM subreach. The loading analysis for the TGM subreach is consistent with the other subreaches despite the increased streamflow because the net effect of increased streamflow was dilution, a process that does not influence constituent load.

General water quality in the Toll Gate Creek watershed is characterized by total dissolved solids (TDS) concentrations that frequently exceed the U.S. Environmental Protection Agency secondary drinking-water standard of $500 \mathrm{mg} / \mathrm{L}$, near-neutral to slightly alkaline $\mathrm{pH}$ values, a wide range of redox conditions, detections of nitrate in groundwater, hydrogen- and oxygen-isotope ratios indicative of active evaporative processes, and groundwater-age interpretations of primarily young water recharged since the 1960s. The widespread occurrence of increased total dissolved solids concentrations in groundwater, inflows, and stream samples indicates groundwater is interacting with and dissolving soluble minerals and salts from the surficial materials and claystone bedrock as it moves downgradient from recharge areas toward Toll Gate Creek. The relatively small variability in TDS concentrations for stream samples compared to groundwater and inflow samples indicates that hydrological, geochemical, and biologic instream processes are effectively mixing the inflows and groundwater discharge received by the stream.

Dissolved-oxygen concentrations in groundwater samples were measured as indicators of redox conditions, and concentrations ranged from 0.1 to 7.4 milligrams per liter indicating a wide range of redox conditions in the groundwater system. Oxidizing conditions were present in shallow groundwater outside of the Toll Gate Creek watershed as indicated by dissolved-oxygen concentrations of 7.4 and 3.5 milligrams per liter, whereas low-oxygen to reducing conditions were present within the groundwater system in the Toll Gate Creek watershed. Dissolved-oxygen and selenium concentrations were not strongly correlated. Nitrate was detected at concentrations greater than 0.5 milligrams per liter in samples from 16 of the 19 groundwater monitoring wells, and the detection of nitrate and nitrogen gas in monitoring wells where dissolved oxygen also was detected indicates that mixed redox conditions and denitrification processes are occurring at some locations in the groundwater system. Nitrate concentrations in stream samples were much less than and less variable than in groundwater or inflow samples. Nitrate in surface water is likely attenuated by plant uptake as evidenced by large algal blooms and abundant aquatic macrophytes noted during field activities.

For stream samples, dissolved selenium concentrations were strongly correlated with concentrations of total dissolved solids and dissolved sodium, sulfate, uranium, and nitrate. For groundwater samples, dissolved selenium concentrations were strongly correlated with concentrations of total dissolved solids, dissolved calcium, magnesium, sodium, sulfate, chloride, bromide, nitrate, and organic carbon and oxygen-isotope ratio. The strong correlations among dissolved constituents indicate that the constituents are likely derived from the same or related geologic sources. Evaporative loss, calculated from the oxygen-isotope ratios, supports the hypothesis that evaporation contributes to concentrating solutes in some samples; however, the degree of evaporative loss (less than 50 percent) in samples does not account for the observed total dissolved solids concentrations, and $\delta^{18} \mathrm{O}$ does not strongly or positively correlate with dissolved selenium or total dissolved solids in most groundwater, inflow, and stream samples. The lack of strong positive correlation between $\delta^{18} \mathrm{O}$ and dissolved selenium and total dissolved solids contrasted with strong correlations between dissolved selenium, total dissolved solids and other major ions in water indicate that, for most samples, increased selenium and total dissolved solids concentrations are likely more a result of water-rock interaction with solutegenerating rock layers, and possibly residence time in the groundwater system, than of evaporation. Evaporative concentration of solutes in groundwater and surface water, including selenium, is likely a secondary and not the primary process affecting concentrations of dissolved selenium and major ions in Toll Gate Creek.

Apparent groundwater age (time since recharge) was estimated for groundwater samples using recharge temperatures calculated from dissolved-gas concentrations and the concentrations and ratios of chlorofluorocarbons and tritium in water compared to historical concentrations in the atmosphere assuming a piston-flow model. The use of multiple tracers (chlorofluorocarbons and tritium) proved advantageous to the interpretation of groundwater-age results because low-oxygen and reducing conditions in addition to thin saturated thickness in the shallow groundwater system complicated interpretations of the chlorofluorocarbon results. Most apparent groundwater ages for the Toll Gate Creek groundwater system range from 11 to 45 years with apparent groundwater-recharge dates ranging from the early 1960s to 1997. At wells URLUS-30 and URLUS-28, which exhibited the greatest selenium concentrations, low tritium concentrations indicative of old water (pre1953) were detected in conjunction with chlorofluorocarbon concentrations that are indicative of young water (post-1953). The results indicate that groundwater samples from these locations contained a mixture of old and young water, and the young fraction of water for these two samples was recharged in the 1990s. Compared to groundwater samples with young apparent ages, the component of old groundwater in samples from the two wells with the greatest dissolved selenium and total dissolved solids concentrations supports the conclusion that long groundwater-residence times in Denver Formation claystone bedrock promotes dissolution of selenium and major ions in groundwater.

Water-quality and solids-sampling results from this study indicate ongoing weathering processes release watersoluble selenium from underlying claystone bedrock with subsequent cycling of selenium in the aquatic environment of Toll Gate Creek. Water-soluble selenium concentrations in paste extractions from core were greatest for less-weathered dark gray claystone indicating the organic-rich claystone 
is a primary geologic source of selenium in the Toll Gate Creek watershed. Selenium can occur as selenium-bearing pyrite or as an organic complex in the organic-rich claystone. Oxidized (weathered) claystone samples with iron oxides contained lesser water-soluble selenium concentrations than the less-weathered samples indicating that selenium may be somewhat leached from weathered bedrock or that selenite may be strongly sorbing to iron oxides. Secondary weathering products include iron oxides and selenium-bearing salts accumulated in the weathered zone in the semi-arid climate that also can serve as sources or sinks of selenium. Selenite is strongly sorbed to iron oxides making it less soluble in water, while selenium-bearing salts in the weathered zone can later dissolve and release oxidized forms of selenium to groundwater and surface water while secondary salts observed in the weathered zone may be a source of selenium, their composition was not specifically addressed by this study. Selenium-bearing evaporative salts observed along streambanks also are a source of selenium to Toll Gate Creek surface water. Ongoing evaporative processes concentrate selenium and major ions from underlying bedrock and sediments, and evaporative selenium-bearing salts are deposited along streambanks. These evaporative deposits are rapidly dissolved during groundwater recharge and high streamflow events contributing selenium and total dissolved solids to Toll Gate Creek. Surface-water chemistry and selenium concentrations exhibited less variability than inflow or concentrations of selenium in groundwater indicating that hydrological, geochemical, and biological instream processes were effectively mixing the inflow and groundwater discharge received by the stream. Selenium and nitrate concentrations in surface water were likely attenuated by plant uptake during the summer low-flow study period.

\section{Acknowledgments}

The authors gratefully acknowledge the City of Aurora Utilities Department, the USGS Cooperative Water Program, and the USGS Toxic Substance Hydrology Program for their support of this study.

\section{References Cited}

Adriano, D.C., 2001, Trace elements in terrestrial environments: New York, Springer, 867 p.

American Public Health Association, 1998, 3120 Metals by plasma emission spectrometry, in Standard methods for the examination of water and wastewater (20th ed.): Washington, D.C., American Public Health Association, American Water Works Association, and Water Environment Federation, p.3-37-3-43.
Balistrieri, L.S., and Chao, T.T., 1987, Adsorption of selenium by amorphous iron oxyhydroxide and manganese dioxide: Geochemica et Cosmochimica Acta, v. 54, p. 739-751.

Bencala, K.E., and McKnight, D.M., 1987, Identifying instream variability - Sampling iron in an acidic stream, in Averett, R.C., and McKnight, D.M., eds., Chemical quality of water and the hydrologic cycle: Chelsea, Mich., Lewis Publishers, Inc., p. 255-269.

Besser, J.M., Brumbaugh, W.G., May, T.W., Church, S.E., and Kimball, B.A., 2001, Bioavailability of metals in stream food webs and hazards to brook trout (Salvelinus fontinalis) in the upper Animas River watershed, Colorado: Archive of Environmental Contamination and Toxicology, v. 40, p. 48-59.

Böhlke, J.K., Verstraeten, I.M., and Kraemer, T.F., 2007, Effects of surface-water irrigation on sources, fluxes, and residence times of water, nitrate, and uranium in an alluvial aquifer: Applied Geochemistry, v. 22, p. 152-174.

Boult, K.A., Cowper, M.M., Heath, T.G., Sato, H., Shibutani, T., and Yui, M., 1998, Towards an understanding of the sorption of U(VI) and Se(IV) on sodium bentonite: Journal of Contaminant Hydrology, v. 35, p. 141-150.

Brenton, R.W., and Arnett, T.L., 1993, Methods of analysis by the U.S. Geological Survey National Water Quality Laboratory-Determination of dissolved organic carbon by UV-promoted persulfate oxidation and infrared spectrometry: U.S. Geological Survey Open-File Report 92-480, $12 \mathrm{p}$.

Brinton, T.I., Antweiler, R.C., and Taylor, H.E., 1996, Method for the determination of dissolved chloride, nitrate, and sulfate in natural water using Ion Chromatography: U.S. Geological Survey Open-File Report 95-426A, $16 \mathrm{p}$.

Brown and Caldwell and Chadwick Ecological Consultants, 2003, Selenium stakeholders 2002 comprehensive data analysis technical memorandum: prepared for annual Selenium Stakeholders Meeting, April 2003, Brown and Caldwell and Chadwick Ecological Consultants, 55 p. plus appendices.

Burt, Rebecca, ed., 2004, Soil survey laboratory methods manual: U.S. Department of Agriculture, Soil Conservation Service, Soil Survey Investigations Report no. 42, version 4.0; methods 4F2, 4F2a1, 4F2a1a1, 8A, 8A1.

Clark, I.D., and Fritz, P., 1997, Environmental isotopes in hydrogeology: New York, CRC Press, 328 p.

Coleman, L., Bragg, L.J., and Finkelman, R.B., 1993, Distribution and mode of occurrence of selenium in U.S. coals: Environmental Geochemistry and Health, v. 15, no. 4, p. 215-227. 
Colorado Department of Public Health and Environment, 2008, Regulation No. 31, Basic standards and methodology for surface water (5 CCR 1002-31): accessed November 28, 2009, at http://www.cdphe.state.co.us/regulations/wqccregs/ 100231wqccbasicstandardsforsurfacewater.pdf.

Coplen, T.B., Wildman, J.D., and Chen, J., 1991, Improvements in the gaseous hydrogen-water equilibration technique for hydrogen isotope ratio analysis: Analytical Chemistry, v. 63, p. $910-912$.

Craig, H., 1961, Isotopic variations in meteoric waters: Science, v. 133, p. 1702-1703.

Davidson, D.F., and Powers, H.A., 1959, Selenium content of some volcanic rocks from western United States and Hawaiian Islands: U.S. Geological Survey Bulletin 1084-C, p. 69-81.

Driscoll, L.B., 1975, Land-use classification map of the Colorado Springs-Castle Rock Area, Front Range urban corridor: U.S. Geological Survey Miscellaneous Investigation Series Map I-857-B, 1 sheet.

Epstein, S. and Mayeda, T., 1953, Variation of O-18 content of water from natural sources: Geochimica et Cosmochimica Acta, v. 4, p. 213-224.

Faires, L.M., 1993, Methods of analysis by the U.S. Geological Survey National Water Quality LaboratoryDetermination of metals in water by inductively coupled plasma-mass spectrometry: U.S. Geological Survey OpenFile Report 92-634, 28 p.

Farrar, J.W., 1997, Results of the U.S. Geological Survey's analytical evaluation program for standard reference samples: T-147 (trace constituents), T-149 (trace constituents), M-142 (major constituents), N-53 (nutrient constituents), N-54 (nutrient constituents), P-28 (low ionic strength constituents), GW-1 (groundwater constituents), and Hg-24 (mercury): U.S. Geological Survey Open-File Report 97-553, 184 p., available at: http://pubs.er.usgs.gov/ usgspubs/ofr/ofr 97553 .

Fernández-González, A., Andara, A., Alía, J.M., and Prieto, M., 2006, Miscibility in the $\left.\mathrm{CaSO}_{4} \cdot 2 \mathrm{H}_{2} \mathrm{O}\right)-\mathrm{CaSeO}_{4}-2 \mathrm{H}_{2} \mathrm{O}$ system-Implications for the crysallisation and dehydration behavior: Chemical Geology, v. 225, p. 256-265.

Fernández-Martínez, Alejandro, and Charlet, Laurent, 2009, Selenium environmental cycling and bioavailability-A structural chemist point of view: Reviews in Environmental Science and Biotechnology, v. 8, p. 81-110.

Fishman, M.J., ed., 1993, Methods of analysis by the U.S. Geological Survey National Water Quality LaboratoryDetermination of inorganic and organic constituents in water and fluvial sediments: U.S. Geological Survey OpenFile Report 93-125, $217 \mathrm{p}$.
Fishman, M.J., and Friedman, L.C., 1989, Methods for determination of inorganic substances in water and fluvial sediments: U.S. Geological Survey Techniques of Water-Resources Investigations, book 5, chap. A1, 545 p.

Friedman, J.M., and Lee, V.L., 2002, Extreme floods, channel change, and riparian forests along ephemeral steams: Ecological Monographs, v. 72, no. 3, p. 409-425.

Garbarino, J.R., Kanagy, L.K., and Cree, M.E., 2006, Determination of elements in natural-water, biota, sediment and soil samples using collision/reaction cell inductively coupled plasma-mass spectrometry: U.S. Geological Survey Techniques and Methods, book 5, sec. B, chap.1, 88 p.

Garbarino, J.R., and Struzeski, T.M., 1998, Methods of analysis by the U.S. Geological Survey National Water Quality Laboratory-Determination of elements in whole-water digests using inductively coupled plasma-optical emission spectrometry and inductively coupled plasma-mass spectrometry: U.S. Geological Survey Open-File Report 98-165, 101 p.

Gissel-Nielsen, G., Gupta, U.S., Lamand, M., and Westermarck, T., 1984, Selenium in soils and plants and its importance in livestock and human nutrition: Advances in Agronomy, v. 37, p. 397-460.

Gluskoter, H.J., Ruch, R.R., Miller, W.G., Cahill, R.A., Dreher, G.B., and Kuhn, J.K., 1977, Trace elements in coal-Occurrence and distribution: Illinois State Geological Survey Circular, no. 499, 154 p.

Green, G.N., 1995, Digital geologic map of Colorado in ARC/ INFO format: U.S. Geological Survey Open-File Report 92-0507, available at http://pubs.usgs.gov/of/1992/ofr-92$0507 \%$.

Hansen, W.R., Chronic, J., and Matelock, J., 1978, Climatography of the Front Range urban corridor and vicinity, Colorado: U.S. Geological Survey Professional Paper 1019, 59 p.

Harvey, F.E., 2005, Stable hydrogen and oxygen isotope composition of precipitation in northeastern Colorado: Journal of the American Water Resources Association, April 2005, p. 447-459.

Helsel, D.R., and Hirsch, R.M., 2002, Statistical Methods in Water Resources: U.S. Geological Survey Techniques of Water-Resources Investigations of the United States Geological Survey, Book 4. Hydrologic Analysis and Interpretation, Chapter A3, 534 p.

Herring, J.R., and Walton-Day, Katherine, 2007, Selenium and other elements in water and adjacent rock and sediment of Toll Gate Creek, Aurora, Arapahoe County, Colorado, December 2003 through March 2004: U.S. Geological Survey Scientific Investigations Report 2007-5018, 58 p.

Kaufman, L., and Rousseeuw, P.J., 1990, Finding groups in data: An introduction to cluster analysis: New York, Wiley, 368 p. 
Keith, J.R., and Maberry, J.O., 1973, Vegetation map of the Parker Quadrangle, Arapahoe and Douglas Counties, Colorado: U.S. Geological Survey Folio of the Parker Quadrangle, Colorado, Map I-770-N, 1 sheet.

Kilpatrick, F.A., and Cobb, E.D., 1985, Measurement of discharge using tracers: U.S. Geological Survey Techniques of Water-Resource Investigations, book 3, chap. A16, 52 p.

Kimball, B.A., Nimick, D.A., Gerner, L.J., and Runkel, R.L., 1999, Quantification of metal loading in Fisher Creek by tracer injection and synoptic sampling, Park County, Montana, August 1997: U.S. Geological Survey WaterResources Investigations Report 99-4119, 40 p.

Kimball, B.A., Runkel, R.L., and Walton-Day, Katherine, 2008, Principal locations of major-ion, trace-element, nitrate, and Escherichia coli loading to Emigration Creek, Salt Lake County, Utah, October 2005: U.S. Geological Survey Scientific Investigations Report 2008-5032, 33 p.

Kimball, B.A., Runkel, R.L., Walton-Day, Katherine, and Bencala, K.E., 2002, Assessment of metal loads in watersheds affected by acid mine drainage by using tracer injection and synoptic sampling - Cement Creek, Colorado, USA: Applied Geochemistry, v. 17, no. 9, p. 1183-1207, doi:10.1016/S0883-2927(02)00017-3.

Kimball, B.A., Walton-Day, Katherine, and Runkel, R.L., 2007, Quantification of metal loading by tracer injection and synoptic sampling, 1996-2000, in Church, S.E., von Guerard, P., and Finger, S.E., eds., Integrated investigations of environmental effects of historical mining in the Animas River watershed, San Juan County, Colorado: U.S. Geological Survey Professional Paper 1651, chap. E9, p. 417-495.

Kirkham, R.M., and Ladwig, L.R., 1979, Coal resources of the Denver and Cheyenne Basins, Colorado: Colorado Geological Survey, $70 \mathrm{p}$.

Koterba, M.T., Wilde, F.D., and Lapham, W.W., 1995, Groundwater data-collection protocols and procedures-Collection and documentation of water-quality samples and related data: U.S. Geological Survey Open-File Report 95-399, 114 p.

Knowles, R., 1982, Denitrification: Microbiology Reviews, v. 46 , p. $43-70$.

Kulp, T.R., and Pratt, L.M., 2004, Speciation and weathering of selenium in Upper Cretaceous chalk and shale from South Dakota and Wyoming, USA: Geochemica et Cosmochemica Acta, v. 68 , no. 18 , p. 3687-3701.

Lakin, H.W., 1961, Vertical and lateral distribution of selenium in sedimentary rocks of western United StatesSelenium in agriculture: U.S. Department of Agriculture Handbook 200, p. 12-24.
Lapham, W.W., Wilde, F.D., and Koterba, M.T., 1995, Ground-water data-collection protocols and procedures for the National Water-Quality Assessment programSelection, installation, and documentation of wells, and collection of related data: U.S. Geological Survey OpenFile Report 95-398, 71 p.

Lemly, A.D., 1985, Toxicology of selenium in a freshwater reservoir-implications for environmental hazard evaluation and safety: Ecotoxicology and Environmental Safety, v. 10, p. $314-338$.

Lemly, A.D., 1993, Guidelines for evaluating selenium data from aquatic monitoring and assessment studies: Environmental Monitoring and Assessment, v. 28, p. $83-100$.

Malisa, E.P., 2001, The behavior of selenium in geological processes: Environmental Geochemistry and Health, v. 23, p. $137-158$.

McNeal, J.M., and Balistrieri, L.S., 1989, Geochemistry and occurrence of selenium, an overview, in Jacobs, L.W., ed., Selenium in agriculture and the environment: Madison, Wisconsin, Soil Science Society of America, Inc., special publication no. 23, p. 1-13.

Nadler, C.T., and Schumm, S.A., 1981, Metamorphosis of South Platte and Arkansas Rivers, eastern Colorado: Physical Geology, v. 2, no. 2, p. 95-115.

Naftz, D.L., and Rice, J.A., 1989, Geochemical processes controlling selenium in ground water after mining, Powder River Basin, Wyoming, USA: Applied Geochemistry, v. 4, p. 565-575.

National Oceanic and Atmospheric Administration, 2003, Normal precipitation data for Colorado: accessed December 1, 2004, at http://www.ncdc.noaa.gov/oa/pub/data/coopprecip/colorado.txt.

Neuzil, S.G., Dulong, F.T., and Cecil, C.B., 2005, Spatial trends in ash yield, selenium, and other trace element concentrations in coal beds of the Appalachian Plateau Region, USA: U.S. Geological Survey Open-File Report 2005-1330, $18 \mathrm{p}$.

Nimick, D.A., Gammons, C.H., Cleasby, T.E., Madison, J.P., Skaar, D., Brick, C.M., 2003, Diel cycles in dissolved metal concentrations in streams - Occurrence and possible causes: Water Resources Research, v. 39, no. 9. p. 1247-1264, doi:10.1029/2002WR001571.

Ohlendorf, H.M., 1989, Bioaccumulation and effects of selenium in wildlife, in Jacobs, L.W., ed., Selenium in agriculture and the environment: Soil Science Society of America, p. 133-177. 
Ohlendorf, H.M., Hoffman, D.J., Saiki, M.K., and Aldrich, T.W., 1986, Embryonic mortality and abnormalities of aquatic birds - Apparent impacts by selenium from irrigation drainwater: Science of the Total Environment, v. 52, p. 49-63.

Paschke, S.S., ed., 2011, Groundwater availability of the Denver Basin aquifer system, Colorado: U.S. Geological Survey Professional Paper 1770, 274 p.

Paschke, S.S., Kimball, B.K., and Runkel, R.L., 2005, Quantification and simulation of metal loading to the upper Animas River, Eureka to Silverton, San Juan County, Colorado, September 1997 and August 1998: U.S. Geological Survey Scientific Investigations Report 2005-5054, 73 p.

Patton, C.J., and Kryskalla, J.R., 2003, Methods of analysis by the U.S. Geological Survey National Water Quality Laboratory_-Evaluation of alkaline persulfate digestion as an alternative to Kjeldahl digestion for determination of total and dissolved nitrogen and phosphorus in water: U.S. Geological Survey Water-Resources Investigations Report 03-4174, 33 p.

Plummer, L.N., Michel, R.L., Thurman, E.M., and Glynn, P.D., 1993, Environmental tracers for age dating young ground water, in Alley, W.M., ed., Regional ground-water quality: N.Y., Van Nostrand Reinhold, p. 255-294.

Plummer, L.N., and Busenberg, Eurybiades, 1999, Chlorofluorocarbons - Tools for dating and tracing young groundwater, in Cook, P., and Herczeg, A., eds., Environmental tracers in subsurface hydrology: Boston, Kluwer Academic Publishers, chap. 15, p. 441-478.

Plummer, L.N., and Friedman, L.C., 1999, Tracing and dating young ground water: U.S. Geological Survey Fact Sheet FS-134-99, 4 p.

Presser, T.S., 1994, The Kesterson effect: Environmental Management, v. 18, no. 3, p. 437-454.

Presser, T.S., and Ohlendorf, H.M., 1987, Biogeochemical cycling of selenium in the San Joaquin Valley, California: Environmental Management, v. 11, p. 805-821.

Pyle, R.M., 1998, The Thunder Tree, 1998 edition: New York, The Lyons Press, 240 p.

Rantz, S.E., and others, 1982, Measurement and computation of streamflow: Volume 1. Measurement of stage and discharge: U.S. Geological Survey Water-Supply Paper 2175, 284 p.

Robson, S.G., 1983, Hydraulic characteristics of the principal bedrock aquifers in the Denver Basin, Colorado: U.S. Geological Survey Hydraulic Investigations Atlas HA-659, scale 1:500,000, 3 sheets.

Robson, S.G., 1996, Geohydrology of the shallow aquifers in the Denver metropolitan area, Colorado: U.S. Geological Survey Hydrologic Atlas 736, 5 sheets.
Robson, S.G., and Romero, J.C., 1981, Geologic structure, hydrology, and water quality of the Denver aquifer in the Denver Basin, Colorado: U.S. Geological Survey Hydrologic Atlas 646, 3 sheets.

Robson, S.G., Van Slyke, G., and Graham, G., 1998, Structure, outcrop, and subcrop of the bedrock aquifers along the western margin of the Denver Basin, Colorado: U.S. Geological Survey Hydrologic Investigations Atlas HA-742, scale 1:50,000, 5 sheets.

Rose, S., and Long, A., 1988, Dissolved oxygen systematics in the Tucson Basin aquifer: Water Resources Research, v. 24, no. 1, p. 127-136.

Runkel, R.L., Bencala, K.E., Kimball, B.A., Walton-Day, Katherine, and Verplanck, P.L., 2009, A comparison of preand post-remediation water quality, Mineral Creek, Colorado: Hydrological Processes, v. 23, no. 23, p. 3319-3333.

Runkel, R.L., Kimball, B.A., Walton-Day, Katherine, and Verplanck, P.L., 2007, A simulation-based approach for estimating premining water quality, Red Mountain Creek, Colorado: Applied Geochemistry, v. 22, p. 1899-1918.

Rupert, M.G., and Plummer, L.N., 2004, Ground-water flow direction, water quality, recharge sources, and age, Great Sand Dunes National Monument, south-central Colorado, 2000-2001: U.S. Geological Survey Scientific Investigations Report 2004-5027, 28 p.

Rupert, M.G., and Plummer, L.N., 2009, Groundwater quality, age, and probability of contamination, Eagle River watershed valley-fill aquifer, north-central Colorado, 20062007: U.S. Geological Survey Scientific Investigations Report 2009-5082, 59 p.

Sindeeva, N.D., 1964, Mineralogy and types of deposits of selenium and tellurium: New York, Interscience Publishers, $363 \mathrm{p}$.

Stadtman, T.C., 1974, Selenium biochemistry: Science, v. 183, p. $915-922$.

Taylor, C.D., and Theodorakos, P.M., 2002, Rock sample preparation, in Taggert, J.E. ed., Analytical methods for chemical analysis of geologic and other materials: U.S. Geological Survey Open-File Report 02-223, chap. A1, p. A1-1-A1-5.

Thatcher, L.L., Janzer V.J., and Edwards K.W., 1977, Methods for determination of radioactive substances in water and fluvial sediments: U.S. Geological Survey Techniques of Water-Resources Investigations, book 5, chap. A5, p. 79-81.

Trimble, D.E., 1980, The geologic story of the Great Plains: U.S. Geological Survey Bulletin 1493, 55 p.

Tweto, Ogden, 1979, Geologic Map of Colorado: U.S. Geological Survey Special Geologic Map. 
U.S. Environmental Protection Agency, 1987, Data quality objectives for remedial response activities example scenario: RI/FS activities at a site with contaminated soils and groundwater: Washington, D.C., U.S. Environmental Protection Agency, Report EPA/540/G-87/004.

U.S. Environmental Protection Agency, 2003, National primary drinking-water standards: U.S. Environmental Protection Agency Office of Water fact sheet EPA 816-F-03-016, accessed November 2008, at http://www.epa.gov/safewater/ contaminants/index.html.

U.S. Geological Survey, variously dated, National field manual for the collection of water-quality data: U.S. Geological Survey Techniques of Water-Resources Investigations, book 9, chaps. A1-A9, available online at http://pubs.water.usgs. gov/twri9A.

Valkovic, V., 1983, Trace elements in coal: CRC Press, Inc, $304 \mathrm{p}$.

VanSlyke, G., Romero, J.C., Moravec, G., and Wacinski, A, 1988, Geologic structure, sandstone/siltstone isolith, and location of non-tributary ground water for the Denver aquifer, Denver Basin, Colorado: Colorado Division of Water Resources, Denver Basin Atlas no. 2 (DBA-2), 3 plates.

Walton-Day, Katherine, Flynn, J.L., Kimball, B.A., and Runkel, R.L., 2005, Mass loading of selected major and trace elements in Lake Fork Creek near Leadville, Colorado, September-October 2001: U.S. Geological Survey Scientific Investigations Report 2005-5151, 46 p.

Weres, O., Bowman, H.R., Goldstein, A., Smith, E.C., and Tsao, L., 1990, The effect of nitrate and organic matter upon mobility of selenium in groundwater and in a water treatment process: Water, Air, and Soil Pollution, v. 49, p. $251-272$.

White, A.F., and Dubrovsky, N.M., 1994, Chemical oxidationreduction controls on selenium mobility in groundwater systems, in Frankenberger, W.T., and Benson, S., eds., Selenium in the environment: New York, Marcel Dekker, p. 185-222.

White, A.F., Peterson, M.L., and Solbau, R.D., 1990, Measurement and interpretation of low levels of dissolved oxygen in ground water: Ground Water, v. 28, no. 4, p. 584-590.

Wilde, F.D., 2004, Cleaning of equipment for water sampling: U.S. Geological Survey Techniques of Water-Resources Investigations, book 9, chap. A3, 83 p.

Witham, C.S., Oppenheimer, C., and Horwell, C.J., 2004, Volcanic ash-leachates - a review and recommendations for sampling methods: Journal of Volcanology and Geothermal Research, v. 141, p. 299-326.
Yudovich, Y.E., and Ketris, M.P., 2006, Selenium in coala review: International Journal of Coal Geology, v. 67, p. 112-126.

Zellweger, G.W., Bencala, K.E., McKnight, D.M., Hirsch, R.M., and Kimball, B.A., 1988, Practical aspects of tracer experiments in acidic, metal-enriched streams, in Mallard, G.E., ed., U.S. Geological Survey Toxic Substances Hydrology Program-Surface-water contamination: U.S. Geological Survey Open-File Report 87-764, p. 125-130.

Publishing support provided by:

Denver Publishing Service Center

For more information concerning this publication, contact:

Director, USGS Colorado Water Science Center

Box 25046, Mail Stop 415

Denver, C0 80225

(303) 236-4882

Or visit the Colorado Water Science Center Web site at: http://co.water.usgs.gov/ 
Appendixes 


\section{Appendix 1. Development of Streamflow Estimates}

This appendix documents the development of a spatially detailed streamflow profile for the Toll Gate Creek study reach downstream from Buckley Road during the July-August 2007 period of study. Streamflow estimates for sampling locations upstream from Buckley Road are sparse and spatially variable and are not discussed herein.

\section{General Methodology}

Streamflow estimates were made at all stream sampling locations using current-meter measurements (Rantz and others, 1982) and (or) the tracer-dilution method (Kilpatrick and Cobb, 1985), as shown in table 1-1. Current-meter measurements were made using a handheld, Acoustic Doppler Velocimeter (ADV, FlowTracker ${ }^{\circledR}$ ). Most stream sampling locations had large cross-sectional areas relative to the amount of streamflow, leading to low velocities, near stagnant water, and the potential for reverse (upstream) flow. As such, most current-meter measurements are considered "poor" (error potentially greater than 8 percent). Current-meter measurements are available for most locations within the TGH, TGU, TGM, and TGL subreaches (table 1-1). Current-meter measurements were not practical for all TGH sampling locations upstream from Buckley Road because of shallow depths and low flow in the wetland reach and the concrete-lined channel.

Continuous, constant-rate injections of a conservative tracer (sodium bromide) were initiated at the upstream end of the TGU, TGM, and TGL subreaches to allow for the determination of streamflow using the tracer-dilution method (table 1-2). Each tracer injection continued for 2-3 days to allow for the attainment of a steady-state tracer plateau (Kimball and others, 2002; 2007). Given plateau conditions, tracer-dilution estimates of streamflow are given by (Kimball and others, 2007):

$$
Q=\left(Q_{i n j} C_{i n j}\right) /\left(C-C_{p}\right)
$$

where

$$
\begin{array}{cl}
Q & \text { is the tracer-dilution streamflow estimate }, \\
Q_{i n j} & \text { is the injection rate, } \\
C_{i n j} & \text { is the injectate concentration, } \\
C & \text { is the plateau tracer concentration, and } \\
C_{p} & \text { is the presynoptic tracer concentration } \\
Q \text { and } Q_{i n j}, & \text { are in cubic feet per second; } \\
C_{i n j}, C, & \text { and } \\
C_{p} & \text { are in milligrams of bromide per liter }) .
\end{array}
$$

Presynoptic and plateau tracer concentrations were obtained by sampling at each stream sampling location prior to the start of the tracer injection and on the synoptic sampling day, respectively (table 1-2).

Although theoretically straightforward, implementation of the tracer-dilution method was complicated by two factors. First, wide cross-sections made it necessary to collect width- and depth-integrated samples (U.S. Geological Survey,

\begin{tabular}{|c|c|c|c|c|c|c|c|}
\hline Sample ID & $\begin{array}{c}\text { Final } \\
\text { streamflow } \\
\text { estimate } \\
\left(\mathrm{ft}^{3} / \mathrm{s}\right)\end{array}$ & $\begin{array}{c}\text { Alternative } \\
\text { streamflow } \\
\text { estimate } \\
\left(\mathrm{ft}^{3} / \mathrm{s}\right)\end{array}$ & $\begin{array}{c}\text { Tracer- } \\
\text { dilution } \\
\text { streamflow } \\
\text { estimate } \\
\left(\mathrm{ft}^{3} / \mathrm{s}\right)\end{array}$ & $\begin{array}{c}\begin{array}{c}\text { Current- } \\
\text { meter }\end{array} \\
\text { measurement } \\
\left(\mathbf{f t}^{3} / \mathbf{s}\right)\end{array}$ & $\begin{array}{c}\text { Synoptic } \\
\text { bromide } \\
\text { concentration } \\
\text { (mg/L) }\end{array}$ & $\begin{array}{c}\text { Presynoptic } \\
\text { bromide } \\
\text { concentration } \\
\text { (mg/L) }\end{array}$ & $\begin{array}{c}\text { Adjusted } \\
\text { presynoptic } \\
\text { bromide } \\
\text { concentration } \\
\text { (mg/L) }\end{array}$ \\
\hline TGH-0 & 2.32 & 2.39 & -- & 3.88 & -- & -- & -- \\
\hline TGH-371 & 2.32 & 2.39 & -- & 2.32 & -- & -- & -- \\
\hline TGH-626 & 2.42 & 2.47 & -- & 2.42 & -- & -- & -- \\
\hline TGH-976 & 2.85 & 2.58 & -- & 2.85 & -- & -- & -- \\
\hline TGH-1118 & 2.52 & 2.63 & -- & 2.52 & -- & -- & -- \\
\hline TGH-1536 & 2.86 & 2.75 & -- & 2.86 & -- & -- & -- \\
\hline TGH-1748 & 2.68 & 2.82 & -- & 2.68 & -- & -- & -- \\
\hline TGU-1748 & 2.43 & 2.97 & 2.43 & 2.95 & -- & -- & -- \\
\hline TGU-1997 & 2.43 & 2.97 & 2.43 & 3.16 & 3.52 & 0.90 & 1.06 \\
\hline TGU-2148A ${ }^{1}$ & 2.42 & 2.97 & 2.38 & 3.32 & 3.57 & 0.90 & 1.06 \\
\hline
\end{tabular}
variously dated). Plateau tracer concentrations based on integrated sampling likely differ from the true cross-sectional average. Second, background concentrations of bromide were

Table 1-1. Summary of bromide concentrations, tracer-dilution estimates, and current-meter measurements used to develop final streamflow estimates, Toll Gate Creek, July-August 2007.

[TGH, Toll Gate Creek headwaters synoptic sampling reach; TGU, Toll Gate Creek upper synoptic sampling reach; TGM, Toll Gate Creek middle synoptic sampling reach; TGL, Toll Gate Creek lower synoptic sampling reach; $\mathrm{ft}^{3} / \mathrm{s}$, cubic feet per second; $\mathrm{mL} / \mathrm{min}$, milliliters per minute; $\mathrm{mg} / \mathrm{L}$, milligrams per liter; --, not applicable] 
Table 1-1. Summary of bromide concentrations, tracer-dilution estimates, and current-meter measurements used to develop final streamflow estimates, Toll Gate Creek, July-August 2007.-Continued

[TGH, Toll Gate Creek headwaters synoptic sampling reach; TGU, Toll Gate Creek upper synoptic sampling reach; TGM, Toll Gate Creek middle synoptic sampling reach; TGL, Toll Gate Creek lower synoptic sampling reach; $\mathrm{ft}^{3} / \mathrm{s}$, cubic feet per second; $\mathrm{mL} / \mathrm{min}$, milliliters per minute; $\mathrm{mg} / \mathrm{L}$, milligrams per liter; --, not applicable]

\begin{tabular}{|c|c|c|c|c|c|c|c|}
\hline Sample ID & $\begin{array}{c}\text { Final } \\
\text { streamflow } \\
\text { estimate } \\
\left(\mathrm{ft}^{3} / \mathrm{s}\right)\end{array}$ & $\begin{array}{c}\text { Alternative } \\
\text { streamflow } \\
\text { estimate } \\
\left(\mathrm{ft}^{3} / \mathrm{s}\right)\end{array}$ & $\begin{array}{c}\text { Tracer- } \\
\text { dilution } \\
\text { streamflow } \\
\text { estimate } \\
\left(\mathrm{ft}^{3} / \mathrm{s}\right)\end{array}$ & $\begin{array}{c}\text { Current- } \\
\text { meter } \\
\text { measurement } \\
\left(\mathrm{ft}^{3} / \mathrm{s}\right)\end{array}$ & $\begin{array}{c}\text { Synoptic } \\
\text { bromide } \\
\text { concentration } \\
\text { (mg/L) }\end{array}$ & $\begin{array}{c}\text { Presynoptic } \\
\text { bromide } \\
\text { concentration } \\
\text { (mg/L) }\end{array}$ & $\begin{array}{c}\text { Adjusted } \\
\text { presynoptic } \\
\text { bromide } \\
\text { concentration } \\
\text { (mg/L) }\end{array}$ \\
\hline TGU-2148B ${ }^{1}$ & 2.42 & 2.97 & 2.46 & 3.32 & 3.49 & 0.90 & 1.06 \\
\hline TGU-2346 & 2.39 & 2.97 & 2.39 & 2.92 & 3.72 & 1.03 & 1.22 \\
\hline TGU-2452 & 2.46 & 2.97 & 2.46 & 3.04 & 3.50 & 0.91 & 1.07 \\
\hline TGU-2708 & 2.64 & 2.97 & 2.64 & 2.65 & 3.36 & 0.93 & 1.10 \\
\hline TGU-2893 & 2.78 & 2.97 & 2.78 & 2.05 & 3.24 & 0.93 & 1.10 \\
\hline TGU-3114 & 2.92 & 2.97 & 2.92 & 2.98 & 3.14 & 0.93 & 1.10 \\
\hline TGU-3330 & 3.21 & 2.97 & 3.21 & -- & 2.95 & 0.92 & 1.09 \\
\hline TGU-3466 & 3.58 & 2.97 & 3.58 & 0.85 & 2.66 & 0.84 & 0.99 \\
\hline TGU-3627 & 3.48 & 2.97 & 3.48 & 4.77 & 2.83 & 0.94 & 1.11 \\
\hline TGU-3897 & 3.25 & 2.97 & 3.25 & 3.56 & 2.94 & 0.93 & 1.10 \\
\hline TGU-4086 & 3.05 & 2.97 & 3.05 & 2.97 & 2.94 & 0.83 & 0.98 \\
\hline TGU-4216A ${ }^{1}$ & 3.38 & 2.97 & 3.44 & 3.24 & 2.76 & 0.87 & 1.03 \\
\hline TGU-4216B' & 3.38 & 2.97 & 3.32 & 3.24 & 2.83 & 0.87 & 1.03 \\
\hline TGU-4361 & 3.50 & 2.97 & 3.50 & 2.83 & 2.66 & 0.81 & 0.96 \\
\hline TGU-4695 & 3.41 & 2.97 & 3.41 & 2.92 & 2.71 & 0.81 & 0.96 \\
\hline TGM-4361 & 4.81 & 4.89 & -- & 4.81 & -- & -- & -- \\
\hline TGM-4695A & 4.99 & 5.19 & -- & 4.99 & -- & -- & -- \\
\hline TGM-4695B & 4.99 & 5.19 & -- & 4.99 & -- & -- & -- \\
\hline TGM-4820 & 6.19 & 5.30 & -- & 6.19 & -- & -- & -- \\
\hline TGM-5075 & 4.75 & 5.54 & -- & 4.75 & -- & -- & -- \\
\hline TGM-5301 & 5.35 & 5.74 & -- & 5.35 & -- & -- & -- \\
\hline TGM-5617 & 6.29 & 6.03 & -- & 6.29 & -- & -- & -- \\
\hline TGM-5928 & 6.37 & 6.31 & -- & 6.37 & -- & -- & -- \\
\hline TGM-6111 & 7.19 & 6.48 & -- & 7.19 & -- & -- & -- \\
\hline TGM-6348 & 6.85 & 6.69 & -- & 6.85 & -- & -- & -- \\
\hline TGM-6531 & 6.66 & 6.86 & -- & 6.66 & -- & -- & -- \\
\hline TGM-6854 & 6.76 & 7.15 & -- & $7.00 ; 6.52$ & -- & -- & -- \\
\hline TGM-6982 & 6.62 & 7.27 & -- & 6.62 & -- & -- & -- \\
\hline TGM-7098 & 7.93 & 7.38 & -- & 7.93 & -- & -- & -- \\
\hline TGM-7214 & 7.66 & 7.48 & -- & 7.66 & -- & -- & -- \\
\hline TGM-7447 & 8.05 & 7.69 & -- & 8.05 & -- & -- & -- \\
\hline TGM-7818A & 8.27 & 8.03 & -- & 8.27 & -- & -- & -- \\
\hline TGM-7818B & 8.27 & 8.03 & -- & 8.27 & -- & -- & -- \\
\hline TGM-8011 & 8.20 & 8.21 & -- & -- & -- & -- & -- \\
\hline TGM-8281 & 8.13 & 8.45 & -- & 8.13 & -- & -- & -- \\
\hline TGL-8011 & 3.74 & 3.85 & -- & 3.74 & -- & -- & -- \\
\hline TGL-8281 & 3.32 & 4.05 & -- & 3.32 & -- & -- & -- \\
\hline TGL-8538 & 3.82 & 4.24 & -- & 3.82 & -- & -- & -- \\
\hline TGL-8794 & 5.12 & 4.43 & -- & 5.12 & -- & -- & -- \\
\hline TGL-9129 & 5.18 & 4.67 & -- & $5.38 ; 4.97$ & -- & -- & -- \\
\hline TGL-9408A & 4.26 & 4.88 & 4.37 & $4.63 ; 3.74$ & 2.58 & 0.908 & -- \\
\hline
\end{tabular}


Table 1-1. Summary of bromide concentrations, tracer-dilution estimates, and current-meter measurements used to develop final streamflow estimates, Toll Gate Creek, July-August 2007.-Continued

[TGH, Toll Gate Creek headwaters synoptic sampling reach; TGU, Toll Gate Creek upper synoptic sampling reach; TGM, Toll Gate Creek middle synoptic sampling reach; TGL, Toll Gate Creek lower synoptic sampling reach; $\mathrm{ft}^{3} / \mathrm{s}$, cubic feet per second; $\mathrm{mL} / \mathrm{min}$, milliliters per minute; $\mathrm{mg} / \mathrm{L}$, milligrams per liter; --, not applicable]

\begin{tabular}{|c|c|c|c|c|c|c|c|}
\hline Sample ID & $\begin{array}{c}\text { Final } \\
\text { streamflow } \\
\text { estimate } \\
\left(\mathrm{ft}^{3} / \mathbf{s}\right)\end{array}$ & $\begin{array}{c}\text { Alternative } \\
\text { streamflow } \\
\text { estimate } \\
\left(\mathrm{ft}^{3} / \mathrm{s}\right)\end{array}$ & $\begin{array}{c}\text { Tracer- } \\
\text { dilution } \\
\text { streamflow } \\
\text { estimate } \\
\left(\mathrm{ft}^{3} / \mathrm{s}\right)\end{array}$ & $\begin{array}{c}\text { Current- } \\
\text { meter } \\
\text { measurement } \\
\left(\mathrm{ft}^{3} / \mathbf{s}\right)\end{array}$ & $\begin{array}{c}\text { Synoptic } \\
\text { bromide } \\
\text { concentration } \\
\text { (mg/L) }\end{array}$ & $\begin{array}{c}\text { Presynoptic } \\
\text { bromide } \\
\text { concentration } \\
\text { (mg/L) }\end{array}$ & $\begin{array}{c}\text { Adjusted } \\
\text { presynoptic } \\
\text { bromide } \\
\text { concentration } \\
\text { (mg/L) }\end{array}$ \\
\hline TGL-9408B & 4.26 & 4.88 & 4.14 & $4.63 ; 3.74$ & 2.67 & 0.908 & -- \\
\hline TGL-9673 & 4.43 & 5.07 & 4.43 & $5.46 ; 5.51$ & 2.59 & 0.94 & -- \\
\hline TGL-9971 & 4.45 & 5.29 & 4.45 & & 2.54 & 0.901 & -- \\
\hline TGL-10236 & 4.86 & 5.48 & 4.86 & 5.39 & 2.38 & 0.877 & -- \\
\hline TGL-10497 & 5.11 & 5.67 & 5.11 & 6.37 & 2.29 & 0.857 & -- \\
\hline TGL-10716 & 5.41 & 5.83 & 5.41 & 5.95 & 2.23 & 0.878 & -- \\
\hline TGL-10993 & 5.94 & 6.04 & 5.94 & 5.03 & 2.16 & 0.928 & -- \\
\hline TGL-11228 & 6.92 & 6.21 & 6.92 & 6.76 & 1.97 & 0.918 & -- \\
\hline TGL-11312 & 7.18 & 6.27 & 7.18 & 6.1 & 1.96 & 0.941 & -- \\
\hline TGL-11473A & 7.47 & 6.39 & 7.68 & 6.25 & 1.89 & 0.94 & -- \\
\hline TGL-11473B & 7.47 & 6.39 & 7.26 & 6.25 & 1.95 & 0.94 & -- \\
\hline TGL-11835 & 6.73 & 6.65 & 6.73 & 6.76 & 2.01 & 0.929 & -- \\
\hline TGL-12164 & 6.53 & 6.89 & 3.88 & 6.53 & 2.80 & 0.917 & -- \\
\hline
\end{tabular}

${ }^{1}$ Replicate sample. Final streamflow estimate is set equal to the average of the two tracer-dilution streamflow estimastes.

Table 1-2. Summary of hydrologic and tracer-injection information used to determine streamflow estimates and interpret results, Toll Gate Creek, July-August 2007.

[TGH, Toll Gate Creek headwaters synoptic sampling reach; TGU, Toll Gate Creek upper synoptic sampling reach; TGM, Toll Gate Creek middle synoptic sampling reach; TGL, Toll Gate Creek lower synoptic sampling reach; Rainfall, gage, rainfall recorded at 6th Avenue rain gage; Rainfall, noted, rainfall as noted by U.S. Geological Survey personnel; $\mathrm{mL} / \mathrm{min}$, milliliters per minute; $\mathrm{mg} / \mathrm{L}$, milligrams per liter; --, not applicable]

\begin{tabular}{|c|c|c|c|c|c|c|}
\hline $\begin{array}{l}\text { Synoptic } \\
\text { sampling } \\
\text { reach }\end{array}$ & $\begin{array}{l}\text { Synoptic } \\
\text { sampling } \\
\text { date }\end{array}$ & $\begin{array}{l}\text { Rainfall, gage, } \\
\text { in inches }\end{array}$ & Rainfall, noted & $\begin{array}{l}\text { Injection } \\
\text { start date }\end{array}$ & $\begin{array}{l}\text { Injection } \\
\text { rate } \\
\text { (mL/min) }\end{array}$ & $\begin{array}{c}\text { Injection } \\
\text { concentration } \\
(\mathrm{mg} / \mathrm{L})\end{array}$ \\
\hline TGH & 08/01/07 & 0.08 on $07 / 30 / 07$ & $\begin{array}{l}\text { Rain at Delaney Farm at } 1800 \\
\text { hours on } 07 / 30 / 07\end{array}$ & -- & -- & -- \\
\hline TGU & $08 / 02 / 07$ & 0.08 on $07 / 30 / 07$ & $\begin{array}{l}\text { Rain at Delaney Farm at } 1800 \\
\text { hours on } 07 / 30 / 07\end{array}$ & 07/30/07 & 60 & 168,210 \\
\hline TGM & $07 / 29 / 07$ & $\begin{array}{l}0.12 \text { on } 07 / 27 / 07 \\
0.08 \text { on } 07 / 28 / 07\end{array}$ & $\begin{array}{l}\text { Rain the night of } 07 / 26 / 07 \\
\text { and(or) early morning of } \\
07 / 27 / 07 \text {; heavy rain the } \\
\text { night of } 07 / 27 / 07 \text { and(or) } \\
\text { early morning of } 07 / 28 / 07\end{array}$ & $07 / 27 / 07$ & -- & -- \\
\hline TGL & $07 / 26 / 07$ & none recorded & $\begin{array}{l}\text { Rain the night of } 07 / 25 / 07 \\
\text { and(or) early morning of } \\
07 / 26 / 07 \text {; flow from some } \\
\text { of the inflows was notice- } \\
\text { ably higher on } 07 / 26 / 07 \\
\text { than on the previous days }\end{array}$ & $07 / 24 / 07$ & 71 & 175,360 \\
\hline
\end{tabular}


about $1 \mathrm{mg} / \mathrm{L}$ and spatially nonuniform, as documented by presynoptic sampling. The tracer-dilution method accounts for these background concentrations by correcting the plateau concentration for background $\left(C-C_{p}\right.$, equation 1-1). This correction is made under the assumption that background conditions during synoptic sampling are identical to those documented by the presynoptic samples. For Toll Gate Creek, small rainfall events occurred between the presynoptic and synoptic sampling periods (table 1-2), such that this assumption was violated (samples collected immediately above each injection point indicate that rainfall diluted the background bromide concentrations by as much as 50 percent; presynoptic concentrations are therefore an overestimate of the background bromide concentration that was entering the stream on the day of synoptic sampling).

In addition to the complications noted above, spatial profiles of streamflow from current-meter measurements and the tracer-dilution method were adversely affected by the temporal variation in streamflow that was caused by the rainfall events. Under steady-flow conditions, the change in streamflow between two stream sampling locations reflects the effects of inflows and (or) outflows. This interpretation is invalid for the case of temporal variation (unsteady flow), as the change in streamflow between two sites not only reflects the net effects of inflow and (or) outflow, but also the timing of the measurements and sampling.

Additional flow information during the study period is available from the 6th Avenue stream gage (U.S. Geological Survey stream-gaging station 394329104490101 ) located just upstream from 6th Avenue, near the end of the TGM subreach (fig. 4 in report main body). Streamflow values from this gage prior to 2012 are known to overestimate streamflow under some low-flow conditions. A current-meter measurement on July 3, 2007 of 2.25 cubic feet per second $\left(\mathrm{ft}^{3} / \mathrm{s}\right)$ was made at a time when the gage indicated $20.1 \mathrm{ft}^{3} / \mathrm{s}$, for example. Despite this overestimation, stage-height data from the stream gage provides qualitative information on the effects of rainfall and the hydrologic setting.

\section{Final Streamflow Estimates}

Given the numerous complications in estimating streamflow noted above, development of streamflow profiles for use in the synoptic mass-balance approach is a subjective exercise. The subsections that follow document the development of the final streamflow profiles that are used to calculate the constituent loads presented in the main body of this report. Additional details are provided in table $1-1$.

\section{Toll Gate Headwaters (TGH)}

Streamflow estimates for the TGH subreach are based entirely on current-meter measurements. The tracer-dilution method was not attempted in the TGH subreach because of shallow depths and low flow in the wetland reach and the concrete-lined channel. Rain prior to the synoptic sampling caused a peak in streamflow at the 6th Avenue stream gage on the night of July 30, 2007. As of synoptic day (August 1, 2007), the flow was likely receding within the study reach [see Toll Gate Upper (TGU) section, Appendix 1, and results presented in the main body of the text].

The final streamflow profile for the TGH subreach downstream from Buckley Road is based on current-meter measurements conducted at the time of synoptic sampling (table 1-1). The current-meter measurement at TGH-0 appears to be erroneously high; the final streamflow estimate for TGH-0 was therefore set equal to the current-meter measurement from the next downstream site (TGH-371).

\section{Toll Gate Upper (TGU)}

Estimates of streamflow for sampling locations within the TGU subreach are available from both current-meter measurements and the tracer-dilution method. Rain prior to the day of synoptic sampling caused a peak in streamflow at the 6th Avenue stream gage on the night of July 30, 2007. As of synoptic day (August 2, 2007), the flow was still receding within the study reach, as documented by the increasing bromide concentrations at the transport sites ${ }^{1}$ (increased streamflow caused by rainfall initially diluted the instream bromide concentrations; instream bromide concentrations then increased as streamflow receded). As a result, all sites were sampled as the flow was receding. The effects of rain were thus similar to those observed for the TGM subreach [see Toll Gate Middle (TGM), Appendix 1], although less pronounced.

The final streamflow profile for the TGU subreach is based on tracer-dilution estimates provided by equation 1-1, where the presynoptic bromide concentration $\left(C_{p}\right)$ was set equal to the adjusted presynoptic bromide concentration (table 1-1). The adjusted presynoptic concentrations were developed by shifting the presynoptic concentration profile upward to align with bromide concentration observed above the injection point. This adjustment resulted in tracer-dilution estimates that were in general agreement with the current-meter measurements (table 1-1).

\section{Toll Gate Middle (TGM)}

Streamflow estimates for the TGM subreach are based entirely on current-meter measurements; tracer-dilution estimates of streamflow were not considered because of the effects of rainfall on background bromide concentrations (presynoptic bromide concentrations do not reflect bromide concentrations that were entering the stream on the day of synoptic sampling; see discussion of rainfall and pre-synoptic sampling in the "General Methodology" section, Appendix 1).

Rain prior to the day of synoptic sampling caused a peak in streamflow at the downstream end of the study reach on July 28, 2007. As a result, all sites were sampled as the flow

\footnotetext{
${ }^{1}$ Transport sites are the subset of stream sites that are sampled over time to document the presence or absence of a steady-state tracer plateau.
} 
was receding on July 29, 2007. Increased flows from rainfall had a pronounced effect on observed background bromide concentrations above the injection point and specific conductance (as measured by an instream sonde located near the end of the subreach). The effect of rainfall on the TGM subreach is greater than the rainfall effects noted for the TGU and TGL synoptics, as documented by the dilution of the bromide concentration above each injection point and a comparison of current-meter measurements for the three subreaches.

The final streamflow profile for the TGM subreach is based on current-meter measurements made at the time of synoptic sampling (table 1-1). A current-meter measurement was not made at TGM-8011; streamflow at TGM-8011 was therefore set equal to the average of the current-meter measurements at the neighboring sites (table 1-1).

\section{Toll Gate Lower (TGL)}

Rainfall immediately preceding the TGL synoptic sampling period (table 1-2) resulted in a wave of increased streamflow that was moving downstream as the synoptic sampling team was moving upstream on July 26, 2007. The effect of rainfall therefore depends on the sampling site location. Stream sites upstream from (and including) TGL-10497 were sampled during the receding part of the streamflow profile; sites in the vicinity of TGL-11312 were sampled during peak streamflow; and site TGL-12164 was sampled before the peak arrived.

The final streamflow profile for the TGL subreach is based on a combination of current-meter measurements and estimates provided by the tracer-dilution method (table 1-1).
Final streamflow estimates for stream sites upstream from the injection point (TGL-8011 to TGL-9129) are set equal to the current-meter measurements, whereas estimates for sites downstream from the injection point (TGL-9673 to TGL-11835) are equal to the tracer-dilution estimates provided by equation 1-1. For site TGL-12164, the tracer-dilution estimate of streamflow appears to be too low, and streamflow was therefore set equal to the current-meter measurement.

\section{Alternative Streamflow Estimates}

Given the complicating factors associated with currentmeter measurements and the tracer-dilution estimates noted above, there is a high degree of uncertainty in the final streamflow profile. An alternative method of developing the profile was therefore implemented in which the spatial trends in the current-meter measurements were determined by linear regression (Helsel and Hirsch, 2002) and used to estimate streamflow (table 1-3). This method assumes that the current-meter measurements are subject to random errors which cause some measurements to be erroneously high, while some are erroneously low. The trend-based approach therefore takes the noise out of the current-meter data. The approach is appropriate because Toll Gate Creek gains water steadily rather than abruptly (there are no major tributary inflows). Alternative streamflow estimates and profiles for the TGH, TGU, TGM, and TGL subreaches are presented in table $1-1$ and on figure $1-1$. The linear regression equations are presented in table $1-3$.

Table 1-3. Development of alternative streamflow estimates, Toll Gate Creek, July-August 2007.

[TGH, Toll Gate Creek headwaters synoptic sampling reach; TGU, Toll Gate Creek upper synoptic sampling reach; TGM, Toll Gate Creek middle synoptic sampling reach; TGL, Toll Gate Creek lower synoptic sampling reach; Q, discharge in cubic feet per second; r; linear correlation coefficient; distance in meters; distance along reach downstream from Quincy Reservoir; <, less than]

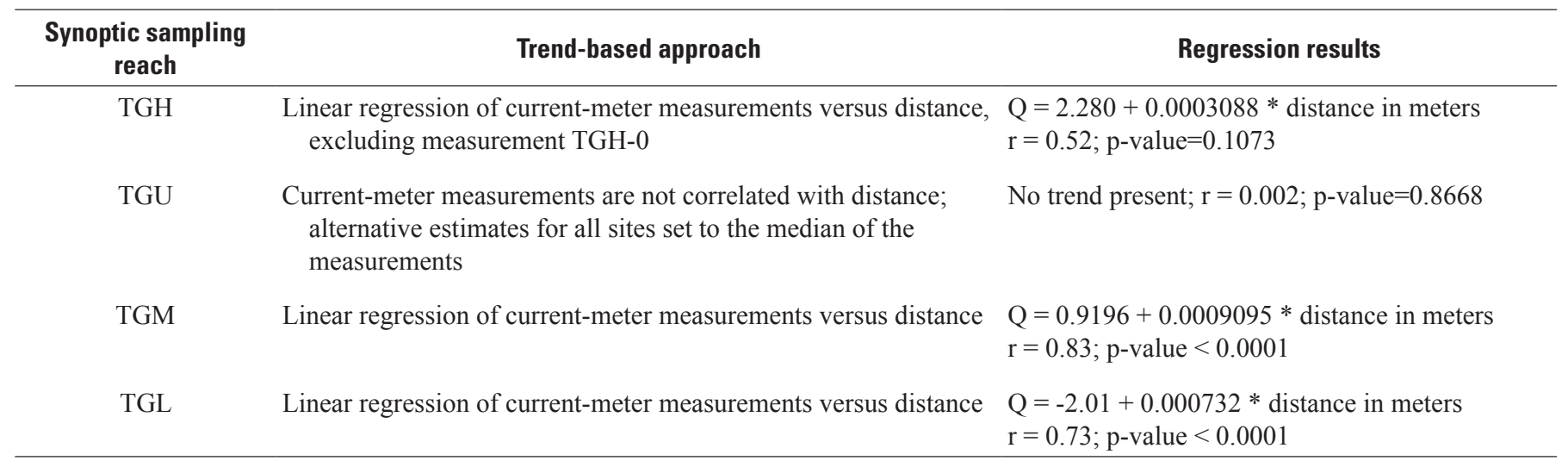




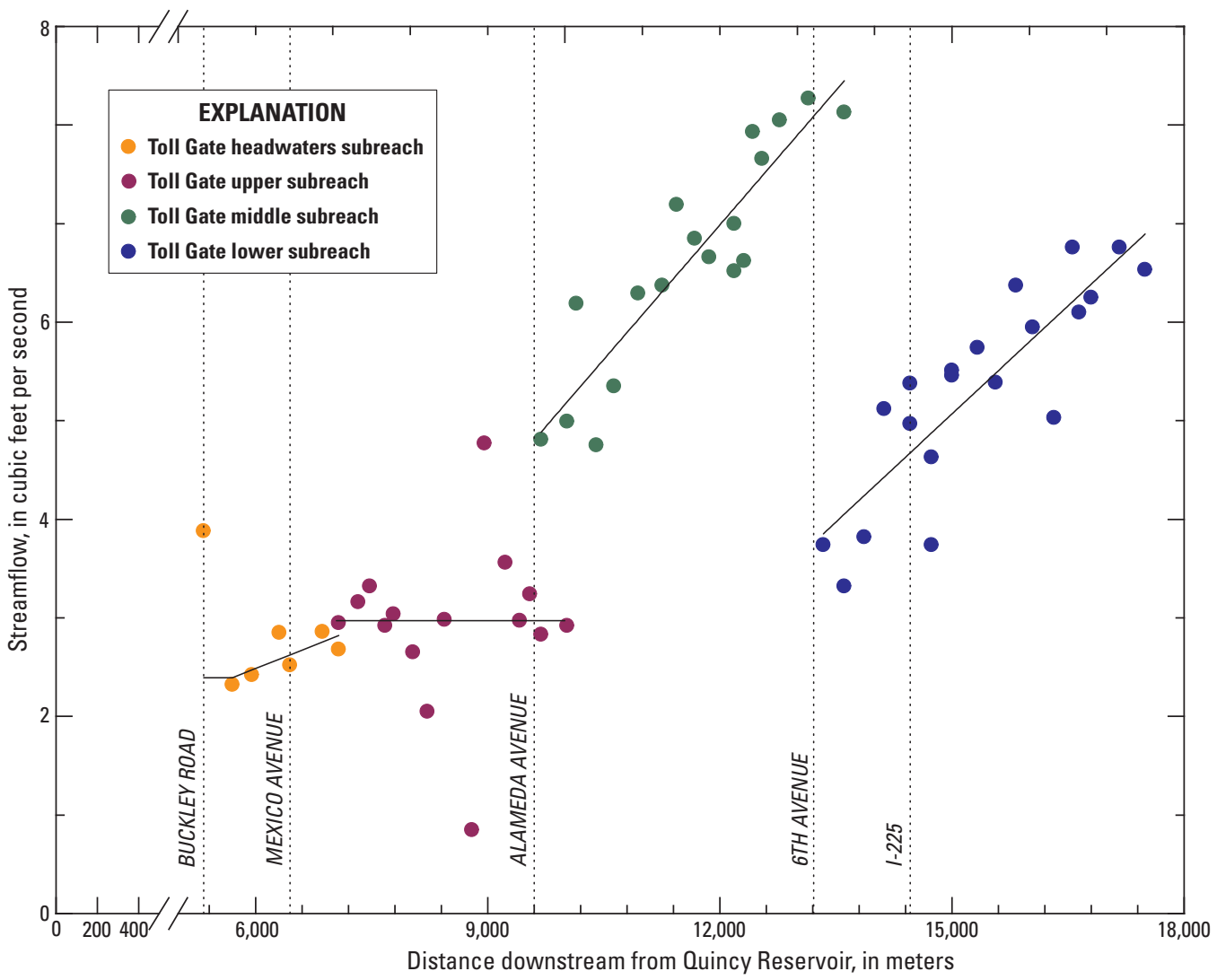

Figure 1-1. Graph showing acoustic Doppler Velocity meter streamflow measurements and linear regression lines for alternative streamflow estimates, Toll Gate Creek, July-August 2007 (Regression lines defined in table 1-3).

\section{Summary of Streamflow Results}

The foregoing analysis of streamflow estimates for the TGH, TGU, TGM, and TGL subreaches is summarized as follows:

- Despite the issues described above, current-meter and tracer-dilution estimates of streamflow are generally consistent. The streamflow profile from the tracer-dilution estimates is generally 'smoother' than from the currentmeter measurements, and the current-meter measurements appear to be more prone to error. Tracer-dilution estimates of streamflow are therefore used whenever possible.

- A dry period preceded the primary sampling period; no rainfall was recorded at the 6th Avenue stream gage from July 19 through July 26, 2007. This dry period was followed by a series of small rainfall events from July 27 through August 1, 2007 that affected the synoptic sampling results. The effects of rainfall were documented by dilution of the tracer at transport sites, stage data from the 6th Avenue stream gage and pressure transducers, and the dilution of specific conductance as measured by an instream sonde. Because of the rainfall, each synoptic sampling event does not represent steady-state conditions. Despite this result, the loading results presented in the main body of this report provide a general profile of loading in which constituent loads increase steadily with distance. 


\section{Appendix 2. Analytical Quality-Assurance and Quality-Control Data and Results for Toll Gate Creek Surface-Water and Groundwater Samples, 2007}

This appendix documents analytical quality-assurance and quality-control (QA/QC) samples (blanks, replicates, and standard-reference samples) collected during the July-August 2007 period of study and discusses QA/QC results.

\section{Effects of Sample Processing on Environmental Sample Results}

The effects of sampling equipment and cleaning procedures on environmental sample results were evaluated by collecting field and equipment blanks during environmental sampling. To avoid cross contamination between sites, equipment used for surface-water and groundwater sampling was cleaned between field sites using the procedures described by Wilde (2004). Field blanks are samples of laboratoryprepared deionized water (DIW) that are transported to the field and used to rinse field equipment after cleaning. The DIW rinsate is then collected in sample bottles and submitted to the laboratory for analysis. An equipment blank is the same as a field blank but is collected prior to any groundwater sampling to evaluate potential effects of the sampling equipment on laboratory results. A source-solution blank is DIW poured directly from the laboratory container into sample bottles, and is used to evaluate constituent concentrations in the DIW source solution separate from the effects of sample processing. One surface-water field blank was collected on each synoptic-sampling day, and three field blanks and two equipment blanks were collected during groundwater sampling. In addition, two source-solution blanks were processed and analyzed during field activities, and one sample of nitricacid preservative was processed and analyzed to determine constituent concentrations in the nitric acid used as a surfacewater sample preservative.

Average blank concentrations for each constituent are compared to the respective reporting levels for surface-water (table 2-1) and groundwater (table 2-2) samples. For blank samples with constituent concentrations greater than their respective reporting level, constituent concentrations in the blank also are compared to the minimum concentration of the environmental samples. Constituents detected above their reporting levels in blank samples include aluminum (filtered and unfiltered surface-water blanks), calcium (filtered and unfiltered surface-water and filtered groundwater blanks), dissolved organic carbon (filtered groundwater blank), magnesium (unfiltered surface-water and filtered groundwater blanks), manganese (filtered groundwater blanks), silica (filtered surface-water and filtered groundwater blanks), and zinc (filtered surface-water and filtered groundwater blanks). Of the constituents detected in blank samples, calcium, dissolved organic carbon, magnesium, manganese, and silica concentrations in blanks are several times less than the minimum concentration in the environmental samples such that sample processing caused negligible effects on concentrations of these constituents in environmental samples. Selenium, the primary constituent of concern in this study, was not detected above its reporting level of $0.08 \mu \mathrm{g} / \mathrm{L}$ in surface-water or groundwater blanks indicating sample processing did not contaminate environmental samples with selenium.

Aluminum concentrations for filtered and unfiltered surface-water blanks and zinc concentrations for filtered surface-water blanks and filtered groundwater blanks were greater than their respective reporting levels and were on the same order of magnitude or greater than the minimum environmental sample concentration (tables 2-1 and 2-2). Aluminum was detected in all filtered and unfiltered surfacewater field blanks (table 2-1). In filtered field blanks, detected aluminum concentrations ranged from ${ }^{2} 1.2 \mathrm{E} \mu \mathrm{g} / \mathrm{L}$ to $27.7 \mu \mathrm{g} / \mathrm{L}$ and the minimum environmental sample concentration was $0.80 \mu \mathrm{g} / \mathrm{L}$. Aluminum concentrations in unfiltered field blanks ranged from ${ }^{2} 2 \mathrm{E} \mu \mathrm{g} / \mathrm{L}$ to $49 \mu \mathrm{g} / \mathrm{L}$ and the minimum environmental sample concentration was $4.0 \mu \mathrm{g} / \mathrm{L}$. Aluminum was not detected above reporting levels in either the filtered or unfiltered source-solution blank. These results indicate aluminum concentration results for surface-water samples are possibly affected by sample collection and processing procedures. Zinc was detected in filtered surface-water field blanks and filtered groundwater field blanks but was not detected above reporting levels in source-solution blanks. The maximum zinc concentration in filtered surface-water field blanks was $0.85 \mu \mathrm{g} / \mathrm{L}$, which is slightly greater than the reporting level of $0.60 \mu \mathrm{g} / \mathrm{L}$ and slightly greater than the minimum environmental sample concentration of $0.43 \mu \mathrm{g} / \mathrm{L}$ (table 2-1). Environmental samples having zinc concentrations less than $1-2 \mu \mathrm{g} / \mathrm{L}$ are likely affected by zinc contamination introduced during sample processing and analysis. Zinc concentrations detected in the filtered groundwater field blanks ranged from 1.2 to $4.9 \mu \mathrm{g} / \mathrm{L}$, and are within the range of groundwater sample concentrations $(0.72-7.3 \mu \mathrm{g} / \mathrm{L}$; table $2-2)$. These results indicate that the equipment used for groundwater sampling (most likely the pump used during filtering) may have contributed dissolved zinc to the groundwater samples.

\footnotetext{
${ }^{2} \mathrm{E}$, estimated value less than the reporting level and greater than the detection level.
} 
Table 2-1. Analytical quality-assurance and quality-control data for surface-water sampling blanks, Toll Gate Creek, July-August 2007.

[Sample ID, synoptic-sample identification number; E, estimated value less than the reporting level and greater than the detection level; <, less than; mg/L, milligrams per liter; $\mu \mathrm{g} / \mathrm{L}$, micrograms per liter; --, no data]

\begin{tabular}{|c|c|c|c|c|c|c|c|c|c|c|c|c|}
\hline Sample ID & Blank purpose & $\begin{array}{c}\text { Alkalinity, } \\
\text { (mg/L CaCO })\end{array}$ & $\begin{array}{c}\text { Aluminum, } \\
\text { filtered } \\
(\mu \mathrm{g} / \mathrm{L})\end{array}$ & $\begin{array}{c}\text { Aluminum, } \\
\text { unfiltered } \\
(\mu \mathrm{g} / \mathrm{L})\end{array}$ & $\begin{array}{c}\text { Bromide, } \\
\text { filtered } \\
\text { (mg/L) }\end{array}$ & $\begin{array}{l}\text { Calcium, } \\
\text { filtered } \\
\text { (mg/L) }\end{array}$ & $\begin{array}{c}\text { Calcium, } \\
\text { unfiltered } \\
\text { (mg/L) }\end{array}$ & $\begin{array}{c}\text { Chloride, } \\
\text { filtered } \\
\text { (mg/L) }\end{array}$ & $\begin{array}{c}\text { Iron, } \\
\text { filtered } \\
\text { ( } \mu \mathrm{g} / \mathrm{L})\end{array}$ & $\begin{array}{c}\text { Iron, } \\
\text { unfiltered } \\
(\mu \mathrm{g} / \mathrm{L})\end{array}$ & $\begin{array}{c}\text { Fluoride, } \\
\text { filtered } \\
\text { (mg/L) }\end{array}$ & $\begin{array}{c}\text { Magnesium, } \\
\text { filtered } \\
\text { (mg/L) }\end{array}$ \\
\hline TG-10176 & Source solution blank & $<5$ & $<1.6$ & $<2$ & $<0.02$ & $0.01 \mathrm{E}$ & $0.01 \mathrm{E}$ & $<0.12$ & $<6$ & $<6$ & $<0.1$ & $<0.014$ \\
\hline TG-10176 & Nitric acid blank & -- & -- & 44 & -- & -- & 0.13 & -- & -- & $<6$ & -- & -- \\
\hline TG-10176 & Field blank & $<5$ & 27.7 & 49 & $<0.02$ & 0.08 & 0.13 & $<0.12$ & $<6$ & $<6$ & $<0.1$ & $<0.014$ \\
\hline TG-6111 & Field blank & $<5$ & 17.8 & 27 & $<0.02$ & 0.1 & 0.11 & $<0.12$ & $<6$ & $<6$ & $0.06 \mathrm{E}$ & $0.011 \mathrm{E}$ \\
\hline TG-0 & Field blank & $<5$ & 7.2 & 12 & $<0.02$ & 0.04 & 0.04 & $<0.12$ & $<6$ & $<6$ & $<0.1$ & $<0.014$ \\
\hline TG-2983 & Field blank & $<5$ & $1.2 \mathrm{E}$ & $2 \mathrm{E}$ & $<0.02$ & 0.02 & 0.02 & $<0.12$ & $<6$ & $<6$ & $<0.1$ & $<0.014$ \\
\hline \multicolumn{2}{|l|}{ Reporting level } & 5 & 1.6 & 2 & 0.02 & 0.02 & 0.014 & 0.12 & 6 & 6 & 0.1 & 0.014 \\
\hline \multicolumn{2}{|c|}{ Average blank concentration } & $<5$ & 13.5 & 22.5 & $<0.02$ & 0.06 & 0.075 & $<0.12$ & $<6$ & $<6$ & $<0.1$ & 0.013 \\
\hline \multicolumn{2}{|c|}{ Minimum blank concentration } & $<5$ & $<1.6$ & $<2$ & $<0.02$ & $0.01 \mathrm{E}$ & $0.01 \mathrm{E}$ & $<0.12$ & $<6$ & $<6$ & $<0.1$ & $<0.014$ \\
\hline \multicolumn{2}{|c|}{ Maximum blank concentration } & $<5$ & 27.7 & 49 & $<0.02$ & 0.1 & 0.13 & $<0.12$ & $<6$ & $<6$ & $0.06 \mathrm{E}$ & $0.011 \mathrm{E}$ \\
\hline \multicolumn{2}{|c|}{ Minimum environmental sample concentration } & 75 & 0.8 & 4.0 & 0.09 & 53.5 & 54.5 & 37.1 & 9 & 12 & 0.36 & 10.1 \\
\hline \multicolumn{2}{|c|}{ Maximum environmental sample concentration } & 447 & 172 & 840 & 3.1 & 398 & 598 & 395 & 241 & 2,010 & 1 & 85 \\
\hline
\end{tabular}

Table 2-1. Analytical quality-assurance and quality-control data for surface-water sampling blanks, Toll Gate Creek, July-August 2007.—Continued

[Sample ID, synoptic-sample identification number; E, estimated value less than the reporting level and greater than the detection level; <, less than; mg/L, milligrams per liter; $\mu \mathrm{g} / \mathrm{L}$, micrograms per liter; --, no data]

\begin{tabular}{|c|c|c|c|c|c|c|c|c|c|c|c|}
\hline Sample ID & Blank purpose & $\begin{array}{c}\text { Magnesium, } \\
\text { unfiltered } \\
\text { (mg/L) }\end{array}$ & $\begin{array}{c}\text { Manganese, } \\
\text { filtered } \\
(\mu \mathrm{g} / \mathrm{L})\end{array}$ & $\begin{array}{c}\text { Manganese, } \\
\text { unfiltered } \\
\text { ( } \mu \mathrm{g} / \mathrm{L})\end{array}$ & $\begin{array}{l}\text { Sodium, } \\
\text { filtered } \\
\text { (mg/L) }\end{array}$ & $\begin{array}{c}\text { Sodium, } \\
\text { unfiltered } \\
\text { (mg/L) }\end{array}$ & $\begin{array}{l}\text { Selenium, } \\
\text { filtered } \\
\text { ( } \mu \mathrm{g} / \mathrm{L})\end{array}$ & $\begin{array}{c}\text { Selenium, } \\
\text { unfiltered } \\
(\mu \mathrm{g} / \mathrm{L})\end{array}$ & $\begin{array}{c}\text { Silica, } \\
\text { filtered } \\
\text { (mg/L) }\end{array}$ & $\begin{array}{l}\text { Sulfate, } \\
\text { filtered } \\
\text { (mg/L) }\end{array}$ & $\begin{array}{c}\text { Total } \\
\text { dissolved } \\
\text { solids, filtered } \\
\text { (mg/L) }\end{array}$ \\
\hline TG-10176 & Source solution blank & $<0.002$ & $<0.2$ & $<0.4$ & $<0.2$ & $<0.5$ & $<0.08$ & 0.08 & 0.04 & $<0.18$ & $<10$ \\
\hline TG-10176 & Nitric acid blank & 0.003 & -- & $<0.4$ & & $<0.5$ & -- & 0.08 & -- & -- & -- \\
\hline TG-10176 & Field blank & 0.006 & $<0.2$ & $0.3 \mathrm{E}$ & $<0.2$ & $<0.5$ & $<0.08$ & 0.08 & 0.05 & $<0.18$ & $<10$ \\
\hline TG-6111 & Field blank & 0.008 & 0.2 & $0.3 \mathrm{E}$ & $<0.2$ & $<0.5$ & $<0.08$ & 0.08 & $0.01 \mathrm{E}$ & $0.09 \mathrm{E}$ & $<10$ \\
\hline TG-0 & Field blank & $0.002 \mathrm{E}$ & $<0.2$ & $<0.4$ & $<0.2$ & $<0.5$ & $<0.08$ & 0.08 & $<0.02$ & $<0.18$ & $<10$ \\
\hline TG-2983 & Field blank & 0.002 & $<0.2$ & $0.4 \mathrm{E}$ & $<0.2$ & $<0.5$ & $<0.08$ & 0.08 & $<0.02$ & $<0.18$ & 14 \\
\hline \multicolumn{2}{|l|}{ Reporting level } & 0.002 & 0.2 & 0.4 & 0.2 & 0.5 & 0.08 & 0.08 & 0.018 & 0.18 & 10 \\
\hline \multicolumn{2}{|c|}{ Average blank concentration } & 0.005 & 0.2 & 0.4 & $<0.2$ & $<0.5$ & $<0.08$ & 0.08 & 0.03 & 0.16 & 11 \\
\hline \multicolumn{2}{|c|}{ Minimum blank concentration } & $<0.002$ & $<0.2$ & $<0.4$ & $<0.2$ & $<0.5$ & $<0.08$ & 0.08 & $<0.02$ & $<0.18$ & $<10$ \\
\hline \multicolumn{2}{|c|}{ Maximum blank concentration } & 0.008 & 0.2 & $0.4 \mathrm{E}$ & $<0.2$ & $<0.5$ & $<0.08$ & 0.08 & 0.05 & 0.18 & 14 \\
\hline \multicolumn{2}{|c|}{ Minimum environmental sample concentration } & 10 & 2.5 & 2.7 & 50.5 & 47.3 & 0.4 & 0.39 & 8.42 & 41.4 & 472 \\
\hline \multicolumn{2}{|c|}{ Maximum environmental sample concentration } & 119 & 1,440 & 1,540 & 683 & 693 & 79 & 68 & 38 & 2,230 & 3,930 \\
\hline
\end{tabular}


Table 2-1. Analytical quality-assurance and quality-control data for surface-water sampling blanks, Toll Gate Creek, July-August 2007.-Continued

[Sample ID, synoptic-sample identification number; E, estimated value less than the reporting level and greater than the detection level; <, less than; $\mathrm{mg} / \mathrm{L}$, milligrams per liter; $\mu \mathrm{g} / \mathrm{L}$, micrograms per liter; --, no data]

\begin{tabular}{lccccc}
\hline \multicolumn{1}{c}{ Sample ID } & \multicolumn{1}{c}{ Blank purpose } & $\begin{array}{c}\text { Uranium, } \\
\text { filtered } \\
(\boldsymbol{\mu g} / \mathbf{L})\end{array}$ & $\begin{array}{c}\text { Uranium, } \\
\mathbf{u n f i l t e r e d} \\
(\boldsymbol{\mu} \mathbf{g} / \mathbf{L})\end{array}$ & $\begin{array}{c}\text { Zinc, } \\
\text { filtered } \\
(\boldsymbol{\mu} \mathbf{g} / \mathbf{L})\end{array}$ & $\begin{array}{c}\text { Zinc, } \\
\mathbf{u n f i l t e r} \\
(\boldsymbol{\mu} \mathbf{g} / \mathbf{L})\end{array}$ \\
\hline TG-10176 & Source solution blank & $<0.04$ & $<0.012$ & $<0.6$ & $<2$ \\
TG-10176 & Nitric acid blank & -- & $<0.012$ & -- & $<2$ \\
TG-10176 & Field blank & $<0.04$ & $<0.012$ & 0.6 & $<2$ \\
TG-6111 & Field blank & $<0.04$ & $<0.012$ & $<0.6$ & $<2$ \\
TG-0 & Field blank & $<0.04$ & $<0.012$ & $0.37 \mathrm{E}$ & $<2$ \\
TG-2983 & Field blank & $<0.04$ & $<0.012$ & 0.85 & $<2$ \\
Reporting level & & 0.04 & 0.012 & 0.6 & 2 \\
Average blank concentration & $<0.04$ & $<0.012$ & 0.61 & $<2$ \\
Minimum blank concentration & $<0.04$ & $<0.012$ & 0.37 & $<2$ \\
Maximum blank concentration & $<0.04$ & $<0.012$ & 0.85 & $<2$ \\
Minimum environmental sample concentration & 1.6 & 1.6 & 0.43 & 1.03 \\
Maximum environmental sample concentration & 82 & 79 & 63 & 55 \\
\hline
\end{tabular}

Table 2-2. Analytical quality-assurance and quality-control data for groundwater sampling blanks, Toll Gate Creek, July-August 2007.

[Sample ID, synoptic-sample identification number; E, estimated value less than the reporting level and greater than the detection level; <, less than; mg/L, milligramsper liter; $\mu \mathrm{g} / \mathrm{L}$, micrograms per liter; ,-- no data]

\begin{tabular}{|c|c|c|c|c|c|c|c|c|c|}
\hline Sample ID & Blank purpose & $\begin{array}{l}\text { Aluminum, } \\
\text { filtered } \\
(\mu \mathrm{g} / \mathrm{L})\end{array}$ & $\begin{array}{c}\text { Bromide, } \\
\text { filtered } \\
\text { (mg/L) }\end{array}$ & $\begin{array}{c}\text { Calcium, } \\
\text { filtered } \\
\text { (mg/L) }\end{array}$ & $\begin{array}{l}\text { Chloride, } \\
\text { filtered } \\
\text { (mg/L) }\end{array}$ & $\begin{array}{c}\text { Dissolved } \\
\text { organic carbon, } \\
\text { filtered } \\
\text { (mg/L) }\end{array}$ & $\begin{array}{l}\text { Iron, } \\
\text { filtered } \\
\text { ( } \mu \mathrm{g} / \mathrm{L})\end{array}$ & $\begin{array}{l}\text { Fluoride, } \\
\text { filtered } \\
\text { (mg/L) }\end{array}$ & $\begin{array}{c}\text { Potassium, } \\
\text { filtered } \\
\text { (mg/L) }\end{array}$ \\
\hline URLUS-30 & Equipment blank & $1.6 \mathrm{E}$ & $<0.02$ & 0.18 & $<0.12$ & $<0.4$ & $<6$ & $<0.1$ & $<0.04$ \\
\hline URLUS-30 & Source solution blank & $<1.6$ & $<0.02$ & $<0.02$ & $<0.12$ & $<0.4$ & $<6$ & $<0.1$ & $<0.04$ \\
\hline URLUS-18 & Equipment blank & $<1.6$ & $<0.02$ & $<0.02$ & $<0.12$ & $<0.4$ & $<6$ & 0.1 & $<0.04$ \\
\hline SCTC-5 & Field blank & $<1.6$ & $<0.02$ & 0.04 & $<0.12$ & $<0.4$ & $<6$ & $<0.1$ & $<0.04$ \\
\hline WT-2 & Field blank & $<1.6$ & $<0.02$ & $<0.02$ & $<0.12$ & $<0.4$ & $<6$ & $<0.1$ & $<0.04$ \\
\hline WT-8 & Field blank & $<1.6$ & $<0.02$ & 0.1 & $<0.12$ & 0.9 & $<6$ & $<0.1$ & $<0.04$ \\
\hline \multicolumn{2}{|c|}{ Reporting level } & 1.6 & 0.02 & 0.02 & 0.12 & 0.4 & 6 & 0.1 & 0.04 \\
\hline \multicolumn{2}{|c|}{ Average blank concentration } & $<1.6$ & $<0.02$ & 0.06 & $<0.12$ & 0.5 & $<6$ & $<0.1$ & $<0.04$ \\
\hline \multicolumn{2}{|c|}{ Minimum blank concentration } & $<1.6$ & $<0.02$ & $<0.02$ & $<0.12$ & $<0.4$ & $<6$ & $<0.1$ & $<0.04$ \\
\hline \multicolumn{2}{|c|}{ Maximum blank concentration } & $1.6 \mathrm{E}$ & $<0.02$ & 0.18 & $<0.12$ & 0.9 & $<6$ & 0.1 & $<0.04$ \\
\hline \multicolumn{2}{|c|}{ Minimum environmental sample concentration } & 0.9 & 0.34 & 93.6 & 72.9 & 1.7 & 3 & 0.14 & 0.79 \\
\hline \multicolumn{2}{|c|}{ Maximum environmental sample concentration } & 150 & 4.8 & 631 & 308 & 9.9 & 30 & 1.6 & 7.9 \\
\hline
\end{tabular}


Table 2-2. Analytical quality-assurance and quality-control data for groundwater sampling blanks, Toll Gate Creek, July-August 2007.-Continued

[Sample ID, synoptic-sample identification number; E, estimated value less than the reporting level and greater than the detection level; <, less than; mg/L, milligramsper liter; $\mu \mathrm{g} / \mathrm{L}$, micrograms per liter; ,-- no data

\begin{tabular}{|c|c|c|c|c|c|c|c|c|c|}
\hline Sample ID & Blank purpose & $\begin{array}{c}\text { Magnesium, } \\
\text { filtered } \\
\text { (mg/L) }\end{array}$ & $\begin{array}{c}\text { Manganese, } \\
\text { filtered } \\
(\mu \mathrm{g} / \mathrm{L})\end{array}$ & $\begin{array}{c}\text { Sodium, } \\
\text { filtered } \\
\text { (mg/L) }\end{array}$ & $\begin{array}{c}\text { Selenium } \\
\text { filtered } \\
(\mu \mathrm{g} / \mathrm{L})\end{array}$ & $\begin{array}{l}\text { Silica, } \\
\text { filtered } \\
\text { (mg/L) }\end{array}$ & $\begin{array}{l}\text { Sulfate, } \\
\text { filtered } \\
\text { (mg/L) }\end{array}$ & $\begin{array}{c}\text { Total } \\
\text { dissolved solids, } \\
\text { filtered (mg/L) }\end{array}$ & $\begin{array}{c}\text { Uranium, } \\
\text { filtered } \\
\text { ( } \mu \mathrm{g} / \mathrm{L})\end{array}$ \\
\hline URLUS-30 & Equipment blank & 0.029 & 0.4 & $0.1 \mathrm{E}$ & $<0.08$ & 0.05 & $0.18 \mathrm{E}$ & $<10$ & $<0.04$ \\
\hline URLUS-30 & Source solution blank & $<0.014$ & $<0.2$ & $<0.2$ & $<0.08$ & $<0.02$ & $<0.18$ & $<10$ & $<0.04$ \\
\hline URLUS-18 & Equipment blank & $<0.014$ & $<0.2$ & $<0.2$ & $<0.08$ & $<0.02$ & $<0.18$ & $<10$ & $<0.04$ \\
\hline SCTC-5 & Field blank & $<0.014$ & $<0.2$ & $<0.2$ & $<0.08$ & $0.01 \mathrm{E}$ & $<0.18$ & $<10$ & $<0.04$ \\
\hline WT-2 & Field blank & $<0.014$ & $<0.2$ & $<0.2$ & $<0.08$ & $<0.02$ & $<0.18$ & $<10$ & $<0.04$ \\
\hline WT-8 & Field blank & $0.009 \mathrm{E}$ & $0.2 \mathrm{E}$ & $<0.2$ & $<0.08$ & $0.01 \mathrm{E}$ & $<0.18$ & $<10$ & $<0.04$ \\
\hline \multicolumn{2}{|l|}{ Reporting level } & 0.014 & 0.2 & 0.2 & 0.08 & 0.018 & 0.18 & 10 & 0.04 \\
\hline \multicolumn{2}{|c|}{ Average blank concentration } & 0.016 & $<0.2$ & $<0.2$ & $<0.08$ & 0.02 & 0.2 & $<10$ & $<0.04$ \\
\hline \multicolumn{2}{|c|}{ Minimum blank concentration } & $<0.014$ & $<0.2$ & $<0.2$ & $<0.08$ & $<0.02$ & $<0.18$ & $<10$ & $<0.04$ \\
\hline \multicolumn{2}{|c|}{ Maximum blank concentration } & 0.029 & 0.4 & $0.1 \mathrm{E}$ & $<0.08$ & 0.05 & $0.18 \mathrm{E}$ & $<10$ & $<0.04$ \\
\hline \multicolumn{2}{|c|}{ Minimum environmental sample concentration } & 12.7 & 0.4 & 75.8 & 0.1 & 12.4 & 98 & 664 & 9.7 \\
\hline \multicolumn{2}{|c|}{ Maximum environmental sample concentration } & 96 & 1,960 & 665 & 264 & 31 & 2,370 & 4,400 & 100 \\
\hline
\end{tabular}

Table 2-2. Analytical quality-assurance and quality-control data for groundwater sampling blanks, Toll Gate Creek, July-August 2007.-Continued

[Sample ID, synoptic-sample identification number; E, estimated value less than the reporting level and greater than the detection level; <, less than; mg/L, milligramsper liter; $\mu \mathrm{g} / \mathrm{L}$, micrograms per liter; --, no data]

\begin{tabular}{|c|c|c|c|c|c|c|c|}
\hline Sample ID & Blank purpose & $\begin{array}{c}\text { Zinc, } \\
\text { filtered } \\
(\mu \mathrm{g} / \mathrm{L})\end{array}$ & $\begin{array}{c}\text { Ammonia } \\
\text { as nitrogen } \\
(\mathrm{mg} / \mathrm{L})\end{array}$ & $\begin{array}{c}\text { Nitrite } \\
\text { as nitrogen } \\
\text { (mg/L) }\end{array}$ & $\begin{array}{c}\text { Nitrite plus } \\
\text { nitrate as } \\
\text { nitrogen }(\mathrm{mg} / \mathrm{L})\end{array}$ & $\begin{array}{c}\text { Total } \\
\text { nitrogen } \\
\text { (mg/L) }\end{array}$ & $\begin{array}{c}\text { Ortho- } \\
\text { phosphate } \\
\text { (mg/L) }\end{array}$ \\
\hline URLUS-30 & Equipment blank & 3.8 & $<0.02$ & $<0.002$ & $<0.06$ & $<0.06$ & $0.003 \mathrm{E}$ \\
\hline URLUS-30 & Source solution blank & $<0.6$ & $<0.02$ & $<0.002$ & $<0.06$ & $<0.06$ & $<0.006$ \\
\hline URLUS-18 & Equipment blank & $<0.6$ & $0.014 \mathrm{E}$ & $<0.002$ & $<0.06$ & $<0.06$ & $<0.006$ \\
\hline SCTC-5 & Field blank & 4.9 & $<0.02$ & $0.001 \mathrm{E}$ & $<0.06$ & $<0.06$ & $<0.006$ \\
\hline WT-2 & Field blank & 1.2 & $<0.02$ & $<0.002$ & $<0.06$ & $0.04 \mathrm{E}$ & $<0.006$ \\
\hline WT-8 & Field blank & 1.5 & $<0.02$ & $<0.002$ & $<0.06$ & $<0.06$ & $<0.006$ \\
\hline \multicolumn{2}{|l|}{ Reporting level } & 0.6 & 0.02 & 0.002 & 0.06 & 0.06 & 0.006 \\
\hline \multicolumn{2}{|c|}{ Average blank concentration } & 2.1 & $<0.02$ & $<0.002$ & $<0.06$ & $<0.06$ & $<0.006$ \\
\hline \multicolumn{2}{|c|}{ Minimum blank concentration } & $<0.6$ & $<0.02$ & $<0.002$ & $<0.06$ & $<0.06$ & $<0.006$ \\
\hline \multicolumn{2}{|c|}{ Maximum blank concentration } & 4.9 & $0.014 \mathrm{E}$ & $0.001 \mathrm{E}$ & $<0.06$ & $0.04 \mathrm{E}$ & $0.003 \mathrm{E}$ \\
\hline \multicolumn{2}{|c|}{ Minimum environmental sample concentration } & 0.72 & $0.011 \mathrm{E}$ & $0.001 \mathrm{E}$ & $<0.06$ & 0.22 & 0.013 \\
\hline \multicolumn{2}{|c|}{ Maximum environmental sample concentration } & 7.3 & 0.056 & 0.009 & 18.6 & 20.3 & 0.094 \\
\hline
\end{tabular}




\section{Precision and Bias of Laboratory Results}

Precision is a measure of the reproducibility of an analytical data set and can be evaluated by calculating the relative percent difference (RPD) between multiple replicates (U.S. Environmental Protection Agency, 1987). The RPD is calculated using the formula (U.S. Environmental Protection Agency, 1987):

$$
R P D=\left(\frac{|x 1-x 2|}{\left.\frac{(x 1+x 2)}{2}\right)} * 100\right.
$$

where

$\mathrm{x}_{1} \quad$ is the measured value of the first replicate and $\mathrm{x}_{2}$ is the measured value of the second replicate

(U.S. Environmental Protection Agency, 1987).

For the Toll Gate Creek study, precision was evaluated by collecting sequential-replicate samples for surfacewater and groundwater. Sequential-replicate samples were collected twice during each day of surface-water synoptic sampling except on August 1, 2007, when only one replicate sample was collected (table 2-3). Three sequential-replicate samples were collected during groundwater sampling (table 2-4). The RPDs were calculated for replicates, and the average, minimum, and maximum values were determined for surface water and groundwater (tables 2-3 and 2-4, respectively). An RPD of 10 percent was chosen as an upper limit for acceptable replication of analyses. The overall average precision is the average of the RPDs for all constituents and all replicate samples. The overall average precision was \pm 6.23 percent for surface-water samples and \pm 7.30 percent for groundwater samples, which indicates good overall precision of analytical results.

There were four constituents for surface-water samples for which the average RPD was greater than 10 percent: aluminum (filtered and unfiltered), iron (filtered and unfiltered), zinc (filtered and unfiltered), and orthophosphate (table 2-3). The average precision for filtered selenium in surfacewater samples was \pm 7.7 percent with a minimum value of \pm 2.4 percent and a maximum value of \pm 21.6 percent for one replicate pair, indicating acceptable precision for filtered (dissolved) selenium concentrations in surface water. Precision results for groundwater replicates (table 2-4) indicate results similar to those for surface water with average RPD values exceeding 10 percent for filtered aluminum, iron, and zinc. The average precision for filtered selenium groundwater samples was \pm 2.0 percent with a minimum value of \pm 1.5 percent and a maximum value of \pm 3.0 percent for one replicate pair, indicating acceptable precision for filtered (dissolved) selenium concentrations in groundwater.

The lack of precision for aluminum, iron, and zinc results indicates variability in the laboratory analysis of these constituents, and may also explain the variability in aluminum and zinc concentrations observed for the blank samples. Because these constituents were detected at low concentrations in environmental samples and interpretation of these data are not the primary emphasis of this study, the imprecise concentrations reported for aluminum, iron, and zinc do not affect interpretations presented herein.

Bias (accuracy) in a sample measurement represents systematic error in an analytical method (U.S. Environmental Protection Agency, 1987). The bias of an analytical method is computed from analysis of known laboratory standards from the formula:

$$
\operatorname{Bias}=((\mathrm{R}-\mathrm{S}) / \mathrm{S}) * 100
$$

where

$\mathrm{R}$ is the constituent concentration reported by the laboratory and

$\mathrm{S} \quad$ is the constituent concentration in the standard (U.S. Environmental Protection Agency, 1987)

To evaluate bias for the Toll Gate Creek study, USGS standard reference water, T-147 (Farrar, 1997), was submitted to the laboratory (National Water Quality Laboratory, NWQL) along with bromide and sulfate spike solutions to determine whether the bromide tracer and elevated stream-sulfate concentrations would interfere with analyses provided by the NWQL (table 2-5). Three samples each of $1 \mathrm{mg} / \mathrm{L}, 3 \mathrm{mg} / \mathrm{L}$, and $5 \mathrm{mg} / \mathrm{L}$ bromide spikes without sulfate, three samples of $1 \mathrm{mg} / \mathrm{L}$ bromide combined with $1,000 \mathrm{mg} / \mathrm{L}$ sulfate, and one sample with no spike solution were submitted to NWQL for analysis (table 2-5). The NWQL results were compared to the acceptable range of T-147 values. The acceptable range was defined as the most probable value (median value of analysis of T-147 during the proving period) plus or minus the F-pseudosigma (the nonparametric statistic for deviation; Farrar, 1997).

Iron, sodium, selenium, and uranium were consistently within the acceptable range (fig. 2-1). Three elevated concentrations of sodium (table 2-5) were from the sodium sulfate spikes and are not plotted on figure $2-1$. Silica and zinc plotted below the true value but within the acceptable range for all but three samples, which were below the acceptable range (fig. 2-1). The three samples were spikes containing $1 \mathrm{mg} / \mathrm{L}$ bromide and $1,000 \mathrm{mg} / \mathrm{L}$ sulfate, and the results indicate some interference because of the presence of elevated sulfate concentrations. Concentrations of sulfate in the environmental samples ranged up to 2,370 $\mathrm{mg} / \mathrm{L}$ (table 2-2). Therefore, environmental samples having sulfate concentrations greater than $1,000 \mathrm{mg} / \mathrm{L}$ may have a low bias in zinc and silica concentrations. As zinc and silica are not critical to the interpretations presented herein, the results of this report are not affected by the sulfate interference, but the results are described for those who might use the data for other purposes. Aluminum was consistently at or above the true value with only two samples greater than the acceptable range. The two samples having the most elevated aluminum values were two of the three having spikes of $1 \mathrm{mg} / \mathrm{L}$ bromide. The failure of 2 of the 10 samples is likely not from the bromide spike concentration but from unidentified problems with blank and replicate samples that were described previously in this section and in the "Effects of Sample Processing on Environmental Sample Results" section of this report. Calcium, magnesium, and manganese were consistently 
Table 2-3. Analytical quality-assurance and quality-control data for surface-water replicates, Toll Gate Creek, July-August 2007.

[Sample ID, synoptic-sample identification number; (A) or (B) Suffix on sample indicates samples that are part of a field replicate; E, estimated value less than the laboratory reporting level; <, less than; $\mathrm{mg} / \mathrm{L}$, milligrams per liter; $\mu \mathrm{g} / \mathrm{L}$, micrograms per liter; Relative $\%$ Difference, the absolute value of difference between replicate analyses divided by the average of the analyses and expressed as percent;

--, no data; Overall avg. precision, the average of Relative \% Difference for all analytes and replicate samples]

\begin{tabular}{|c|c|c|c|c|c|c|c|c|c|}
\hline Sample ID, Sample date & pH, lab & $\begin{array}{c}\text { Specific } \\
\text { conductance, lab } \\
(\mu \mathrm{s} / \mathrm{cm})\end{array}$ & $\begin{array}{c}\text { Specific } \\
\text { conductance, field } \\
(\mu \mathrm{s} / \mathrm{cm})\end{array}$ & Hardness & $\begin{array}{c}\text { Alkalinity, } \\
\text { (mg/L CaCO })\end{array}$ & $\begin{array}{l}\text { Aluminum, } \\
\text { filtered } \\
(\mu \mathrm{g} / \mathrm{L})\end{array}$ & $\begin{array}{c}\text { Aluminum, } \\
\text { unfiltered } \\
(\mu \mathrm{g} / \mathrm{L})\end{array}$ & $\begin{array}{l}\text { Bromide, } \\
\text { filtered } \\
(\mathrm{mg} / \mathrm{L})\end{array}$ & $\begin{array}{l}\text { Calcium, } \\
\text { filtered } \\
\text { (mg/L) }\end{array}$ \\
\hline TG-11473A, 7/26/07 & 7.8 & 2,130 & 2,260 & 650 & 193 & 26.1 & 86.0 & 1.62 & 202 \\
\hline TG-11473B, 7/26/07 & 7.8 & 2,130 & 2,280 & 650 & 195 & 66.3 & 74.0 & 1.68 & 201 \\
\hline Relative \%Difference & 0.0 & 0.0 & 0.9 & 0.0 & 1.0 & 87.0 & 15.0 & 3.6 & 0.5 \\
\hline TG-9408A, 7/26/07 & 7.9 & 2,240 & 2,360 & 670 & 165 & 18.6 & 216 & 2.33 & 203 \\
\hline TG-9408B, 7/26/07 & 8.0 & 2,200 & 2,340 & 670 & 169 & 17.9 & 141 & 2.34 & 206 \\
\hline Relative \%Difference & 1.3 & 1.8 & 0.9 & 0.0 & 2.4 & 3.8 & 42.0 & 0.4 & 1.5 \\
\hline TG-7818A, 7/29/07 & 8.1 & 1,440 & 1,440 & 440 & 163 & 20.2 & 195 & 1.00 & 136 \\
\hline TG-7818B, 7/29/07 & 8.1 & 1,450 & 1,440 & 440 & 166 & 14.6 & 178 & 0.99 & 136 \\
\hline Relative \%Difference & 0.0 & 0.7 & 0.0 & 0.0 & 1.8 & 32.2 & 9.1 & 1.0 & 0.0 \\
\hline TG-4695A, 7/29/07 & 7.8 & 1,640 & 1,620 & 520 & 180 & 10.9 & 238 & 1.38 & 158 \\
\hline TG-4695B, 7/29/07 & 7.8 & 1,640 & 1,620 & 510 & 181 & 15.5 & 245 & 1.39 & 155 \\
\hline Relative \%Difference & 0.0 & 0.0 & 0.0 & 1.9 & 0.6 & 34.8 & 2.9 & 0.7 & 1.9 \\
\hline TG-1536A, 8/1/07 & 7.8 & 2,000 & 2,020 & 620 & 194 & $26.6 \mathrm{E}$ & 302 & 0.82 & 184 \\
\hline TG-1536B, 8/1/07 & 7.8 & 2,000 & 2,030 & 640 & 196 & 24.1 & 292 & 0.85 & 190 \\
\hline Relative \%Difference & 0.0 & 0.0 & 0.5 & 3.2 & 1.0 & 9.7 & 3.4 & 3.6 & 3.2 \\
\hline TG-4216A, 8/2/07 & 7.8 & 2,070 & 2,020 & 610 & 191 & 15.8 & 492 & 2.40 & 182 \\
\hline TG-4216B, 8/2/07 & 7.8 & 2,080 & 1,990 & 620 & 192 & 1.60 & 463 & 2.40 & 185 \\
\hline Relative \%Difference & 0.0 & 0.5 & 1.5 & 1.6 & 0.5 & 163.2 & 6.1 & 0.0 & 1.6 \\
\hline TG-2148A, 8/2/07 & 8.2 & 2,140 & 2,060 & 670 & 181 & $1.50 \mathrm{E}$ & 148 & 3.05 & 197 \\
\hline TG-2148B, 8/2/07 & 8.2 & 2,130 & 2,100 & 630 & 181 & $0.90 \mathrm{E}$ & 116 & 3.03 & 186 \\
\hline Relative \%Difference & 0.0 & 0.5 & 1.9 & 6.2 & 0.0 & 50.0 & 24.2 & 0.7 & 5.7 \\
\hline Average difference & 0.2 & 0.5 & 0.8 & 1.8 & 1.1 & 54.4 & 14.7 & 1.4 & 2.1 \\
\hline Minimum & 0.0 & 0.0 & 0.0 & 0.0 & 0.0 & 3.8 & 2.9 & 0.0 & 0.0 \\
\hline Maximum & 1.3 & 1.8 & 1.9 & 6.2 & 2.4 & 163.2 & 42.0 & 3.6 & 5.7 \\
\hline Overall avg. precision & 6.23 & & & & & & & & \\
\hline
\end{tabular}


Table 2-3. Analytical quality-assurance and quality-control data for surface-water replicates, Toll Gate Creek, July-August 2007.—Continued

[Sample ID, synoptic-sample identification number; (A) or (B) Suffix on sample indicates samples that are part of a field replicate; E, estimated value less than the laboratory reporting level; <, less than; $\mathrm{mg} / \mathrm{L}$, milligrams per liter; $\mu \mathrm{g} / \mathrm{L}$, micrograms per liter; Relative $\%$ Difference, the absolute value of difference between replicate analyses divided by the average of the analyses and expressed as percent; ,-- no data; Overall avg. precision, the average of Relative \% Difference for all analytes and replicate samples]

\begin{tabular}{|c|c|c|c|c|c|c|c|c|}
\hline Sample ID, Sample date & $\begin{array}{c}\text { Calcium, } \\
\text { unfiltered } \\
\text { (mg/L) }\end{array}$ & $\begin{array}{c}\text { Chloride, } \\
\text { filtered } \\
\text { (mg/L) }\end{array}$ & $\begin{array}{c}\text { Iron, } \\
\text { filtered } \\
\text { ( } \mathrm{gg} / \mathrm{L} \text { ) }\end{array}$ & $\begin{array}{c}\text { Iron, } \\
\text { unfiltered } \\
(\mu \mathrm{g} / \mathrm{L})\end{array}$ & $\begin{array}{c}\text { Fluoride, } \\
\text { filtered } \\
\text { (mg/L) }\end{array}$ & $\begin{array}{c}\text { Manganese, } \\
\text { filtered } \\
(\mu \mathrm{g} / \mathrm{L})\end{array}$ & $\begin{array}{c}\text { Manganese, } \\
\text { unfiltered } \\
(\mu \mathrm{g} / \mathrm{L})\end{array}$ & $\begin{array}{c}\text { Magnesium, } \\
\text { filtered } \\
\text { (mg/L) }\end{array}$ \\
\hline TG-11473A, 7/26/07 & 205 & 147 & $17.0 \mathrm{E}$ & 134 & 0.67 & 298 & 335 & 35.9 \\
\hline TG-11473B, 7/26/07 & 205 & 149 & 22.0 & 111 & 0.67 & 270 & 320 & 35.4 \\
\hline Relative \%Difference & 0.0 & 1.4 & 25.6 & 18.8 & 0.0 & 9.9 & 4.6 & 1.4 \\
\hline TG-9408A, 7/26/07 & 219 & 151 & $12.0 \mathrm{E}$ & 258 & 0.62 & 132 & 171 & 38.6 \\
\hline TG-9408B, 7/26/07 & 219 & 150 & $11.0 \mathrm{E}$ & 186 & 0.64 & 120 & 157 & 38.2 \\
\hline Relative \%Difference & 0.0 & 0.7 & 8.7 & 32.4 & 3.2 & 9.5 & 8.5 & 1.0 \\
\hline TG-7818A, 7/29/07 & 134 & 94.8 & 13.0 & 248 & 0.54 & 118 & 161 & 24.5 \\
\hline TG-7818B, 7/29/07 & 136 & 95.7 & 16.0 & 244 & 0.55 & 119 & 159 & 24.7 \\
\hline Relative \%Difference & 1.5 & 0.9 & 20.7 & 1.6 & 1.8 & 0.8 & 1.3 & 0.8 \\
\hline TG-4695A, 7/29/07 & 155 & 94.4 & 13.0 & 303 & 0.60 & 209 & 256 & 30.0 \\
\hline TG-4695B, 7/29/07 & 151 & 94.9 & 12.0 & 317 & 0.61 & 208 & 257 & 29.4 \\
\hline Relative \%Difference & 2.6 & 0.5 & 8.0 & 4.5 & 1.7 & 0.5 & 0.4 & 2.0 \\
\hline TG-1536A, 8/1/07 & 198 & 132 & 28.0 & 441 & 0.61 & 366 & 426 & 39.6 \\
\hline TG-1536B, 8/1/07 & 190 & 133 & 32.0 & 416 & 0.61 & 370 & 418 & 39.5 \\
\hline Relative \%Difference & 4.1 & 0.8 & 13.3 & 5.8 & 0.0 & 1.1 & 1.9 & 0.3 \\
\hline TG-4216A, 8/2/07 & 192 & 133 & 22.0 & 725 & 0.63 & 482 & 553 & 36.9 \\
\hline TG-4216B, 8/2/07 & 187 & 133 & 19.0 & 714 & 0.57 & 464 & 546 & 37.2 \\
\hline Relative \%Difference & 2.6 & 0.0 & 14.6 & 1.5 & 10.0 & 3.8 & 1.3 & 0.8 \\
\hline TG-2148A, 8/2/07 & 195 & 157 & 26.0 & 259 & 0.62 & 274 & 274 & 43.1 \\
\hline TG-2148B, 8/2/07 & 188 & 157 & 20.0 & 196 & 0.59 & 256 & 268 & 41.2 \\
\hline Relative \%Difference & 3.7 & 0.0 & 26.1 & 27.7 & 5.0 & 6.8 & 2.2 & 4.5 \\
\hline Average difference & 2.1 & 0.6 & 16.7 & 13.2 & 3.1 & 4.6 & 2.9 & 1.5 \\
\hline Minimum & 0.0 & 0.0 & 8.0 & 1.5 & 0.0 & 0.5 & 0.4 & 0.3 \\
\hline Maximum & 4.1 & 1.4 & 26.1 & 32.4 & 10.0 & 9.9 & 8.5 & 4.5 \\
\hline Overall avg. precision & & & & & & & & \\
\hline
\end{tabular}


[Sample ID, synoptic-sample identification number; (A) or (B) Suffix on sample indicates samples that are part of a field replicate; E, estimated value less than the laboratory reporting level; <, less than; $\mathrm{mg} / \mathrm{L}$, milligrams per liter; $\mu \mathrm{g} / \mathrm{L}$, micrograms per liter; Relative \% Difference, the absolute value of difference between replicate analyses divided by the average of the analyses and expressed as percent;

--, no data; Overall avg. precision, the average of Relative \% Difference for all analytes and replicate samples]

\begin{tabular}{|c|c|c|c|c|c|c|c|c|c|}
\hline Sample ID, Sample date & $\begin{array}{l}\text { Magnesium, } \\
\text { unfiltered } \\
\text { (mg/L) }\end{array}$ & $\begin{array}{l}\text { Sodium, } \\
\text { filtered } \\
\text { (mg/L) }\end{array}$ & $\begin{array}{c}\text { Sodium, } \\
\text { unfiltered } \\
\text { (mg/L) }\end{array}$ & $\begin{array}{l}\text { Sodium } \\
\text { adsorption } \\
\text { ratio }\end{array}$ & $\begin{array}{l}\text { Selenium, } \\
\text { filtered } \\
\text { ( } \mu \mathrm{g} / \mathrm{L})\end{array}$ & $\begin{array}{c}\text { Selenium, } \\
\text { unfiltered } \\
(\mu \mathrm{g} / \mathrm{L})\end{array}$ & $\begin{array}{c}\text { Silica, } \\
\text { filtered } \\
\text { (mg/L) }\end{array}$ & $\begin{array}{c}\text { Sulfate, } \\
\text { filtered } \\
\text { (mg/L) }\end{array}$ & $\begin{array}{c}\text { Total } \\
\text { dissolved solids, } \\
\text { filtered } \\
\text { (mg/L) }\end{array}$ \\
\hline TG-11473A, 7/26/07 & 36.4 & 242 & 223 & 4.1 & 13.7 & 12.02 & 11.9 & 709 & 1580 \\
\hline TG-11473B, 7/26/07 & 36.9 & 243 & 222 & 4.2 & 15.2 & 12.18 & 11.4 & 720 & 1580 \\
\hline Relative \%Difference & 1.4 & 0.4 & 0.4 & 2.4 & 10.4 & 1.3 & 4.3 & 1.5 & 0.0 \\
\hline TG-9408A, 7/26/07 & 42.7 & 241 & 231 & 4.1 & 15.1 & 12.25 & 11.0 & 784 & 1620 \\
\hline TG-9408B, 7/26/07 & 40.7 & 245 & 234 & 4.1 & 15.8 & 12.67 & 10.6 & 782 & 1610 \\
\hline Relative \%Difference & 4.8 & 1.6 & 1.3 & 0.0 & 4.5 & 3.4 & 3.7 & 0.3 & 0.6 \\
\hline TG-7818A, 7/29/07 & 25.6 & 143 & 130 & 3.0 & 7.7 & 6.65 & 10.8 & 442 & 972 \\
\hline TG-7818B, 7/29/07 & 25.9 & 142 & 130 & 2.9 & 7.9 & 6.62 & 10.9 & 445 & 1010 \\
\hline Relative \%Difference & 1.2 & 0.7 & 0.0 & 3.4 & 2.6 & 0.5 & 0.9 & 0.7 & 3.8 \\
\hline TG-4695A, 7/29/07 & 30.2 & 154 & 149 & 2.9 & 8.4 & 7.25 & 11.5 & 526 & 1200 \\
\hline TG-4695B, 7/29/07 & 30.3 & 153 & 145 & 3.0 & 8.7 & 7.17 & 11.6 & 529 & 1210 \\
\hline Relative \%Difference & 0.3 & 0.7 & 2.7 & 3.4 & 3.5 & 1.1 & 0.9 & 0.6 & 0.8 \\
\hline TG-1536A, 8/1/07 & 39.0 & 198 & 191 & 3.5 & $<11.6$ & 9.43 & 12.5 & 684 & 1500 \\
\hline TG-1536B, 8/1/07 & 40.4 & 203 & 188 & 3.5 & 12.7 & 9.32 & 12.6 & 685 & 1480 \\
\hline Relative \%Difference & 3.5 & 2.5 & 1.6 & 0.0 & 9.0 & 1.2 & 0.8 & 0.1 & 1.3 \\
\hline TG-4216A, 8/2/07 & 41.0 & 216 & 207 & 3.8 & 12.4 & 11.29 & 11.8 & 707 & 1560 \\
\hline TG-4216B, 8/2/07 & 39.0 & 218 & 205 & 3.8 & 15.4 & 10.61 & 11.6 & 717 & 1540 \\
\hline Relative \%Difference & 5.0 & 0.9 & 1.0 & 0.0 & 21.6 & 6.2 & 1.7 & 1.4 & 1.3 \\
\hline TG-2148A, 8/2/07 & 43.1 & 240 & 220 & 4.0 & 12.6 & 11.05 & 14.5 & 711 & 1600 \\
\hline TG-2148B, 8/2/07 & 40.3 & 225 & 207 & 3.9 & 12.3 & 11.08 & 13.6 & 722 & 1590 \\
\hline Relative \%Difference & 6.7 & 6.5 & 6.1 & 2.5 & 2.4 & 0.3 & 6.4 & 1.5 & 0.6 \\
\hline Average difference & 3.3 & 1.9 & 1.9 & 1.7 & 7.7 & 2.0 & 2.7 & 0.9 & 1.2 \\
\hline Minimum & 0.3 & 0.4 & 0.0 & 0.0 & 2.4 & 0.3 & 0.8 & 0.1 & 0.0 \\
\hline Maximum & 6.7 & 6.5 & 6.1 & 3.4 & 21.6 & 6.2 & 6.4 & 1.5 & 3.8 \\
\hline
\end{tabular}


Table 2-3. Analytical quality-assurance and quality-control data for surface-water replicates, Toll Gate Creek, July-August 2007.—Continued

[Sample ID, synoptic-sample identification number; (A) or (B) Suffix on sample indicates samples that are part of a field replicate; E, estimated value less than the laboratory reporting level; <, less than; $\mathrm{mg} / \mathrm{L}$, milligrams per liter; $\mu \mathrm{g} / \mathrm{L}$, micrograms per liter; Relative \% Difference, the absolute value of difference between replicate analyses divided by the average of the analyses and expressed as percent; ,-- no data; Overall avg. precision, the average of Relative \% Difference for all analytes and replicate samples]

\begin{tabular}{|c|c|c|c|c|c|c|c|c|c|c|}
\hline Sample ID, Sample date & $\begin{array}{c}\text { Uranium, } \\
\text { filtered } \\
\text { ( } \mu \mathrm{g} / \mathrm{L})\end{array}$ & $\begin{array}{c}\text { Uranium, } \\
\text { unfiltered } \\
(\mu \mathrm{g} / \mathrm{L})\end{array}$ & $\begin{array}{c}\text { Zinc, } \\
\text { filtered } \\
\text { ( } \mu \mathrm{g} / \mathrm{L})\end{array}$ & $\begin{array}{c}\text { Zinc, } \\
\text { unfiltered } \\
(\mu \mathrm{g} / \mathrm{L})\end{array}$ & $\begin{array}{c}\text { Ammonia } \\
\text { as nitrogen } \\
(\mathrm{mg} / \mathrm{L})\end{array}$ & $\begin{array}{c}\text { Nitrite } \\
\text { as nitrogen } \\
(\mathrm{mg} / \mathrm{L})\end{array}$ & $\begin{array}{l}\text { Nitrite plus } \\
\text { nitrate } \\
\text { as nitrogen } \\
\text { (mg/L) }\end{array}$ & $\begin{array}{c}\text { Total } \\
\text { nitrogen } \\
\text { (mg/L) }\end{array}$ & $\begin{array}{c}\text { Ortho- } \\
\text { phosphate } \\
\text { (mg/L) }\end{array}$ & $\begin{array}{c}\text { Phosphorous } \\
\text { (mg/L) }\end{array}$ \\
\hline TG-11473A, 7/26/07 & 20.0 & 20.9 & 4.80 & 4.85 & -- & -- & -- & -- & -- & -- \\
\hline TG-11473B, 7/26/07 & 20.4 & 21.1 & 2.70 & 4.51 & -- & -- & -- & -- & -- & -- \\
\hline Relative \%Difference & 2.0 & 1.0 & 56.0 & 7.3 & -- & -- & - & - & - & -- \\
\hline TG-9408A, 7/26/07 & 21.6 & 22.9 & 0.92 & 2.97 & -- & -- & -- & -- & -- & -- \\
\hline TG-9408B, 7/26/07 & 21.3 & 22.1 & 0.63 & 2.43 & -- & -- & -- & -- & -- & -- \\
\hline Relative \%Difference & 1.4 & 3.6 & 37.4 & 20.0 & -- & -- & -- & -- & -- & -- \\
\hline TG-7818A, 7/29/07 & 11.6 & 12.9 & 5.10 & 5.25 & 0.03 & 0.02 & 0.47 & 1.33 & 0.02 & 0.10 \\
\hline TG-7818B, 7/29/07 & 12.0 & 13.1 & 2.80 & 4.64 & 0.03 & 0.02 & 0.46 & 1.33 & 0.03 & 0.10 \\
\hline Relative \%Difference & 3.4 & 1.5 & 58.2 & 12.3 & 0.0 & 0.0 & 2.2 & 0.0 & 20.4 & 3.9 \\
\hline TG-4695A, 7/29/07 & 15.9 & 16.4 & 6.60 & 2.70 & -- & -- & -- & -- & -- & -- \\
\hline TG-4695B, 7/29/07 & 16.1 & 16.3 & 5.70 & 2.76 & -- & -- & -- & -- & -- & -- \\
\hline Relative \%Difference & 1.3 & 0.6 & 14.6 & 2.1 & -- & -- & -- & -- & -- & -- \\
\hline TG-1536A, 8/1/07 & $<20.0$ & 19.8 & $<3.7$ & 3.88 & 0.19 & 0.02 & 0.57 & 1.49 & 0.04 & 0.10 \\
\hline TG-1536B, 8/1/07 & 21.9 & 19.6 & 1.80 & 3.19 & 0.19 & 0.02 & 0.58 & 1.48 & 0.05 & 0.10 \\
\hline Relative \%Difference & 9.1 & 1.0 & 68.1 & 19.5 & 0.5 & 0.0 & 1.7 & 0.7 & 14.0 & 1.0 \\
\hline TG-4216A, 8/2/07 & 17.9 & 19.8 & 3.20 & 7.41 & 0.14 & 0.03 & 0.55 & 1.66 & 0.02 & 0.12 \\
\hline TG-4216B, 8/2/07 & 20.9 & 19.5 & 3.30 & 6.78 & 0.14 & 0.03 & 0.55 & 1.56 & 0.02 & 0.13 \\
\hline Relative \%Difference & $\mathbf{1 5 . 5}$ & 1.5 & 3.1 & 8.9 & 2.8 & 0.0 & 0.0 & 6.2 & 5.1 & 11.9 \\
\hline TG-2148A, 8/2/07 & 17.9 & 19.5 & 1.10 & 2.16 & 0.09 & 0.03 & 0.53 & 1.32 & 0.03 & 0.08 \\
\hline TG-2148B, 8/2/07 & 17.6 & 19.4 & 1.10 & 1.84 & 0.10 & 0.03 & 0.54 & 1.35 & 0.03 & 0.08 \\
\hline Relative \%Difference & 1.7 & 0.5 & 0.0 & 16.0 & 5.3 & 0.0 & 1.9 & 2.2 & 3.9 & 6.1 \\
\hline Average difference & 4.9 & 1.4 & 33.9 & 12.3 & 2.2 & 0.0 & 1.4 & 2.3 & 10.9 & 5.7 \\
\hline Minimum & 1.3 & 0.5 & 0.0 & 2.1 & 0.0 & 0.0 & 0.0 & 0.0 & 3.9 & 1.0 \\
\hline Maximum & 15.5 & 3.6 & 68.1 & 20.0 & 5.3 & 0.0 & 2.2 & 6.2 & 20.4 & 11.9 \\
\hline
\end{tabular}


[Sample ID, synoptic-sample identification number; (A) or (B) Suffix on sample indicates samples that are part of a field replicate; E, estimated value less than the laboratory reporting level; <, less than; $\mathrm{mg} / \mathrm{L}$, milligrams per liter; $\mu \mathrm{g} / \mathrm{L}$, micrograms per liter; Relative $\%$ Difference, the absolute value of difference between replicate analyses divided by the average of the analyses and expressed as percent; Overall Avg. Precision, the average of Relative \% Difference for all analytes and replicate samples]

\begin{tabular}{|c|c|c|c|c|c|c|c|c|c|c|}
\hline Sample ID, Sample date & pH, lab & $\begin{array}{c}\text { Specific } \\
\text { conductance, } \\
\text { lab } \\
(\mu \mathrm{s} / \mathrm{cm})\end{array}$ & $\begin{array}{c}\text { Alkalinity, } \\
\text { (mg/L CaCO })\end{array}$ & $\begin{array}{c}\text { Bicarb- } \\
\text { onate } \\
\text { (mg/L) }\end{array}$ & $\begin{array}{l}\text { Aluminum, } \\
\text { filtered } \\
(\mu \mathrm{g} / \mathrm{L})\end{array}$ & $\begin{array}{c}\text { Bromide, } \\
\text { filtered } \\
\text { (mg/L) }\end{array}$ & $\begin{array}{c}\text { Calcium, } \\
\text { filtered } \\
\text { (mg/L) }\end{array}$ & $\begin{array}{c}\text { Chloride, } \\
\text { filtered } \\
\text { (mg/L) }\end{array}$ & $\begin{array}{c}\text { Iron, } \\
\text { filtered } \\
\text { ( } \mu \mathrm{g} / \mathrm{L} \text { ) }\end{array}$ & $\begin{array}{c}\text { Fluoride, } \\
\text { filtered } \\
\text { (mg/L) }\end{array}$ \\
\hline ET-2A, 7/16/07 & 7.3 & 1,540 & 212 & 258 & $1.3 \mathrm{E}$ & 0.55 & 208 & 73.3 & 6 & 0.73 \\
\hline ET-2B, 7/16/07 & 7.3 & 1,540 & 211 & 257 & $0.9 \mathrm{E}$ & 0.56 & 210 & 72.9 & 6 & 0.76 \\
\hline Relative \% Difference & 0.0 & 0.0 & 0.5 & 0.4 & 36.4 & 1.8 & 1.0 & 0.5 & 0.0 & 4.0 \\
\hline WT-12A, 7/19/07 & 7.5 & 1,040 & 272 & 332 & $<1.6$ & 0.34 & 111 & 76.8 & 6 & 0.66 \\
\hline WT-12B, 7/19/07 & 7.4 & 1,040 & 292 & 356 & $<1.6$ & 0.37 & 112 & 77.3 & 6 & 0.6 \\
\hline Relative \% Difference & 1.3 & 0.0 & 7.1 & 7.0 & 0.0 & 8.5 & 0.9 & 0.6 & 0.0 & 9.5 \\
\hline WT-4A, 7/24/07 & 7.1 & 3,740 & 372 & 452 & $<16.0$ & 1.55 & 530 & 149 & $9 \mathrm{E}$ & 0.56 \\
\hline WT-4B, 7/24/07 & 7.2 & 3,730 & 372 & 454 & 150.0 & 1.58 & 536 & 149 & 18 & 0.51 \\
\hline Relative \% Difference & 1.4 & 0.3 & 0.0 & 0.4 & 161.4 & 1.9 & 1.1 & 0.0 & 66.7 & 9.3 \\
\hline Average & 0.9 & 0.1 & 2.5 & 2.6 & 65.9 & 4.1 & 1.0 & 0.4 & 22.2 & 7.6 \\
\hline Minimum & 0.0 & 0.0 & 0.0 & 0.4 & 0.0 & 1.8 & 0.9 & 0.0 & 0.0 & 4.0 \\
\hline Maximum & 1.4 & 0.3 & 7.1 & 7.0 & 161.4 & 8.5 & 1.1 & 0.6 & 66.7 & 9.5 \\
\hline Overall avg. precision & 7.30 & & & & & & & & & \\
\hline
\end{tabular}


Table 2-4. Analytical quality-assurance and quality-control data for groundwater replicates, Toll Gate Creek, July-August 2007.—Continued

[Sample ID, synoptic-sample identification number; (A) or (B) Suffix on sample indicates samples that are part of a field replicate; E, estimated value less than the laboratory reporting level; <, less than; $\mathrm{mg} / \mathrm{L}$, milligrams per liter; $\mu \mathrm{g} / \mathrm{L}$, micrograms per liter; Relative \% Difference, the absolute value of difference between replicate analyses divided by the average of the analyses and expressed as percent; Overall Avg. Precision, the average of Relative \% Difference for all analytes and replicate samples]

\begin{tabular}{|c|c|c|c|c|c|c|c|c|c|}
\hline Sample ID, Sample date & $\begin{array}{c}\text { Potassium, } \\
\text { filtered } \\
\text { (mg/L) }\end{array}$ & $\begin{array}{l}\text { Magnesium, } \\
\text { filtered } \\
\text { (mg/L) }\end{array}$ & $\begin{array}{c}\text { Manganese, } \\
\text { filtered } \\
(\mu \mathrm{g} / \mathrm{L})\end{array}$ & $\begin{array}{l}\text { Sodium, } \\
\text { filtered } \\
\text { (mg/L) }\end{array}$ & $\begin{array}{c}\text { Selenium, } \\
\text { filtered } \\
(\mu \mathrm{g} / \mathrm{L})\end{array}$ & $\begin{array}{l}\text { Silica, } \\
\text { filtered } \\
\text { (mg/L) }\end{array}$ & $\begin{array}{c}\text { Sulfate, } \\
\text { filtered } \\
\text { (mg/L) }\end{array}$ & $\begin{array}{c}\text { Total } \\
\text { dissolved } \\
\text { solids, filtered } \\
\text { (mg/L) }\end{array}$ & $\begin{array}{c}\text { Uranium, } \\
\text { filtered } \\
\text { ( } \mu \mathrm{g} / \mathrm{L})\end{array}$ \\
\hline ET-2A, 7/16/07 & 0.79 & 28.1 & 0.4 & 96.6 & 62.5 & 19.7 & 513 & 1,190 & 17.3 \\
\hline ET-2B, 7/16/07 & 0.85 & 28.2 & 0.4 & 97.7 & 61.5 & 19.8 & 512 & 1,190 & 17.0 \\
\hline Relative \% Difference & 7.3 & 0.4 & 0.0 & 1.1 & 1.6 & 0.5 & 0.2 & 0.0 & 1.7 \\
\hline WT-12A, 7/19/07 & 1.93 & 22.1 & 1.5 & 75.8 & 6.6 & 22.1 & 98.1 & 679 & 15.0 \\
\hline WT-12B, 7/19/07 & 1.94 & 22 & 1.5 & 77 & 6.5 & 22.2 & 98.6 & 664 & 15.8 \\
\hline Relative \% Difference & 0.5 & 0.5 & 0.0 & 1.6 & 1.5 & 0.5 & 0.5 & 2.2 & 5.2 \\
\hline WT-4A, 7/24/07 & 2.24 & 84.5 & 13.1 & 316 & 37.2 & 20.9 & 1,730 & 3,310 & 83.3 \\
\hline WT-4B, 7/24/07 & 2.17 & 84.9 & 13.8 & 318 & 36.1 & 21.5 & 1,730 & 3,310 & 83.0 \\
\hline Relative \% Difference & 3.2 & 0.5 & 5.2 & 0.6 & 3.0 & 2.8 & 0.0 & 0.0 & 0.4 \\
\hline Average & 3.7 & 0.4 & 1.7 & 1.1 & 2.0 & 1.3 & 0.2 & 0.7 & 2.4 \\
\hline Minimum & 0.5 & 0.4 & 0.0 & 0.6 & 1.5 & 0.5 & 0.0 & 0.0 & 0.4 \\
\hline Maximum & 7.3 & 0.5 & 5.2 & 1.6 & 3.0 & 2.8 & 0.5 & 2.2 & 5.2 \\
\hline Overall avg. precision & & & & & & & & & \\
\hline
\end{tabular}


[Sample ID, synoptic-sample identification number; (A) or (B) Suffix on sample indicates samples that are part of a field replicate; E, estimated value less than the laboratory reporting level; <, less than; $\mathrm{mg} / \mathrm{L}$, milligrams per liter; $\mu \mathrm{g} / \mathrm{L}$, micrograms per liter; Relative $\%$ Difference, the absolute value of difference between replicate analyses divided by the average of the analyses and expressed as percent; Overall Avg. Precision, the average of Relative \% Difference for all analytes and replicate samples]

\begin{tabular}{|c|c|c|c|c|c|c|c|c|}
\hline Sample ID, Sample date & $\begin{array}{c}\text { Zinc, filtered } \\
(\mu \mathrm{g} / \mathrm{L})\end{array}$ & $\begin{array}{c}\text { Ammonia } \\
\text { as nitrogen } \\
(\mathrm{mg} / \mathrm{L})\end{array}$ & $\begin{array}{l}\text { Nitrite plus } \\
\text { nitrate as } \\
\text { nitrogen } \\
\text { (mg/L) }\end{array}$ & $\begin{array}{c}\text { Nitrite as } \\
\text { nitrogen } \\
\text { (mg/L) }\end{array}$ & $\begin{array}{c}\text { Total } \\
\text { nitrogen } \\
\text { (mg/L) }\end{array}$ & $\begin{array}{c}\text { Ortho- } \\
\text { phosphate } \\
\text { (mg/L) }\end{array}$ & $\begin{array}{c}\text { H2-H1 } \\
\text { ratio } \\
\text { (per mil) }\end{array}$ & $\begin{array}{c}\text { 018-016 } \\
\text { ratio } \\
\text { (per mil) }\end{array}$ \\
\hline ET-2A, 7/16/07 & 1.5 & 0.02 & 4.5 & 0.002 & 4.62 & 0.021 & -102 & -13.12 \\
\hline ET-2B, 7/16/07 & 1.1 & 0.02 & 4.56 & 0.002 & 4.71 & 0.021 & -102 & -13.21 \\
\hline Relative \% Difference & 30.8 & 0.0 & 1.3 & 0.0 & 1.9 & 0.0 & 0.0 & 0.7 \\
\hline WT-12A, 7/19/07 & 1.8 & 0.02 & 6.26 & 0.002 & 6.59 & 0.045 & -102 & -13.33 \\
\hline WT-12B, 7/19/07 & 0.8 & 0.02 & 6.23 & 0.002 & 6.51 & 0.045 & -102 & -13.31 \\
\hline Relative \% Difference & 80.2 & 0.0 & 0.5 & 0.0 & 1.2 & $\mathbf{0 . 0}$ & 0.0 & 0.2 \\
\hline WT-4A, 7/24/07 & 7.3 & $0.013 \mathrm{E}$ & 7.26 & $0.001 \mathrm{E}$ & 7.63 & 0.013 & -101 & -13.2 \\
\hline WT-4B, 7/24/07 & 2.9 & 0.011 & 7.32 & 0.001 & 7.62 & 0.014 & -101 & -13.25 \\
\hline Relative \% Difference & 86.3 & 16.7 & 0.8 & $\mathbf{0 . 0}$ & 0.1 & 7.4 & 0.0 & 0.4 \\
\hline Average & 65.7 & 5.6 & 0.9 & 0.0 & 1.1 & 2.5 & 0.0 & 0.4 \\
\hline Minimum & 30.8 & 0.0 & 0.5 & 0.0 & 0.1 & 0.0 & 0.0 & 0.2 \\
\hline Maximum & 86.3 & 16.7 & 1.3 & 0.0 & 1.9 & 7.4 & 0.0 & 0.7 \\
\hline
\end{tabular}


Table 2-5. Analytical quality-assurance and quality- control data for surface-water sample spikes, Toll Gate Creek, July-August 2007.

[Sample ID, synoptic-sample identification number; mg/L, milligramsper liter; $\mu \mathrm{g} / \mathrm{L}$, micrograms per liter; Most probable values and F-pseudosigma for sample T-147 provided by Farrar (1997), F-pseudosigma is equivalent to the standard deviation of traditional statistics when the data have a Gaussian distribution; na, not applicable]

\begin{tabular}{|c|c|c|c|c|c|c|c|c|c|c|c|c|}
\hline Sample ID & $\begin{array}{c}\text { Aluminum, } \\
\text { filtered } \\
(\mu \mathrm{g} / \mathrm{L})\end{array}$ & $\begin{array}{c}\text { Calcium, } \\
\text { filtered } \\
\text { (mg/L) }\end{array}$ & $\begin{array}{c}\text { Iron, } \\
\text { filtered } \\
\text { ( } \mu \mathrm{g} / \mathrm{L})\end{array}$ & $\begin{array}{c}\text { Magnesium, } \\
\text { filtered } \\
(\mathrm{mg} / \mathrm{L})\end{array}$ & $\begin{array}{c}\text { Manganese, } \\
\text { filtered } \\
\text { ( } \mathrm{gg} / \mathrm{L})\end{array}$ & $\begin{array}{l}\text { Sodium, } \\
\text { filtered } \\
\text { (mg/L) }\end{array}$ & $\begin{array}{c}\text { Selenium, } \\
\text { filtered } \\
(\mu \mathrm{g} / \mathrm{L})\end{array}$ & $\begin{array}{c}\text { Silica, } \\
\text { filtered } \\
(\mathrm{mg} / \mathrm{L})\end{array}$ & $\begin{array}{c}\text { Uranium, } \\
\text { filtered } \\
\text { ( } \mu \mathrm{g} / \mathrm{L})\end{array}$ & $\begin{array}{c}\text { Zinc, } \\
\text { filtered } \\
(\mu \mathrm{g} / \mathrm{L})\end{array}$ & $\begin{array}{l}\text { Bromide } \\
\text { spike } \\
\text { (mg/L) }\end{array}$ & $\begin{array}{c}\text { Sulfate } \\
\text { spike } \\
\text { (mg/L) }\end{array}$ \\
\hline Most probable value & 14.0 & 41.1 & 8.4 & 8.20 & 17.2 & 52.6 & 10.1 & 24.0 & 3.21 & 14.0 & na & na \\
\hline F-pseudosigma & 7.5 & 1.7 & 6.4 & 0.30 & 1.4 & 2.2 & 1.8 & 1.4 & 0.59 & 2.2 & na & na \\
\hline T-147 at TG-9971 & 15.3 & 38.7 & 7.0 & 7.77 & 15.2 & 53.0 & 11.4 & 23.0 & 3.00 & 14.6 & 1 & na \\
\hline T-147 at TG-10993 & 18.8 & 38.6 & 7.0 & 7.78 & 15.2 & 53.7 & 10.5 & 23.0 & 2.93 & 12.8 & 3 & na \\
\hline T-147 at TG-11312 & 13.9 & 38.3 & 7.0 & 7.71 & 15.3 & 53.8 & 11.2 & 22.8 & 2.94 & 13.2 & 5 & na \\
\hline T-147 at TG-9673 & 15.7 & 38.4 & 9.0 & 7.69 & 14.7 & 519 & 10.8 & 22.1 & 3.00 & 11.4 & 1 & 1,000 \\
\hline T-147 at TG-4361 & 25.4 & 38.7 & 13 & 7.79 & 15.3 & 53.2 & 10.8 & 23.1 & 2.94 & 13.1 & 1 & na \\
\hline T-147 at TG-5075 & 19.4 & 39.4 & 8.0 & 7.91 & 15.4 & 54.5 & 11.4 & 22.8 & 3.02 & 13.5 & 3 & na \\
\hline T-147 at TG-6531 & 20.0 & 38.0 & 8.0 & 7.63 & 15.0 & 53.1 & 10.9 & 22.7 & 2.92 & 12.8 & 5 & na \\
\hline T-147 at TG-7447 & 15.6 & 39.4 & 8.0 & 7.90 & 14.8 & 494 & 10.7 & 22.2 & 3.07 & 11.7 & 1 & 1,000 \\
\hline T-147 at TG-1997 & 25.6 & 38.8 & 10 & 7.79 & 15.4 & 52.9 & 11.4 & 23.1 & 2.94 & 13.4 & 1 & na \\
\hline T-147 at TG-2893 & 14.3 & 38.6 & 8.0 & 7.75 & 15.2 & 53.4 & 11.3 & 22.9 & 2.94 & 12.8 & 3 & na \\
\hline T-147 at TG-3466 & 20.0 & 38.3 & 8.0 & 7.70 & 15.2 & 53.6 & 10.9 & 22.7 & 2.93 & 12.8 & 5 & na \\
\hline T-147 at TG-3897 & 13.6 & 38.9 & 8.0 & 7.77 & 14.8 & 500 & 10.8 & 22.1 & 2.85 & 10.9 & 1 & 1,000 \\
\hline T-147 at TG-371 & 13.3 & 39.0 & 7.0 & 7.83 & 15.4 & 53.1 & 11.5 & 23.1 & 2.91 & 12.8 & na & na \\
\hline
\end{tabular}



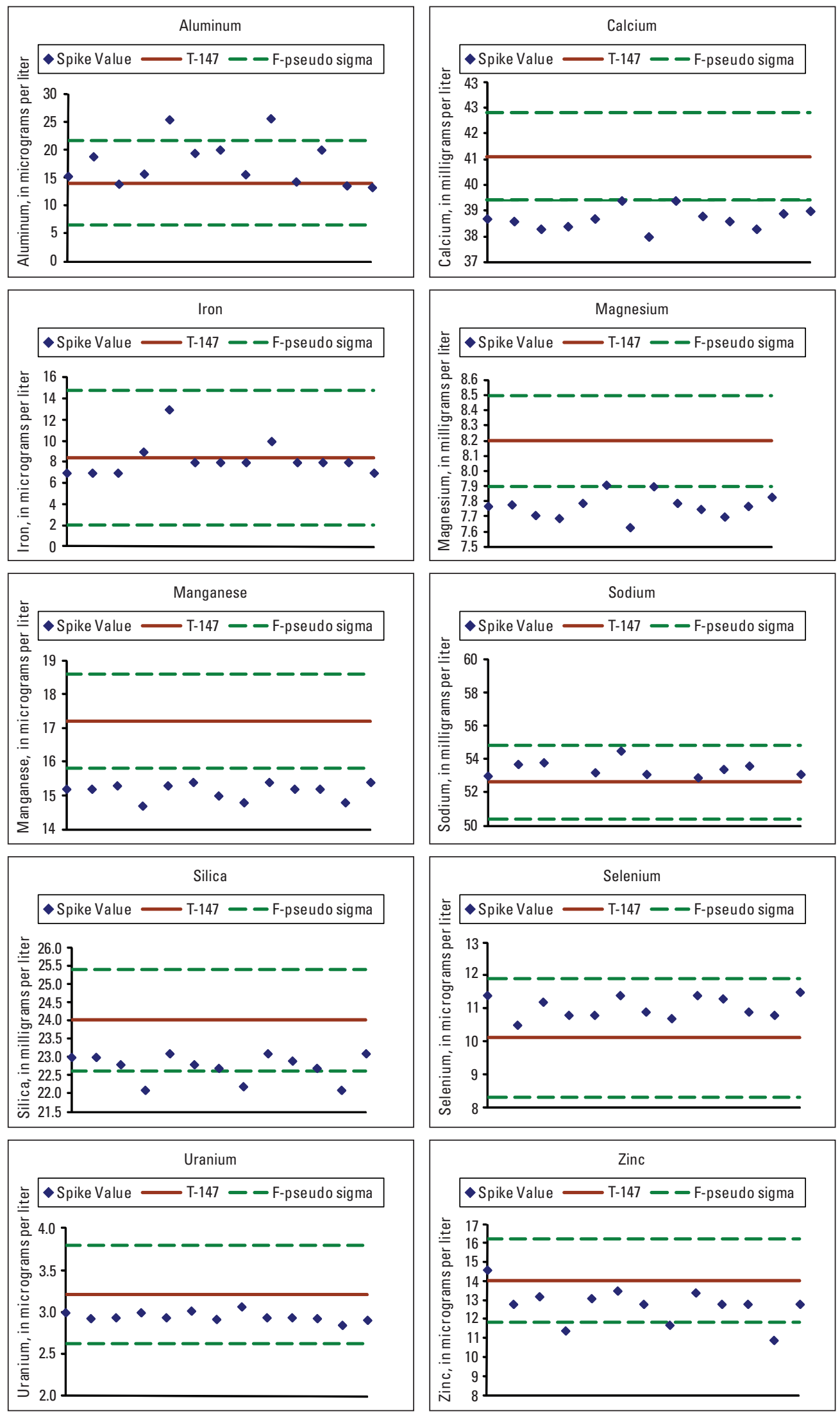

Figure 2-1. Graphs showing spiked-standard concentrations for surface-water samples, Toll Gate Creek, July-August 2007. 
below the acceptable range. The concentrations in T-147 were below the minimum concentrations for calcium and magnesium in environmental samples but within the range of environmental sample concentrations for manganese (table 2-2). In addition, the charge balances for all environmental samples were within \pm 4 percent indicating that any low bias for calcium and magnesium concentrations was not significant enough to affect the charge-balance calculation and is thus considered negligible. The low bias of manganese data is not critical to the interpretations presented herein, but the results are described for those who might use the data for other purposes.

Comparison of total-recoverable (unfiltered) to filtered concentrations of calcium, magnesium, sodium, iron, manganese, aluminum, selenium, zinc, and uranium was used to reveal bias in the dataset. In general, total-recoverable constituent concentrations are expected to be equal to or greater than filtered concentrations owing to the potential presence of particulate matter. For sodium and selenium, the filtered concentrations were consistently greater than the total-recoverable concentration (up to 35 percent greater), which indicates bias in the results. The analyzing laboratory (NWQL) indicated the bias may have been caused by the different analytical instruments and (or) laboratory processing procedures used for total-recoverable and filtered concentrations. Total-recoverable and filtered concentrations were analyzed using different inductively coupled plasmacollision cell mass spectrophotometers. In addition, samples for total-recoverable concentrations were processed prior to analysis to dissolve particulate matter by the addition of acid, heating, cooling, and then filtering. This processing may not have sufficiently dissolved constituents from particulates or retained them in solution throughout the analysis (Gary Cottrell, U.S. Geological Survey, oral commun., 2008). Because total-recoverable sodium concentrations were not critical to interpretations presented herein, the bias is not critical to the results of this study. For selenium, the analysis of filtered selenium in standard reference materials was acceptable (as described in the previous paragraph), and filtered selenium analyses were used for all calculations and interpretations presented herein. Bias in the total-recoverable selenium concentrations is attributed to laboratory methods, and because the analytical issues could not be completely resolved, the unfiltered selenium analyses were excluded from this dataset. In summary, results of analyses of T-147 spike samples indicate low bias and no interference from bromide concentrations up to $5 \mathrm{mg} / \mathrm{L}$ and sulfate concentrations up to $1,000 \mathrm{mg} / \mathrm{L}$ for iron, sodium, selenium, and uranium. Sulfate concentrations greater than $1,000 \mathrm{mg} / \mathrm{L}$ may cause low bias in silica and zinc analyses. Two samples showed a higher than acceptable bias for aluminum, which is consistent with aluminum issues of unknown origin that were also identified in blank and replicate samples, but that do not affect the interpretations in this report. Analyses of T-147 samples indicated a low bias for calcium and magnesium analyses. However environmental samples all had higher concentrations than T-147 and charge balance for all environmental samples fell within acceptable limits. Therefore, the bias is insignificant at concentrations measured in environmental samples. There was also an unexplained low bias in manganese concentrations that does not affect the interpretations of this study. Finally, negative bias in the concentrations of unfiltered relative to filtered selenium was likely caused by differences in the analytical techniques and instrumentation used for the analyses. Filtered selenium analyses were used for all calculations and interpretations presented herein because they did not show appreciable bias. Bias in the total-recoverable selenium concentrations is attributed to laboratory methods, and because the analytical issues could not be complete resolved, the unfiltered selenium analyses were excluded from this dataset. 


\section{Appendix 3. Concentration and Loading Profiles for Constituents of Interest other than Selenium}

This appendix presents graphs (fig. 3-1 through 3-6) of concentration and instream load compared to distance downstream from Quincy Reservoir for sodium, sulfate, and uranium, which had strong correlation with selenium (see "Correlation among Chemical Constituents" in main body of the report). Although selenium and nitrate also were correlated, a plot of nitrate concentration and load is not included because of insufficient spatial resolution relative to the other constituents.

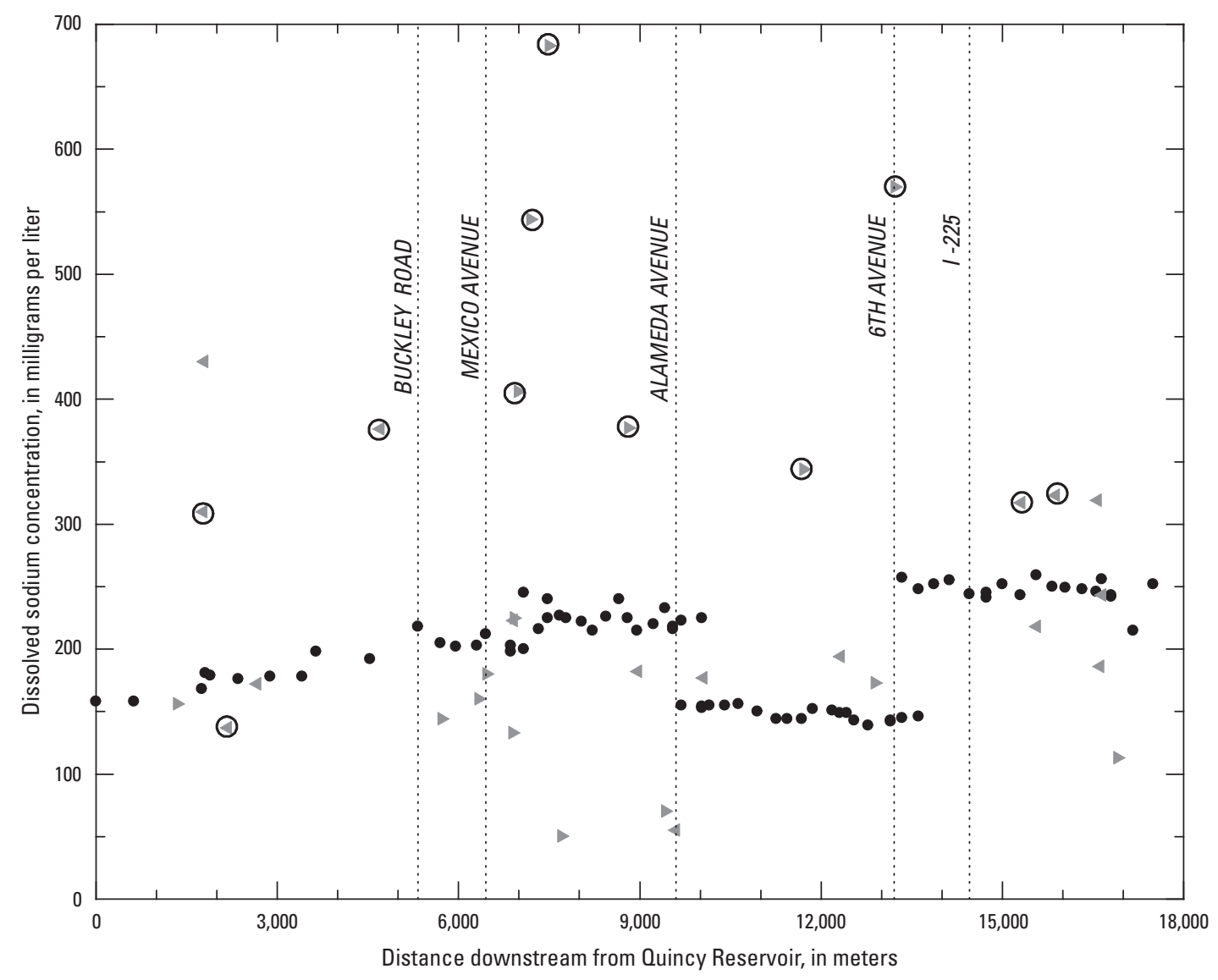

EXPLANATION

\footnotetext{
- Stream sites

Left-bank inflows

$\varangle$ Right-bank inflows

11 inflows having selenium concentration greater than 21 micrograms per liter
}

Figure 3-1. Graph showing dissolved sodium concentrations for stream and inflow samples compared to distance downstream from Quincy Reservoir, Toll Gate Creek, July-August 2007. 


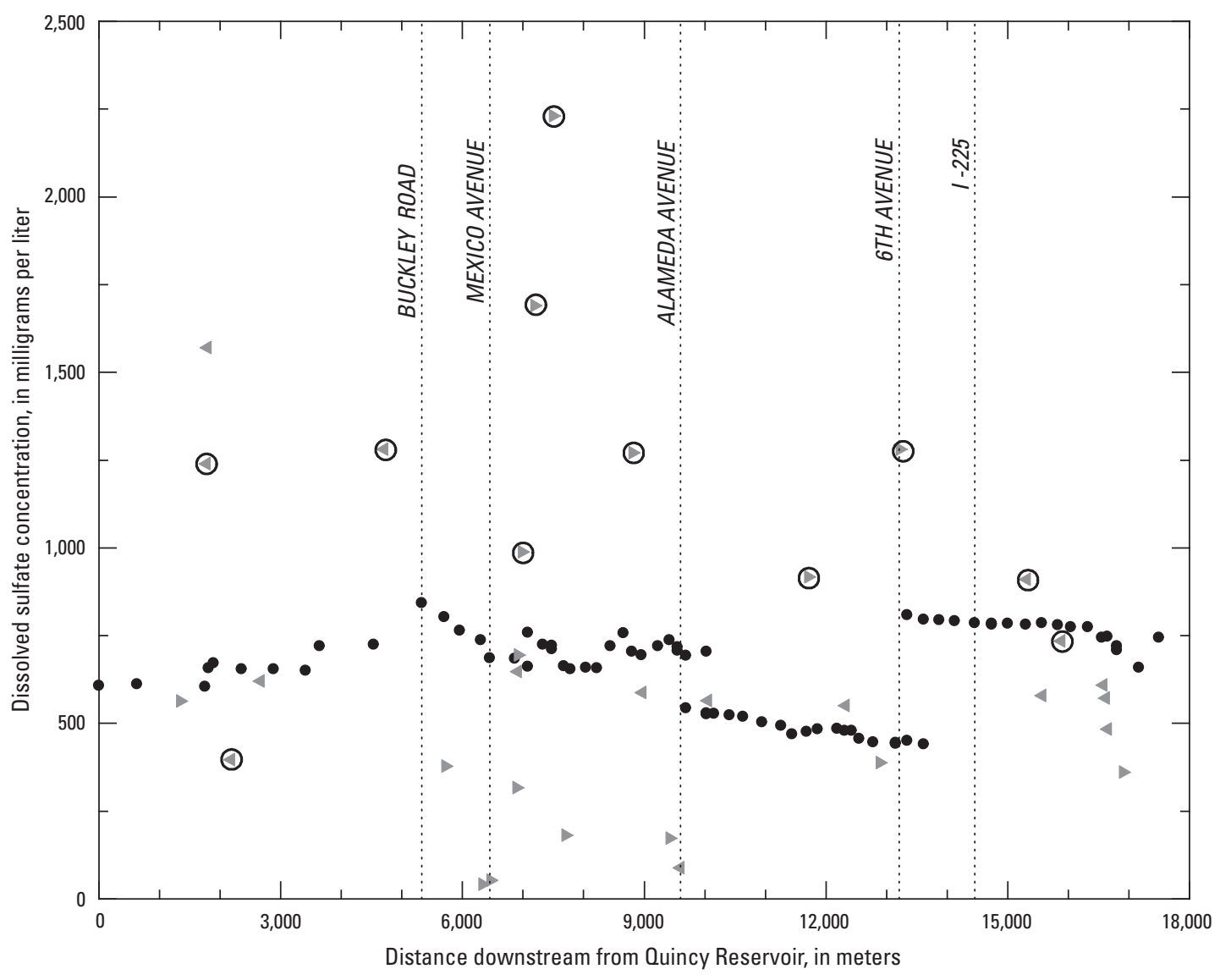

\section{EXPLANATION}

- Stream sites

- Left-bank inflows

$\triangleleft$ Right-bank inflows

O 11 inflows having selenium concentration greater than 21 micrograms per liter

Figure 3-2. Graph showing dissolved sulfate concentrations for stream and inflow samples compared to distance downstream from Quincy Reservoir, Toll Gate Creek, July-August 2007. 


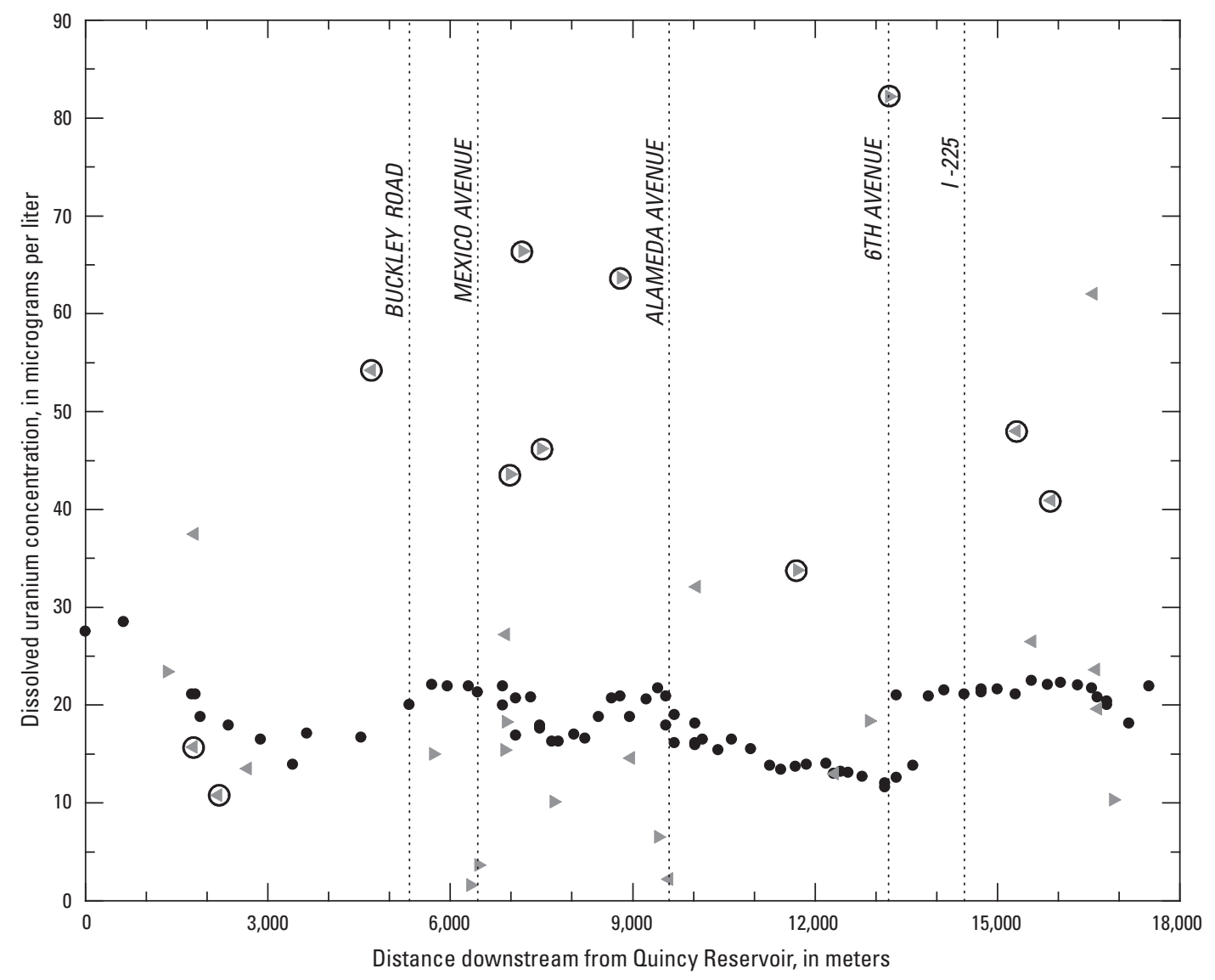

EXPLANATION

- Stream sites

- Left-bank inflows

$\checkmark$ Right-bank inflows

11 inflows having selenium concentration greater than 21 micrograms per liter

Figure 3-3. Graph showing dissolved uranium concentrations for stream and inflow samples compared to distance downstream from Quincy Reservoir, Toll Gate Creek, July-August 2007. 


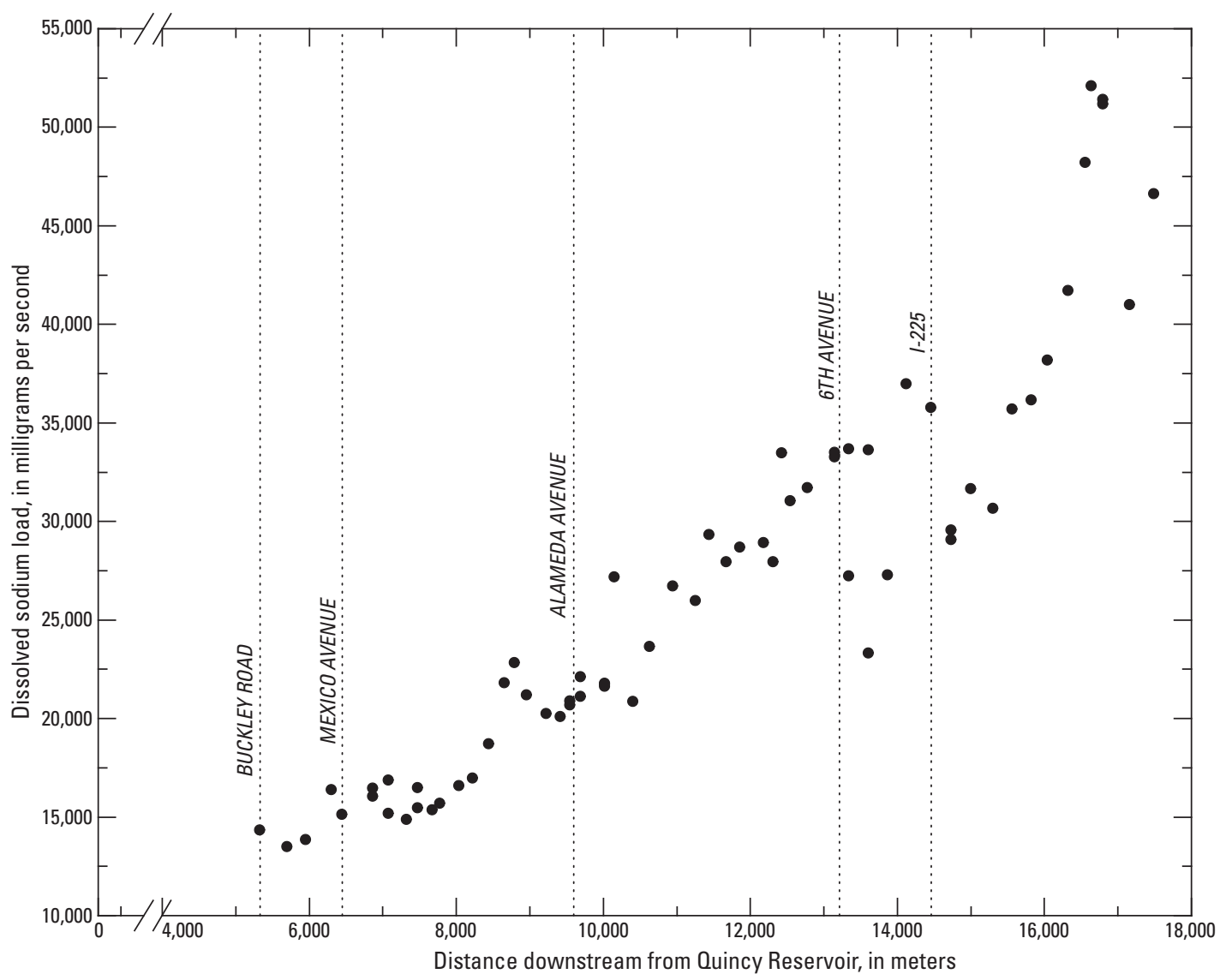

Figure 3-4. Graph showing dissolved sodium stream load compared to distance downstream from Quincy Reservoir, Toll Gate Creek, July-August 2007. 


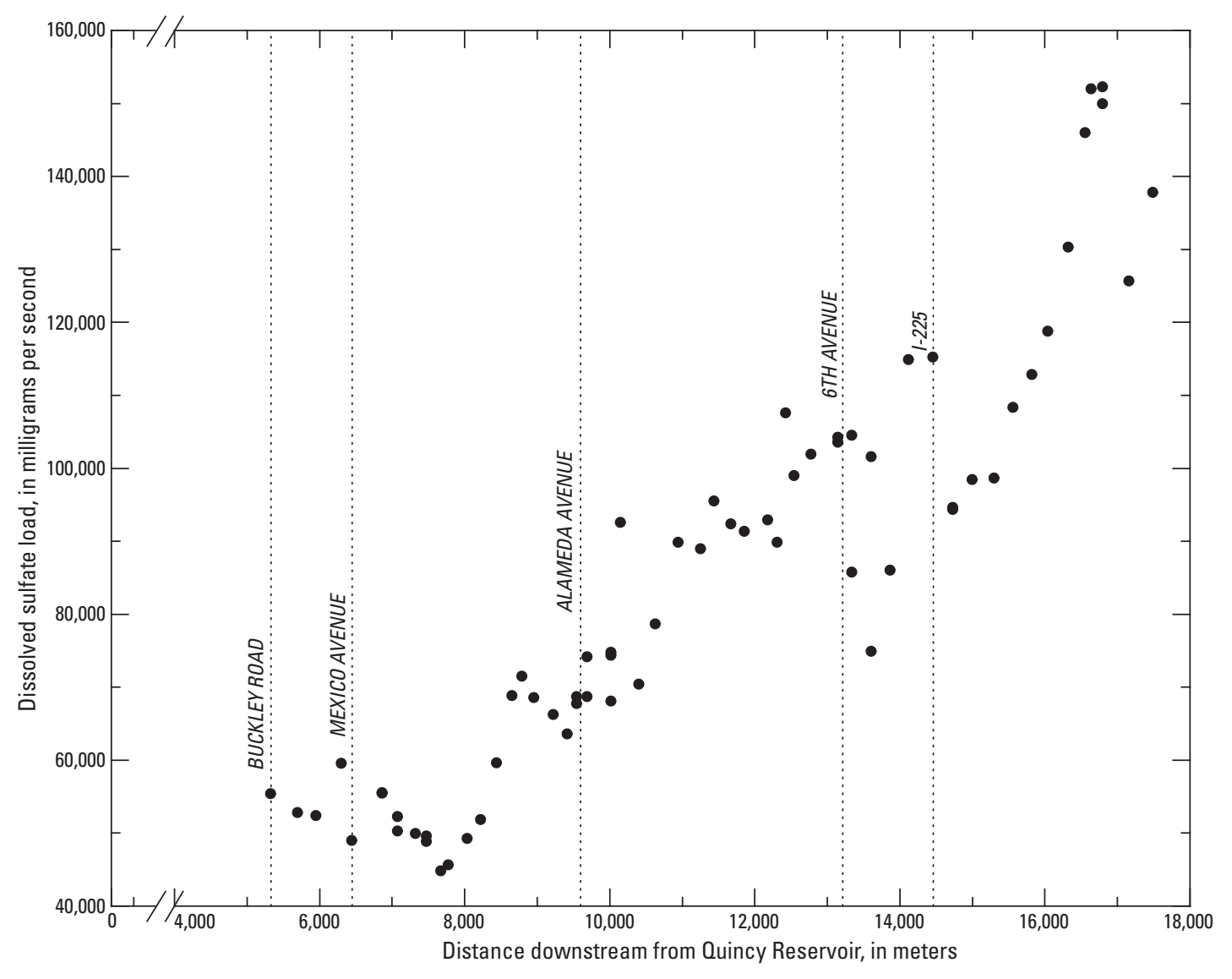

Figure 3-5. Graph showing dissolved sulfate stream load compared to distance downstream from Quincy Reservoir, Toll Gate Creek, July-August 2007. 


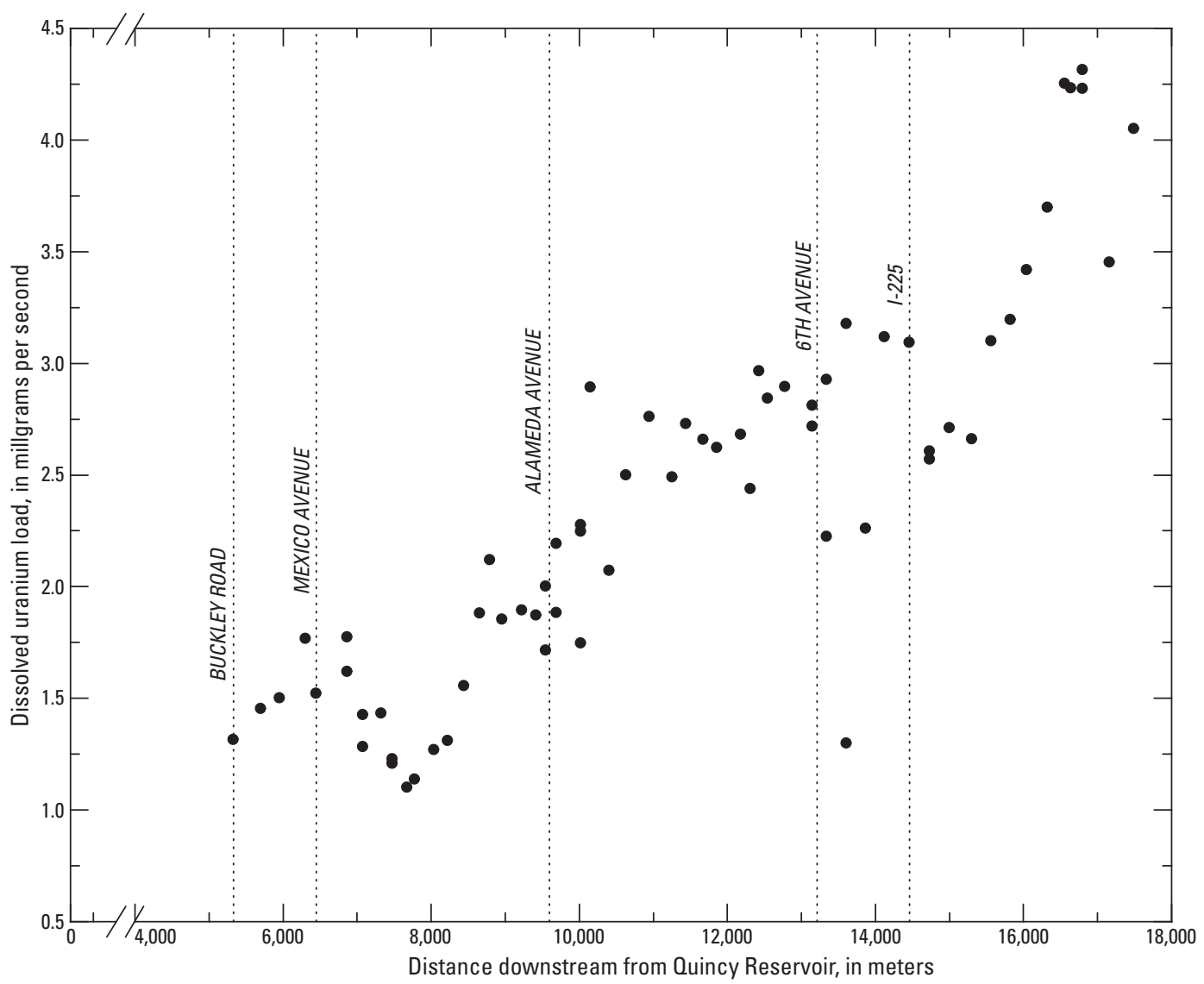

Figure 3-6. Graph showing dissolved uranium stream load compared to distance downstream from Quincy Reservoir, Toll Gate Creek, July-August 2007. 


\section{Appendix 4. Calculations of Evaporative Concentration and Loss}

This appendix presents evaporative concentration calculations from oxygen-isotope ratios for groundwater, inflow, and stream samples (table 4-1). Calculation methods are described in the "Hydrogen- and Oxygen-Isotope Ratios as Indicators of Evaporation" section in main body of the report.

Table 4-1. Evaporative concentration calculations from oxygen-isotope ratios for groundwater, inflow, and stream samples, Toll Gate Creek, July-August 2007.

\begin{tabular}{|c|c|c|c|c|c|c|}
\hline Site name & $\begin{array}{l}\text { Oxygen } \\
\text { isotope } \\
\text { enrichment } \\
\text { compared to } \\
\text { precipitation, } \\
\text { in per mil }\end{array}$ & $\begin{array}{c}\text { Equilibrium } \\
\text { enrichment } \\
\text { factor, } \\
\text { in per mil }\end{array}$ & $\begin{array}{c}\text { Kinetic } \\
\text { enrichment } \\
\text { factor, } \\
\text { in per mil }\end{array}$ & $\begin{array}{l}\text { Sum of equilibrium } \\
\text { and kinetic } \\
\text { enrichment factors, } \\
\text { in per mil }\end{array}$ & $\begin{array}{l}\text { Residual } \\
\text { water } \\
\text { fraction, } \\
\text { in percent }\end{array}$ & $\begin{array}{c}\text { Evaporative } \\
\text { loss, } \\
\text { in percent }\end{array}$ \\
\hline \multicolumn{7}{|c|}{ Groundwater samples } \\
\hline ET-1 & 2.84 & -10.60 & -2.13 & -12.73 & 80.0 & 20.0 \\
\hline ET-2 (A) & 2.87 & -10.60 & -2.13 & -12.73 & 79.8 & 20.2 \\
\hline $\mathrm{MC}-2 \mathrm{~b}$ & 3.18 & -10.60 & -2.13 & -12.73 & 77.9 & 22.1 \\
\hline SC-4 & 2.46 & -10.60 & -2.13 & -12.73 & 82.4 & 17.6 \\
\hline SC-6 & 3.27 & -10.60 & -2.13 & -12.73 & 77.3 & 22.7 \\
\hline SCTC-5 (A) & 2.99 & -10.60 & -2.13 & -12.73 & 79.1 & 20.9 \\
\hline TC-1 & 2.79 & -10.60 & -2.13 & -12.73 & 80.3 & 19.7 \\
\hline TC-2 & 2.81 & -10.60 & -2.13 & -12.73 & 80.2 & 19.8 \\
\hline URLUS-18 & 3.26 & -10.60 & -2.13 & -12.73 & 77.4 & 22.6 \\
\hline URLUS-28 & 3.18 & -10.60 & -2.13 & -12.73 & 77.9 & 22.1 \\
\hline URLUS-30 & 5.64 & -10.60 & -2.13 & -12.73 & 64.2 & 35.8 \\
\hline WT-1 & 2.9 & -10.60 & -2.13 & -12.73 & 79.6 & 20.4 \\
\hline WT-11 & 3.06 & -10.60 & -2.13 & -12.73 & 78.6 & 21.4 \\
\hline WT-12 (A) & 2.66 & -10.60 & -2.13 & -12.73 & 81.1 & 18.9 \\
\hline WT-14 & 3.45 & -10.60 & -2.13 & -12.73 & 76.3 & 23.7 \\
\hline WT-19 & 3.61 & -10.60 & -2.13 & -12.73 & 75.3 & 24.7 \\
\hline WT-2 & 2.84 & -10.60 & -2.13 & -12.73 & 80.0 & 20.0 \\
\hline WT-4 (A) & 2.79 & -10.60 & -2.13 & -12.73 & 80.3 & 19.7 \\
\hline WT-8 & 2.96 & -10.60 & -2.13 & -12.73 & 79.3 & 20.7 \\
\hline Minimum & & & & & 64.2 & 17.6 \\
\hline Maximum & & & & & 82.4 & 35.8 \\
\hline Range & & & & & 18.2 & 18.2 \\
\hline \multicolumn{7}{|c|}{ Inflow samples } \\
\hline TG-1001 & 7.60 & -10.60 & -2.13 & -12.73 & 55.0 & 45.0 \\
\hline TG-1129 & 6.88 & -10.60 & -2.13 & -12.73 & 58.2 & 41.8 \\
\hline TG-1859 & 3.10 & -10.60 & -2.13 & -12.73 & 78.4 & 21.6 \\
\hline TG-2165 & 3.00 & -10.60 & -2.13 & -12.73 & 79.0 & 21.0 \\
\hline TG-3479 & 3.71 & -10.60 & -2.13 & -12.73 & 74.7 & 25.3 \\
\hline TG-6373 & 4.34 & -10.60 & -2.13 & -12.73 & 71.1 & 28.9 \\
\hline TG-11570 & 8.37 & -10.60 & -2.13 & -12.73 & 51.8 & 48.2 \\
\hline
\end{tabular}


Table 4-1. Evaporative concentration calculations from oxygen-isotope ratios for groundwater, inflow, and stream samples, Toll Gate Creek, July-August 2007.-Continued

\begin{tabular}{|c|c|c|c|c|c|c|}
\hline Site name & $\begin{array}{c}\text { Oxygen } \\
\text { isotope } \\
\text { enrichment } \\
\text { compared to } \\
\text { precipitation, } \\
\text { in per mil }\end{array}$ & $\begin{array}{c}\text { Equilibrium } \\
\text { enrichment } \\
\text { factor, } \\
\text { in per mil }\end{array}$ & $\begin{array}{c}\text { Kinetic } \\
\text { enrichment } \\
\text { factor, } \\
\text { in per mil }\end{array}$ & $\begin{array}{l}\text { Sum of equilibrium } \\
\text { and kinetic } \\
\text { enrichment factors, } \\
\text { in per mil }\end{array}$ & $\begin{array}{c}\text { Residual } \\
\text { water } \\
\text { fraction, } \\
\text { in percent }\end{array}$ & $\begin{array}{c}\text { Evaporative } \\
\text { loss, } \\
\text { in percent }\end{array}$ \\
\hline TG-WP460 & 5.69 & -10.60 & -2.13 & -12.73 & 64.0 & 36.0 \\
\hline TG-4268 & 4.90 & -10.60 & -2.13 & -12.73 & 68.1 & 31.9 \\
\hline TG-6993 & 4.45 & -10.60 & -2.13 & -12.73 & 70.5 & 29.5 \\
\hline TG-9989 & 2.84 & -10.60 & -2.13 & -12.73 & 80.0 & 20.0 \\
\hline TG-10242 & 3.06 & -10.60 & -2.13 & -12.73 & 78.6 & 21.4 \\
\hline TG-10557 & 2.57 & -10.60 & -2.13 & -12.73 & 81.7 & 18.3 \\
\hline TG-11246 & 2.47 & -10.60 & -2.13 & -12.73 & 82.4 & 17.6 \\
\hline TG-11292 & 4.99 & -10.60 & -2.13 & -12.73 & 67.6 & 32.4 \\
\hline Minimum & & & & & 51.8 & 17.6 \\
\hline Maximum & & & & & 82.4 & 48.2 \\
\hline Range & & & & & 30.5 & 30.5 \\
\hline \multicolumn{7}{|c|}{ Stream samples } \\
\hline TG-WP451 & 5.84 & -10.60 & -2.13 & -12.73 & 63.2 & 36.8 \\
\hline TG-WP459 & 5.22 & -10.60 & -2.13 & -12.73 & 66.4 & 33.6 \\
\hline TG-WP462 & 5.23 & -10.60 & -2.13 & -12.73 & 66.3 & 33.7 \\
\hline TG-WP467 & 5.59 & -10.60 & -2.13 & -12.73 & 64.5 & 35.5 \\
\hline TG-WP472 & 6.55 & -10.60 & -2.13 & -12.73 & 59.8 & 40.2 \\
\hline TG-WP453B & 5.72 & -10.60 & -2.13 & -12.73 & 63.8 & 36.2 \\
\hline TG-0 & 5.74 & -10.60 & -2.13 & -12.73 & 63.7 & 36.3 \\
\hline TG-976 & 5.62 & -10.60 & -2.13 & -12.73 & 64.3 & 35.7 \\
\hline TG-1536 (A) & 6.03 & -10.60 & -2.13 & -12.73 & 62.3 & 37.7 \\
\hline TG-1536 (B) & 5.98 & -10.60 & -2.13 & -12.73 & 62.5 & 37.5 \\
\hline TG-1748 & 6.11 & -10.60 & -2.13 & -12.73 & 61.9 & 38.1 \\
\hline TG-1748 & 5.83 & -10.60 & -2.13 & -12.73 & 63.3 & 36.7 \\
\hline TG-2148 (A) & 5.9 & -10.60 & -2.13 & -12.73 & 62.9 & 37.1 \\
\hline TG-2148 (B) & 5.93 & -10.60 & -2.13 & -12.73 & 62.8 & 37.2 \\
\hline TG-2893 & 5.84 & -10.60 & -2.13 & -12.73 & 63.2 & 36.8 \\
\hline TG-3627 & 5.93 & -10.60 & -2.13 & -12.73 & 62.8 & 37.2 \\
\hline TG-3897 & 5.97 & -10.60 & -2.13 & -12.73 & 62.6 & 37.4 \\
\hline TG-4216 (A) & 6.23 & -10.60 & -2.13 & -12.73 & 61.3 & 38.7 \\
\hline TG-4216 (B) & 6.25 & -10.60 & -2.13 & -12.73 & 61.2 & 38.8 \\
\hline TG-4361 & 6.11 & -10.60 & -2.13 & -12.73 & 61.9 & 38.1 \\
\hline TG-4361 & 6.4 & -10.60 & -2.13 & -12.73 & 60.5 & 39.5 \\
\hline TG-5075 & 6.17 & -10.60 & -2.13 & -12.73 & 61.6 & 38.4 \\
\hline TG-6982 & 6.11 & -10.60 & -2.13 & -12.73 & 61.9 & 38.1 \\
\hline TG-7098 & 6.05 & -10.60 & -2.13 & -12.73 & 62.2 & 37.8 \\
\hline TG-7818 (A) & 6.07 & -10.60 & -2.13 & -12.73 & 62.1 & 37.9 \\
\hline TG-7818 (B) & 6.14 & -10.60 & -2.13 & -12.73 & 61.7 & 38.3 \\
\hline TG-8011 & 6.11 & -10.60 & -2.13 & -12.73 & 61.9 & 38.1 \\
\hline TG-8011 & 6.1 & -10.60 & -2.13 & -12.73 & 61.9 & 38.1 \\
\hline TG-9129 & 6.04 & -10.60 & -2.13 & -12.73 & 62.2 & 37.8 \\
\hline TG-9971 & 6.29 & -10.60 & -2.13 & -12.73 & 61.0 & 39.0 \\
\hline TG-10236 & 6.13 & -10.60 & -2.13 & -12.73 & 61.8 & 38.2 \\
\hline TG-10497 & 6.26 & -10.60 & -2.13 & -12.73 & 61.2 & 38.8 \\
\hline
\end{tabular}


Table 4-1. Evaporative concentration calculations from oxygen-isotope ratios for groundwater, inflow, and stream samples, Toll Gate Creek, July-August 2007.-Continued

\begin{tabular}{lcccccc}
\hline Site name & $\begin{array}{c}\text { Oxygen } \\
\text { isotope } \\
\text { enrichment } \\
\text { compared to } \\
\text { precipitation, } \\
\text { in per mil }\end{array}$ & $\begin{array}{c}\text { Equilibrium } \\
\text { enrichment } \\
\text { factor, } \\
\text { in per mil }\end{array}$ & $\begin{array}{c}\text { Kinetic } \\
\text { enrichment } \\
\text { factor, } \\
\text { in per mil }\end{array}$ & $\begin{array}{c}\text { Sum of equilibrium } \\
\text { and kinetic } \\
\text { enrichment factors, } \\
\text { in per mil }\end{array}$ & $\begin{array}{c}\text { Residual } \\
\text { water } \\
\text { fraction, } \\
\text { in percent }\end{array}$ & $\begin{array}{c}\text { Evaporative } \\
\text { loss, } \\
\text { in percent }\end{array}$ \\
\hline TG-11312 & 6.47 & -10.60 & -2.13 & -12.73 & 60.2 & 39.8 \\
TG-12164 & 6.39 & -10.60 & -2.13 & -12.73 & 60.5 & 39.5 \\
Minimum & & & & & 59.8 & 33.6 \\
Maximum & & & & & 66.4 & 40.2 \\
Range & & & & 6.6 & 6.6 \\
\hline
\end{tabular}

${ }^{1}$ Replicate sample. Final streamflow estimate is set equal to the average of the two tracer-dilution streamflow estimates. 


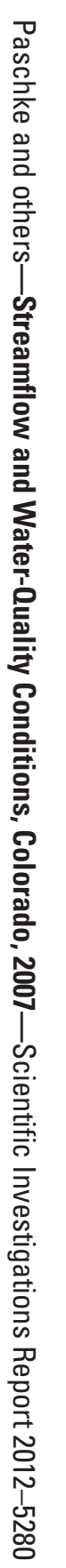

